\title{
Common Principles of European Intellectual Property Law
}

\author{
Edited by \\ ANSGAR OHLY
}

Geistiges Eigentum und

Wettbewerbsrecht

62

Mohr Siebeck 


\title{
Geistiges Eigentum und Wettbewerbsrecht
}

\author{
Herausgegeben von
}

Peter Heermann, Diethelm Klippel, Ansgar Ohly und Olaf Sosnitza

62

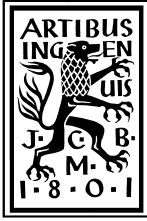





\section{Common Principles of European Intellectual Property Law}

Edited by

Ansgar Ohly

Mohr Siebeck 
ISBN 978-3-16-151826-3 eISBN 978-3-16-156656-1

ISSN 1860-7306 (Geistiges Eigentum und Wettbewerbsrecht)

The Deutsche Nationalbibliothek lists this publication in the Deutsche Nationalbibliographie; detailed bibliographic data is available on the Internet at $h t t p: / / d n b . d-n b . d e$.

(C) 2012 by Mohr Siebeck, P. O. Box 2040, D-72010 Tübingen.

This work is since 01/2020 licensed under the license "Attribution-NonCommercial-NoDerivatives 4.0 International" (CC BY-NC-ND 4.0). A complete version of the license text can be found at: https://creativecommons.org/licenses/by-nc-nd/4.0/. An electronic version of this book is freely available, thanks to the support of libraries working with Knowledge Unlatched. KU is a collaborative initiative designed to make high quality books Open Access for the public good. More information about the initiative can be found at www.knowledgeunlatched.org.

The book was set by Computersatz Staiger in Rottenburg/N., printed by Gulde-Druck in Tübingen on non-aging paper and bound by Gulde-Druck.

Printed in Germany. 


\section{Preface}

Intellectual property law has been harmonised by EU law to a considerable extent. At the same time intellectual property rights have converged. The academic discussion has not kept pace with this development. European intellectual property law is often seen through the spectacles of national law; panEuropean discussions about issues of Community law seem to be the exception rather than the rule. While intellectual property law has always been in the vanguard of EU harmonization, academic attempts to formulate common European principles and to suggest rules for areas as yet unaffected by harmonization are significantly less advanced that in general private law, where the work of various study groups has resulted in the Draft Common Frame of Reference.

Hence the steering group and the members of the Bayreuth DFG graduate school "Intellectual Property and the Public Domain" decided to invite some leading European scholars in this field to Bayreuth to enter into a discussion about common principles of European intellectual property law. This volume comprises the papers which were presented at the conference on 20 and 21 November 2009. Publication of this volume has taken embarrassingly long due to several obstacles. But all's well that ends well.

First and foremost I would like to thank all contributors to this volume, both for their contributions and for their patience with the slow editing process. My thanks also go to Daniela Simone for doing a thorough, yet speedy English language check (all remaining mistakes are the authors' and mine) and to all student assistants of my chair who helped me with my editorial work. I hope that this volume will give impulses to a process which has started, but which is still to gather momentum.

Bayreuth in December 2011

Ansgar Ohly 



\title{
Table of Contents
}

\author{
I. Starting Points
}

Ansgar Obly

Introduction: The Quest for Common Principles of European

Intellectual Property Law - Useful, Futile, Dangerous? . . . . . . . . . . 3

Gerhard Dannemann

The Working Method of the Acquis Group - A Model? . . . . . . . . . . . 15

II. Substantive Intellectual Property Law

Alberto Musso

Grounds of Protection:

How Far Does the Incentive Paradigm Carry? . . . . . . . . . . . . . 33

Annette Kur

Two Tiered Protection - Designs and Databases as Legislative Models? . . 99

Matthias Leistner

Common Principles of Secondary Liability? . . . . . . . . . . . . . 117

Jean-Luc Piotraut

Limitations and Exceptions: Towards a European "Fair Use” Doctrine?. . 147

Jens Schovsbo

The Exhaustion of Rights and Common Principles

of European Intellectual Property Law . . . . . . . . . . . . . . . . . . 169

Igor B. Nestoruk

Common Principles of European Intellectual Property Law:

a Polish Perspective 


\section{Enforcement and Fundamental Rights}

\section{Marcus Norrgaird}

The European Principles of Intellectual Property Enforcement:

Harmonisation through Communication? .................... 203

\section{Christophe Geiger}

Fundamental Rights as Common Principles of European

(and International) Intellectual Property Law

\section{Intellectual Property and Competition}

\section{Steven Anderman}

The Interface between Intellectual Property Rights and EU Competition Law ............................ 241

Dirk Visser

Misrepresentation and Misappropriation

Two Common Principles or Common 'Basic Moral Feelings'

of Intellectual Property and Unfair Competition Law ...

Vytantas Mizaras

The Relationship between Intellectual Property Rights, Protection against Unfair Competition and Unfair Commercial

Practices: A Lithuanian Perspective

List of Authors 
I. Starting Points 



\title{
Introduction: \\ The Quest for Common Principles of European Intellectual Property Law - Useful, Futile, Dangerous?
}

\author{
Ansgar Obly
}

\section{The Quest for Common Principles}

\section{A Fragmented Discourse about Harmonised Law}

In the historical development of intellectual property law, several eras can be distinguished: the age of privileges, the age of enlightenment, when the theoretical underpinnings of intellectual property law were devised and when the first IP statutes were drafted, and the late $19^{\text {th }}$ century, when intellectual property law received its modern structure. ${ }^{1}$ In Europe, the most recent decades, however, should probably be termed "the age of Europeanisation". EU directives have resulted in the harmonisation of the European law of registered trade marks, of design law and of the provisions on enforcement. While a full harmonisation of copyright law has not been achieved yet, several directives have approximated the law in important respects, and further harmonisation does not seem a utopian prospect. In patent law, the European Patent Convention, while not forcing the member states to change the laws, has practically resulted in a harmonisation of the conditions of grant.

At the same time, intellectual property rights are extending, overlapping and converging. ${ }^{2}$ Copyright in computer programs and software patents or design rights, three-dimensional marks and unfair competition protection of product shapes are examples in point. Often these rights are treated as strategically in-

${ }^{1}$ See Gieseke, Vom Privileg zum Urheberrecht (1995); Höffner, Geschichte und Wesen des Urheberrechts, Bd.1, (2010); Sherman and Bently, The Making of Modern Intellectual Property Law (1999), pp. 11 et seq., 61 et seq.

${ }^{2}$ See Derclaye and Leistner, Intellectual Property Overlaps - a European Perspective (2011); Kur, in: Schricker, Dreier, Kur (eds.), Geistiges Eigentum im Dienste der Innovation (2001), pp. 23 et seq.; for overlaps between copyright and other intellectual property rights see Quaedvlieg, in: Derclaye (ed.), Research Handbook on the Future of EU Copyright (2009), pp. 408 ff.; Obly, Areas of Overlap Between Trade Mark Rights, Copyright and Design Rights in German Law, GRUR Int. 2007, 704 et seq. 
terchangeable in business practice. Licensing agreements cut across the borders of distinct IP rights. This tendency is reflected in EU law. The provisions of the EC Enforcement Directive ${ }^{3}$ apply generally and indistinctly to all intellectual property rights. The Magill/IMS Health principles on the abuse of a dominant position by the denial of licences (Art. 102 TFEU) were developed by the ECJ (now CJEU) in copyright cases, ${ }^{4}$ but they equally apply to other areas of intellectual property law. ${ }^{5}$

Although research into intellectual property issues has become much more intense in the last decades, the academic discussion has not fully kept pace with these developments. First, both practitioners and researchers often still look at intellectual property law through the spectacles of national law. While everyone is aware that harmonised law must be interpreted in accordance with the underlying EU directives, national patterns of interpretation which predate harmonisation still govern the application of the law. Lawyers tend to treat judgments handed down by their own national supreme courts with more interest and respect than CJEU decisions. A supranational European discussion about common issues of policy or interpretation has started, ${ }^{6}$ but it is still impeded by language difficulties, by differences between publication traditions and by the fact that the Court of Justice does not cite legal literature.

Secondly, even within the European jurisdictions, a growing specialisation among academics and practitioners has caused the areas of intellectual property law to drift apart. Copyright specialists are more interested in media law than in patents and sometimes even "feel the sublimity of their subject impaired by its relationship with industrial property law" . Patent lawyers, who sometimes have an engineering or natural science background, tend to form a close-knit community, which is more interested in institutional issues and in the interaction between law, technology and markets than in other fields of intellectual property law. Trade mark law is more closely connected with unfair competition or trade practices law than with copyright or patents. As Alois Troller noted in his seminal treatise on intellectual property law:

${ }^{3}$ Directive 2004/48/EC of the European Parliament and of the Council of 29 April 2004 on the enforcement of intellectual property rights, OJ L 157 of 30 April 2004, corrected version: OJ L 195 of 2 June 2004, p. 16.

${ }^{4}$ ECJ, case C-241, 242/91, [1995] ECR I-743 - Magill; ECJ, case C-418/01, [2004] ECR I-5069-IMS Health.

5 As shown by the decision of the CFI (now the GC) in the Microsoft case, case T-201/04; [2007] ECR II-3601, where the court did not distinguish between the various intellectual property rights at stake.

6 This slightly polemic account has to be taken with a pinch of salt. It shall by no means belittle the achievements of the European research institutions and study groups in this field, see, for example, the European Copyright Code recently proposed by the Wittem Group, available online at www.copyrightcode.eu (last checked on 17 October 2011).

7 Troller, Immaterialgüterrecht, Vol. 1, 3rd ed. (1983), $\$ 8$ II (p. 102). 
"[ $\mathrm{t}]$ his professional specialisation can hardly be stopped. The practitioners working in this area will always strive to cultivate the field entrusted to them even better and to breed increasingly refined varieties." 8

Troller was not happy with this tendency. He thought that it was the task of intellectual property research "to master these centrifugal forces".

\section{The Example of European Private Law}

In intellectual property research, the interest in common principles which are European and which also apply horizontally to all intellectual property rights is much less developed that in general private law, where research into common European principles has reached a high level of sophistication. ${ }^{9}$ The Lando Principles, ${ }^{10}$ the drafts prepared by the Study Group on a European Civil Code ${ }^{11}$ and the Acquis Principles ${ }^{12}$ represent results of academic work. The latter have recently become the basis of the Draft Common Frame of Reference. ${ }^{13}$ If, following Ronald Dworkin, one distinguishes between rules, which can be applied, and principles, which are more general and which can only be balanced, ${ }^{14}$ European private law academics have moved beyond formulating general principles and have reached the point where they feel confident enough to come up with blueprints for a European Civil Code.

In intellectual property law, the conditions for a similar research project to succeed should even be better than in general private law. Already before the start of European harmonisation there were more similarities between the

8 Supra, note 7.

9 See the overview over the various initiatives given by Leible, Europäisches Privatrecht am Scheideweg, NJW 2008, 2558, 2560; Zimmermann, Textstufen in der modernen Entwicklung des europäischen Privatrechts, EuZW 2008, 319.

${ }_{10}$ Lando and Beale (eds.), Principles of European Contract Law Parts I and II. Prepared by the Commission on European Contract Law (1999); Lando, Clive, Prüm and Zimmermann (eds.), Principles of European Contract Law Part III (2003).

${ }^{11}$ Study Group on a European Civil Code (ed.), Principles of European Law (14 vols.) (2006 et seq.).

12 Research Group on the Existing EC Private Law (ed.), Contract I - Pre-contractual Obligations, Conclusion of Contract, Unfair Terms (2007); Contract II - General Provisions, Delivery of Goods, Package Travel and Payment Services (2009).

13 Study Group on a European Civil Code/Research Group on EC Private Law (eds.), Principles, Definitions and Model Rules of European Private Law, Draft Common Frame of Reference (6 Vols.) (2009); for a critical appraisal see Eidenmüller, Faust, Grigoleit, Jansen, Wagner and Zimmermann, The Common Frame of Reference for European Private Law Policy Choices and Codification Problems, (2008) 28 Ox JLSt 659; Jansen and Zimmermann, "A European civil code in all but name": discussing the nature and purposes of the draft common frame of reference, [2010] CLJ 98.

${ }^{14}$ Dworkin, Taking Rights Seriously (1977), pp. 22 et seq., see also Fikentscher, Methoden des Rechts, Vol. II (1975), pp. 81 et seq.; Esser, Grundsatz und Norm in der richterlichen Fortbildung des Privatrechts, 4th ed. (1990), pp. 52 et seq., 69 et seq., 183 et seq. 
patent, copyright and trade mark laws of the member states than between their contract or tort laws. While harmonisation in contract law has mainly focussed on consumer protection law, i.e. on a specific area, core areas of general intellectual property law have been harmonised. Nevertheless, nobody seems to have tried to draft European Principles of Intellectual Property Law yet.

\section{Rules or Principles?}

On the basis of Dworkin's distinction between rules and principles, the concept of "European principles" could be criticised as ambiguous. It can mean two different things.

On the one hand one could follow the example given by the research groups on European private law referred to above or the example of the American Law Institute's restatements and draft rules for areas not yet covered by the existing EU directives. Ultimately the result could be a draft European Intellectual Property Code, elaborated on the basis of the existing regulations and directives, of the CJEU case-law and of comparative law. This code would enhance the transparency of European intellectual property law while at the same time uncovering possible inconsistencies. ${ }^{15}$

If, however, the term "principles" is taken seriously, the task is different. It is not to draw up a map of the existing law but to identify the principles and policies which underlie EU law and which inform its application. Such a catalogue of principles would be more abstract than a set of directly applicable rules. In particular, many of these principles would be "horizontal" in that they would apply to several or all intellectual property rights.

Most contributors to this volume do not attempted to propose rules for further harmonisation, but stress the value of principles. In the area of conditions of protection there is little potential for horizontal rules. Since patents, trade marks and copyright protect different subject-matter and serve different purposes, the substantive requirements for protection differ as a matter of necessity. If a common denominator of these requirements can be identified at all, it will be very general. Principles, however, can provide orientation in at least one important respect, as Alberto Musso points out in his contribution: intellectual property rights interfere with the freedom of competition, hence they require justification. An important task for intellectual property research consists in collecting possible grounds of justification, such as the need for incentives, the protection of the creator's personality or the protection of market transparency,

15 See the draft German Intellectual Property Code recently presented by Abrens and Mc Guire: Modellgesetz für Geistiges Eigentum (2011) and Abrens, Brauchen wir einen Allgemeinen Teil der Rechte des Geistigen Eigentums?, GRUR 2006, 617, 620. Such a project would not need to start from scratch: recently a group of European copyright scholars known as the Wittem Group has proposed a draft European Copyright Code, see supra, note 6. 
in applying them to the various intellectual property rights ${ }^{16}$ and in resisting unprincipled extensions of protection. Matthias Leistner argues that the law of secondary liability would benefit from an accepted set of criteria, which could apply generally even despite differences between the doctrinal foundations of national liability regimes. While the rules on exhaustion in trade mark law and copyright law are slightly different and while a codified rule of exhaustion is missing in patent law, Jens Schovsbo points out that there are several European principles which govern exhaustion. In enforcement law, Art. 3 of the EU Enforcement Directive explicitly lays down guidelines such as the principle of proportionality, the importance of which is stressed by Marcus Norrgaird.

Principles have one advantage and one disadvantage. The advantage is that they are easier to agree upon than detailed rules. Who would doubt, for example, that the fundamental freedoms of communication, which Christophe Geiger discusses, deserve respect and protection. However, principles require balancing, thus they are inherently vague. When, for example, the CJEU in its recent case-law on Art. 5 (1) of the EU Trade Mark Directive, stresses that a trade mark will only infringed by a use which interferes with the protected functions of a mark, it adopts a principled approach which is nevertheless too vague to give sufficient normative guidance to the courts of the member states. ${ }^{17}$ Ultimately, the result of the balancing exercise may even lack a rational basis, as Dirk Visser points out when characterising the prevention of misrepresentation and of misappropriation as the two basic emotions underlying unfair competition law.

\section{Restating versus Policy-Making}

One possible way of drafting European principles is the restatement, generalisation and extension of existing EU rules. This method has been adopted by the Acquis Group, as Gerhard Dannemann explains in his contribution. The price to pay for this method is that it leaves little room for discussing and shaping policy. Existing rules have to be accepted as starting-points, even if they seem unacceptable from a policy point of view.

This academic self-restraint is difficult to achieve in an area like intellectual property law, where policy issues lurk behind every corner and where the legislative process often resembles a tug-of-war between various interest groups. Hence it does not come as a surprise that policy issues play an important role in many contributions to this volume. While Jean-Luc Piotraut and Christophe Geiger each adopt a principled approach to copyright law, they differ in

${ }^{16}$ Cf. the overviews over possible justifications given by Bently and Sherman, Intellectual Property, $3^{\text {rd }}$ ed (2008), pp. 3 et seq.; Hilty, Rationales for the Legal Protection of Intangible Goods and Cultural Heritage, 40 IIC 883 (2009).

17 See infra, II 1. 
their policy assumptions. Jean-Luc Piotraut rejects a broad fair use exception in copyright law and stresses the wisdom of the present system, in which the intellectual property right prevails unless carefully crafted exceptions apply. Christophe Geiger, on the other hand, points to the constitutional dimension of the balancing exercise between property and freedom of exception and argues in favour of a level playing-field.

\section{Useful, Futile, Dangerous?}

\section{Dangerous?}

Intellectual property law has not always benefited from European harmonisation. Critics feel that harmonisation has resulted in an ever-increasing level of protection, whereas the freedom of competition and the freedom of information have not sufficiently been taken into account. According to its recitals, the Directive on Copyright in the Information Society ${ }^{18}$ aims at a "high level of protection" and at a "rigorous, effective system for the protection of copyright and related rights" 19 whereas the need for a fair balance between the interests of authors, investors and users features much less prominently. ${ }^{20}$ In trade mark law, the policy underlying the protection of well-known marks against misappropriation has never been entirely clarified. Some member states already provided for such protection at the time of harmonisation, and this seems to have been a sufficient reason for adopting it into European law. The recent evaluation of the protection of databases has not yielded a conclusive result, nevertheless European intellectual property rights, once created, are there to stay. Given these developments, at least academics who are critical of an over-protection of intellectual creations will hesitate to advocate a further European harmonisation.

While this criticism does not aim at European principles but rather at the law-making by the EU institutions in general, a closer look at the case-law of the CJEU discloses some more specific dangers. In the legal reasoning of the Court, general principles play an important role. These principles, however, are often so vague that their application to individual cases is difficult to predict. ${ }^{21}$ What is more, the CJEU tends to treat dicta from earlier judgments as if they were statutory rules, without devoting much effort to analysing the earlier cases or to justifying the generalisation. Two examples may highlight these observations.

18 Directive 2001/29/EC of the European Parliament and of the Council of 22 May 2001 on the harmonisation of certain aspects of copyright and related rights in the information society, OJ L 167 of 22 June 2001, p. 10.

${ }_{19}$ Recitals 9, 11.

20 See Recital 31.

21 See the criticism by Dinwoodie, Trade Mark Harmonisation - National Courts and the European Court of Justice, (2010) 41 IIC 1. 
In its Infopaq judgment, the CJEU surprised the European copyright community by attempting to derive a European concept of "protected work" from the specific protection requirements which apply to computer programs, databases and photographs: the Infosoc directive applied "in relation to a subject-matter which is original in the sense that it is its author's own intellectual creation". ${ }^{22}$ Although the application of this threshold is eventually left to the member states, this reasoning is still methodologically doubtful, as the maxim "singularia non sunt extenda" militates against treating exceptions as a valid basis for generalisation. Soon afterwards, the CJEU already seemed to regard its proposition as a well-established principle. The Court held that the display of a graphic user interface on a screen did not constitute an expression of a computer program, but that it could be protected as a copyrightable work if it was its author's own individual creation. ${ }^{23}$ This is astonishing for two reasons. First, some legal systems provide for an exhaustive list of works which can attract copyright protection. ${ }^{24}$ Second, the concept of a work as "the author's own individual creation" was applied without further discussion. The sequence of these two cases shows the quick career of a dubious principle.

The other example is the theory of protected trade mark functions. According to Recital 11 of the Trade Mark Directive, the function of trade mark law is "in particular to guarantee the trade mark as an indication of origin". While there is broad consent about this proposition, the justification for trade mark protection beyond the guarantee of commercial origin is much more disputed. While European trade mark law explicitly grants protection against dilution and misappropriation to well-known marks, it seemed for a long time that the "absolute" protection provided by Art. 9 (1)(a) CTMR and Art. 5 (1)(a) TMD only protected the origin function of the mark. In L'Oréal v. Bellure, however, the CJEU held that "these functions include not only the essential function of the trade mark, which is to guarantee to consumers the origin of the goods or services, but also its other functions, in particular that of guaranteeing the quality of the goods or services in question and those of communication, investment or advertising". ${ }^{25}$ While this statement may be an accurate account of the economic functions of trade marks, the Court does not give reasons for its view that these functions deserve the absolute protection afforded by Art. 5 (1) (a) TMD and that they are protected independently of an interference with the

22 CJEU, case C-5/08, [2009] ECR I-6569, paras. 31 et seq. - Infopaq v. Danske Dagblades Forening; see the comments by Derclaye, Infopaq International A/S v Danske Dagblades Forening (C-5/08): wonderful or worrisome? The impact of the ECJ ruling in Infopaq on UK copyright law, [2010] EIPR 247, and Schulze, Schleichende Harmonisierung des urheberrechtlichen Werkbegriffs? - Anmerkung zu EuGH “Infopaq/DDF”, GRUR 2009, 1019 et seq.

23 CJEU, case C-393/09 (not yet in ECR), paras. 41, 45 et seq. - Bezpečnostní softwarová asociace $v$. Ministerstvo kultury.

24 This is the case in British law, see Bently and Sherman (supra, n. 16), p. 58.

25 CJEU, case C-487/08, [2009] ECR I-2009, 5226, para. 58 - L’Oréal v. Bellure. 
origin function. Subsequent trade mark judgments have shown that the "trade mark functions" resemble a black box: it is very difficult to predict when the CJEU will regard one of these functions as affected. ${ }^{26}$ Despite explicit criticism by the Commission and widespread unease with the "L'Oréal turn" in trade mark law, however, the Court has not given up its theory in its recent Interflora judgment. ${ }^{27}$

To sum up, the role of European principles in the case-law of the Court of Justice has not always been a happy one, to say the least. The principles discussed are the results of premature generalisation, and they are too vague to provide normative guidance to the national courts of the member states. In addition, national courts are in a better position to give substance to broad principles on a case-by-case basis, whereas, due to the limitations of the preliminary reference procedure, the CJEU cannot decide cases, and the net of precedents necessarily remains wide-meshed.

\section{Futile?}

As a European academic, one should not entertain too many illusions about the impact of scholarly work on the making and application of EU law. Whereas national courts, if to a different extent, take account of monographs, commentaries and articles, the CJEU does not cite academic work. Some AdvocatesGeneral do, but the practice is inconsistent. Too often the CJEU case-law is a self-referential system: the only sources which the Court of Justice cites on a regular basis are the relevant treaties, regulations or directives and passages taken from its own judgments.

But one should not give up all hope: general principles can provide guidelines for legislation. In particular they can offer a referential system on the basis of which comments on current issues of intellectual property law and policy will gain clarity and force.

\section{Useful?}

Despite of all these objections, there is a good case for starting a discussion about common European structures, principles and rules of intellectual property law.

First, one of the problems of European intellectual property law is that it is too often made without proper regard for the underlying principles. As pointed out above, one method of harmonisation has been the combination of the most

${ }^{26}$ Obly, Keyword Advertising or Why the ECJ's Functional Approach to Trade Mark Infringement Does Not Function, (2010) 41 IIC 879, 881.

${ }^{27}$ CJEU, case C-323/09 (not yet in ECR), para. 34 - Interflora v. Marks E Spencer. 
protective provisions to be found in national intellectual property laws. Lobbying by the relevant industries has had an important influence, and governments are too often driven by the wish to protect their own national economies. The search for the underlying principles may help to identify lobby-driven provisions which contradict basic assumptions of the intellectual property system. The EU directive on comparative advertising is an example in point. ${ }^{28} \mathrm{It}$ is based on the consideration that comparative advertising may provide consumers with useful information and that it should hence be allowed as long as it does not interfere with the interests of competitors more than necessary and proportionate to achieve this task. ${ }^{29}$ Art. $4(\mathrm{~g})$ of the Directive, which prohibits the presentation of goods as imitations or replicas, however, is incompatible with this purpose and with the principle of freedom of imitation, ${ }^{30}$ about which there seems to be a general consensus among European jurisdictions, despite all differences in detail. ${ }^{31}$ When the principle underlying the directive is unearthed and set in its intellectual property law context, it becomes clearer that Art. 4(g) is out of line with the more general ides of the directive.

Secondly, a discussion about general principles can contribute to a "Europeanisation" of legal doctrine. Harmonised law already provides a starting-point for a genuinely European discussion of fundamental issues of intellectual property law which may partly replace traditional comparative law in this area. Following the example given by the CJEU, academics should also look at EU law less through the glasses of national law. A discussion about principles helps to form a common European core of convictions. It may also disclose differences which still exist between the national approaches: a French or a Dutch lawyer will have views about general doctrines of misappropriation which differ from the prevailing view in England. But only a discussion about principles discloses where a European consensus exists, where there may be convergence and in which areas the prevailing differences militate against further harmonisation.

Finally, it makes sense to look for horizontal principles which apply to all intellectual property rights. ${ }^{32}$ An "intra-disciplinary" comparison between the different intellectual property rights can highlight inconsistencies which may

${ }^{28}$ Art. 4 of Directive 2006/114/EC of the European Parliament and of the Council of 12 December 2006 concerning misleading and comparative advertising (codified version), OJ L 376 of 27 December 2006, p. 21.

29 See Obly and Spence, The Law of Comparative Advertising (2000), pp. 57 et seq.

30 See Kur, Bently and Obly, Sweet Smells and a Sour Taste - The ECJ's L'Oréal decision, University of Cambridge Legal Studies Research Paper Series, paper 10/01, p. 5, available online at http://papers.ssrn.com/sol3/papers.cfm?abstract_id=1492032 (last visited on 15 Octo ber 2011).

${ }^{31}$ See Obly, The Freedom on Imitation and its Limits - a European Perspective, (2010) 41 IIC 506, 509.

32 This approach is also adopted by the contributors to Kur and Mizaras (eds.), The Structure of Intellectual Property Law: Can One Size Fit All? (2011). 
be the result of historical accident. At the same time, justified differences can be stressed. If there is common ground, judgments and academic analysis can be transferred and can contribute to the solution of problems.

\section{Potential Common Principles: An Introduction to the Following Chapters}

As mentioned above, the discussion about European principles of general private law is much more advanced than in the area of intellectual property law. In the following chapter, Gerhard Dannemann outlines the working method of the Acquis group. He describes the structure of the group and its methodology of generalising and extending existing rules of EU law.

At first sight, the grounds of protection differ fundamentally between the various intellectual property rights. However, the incentive paradigm, which is in particular stressed in law and economics research, might provide a common denominator. Alberto Musso warns us that it would be a misconception to grant absolute protection to all results of economic investments. While true creativity and innovation deserve strong protection, academics should resist the tendency of EU law to extend strong protection to trivial subject matter.

In some areas of intellectual property law, a two-tier system has emerged. This is most obvious in design law, where short-term protection is granted to unregistered designs whereas registered designs receive a broader and longer protection. Annette Kur examines whether this structure might be a model for other intellectual property rights. She argues that solutions in between fully fledged property rights and mere rules of conduct can enhance legal certainty and allow for a better balance between right holders' interests and the public domain. However, "in-between-solutions" have also resulted in an extension of intellectual property protection, to an allocation of property rights where mere rules of unfair competition might have been preferable.

One area where there is practical need for general and horizontal principles is the secondary liability of information service providers. The present law in this area, however, is confusingly diverse. Matthias Leistner draws out a matrix: national regimes differ, and at the same time several member states do not adopt a uniform approach to all intellectual property rights. Such complexity could be reduced by a set of principles which are flexible enough to cater for the different models of information service providing and which could also be adapted to different national regimes.

There are two drafting methods for exceptions and limitations. European law provides for an exhaustive list of specific exceptions whereas US copyright and trade mark law provide for a broad fair use exception which is highly flexible, but which may also result in legal certainty. Many European scholars find 
this model attractive. Jean-Luc Piotrant, however, argues in favour of a more cautious approach: "fair use" may conflict with the three-step test, and it does not necessarily lead to fairer results. Nevertheless, due to the challenges presented by new technologies courts should be allowed more flexibility when dealing with exceptions.

One exception which is common to all fields of intellectual property law is the principle of exhaustion. As Jens Schousbo demonstrates, there are several European principles behind this doctrine. First, in the EU the fundamental freedoms granted in the TFEU require exhaustion to be Community-wide. Secondly, the notion of consent, which at first sight seems to be determined by national contract law, must also be interpreted uniformly across the EU. A principled approach may even help to overcome the present schism between distribution of tangible goods, which is subject to exhaustion, and the distribution of data, where the application of the principle of exhaustion is highly disputed.

While intellectual property law is a part of civil law, it has gone its own, distinct way. As Igor B. Nestoruk explains, there were at one time plans in Poland to include copyright into the Civil Code, which, for sound reasons, have not been realised. Nevertheless the liability for torts committed on the internet still shows the close, if sometimes uneasy relationship between intellectual property and civil law.

Fundamental rights may have an important influence on intellectual property law. This has become evident in European enforcement law, as Marcus Norrgaird demonstrates. In the Promusicae case the CJEU had to balance the principle of effectiveness against the protection of privacy. Following the TRIPS Agreement, the Directive itself states relevant principles of enforcement law: effectiveness, proportionality and dissuasiveness. It would be a misunderstanding to unilaterally stress the need for effective protection.

In a more general sense, Christophe Geiger analyses the impact of constitutional law on intellectual property. Art. 17 of the EU Charter of Fundamental Rights guarantees the right of property and extends this guarantee to intellectual property. On the other hand, the right to property needs to be balanced against countervailing rights, in particular the right to free expression. Thus, Fundamental Rights should inform European principles of intellectual property law, and they can contribute to a fair balance between the interests of creators, investors and users.

One area in which both European principles and rules are already in place is competition law. Initially the relationship between intellectual property and competition law was seen as one of conflict, but Steven Anderman demonstrates that meanwhile both areas should be seen as complementary. Competition law principles are horizontal, as they apply equally to the various intellectual property rights. 
Competition law in the sense of antitrust law needs to be distinguished from unfair competition law, which has only partly been harmonized in the EU. The relationship between intellectual property and unfair competition law is disputed. While many authors think that unfair competition law should not fill gaps between intellectual property rights, Dirk Visser points out that the relationship is often not determined by rational construction, but rather by emotions. While in theory imitation outside the confines of intellectual property law may be acceptable, many judges feel that both misrepresentation and misappropriation are wrong and should be prevented.

The partial European harmonization of unfair competition law has added complexity to the picture. As Vytantas Mizaras demonstrates with respect to Lithuanian law, there is now not only the issue of how unfair competition law relates to intellectual property law; there is also an overlap between the harmonized provisions which apply to $\mathrm{B} 2 \mathrm{C}$ relations and the national rules concerning B2B unfair competition law. Thus there is also a need for general principles or even rules of unfair competition law in general. 


\title{
The Working Method of the Acquis Group - A Model?
}

\author{
Gerhard Dannemann
}

\section{Introduction}

\section{Acquis Group and Acquis Principles}

The European Research Group on Existing EC Private Law (known as the Acquis Group) was founded in 2002, and comprises some fifty scholars from some twenty EU member states. ${ }^{1}$ Its aim is to restate the existing EC private law in clearer and more coherent rules. These rules, which are called Acquis Principles (ACQP), are to serve as a source for the drafting, the transposition and the interpretation of European Community law. ${ }^{2}$

In 2004, the Acquis Group began drafting contract law rules based on the acquis communautaire, which consists of regulations, directives, ECJ decisions and also the incorporation practice of the member states. The Acquis Group published a first volume on contract law in $2007,{ }^{3}$ followed by a second volume in 2009. ${ }^{4}$ A third and final volume is expected for 2012. French, German, Italian, Polish and Japanese translations of the Acquis Principles have been, or are about to be, published.

The Acquis Group has embarked on a similar restatement of tort law. Intellectual property law is currently not on the Acquis Group's agenda. The present

${ }^{1}$ A full list of members and other information on the Acquis Group is available at http:// www.acquis-group.org.

2 Art. 1:101 ACQP: Scope and purpose of these Principles

(1) The following principles and rules are formulated on the basis of the existing law of the European Community in the field of contract law.

(2) These principles and rules serve as a source for the drafting, the transposition and the interpretation of European Community law.

(3) ...

${ }^{3}$ Research Group on Existing EC Private Law (Acquis Group), Principles of the Existing EC Contract Law (Acquis Principles), Contract I: Pre-Contractual Obligations, Conclusion of Contract, Unfair Terms, (2007). The Acquis Principles (without comments) are also available at www.acquis-group.org.

${ }^{4}$ Research Group on Existing EC Private Law (Acquis Group), Principles of the Existing EC Contract Law (Acquis Principles), Contract II: General Provisions, Devliery of Goods, Package Travel and Payment Services (2009). 
paper aims to explain the work and methodology which the Acquis Group has employed in its restatement of EC contract law. ${ }^{5}$ It will be left to the reader to decide whether these could be usefully employed in a restatement of European intellectual property law.

\section{Acquis Principles and the Draft Common Frame of Reference}

In 2005, the Acquis Group became a founding member of the Joint Network on European Private Law (CoPECL). ${ }^{6}$ Other members include the Study Group for a European Civil Code, ${ }^{7}$ the "Insurance Group", ${ }^{8}$ the Association Henri Capitant, " the "Common Core Group", ${ }^{10}$ the "Economic Impact Group", 11 the "Database Group" 12 and the Academy of European Law. ${ }^{13}$ The CoPECL network secured funding under the $6^{\text {th }}$ Framework Programme of the EC, which allowed the Acquis Group to pay for its meetings.

The CoPECL network has produced a draft for the so-called "Common Frame of Reference of European Contract Law". At the core, this draft (DCFR) consists of a compilation of rules, arranged much like a codification of the law of obligations, as the DCFR also contains rules on tort and unjust enrichment. These rules were drafted and compiled by the Study Group and the Acquis Group, whereas the other members of CoPECL have commented, contributed and assisted in various other ways. An outline edition of the DCFR, was published in early $2009^{14}$ and a six volume version with commentary appeared in October 2009. ${ }^{15}$

5 The present paper expands on Dannemann, Consolidating EC Contract Law: An Introduction to the Work of the Acquis Group, in: Acquis Group (ed.), Acquis Principles, Contract II (supra, note 4), xxxvi et seq. and on Dannemann/Ferreri/Graziadei, Consolidating EC Contract Law Terminology: The Contribution of the Terminology group, ibid., 1 et seq.

${ }^{6}$ http://www.copecl.org.

7 http://www.sgecc.net.

8 Project Group on a Restatement of European Insurance Contract Law, http://www. uibk.ac.at/zivilrecht/restatement/.

9 Association Henri Capitant des amis de la culture juridique française (http://www.hen ricapitant.org), together with the Société de Législation Comparée (http://www.legiscom pare.com) and the Conseil Supérieur du Notariat (http://www.notaires.fr/notaires/page/con seil-superieur-notariat?page_id=58).

10 The Common Core of European Private Law (http://www.common-core.org).

11 Research Group on the Economic Assessment of Contract Law Rules (Tilburg Law and Economics Center, http://www.tilburguniversity.nl/tilec/).

12 http://icd.recherche.jm.u-psud.fr.

13 Academy of European Law (ERA, http://www.era.int).

14 Principles, Definitions and Model Rules of European Private Law: Draft Common Frame of Reference (DCFR), Outline Edition, The Study Group on a European Civil Code and the Research Group on EC Private Law (Acquis Group), von Bar/Clive/Schulte-Nölke (eds.) (2009).

15 Principles, Definitions and Model Rules of European Private Law: Draft Common 
Within the DCFR, the Acquis Group has formulated all those rules which are based on existing EC contract law. These rules are largely identical to the corresponding Acquis Principles. As the Acquis Principles are merely intended to consolidate the acquis communautaire on contract law, they are methodologically clearly distinguished from the task of the Study Group, which has formulated desirable rules based on a comparative review of contract laws in Europe. ${ }^{16}$

The process by which the EC organs will adopt a Common Frame of Reference on European Contract Law is still under way. In 2010, the European Commission appointed a "Expert Group on a Common Frame of Reference in the area of European contract law". ${ }^{17}$ In May 2011 this expert group published a "Feasibility Study" on an European Contract Law, which is largely based on contract law rules contained in the DCFR. ${ }^{18}$ Nevertheless, there are several possible purposes which the CFR can serve.

a) One of them is the so-called "toolbox" function, initially the main aim of the European Commission. ${ }^{19}$ Under this approach, the CFR is to be used as "a non-binding set of fundamental principles, definitions and model rules to be used by the lawmakers at Union level to ensure greater coherence and quality in the lawmaking process". ${ }^{20}$

b) The above-mentioned Feasibility Study, reflecting a changed attitude within the Commission, is based on the assumption that the European Union will adopt an optional European contract law - optional in the sense that this law will only apply if chosen by the parties. This was an option which had continuously attracted the interest of the European Parliament and which is now pursued by the Commission's Proposal for a Regulation on a Common European Sales Law. ${ }^{21}$

c) A third, and particularly controversial, view sees the Common Frame of Reference as a basis which could be used for drafting a future European Civil Code, as evidenced by the name of the Study Group for a European Civil Code.

Of course it will matter in more than one way whether the Acquis Principles (or DCFR rules based on ACQP) will end up in a dustbin or in a European Civil Code or, perhaps most likely, will find some way into an Optional Instrument.

Frame of Reference (DCFR), The Study Group on a European Civil Code and the Research Group on EC Private Law (Acquis Group), von Bar/Clive/Schulte-Nölke (eds.) (2009).

16 See also below, II.

17 Commission Decision of 26 April 2010 (2010/233/EU).

18 A European contact law for consumers and businesses: Publication of the results of the feasibility study carried out by the Expert Group on European contract law for stakeholders' and legal practitioners' feedback, http://ec.europa.eu/justice/policies/consumer/docs/expla natory_note_results_feasibility_study_05_2011_en.pdf

${ }_{19} \mathrm{COM} / 2004 / 0651$ : “"toolbox, where appropriate, when presenting proposals to improve the quality and coherence of the existing acquis and future legal instruments in the area of contract law".

20 COM 2010/233/EU, at (4).

${ }^{21}$ COM (2011) 635 final. 
That ultimate fate has, fortunately, a rather limited impact on the formulation of the Acquis Principles. If the Acquis Group has succeeded in consolidating what already exists in terms of EC contract law into one largely coherent and consistent set of rules, it can indeed be used as "toolbox" for a revision of EC directives, the formulation of new directives; the formulation of Optional Instruments, or as a basis for drafting a European Civil Code. ${ }^{22}$ While the latter is not an ambition of the Acquis Group, it has recently published a proposal for a first chapter on subject matter, application and scope of such an Optional Instrument. ${ }^{23}$

\section{Methodology and the Process of Drafting}

Throughout the $20^{\text {th }}$ century, comparative law scholars have been engaged in law harmonization projects based on a comparative review of various domestic laws. Some of the milestones in the area of contract law include Ernst Rabel's Recht des Warenkaufs (1936), ${ }^{24}$ the United Nations Sales Law Convention on the International Sale of Goods (1980), and the Lando Commission's Principles of European Contract Law (1995). ${ }^{25}$ Although the methodology used by these harmonization projects is not beyond criticism, it certainly is well-established being based on case studies, using functional comparative methodology, ${ }^{26}$ and frequently undertaken with a presumption or at least an expectation that similar cases will receive similar treatment regardless of the history, sources, structure, dogma and theory which underpins the legal systems involved. ${ }^{27}$

While many comparative lawyers use this methodology by default, it was unsuitable for the Acquis Group's work. Its task is not to unearth commonality hidden behind diverging rules in different legal systems, but to formulate commonality within EC law, arising from a few dozen directives and ECJ decisions,

22 On the use of the DCFR, see also Schulte-Nölke/Zoll, Structure and Values of the Acquis Principles: New features and their possible use for political purposes, in: Acquis Group (ed.), Acquis Principles, Contract II (supra, note 4), xxiii-xxxv.

${ }_{23}$ European Research Group on Existing EC Private Law (Acquis Group), Draft for a First Chapter (Subject-Matter, Application and Scope) of an Optional European Contract Law, prepared by Gerhard Dannemann, 2011 Oxford U Comparative L Forum 2 at ouclf. iuscomp.org.

${ }^{24}$ Rabel, Das Recht des Warenkaufs, Vol. I (1936), Vol. II (1954).

25 The Principles of European Contract Law Part I, Performance, Non-Performance and Remedies, The Commission on European Contract Law, Lando/Beale (eds.). Part I appeared in 1995, a full edition (Parts I and II) in 1999.

${ }^{26}$ For a critical review, see Michaels, The Functional Method of Comparative Law, in: Reimann/Zimmermann (eds.), The Oxford Handbook of Comparative Law (2006), pp. 339 et seq.

27 See Dannemann, Comparative Law: Study of Differences or Similarities?, in: Reimann/Zimmermann (eds.), The Oxford Handbook of Comparative Law (2006), pp. 383, 385 et seq. 
some regulations, and diverging incorporation practice in 27 member states. Case studies have some use, but while these can indeed reveal some common ground (as well as some differences), for example, between German and French rules on error and English rules on mistake and misrepresentation; they cannot perform the same function for what, for example, the Consumer Credit Directive, the Payment Services Directive and the Commercial Agents Directive may have in common. So the Acquis Group had to design its own methodological framework. In doing so, the Group faced the following three challenges in particular:

- How can one formulate EC contract law rules from a compilation of directives, regulations and case law which is not well known for its clarity and consistency?

- How can one formulate such rules if most of the EC law in the area of contracts is only concerned with consumer protection? (This is of course more of a problem for formulating contract law rules than it would be for intellectual property law rules.)

- And how can one get such a large group of scholars from so many different legal systems and traditions to find, let alone to agree on, these rules and principles?

The Acquis Group responded to this challenge by relying on the acquis communautaire for its methodology, namely, by using the well-established methods of interpretation of EC law. This is how the Group has formulated rules which transcend the existing piecemeal legislation approach but which at the same time can realistically claim to be based on the acquis.

The Acquis Group's methodology includes generalisation and extension of rules. It can be summarised as follows:

\section{Generalisation of Rules}

First, a search for common denominators can lead to a generalisation of rules. For example, numerous directives in the area of contract law contain provisions on pre-contractual information duties relating for example to the name and the identity of a business, or to information about price; these have been reformulated as general rules (Articles 2:205 and 2:206 ACQP). Art. 13-29 of the proposed Common European Sales Law contain similar rules on pre-contractual information duties.

Second, provisions on a particular topic which are dispersed over a variety of existing Directives can be interpreted and reformulated as an expression of a more general principle. For example, several directives establish the right of a consumer to withdraw from a contract during a cool-off period; the Acquis Group has generalised the requirements for such a right to withdraw from a con- 
tract negotiated away from business premises in Article 5:A-01 ACQP. A similar rule is now contained in Art. 40 paragraph (1) of the proposed Common European Sales Law. ${ }^{28}$

Third, in the reverse type of generalisation, other EC provisions on a particular topic which are also dispersed over a variety of existing directives can be understood as exceptions which, when taken together, reveal a more general principle. For example, several directives establish certain form requirements for particular situations; the Acquis Group has interpreted these as exceptions as a general principle of freedom of form in Article 1:304 ACQP. A similar rule is now contained in Art. 6 of the proposed Common European Sales Law.

The last two methods of generalisation may appear contradictory. It should be kept in mind, though, that none of the above methods of generalisation is automatic. In each instance, a purposive interpretation will be required in order to determine whether a pattern of regulation spread over various directives can be elevated to a general principle, is to be interpreted as exceptions to a general principle, or is not capable of being generalized.

\section{Extension of Rules}

In addition, the Acquis Group has extended EC rules beyond their wording. This is particularly relevant when a directive calls for the implementation of a particular rule, but leaves it to member states to regulate the consequences. While the Acquis Group has consistently taken note of incorporation practice in the member states, the question which it tried to answer in order to define the limits of EC contract law in this context was as follows: if the national legislator had done nothing or not enough to incorporate EC law, what consequences would the ECJ and domestic courts be likely to impose? For example, thirty years ago, if a job applicant had, in violation of EC law, been discriminated against by a prospective employer on the grounds of gender, all that person could claim under German law was reliance damages, calculated as the cost for copying and posting the application documents. In the landmark case of von Colson and Kamann, the ECJ held that this sanction was entirely insufficient. ${ }^{29}$ The ECJ stated that where the national legislator had failed to provide an adequate remedy, courts were empowered and obliged to override the insufficient provision and replace the measure of damages by one which was adequate in relation to the damage sustained - in order to give effet utile to the EC provision which had been violated. The Acquis Group has adopted this as its yardstick for

28 While Art. 2 and 40 paragraph (1) CESL continue to distinguish between "off-premises contracts" and "distance contracts", the requirements for and the effects of the exercise of a withdrawal right have otherwise been unified, as proposed by the ACQP.

${ }^{29}$ ECJ, case C-14/83, von Colson and Kamann v. Land Nordrhein-Westfalen, [1984] ECR 1891. 
the limits of formulating rules which transcend the existing piecemeal legislation approach but which, at the same time, can realistically claim to be based on the acquis communautaire.

\section{Policy Decisions}

The Acquis Group is aware that this generalisation and extension of rules involves policy questions. It believes that this holds true for any interpretation which must occur whenever a provision of EC law is applied to a particular case. Blank refusal to engage in any such decisions would essentially mean that EC law is incapable of being restated in a more simple, coherent and principled fashion, or of being developed by the courts. This is why the Acquis Group decided to engage in policy decisions to the degree outlined above, and at the same time to be open about the policy choices which it has thus taken by discussing them in the comments to the Acquis Principles (under heading B.3, "Explanation").

On the other hand, the Acquis Group has also frequently decided that the acquis provides an insufficient basis for taking such policy decisions by way of purposive interpretation. In these situations, a political decision through the appropriate organs is required in order to solve a particular problem within the acquis. Where this is the case, this is expressly mentioned in the comments to the Acquis Principles (under heading A.3, "Political Issues"). The Acquis Group has also sometimes indicated its disagreement with particular policies which are clearly evidenced in EC legislation, but has nevertheless based its restatement on the questionable policy - again on the grounds that any change would require a political decision.

\section{Group Structure and Drafting Process}

$$
\begin{gathered}
\text { Speaker \& } \\
\text { Co-ordinator }
\end{gathered}
$$

\begin{tabular}{|l|l|c|}
\hline $\begin{array}{l}\text { Redaction } \\
\text { Committee }\end{array}$ & - Joint Chair - & $\begin{array}{c}\text { Terminology } \\
\text { Group }\end{array}$ \\
\hline
\end{tabular}

\begin{tabular}{|c|c|c|c|c|}
\hline $\begin{array}{c}\text { Drafting } \\
\text { Team }\end{array}$ & $\begin{array}{c}\text { Drafting } \\
\text { Team }\end{array}$ & $\begin{array}{c}\text { Drafting } \\
\text { Team }\end{array}$ & $\begin{array}{c}\text { Drafting } \\
\text { Team }\end{array}$ & $\begin{array}{c}\text { Drafting } \\
\text { Team }\end{array}$ \\
\hline
\end{tabular}

\section{Plenary \\ Meeting}

Within the Acquis Group, different groups are responsible for different tasks in the process by which the Acquis Principles are adopted. 
The Plenary Meeting is a meeting of all members of the Acquis Group, presently convened twice a year. Its most important task is to discuss and adopt all the Acquis Principles, and it has the final say in this matter. Until the end of 2011, thirteen Plenary Meetings have been devoted to this task.

The Plenary Meeting, however, does not provide its own drafts. Group members combine to form Drafting Teams, which are set up to formulate rules for particular areas of contract law, such as rules on pre-contractual information duties, unfair contract terms, withdrawal from a contract, non-performance and remedies.

Once drafts have been formulated by the teams, they are passed on to the Redaction Committee, which formulates proposals for making the various drafts dovetail with each other, and generally prepares drafts for discussion and decision by the Plenary Meeting, in particular, by ensuring that different options are available for discussion where policy issues are involved.

The Terminology Group then edits this draft with a view towards harmonising the style and terminology, in order to improve the language and consistency of the drafts. Both the Redaction Committee and the Terminology Group will liaise with the drafting team to discuss these changes.

A substantial number of drafts have been through several cycles of deliberation by the Redaction Committee and/or the Terminology Group and the drafting team.

By the end of 2011, the Redaction Committee had met 19 times. This committee comprises some 8 members. The Terminology Group meets in cyberspace whenever required and consists of three members. The fact that the Redaction Committee and the Terminology Group are chaired by the same person, namely the present author, has facilitated the necessary co-ordination between the two bodies.

The following example demonstrates how two particular rules within the Acquis Principles have taken their present shape.

When the Drafting Team for our rules on withdrawal from a contract presented its first version, the first two provisions looked like this:

Art. 1 (Scope of application)

The rules of this subsection apply where a legal rule entitles one party to withdraw from the contract, or its declaration of intention to conclude a contract. They do not apply to withdrawal under Art. Xxx (sect. 4 sub-sect. 2).

Art. 2 (Exercise of a right of withdrawal)

Withdrawal requires a declaration from the entitled party to the other party, but no reasons.

The Redaction Committee added an option which would have made the exercise of the withdrawal right subject to a form requirement, as the acquis was not entirely consistent on this question. That option also made an exception for the 
case of withdrawal by return of the goods supplied under the contract. The Terminology Group also made some changes to this draft, such as replacing "legal rule" with "statutory right". Furthermore, the reference to "declaration of intention" was dropped because this notion neither formed part of the acquis, nor is easily understood across Europe. The draft which was then submitted to the Plenary Meeting looked like this:

Art. 1. Scope of application

The provisions in this subsection apply as mandatory rules where a party has a statutory right to withdraw from a contract.

Art. 2. Exercise of a right of withdrawal

(1) (OPT. 1): Withdrawal must be communicated from the entitled party to the other party in order to become effective. No reasons need to be given.

(OPT. 2): Withdrawal must be communicated in textual form on a durable medium by the entitled party to the other party in order to become effective. No reasons need to be given. Returning the subject matter of the contract has the same effect as a communication of withdrawal in textual form on a durable medium.

(2) The declaration of withdrawal becomes effective when it is dispatched.

The Plenary Meeting rejected the option which would have established a form requirement. It also rejected the "posting rule" of the draft, whereby withdrawal would have become effective on dispatch (rather than on receipt). The following is the wording of the provisions as they were adopted by the Plenary Meeting:

Art. 1. Scope of application

The provisions in this subsection apply as mandatory rules where a party has a statutory right to withdraw from a contract.

Art. 2. Exercise of a right of withdrawal

Withdrawal must be communicated from the entitled party to the other party in order to become effective. No reasons need to be given. Returning the subject matter of the contract is considered a tacit withdrawal.

Many provisions adopted by a Plenary Meeting have subsequently been reviewed for substantive and terminological consistency with the other Acquis Principles, and also in response to criticism. The present version of the above two provisions shows signs of these further revisions by both the Plenary Meeting and the Terminology Group. They now read as follows

Article 5:101: Mandatory nature

Where a party has a statutory right of withdrawal from a contract, the provisions in this section apply as mandatory rules.

Article 5:102: Exercise of a right of withdrawal 
A right of withdrawal is exercised by notice to the other party. No reasons need to be given. Returning the subject matter of the contract is considered a notice of withdrawal unless the circumstances indicate otherwise.

\section{Domestic Pre-Understanding and System Neutrality}

\section{Domestic Pre-Understanding}

Most lawyers have been trained in one legal system, and tend to see EC law from the perspective of that system. For this reason we approach EC contract law rules through what Gadamer has called Vorverständnis or pre-understanding. We see everything through spectacles tinted in a particular shade, and are normally not even aware of wearing those spectacles. ${ }^{30} \mathrm{It}$ was inevitable that the proposed rules, and often other contributions to the debate within the Acquis Group, would be affected by the particular pre-understanding of those who drafted or contributed in another ways.

Readers may have come across an article written by the Hungarian scholar Gyula Eörsi, entitled 'Unifying the Law. A Play in One Act, With a Song. ${ }^{31}$ In that play, the delegate from a country with centuries of case law tradition proposes a rule according to which "The dog shall bark". A delegate from a country proud of its civil code makes a counter-proposal that "The cat shall mewl". A conciliatory and generalising proposal is then put forward, according to which "An animal shall make a noise". This is warmly welcomed by functional comparativists (who always look at the output), but considered incorrect when looking at fish, and also dangerously broad. A compromise according to which "An animal shall make a non-human noise" is rejected because parrots will do just that. After many more helpful comments, the Drafting Party comes up with a lengthy provision. Its first two paragraphs read as follows:

Article 1

1. A noise [sound] shall be made [emitted] by any kind of a non-human [a human] being capable of [and fit for] making noise [emitting a sound], including dogs and cats [cats and dogs].

30 See also Frankenberg, Critical Comparisons: Re-thinking Comparative Law, 26 Harv. Int. LJ 411 et seq. (1985): Lawyers must recognize that they are 'participant observers' who understand other legal systems primarily from the perspective of their own, and are thus unable to attain a neutral position.

31 Eörsi, Unifying the Law. A Play on One Act, With a Song, 25 Am. J Comp. L, 658-662 (1977). 
2. A noise [sound] under paragraph 1 may be made [emitted] expressly or impliedly. It shall be of such a nature as can in the given circumstances reasonably be expected to be made [emitted] by the non-human [ahuman] beings of a different kind from the one which has actually made the noise [emitted the sound] as well as noises made [sounds emitted] by human beings, provided that such noises [sounds] sound non-human [ahuman] included, and subject to usages widely known to and regularly observed by [any particular branch of] [the branch involved of] the non-human [ahuman] community capable of [and fit for] making noises [emitting sounds]. Such imitation shall, subject to fraud, be deemed proper, if a reasonable non-human [ahuman] being could under the circumstances reasonably be deceived by the said imitation.

In Ë̈rsi's example, attempts to rise above domestic pre-understanding result in a highly complex, yet rubbery rule which is largely void of content.

Mewling cats have also visited the Acquis Group. One first draft looked like this:

Article xxx. (number to be decided). Form.

The law requires a written document to be authenticated by public authorities or professionals exercising public authority in respect to the following contracts:

Consumer credits contracts.

Contracts for the transfer of immovables.

Timeshare contracts.

Colleagues from Scandinavia and the UK, where no such public authorities exist, could not be convinced that this rule was part of existing EC law, and it had to be dropped.

This demonstrates how the Acquis Group has been coping with the issues posed by members' pre-understanding.

First, the Group has a built-in process of comparison by having everything discussed by a large group of scholars from different legal traditions. These sorts of things become noticed as a draft moves through the Redaction Committee, the Terminology Group and the Plenary Meeting. Nevertheless, this is a cumbersome and time-consuming exercise, and it is quite possible that examples of pre-understanding remain in the commentaries to the Acquis Principles, which cannot be processed, debated and adopted with the same level of scrutiny.

Second, a closer inspection will usually reveal that there is no basis in the acquis communautaire for such a national perspective.

However, even if the Group in its entirety has been able to rise above the domestic pre-conceptions of its members, some related problems remain: 


\section{System Neutrality}

The Acquis Principles, even more than unified rules such as those set out by the PECL, DCFR, and the future CFR, must be formulated in such a way that they can interact with different legal systems and legal traditions, preferably without taking sides.

Two examples were given above of provisions which were problematic in this respect: the provision which required notaries and the provision which presupposed the concept of “declarations of intention". Many other examples could be given of system neutrality problems. These problems can surface almost anywhere and affect the entire drafting process, including the scope of a project, the structure, where interfaces are to be set with surrounding areas of law, as well as the language and terminology used. It should also be mentioned that it is sometimes impossible to remain neutral.

\section{a) A “General Part"?}

The following is an example of a question in which system neutrality cannot be achieved. Which general rules transcend the component parts of contract law, or the law of obligations, or possibly all private law, and should be formulated at a general level? Within European contract law regimes, English and German law can be found at the extremes. German law has a notoriously oversized "General Part" in Book 1 of the Civil Code which contains, amongst other things, rules on the formation of contracts which have been generalised to the level of overarching private law rules. English law, on the other hand, appears to have little if any such general rules. Most other codifications, including the Dutch Burgerlijk Wetboek, occupy somewhat of a middle ground. The Acquis Principles have a very small "general part" which defines the scope, contains key rules on consumers and businesses, and on notice and form. The DCFR contains a larger, but still comparatively slender Book I with ten general provisions, and adds another ten in Book II Chapter 1, which, amongst other things, extend contract rules to what are called "juridical acts”.

\section{b) Language and Terminology}

Language and Terminology offer particularly rich examples of problems with domestic pre-understanding and system neutrality. ${ }^{32}$ The first such problem is that one language must normally be chosen for drafting - English in the case of the Acquis Principles.

Eörsi's article shows one possible danger, namely, that any drafting language will not be the native language of most of those who are involved in the drafting:

32 See Dannemann/Ferreri/Graziadei (supra, note 5); Dannemann/Ferreri/Graziadei, Language and Terminology, in: Twigg-Flesner (ed.), The Cambridge Companion to European Union Private Law (2010), pp. 70 et seq. 
The Delegate from Linguaria: Me asking floor Chairman... to propose language bettering... in spite of "non-human" we can say "ahuman". This better English language I believing. Thank you so well Chairman. ${ }^{33}$

However, in the experience of the Acquis Group, the real problems with language are caused by terms which look perfectly acceptable to native speakers.

Take for example the good old English word "shall”, an expression with a long pedigree in legislative drafting which, if nothing else, appears to add gravitas to every rule in which it is used. As, for example, in "The dog shall bark". In the recent Commission Proposal for a Directive on Consumer Rights, 34 "shall" has been used 136 times, and it conveys at least five different meanings. For example, this proposal states:

"The order form shall include the standard withdrawal form set out in Annex I(B)".

The use of simple present tense in the Dutch, German, Italian and Polish versions is not much better. The German version states:

“Das Bestellformular enthält das Standard-Widerrufsformular gemäß Anhang I Teil B“.

This could mean any of the following:

- An enforceable obligation: consumers have the right to receive the form

- An unenforceable obligation: consumers have no such right, but have other remedies if they do not receive the form

- The rule just provides information about the standard procedure and creates no obligation, duty or consequence, provided the required information is given

Using "shall” or the simple present tense are examples of unnecessarily obscure language. This is a terminology trap which can be easily avoided. Neither the Acquis Principles, nor the DCFR, nor the Feasibility Study use "shall”.

Other terminology traps have been caused by EC legislation and its highly inconsistent use of terminology. One example is provided by the many terms which have been used to describe the first party in a business to consumer transaction. The Acquis Principles, the DCFR and the Feasibility Study call this party, unsurprisingly, a business. The EC legislation oscillates between this word and the terms "professional”, "supplier", "professional supplier”, and "trader". 35

33 Eörsi (note 30), at 660.

$34 \mathrm{COM}(2008) 614$ final. See European Research Group on Existing EC Private Law (Acquis Group), Position Paper on the Proposal for a Directive on Consumer Rights, (2009) Oxford U Comparative L Forum 3 at ouclf.iuscomp.org.

35 As used in both the Proposal for a Directive on Consumer Rights, COM(2008) 614 final and in the Proposal for a Regulation on a Common European Sales Law, COM (2011) 635 final. The term "trader" is as misleading as its German corollary, "Gewerbetreibender", as both suggest that it is limited to those businesses which are associated with a particular trade. 
The use of English as drafting language presents another problem where system neutrality is impossible to obtain and where domestic pre-understanding will play tricks on the reader. English legal language includes a number of terms which have a certain common law meaning. They invite the reader to apply an English pre-understanding of EC law. The Acquis Group has for instance gone to great lengths to avoid using the word "consideration" for fear that this will be understood in the sense of the "doctrine of consideration", which would lead back to "The dog shall bark".

However, there are limits to the number of contract law terms which the English language can provide. Sometimes new expressions - so-called neologisms - have to be coined. The Acquis Group has largely avoided neologisms, as they carry their own problems - in particular not being comprehensible. Some successful neologisms can be found in EC legislation, such as "Undertaking for Collective Investment in Transferable Securities". ${ }^{36}$

Another way of coping with linguistic pre-understanding is semantic change. An example is the way in which ACQP, DCFR and PECL use "creditor" and "debtor" as parties who have a right and who are under an obligation. In English legal terminology, the two terms are used only for monetary claims. Semantic change is painless for those who are not native speakers, but more difficult for those who are. One can indeed gain the impression that PECL, DCFR and ACQP, although generally written in excellent English, may be more easily understood by people who are not native English speakers, because they are not impeded by domestic pre-understanding of English legal terminology.

\section{Model Function?}

Can the Acquis Principles serve as a model for similar projects and in particular for one on "Common Principles of European IP law"?

One could point out that the interests of the Acquis Group, as evidenced in its full name, are not limited to contract law. As mentioned above, the Group is presently embarking on a restatement of tort law. The methodological issues which have been outlined above are not particularly attached to contract law or even to the law of obligations.

However, it should be borne in mind that the Acquis Group methodology has been designed for a restatement, that is, a shorter, clearer and more consistent formulation of existing law, which leaves many gaps in areas for which there is no acquis. In terms of changing existing black letter rules, the Acquis

36 Directive 85/611/EEC in the field of undertakings for collective investment in transferable securities (UCITS). 
Group does not aim to venture beyond removing a few unexplainable and accidental inconsistencies.

The more ambitious alternative is a law unification project, usually culminating in a model code which aims to formulate a complete set of more or less new rules, in line with the PECL and those DCFR rules which were formulated by the Study Group. Such projects require a different methodology, as for instance the functional comparative approach chosen for the PECL and by the Study Group.

On the other hand, some methodological issues are identical, in particular those relating to the process of formulating rules, to domestic pre-understanding, to a large degree also to system neutrality, and to language and terminology. The Acquis Group's experience with its working method may therefore have some relevance to anybody who wishes to restate, or even harmonize, European rules on intellectual property law. 

II. Substantive Intellectual Property Law 



\title{
Grounds of Protection: How Far Does the Incentive Paradigm Carry?
}

\author{
Alberto Musso
}

\author{
I. The incentive paradigm: \\ from various patterns of economic or moral incentives \\ for creative innovators to the main reward \\ for industry investment
}

As far back as four years ago, in the foreword of its last relevant paper on intellectual property issues ${ }^{1}$, the EC Commission firmly affirmed that a high level of copyright protection is crucial for intellectual creation: "copyright ensures the maintenance and development of creativity in the interests of authors, producers, consumers and the public at large. A rigorous and effective system for the protection of copyright and related rights is necessary to provide authors and producers with a reward for their creative efforts and to encourage producers and publishers to invest in creative works (...). Copyright is also a policy in line with the imperative to foster progress and innovation". The restatement of the incentive paradigm could not have been more explicit than these words, which also clearly stress that the reward is no longer granted for intellectual creation as such (i.e. for authors), but rather it is mainly granted for the investment in production (i.e for broadcasters, publishers, etc. $)^{2}$. This trend is totally reasonable

${ }^{1}$ EC Commission, Green Paper on Copyright in the Knowledge Economy, COM(2008) 466/3. See a "Comment" by the Max Planck Institute for Intellectual Property, Competition and Tax Law, Munich, 37 IIC 551 et seq. (2006), suggesting a more balanced "two-tiers" approach instead of "one-way" protectionist paradigms based on rent-seeking models only.

${ }^{2}$ For general criticism from an economic perspective, see Towse (ed.), Creativity, Incentive and Reward. An Economic Analysis of Copyright and Culture in the Information Age (2001). It is still questionable, however, whether copyright should operate as an incentive since its earlier statements: Art. 2(4) of the Berne Convention for the Protection of Literary and Artistic Works allows the Countries of the Union to determine the extent of protection to be granted to official texts of a legislative, administrative and legal nature, and to official translations of such texts: is this perhaps a way to stimulate and enhance the creation of... statutory law? See, e.g., the Vatican Decree, 31 May 2005 (available at http://www.vatican.va/ roman_curia/secretariat_state/2005/documents/rc_seg-st_20050531_decreto-lev_en.html), issued in order to protect, in particular, the Pope's encyclicals and (re)affirming the protection of every moral right and of all exclusive financial rights - without any exception - over all 
to a certain extent - considering the high costs incurred in advance by the cultural industries which are not often recovered because of the very nature of the goods in question ${ }^{3}$ : the favouring of investors over authors, however, is liable to unbalance the whole system of intellectual property far away from the balance struck in its early beginning to its position at the time of the Statute of Anne, under which copyright was "vested in authors" for a limited period of time and not in publishers ${ }^{4}$. Indeed, even in the countries which are more oriented towards a "personality right" approach - like France and especially Germany, where authors still cannot assign their economic rights other than through Nutzungrechte ${ }^{5}$ - it is also questionable that authors' rights have become "neighbouring" to producer's rights rather than vice-versa: even in these countries, as a matter of fact, author's rights are presently quite comparable to designers' or inventors' rights $^{6}$, as they concern more industrial patterns of creation which are more suited to the assignment of exclusive rights to the investing firm. Since the origin of capitalism in the sixteenth and seventeenth century, in the case of subject matter vested with copyright or patent rights, the incentive paradigm has been assumed to be the best way to foster innovative creation, by granting economic rewards to the authors of works or inventions. The sovereign practice of granting privileges ${ }^{7}$ might be seen as an earlier model of this paradigm, that begun when creators needed to earn money through their own intellectual efforts not only because the noblemen were no longer able to provide patronage to the arts and sciences (as Maecenas did in the past) ${ }^{8}$, but also because works or inventions could be reproduced with increasing ease in turn all over the mar-

the deeds and documents through which the Supreme Pontiff exercises his own Magisterium. In these cases - as well as in the time of the Stationers' Company - copyright is the main tool employed to control the "correct" dissemination of works, through the application of economic rights, which arise after creation is completed (such creation also having arisen independently of those rights).

3 On recovery of fixed and sunk costs, see Caves, Creative industries. Contracts between art and commerce (2000), pp. 223 et seq.

${ }^{4}$ M. Rose, Authors and Owners: the Invention of Copyright (1993), pp. 45 et seq.

5 Dietz, entry "Germany", in Geller (ed.), International Copyright Law and Practice (2008), $\$ 4.2$, pp. 54 et seq.

${ }^{6}$ According to the seminal distinction between industrial property and droit d'auteur, under the Paris and the Berne Conventions.

7 On privileges in Venice for printed works and inventions, see - inter alias - Witcombe, Copyright in the Renaissance. Prints and the Privilegio in Sixteenth-Century: Venice and Rome (2004).

${ }^{8}$ See e.g. the case of F. J. Haydn, tolerating and also fostering the free dissemination of his musical works in order to gain fame and fortune, while he was employee as vice-chapelmaster, then, as "free lancer" and among the first composers to organize concerts for hire, bringing legal suits against unauthorized reproductions or executions: for more information and analysis, Tschmuck, Creativity Without a Copyright: Music Production in Vienna in the Late Eighteenth Century, in Towse (ed.), Copyright in the Cultural Industries (2002), pp. 213 et seq. 
ket $^{9}$. In the absence of further analysis - as occurred in England when the Statute of Monopolies and the Statute of Anne were enacted ${ }^{10}$ - the exclusive privileges granted to works or inventions, on the Continent, became fundamental "natural" rights, arisen as an equalitarian reaction, more instinctive than pondered $^{11}$, to the discretionary powers of Absolutism which had reigned since the French Revolution and also as a consequence to Kant's defense against the Prussian censorship ${ }^{12}$. Lockean theories on the appropriation of the results of labour as a fair reward for any worker, as well as on the holy nature of property rights in intellectual creation ${ }^{13}$, were further strengthen in the Romantic age, when Novalis made artists and priests equal ${ }^{14}$. This mixture of both personal and financial rights - aiming to acknowledge the moral and economic incentives for creative innovation respectively - perhaps might also provide a historical explanation for the theoretical influence of the "reward theory" on intellectual property under the "doctrine of fundamental rights" 15 . Before accepting this paradigm, however, it is first necessary not only to resolve the question of how much or in which way (quomodo or quantum) an incentive might be adequate, but also to get more to the heart of the matter by questioning whether (an) economic reward is the most suitable or the only tool for fostering creative innovation and for fairly protecting authors' or inventors' efforts: both of these aspects must be

${ }_{9}$ Benjamin, The Work of Art in The Age of Mechanical Reproduction (2009, reprint), pp. 2 et seq.

${ }^{10}$ For discussion of the protection of patents and copyright, especially as regards the (limited) term on duration of protection in the Statute of Anne and the Statute of Monopolies, see M. Rose, Authors and Owners (supra, note 4), pp. 42 et seq.

11 As correctly remarked by MacMillan, Copyright and Corporate Power, in Towse (ed.), Copyright (supra, note 8), 99 et seq., "this notion has now reached the status of a mantra and, befitting such a status, is chanted more often than analysed".

12 Maybe the different approach of the "two copyrights" on the European Continent and in the Anglo-American system arises from these historical reasons. In England, the greater freedom of speech enjoyed since the abolition of the Star Chamber in 1641 and the enactment of the Bill of Rights in 1689 made case law and statutory law more concerned with the economic aspects of the subject-matter; on the contrary, the more "personal" approaches of the author's rights systems, in Germany and France, were probably construed as relating to an an aspect of the author's personality in order to grant him/her, above all, the freedom of expression lacking in France as well as in Prussia or in other continental kingdoms under absolutism.

${ }_{13}$ Compare the Lockean with the German legal philosophers' (such as Hegel's) doctrines, in Drabos, A Philosophy of Intellectual Property (1996), respectively at pp. 42 et seq. and 75 et seq.

${ }^{14}$ From this extreme and exagerated Romantic perspective, copyright had to be perpetual. Poets like Woodsworth, for example, strongly supported an unlimited duration during the drafting of the British Copyright Act enacted in 1842: M. Rose, Authors and Owners (supra, note 4 ), p. 112, in the text and at note 12 . Of course, no incentive to create was present in this theory, but only a hyper-individualistic (and utopic) transposition of an exaggerated "eternal" literary life into legal property rights on the authors' works of intellectual creation.

15 See infra, text and note 113. 
taken into account because the legal system is not only intended to stimulate the optimal level of efficiency, but also to cuique suum tribuere ${ }^{16}$ according to everyman's fundamental rights. From this point of view, in the literary or artistic domain, it has been stressed that economic reward has not always been the main incentive for creation: in the past as today - from J. S. Bach to creators of open-source programs ${ }^{17}$ - creating works is often a pleasure or an intellectual yearning to express one's own capabilities, experiences, emotions, etc. ${ }^{18}$, not unlike the pleasure (or perhaps the pride) of raising children and presenting them to society ${ }^{19}$. In such cases a (further) incentive to create might be found in the (further) notoriety consequent on the dissemination of the work $^{20}$, which may be considered to be one of the main (alternative) incentives to economic prizes: even if compelled to earn money in the absence of patronage, many writers or artists have continued to create works for the pleasure of communicating their own knowledge or feelings rather than for economic reward, which might in any case remain necessary for their sustenance ${ }^{21}$. Very similar - albeit not often investigated - moral incentives might also be said to exist in the technical domain, notwithstanding the creation of a "mythology of innovation" with regards to certain "patent heroes", such as J. Watt, to take one example 22 . In fact, the development of Watt's pumping engine and its related technique was under-

16 I.e. "to give to each one that which belongs to him" (Justinian, Institutes, I, 1.1), translation by S. P. Scott.

17 On moral incentives and open science - especially in the academic environment - see Chesbrough, Vanhaverbeke E West, Open Innovation. Researching a New Paradigm (2006); Scotchmer, Innovation and Incentives (2004), pp. 252 et seq.

18 Since the theories by Huizinga, Homo ludens (2002, first printed in England 1949), pp. 105 et seq.

19 Martialis, Epigrams, I.52, first transferred the legal term for "kidnapping” in Roman law to plagiarism of the works of intellectual creation (of course, at that time, only in respect of the moral right of paternity on these works).

20 Thus fame might be a further, but not a necessary ingredient of the personal incentives for creation, as protection for anony mous or unpublished works - granted by many copyright laws - demonstrates. E.g., before his death - as it is quoted in the Publisher's introduction to Kafka, The Castle (1998), pp. iv et seq. - the famous Jewish author wrote to his executor, M. Brod: "Everything I leave behind me (...) in the way of diaries, manuscripts, letters (my own and others'), sketches, and so on, [is] to be burned unread". Brod however disregarded Kafka's will and edited most of Kafka's unfinished works publishing them in honour of his memory.

${ }^{21}$ See e.g. Benhamou, L'économie de la culture (2008), pp. 11 et seq., distinguishing between more or less "economy-oriented" authors/producers and creators more driven/encouraged/incentivised by moral incentives, such as prestige, credit or personal satisfaction (ars gratia artis). For a similar distinction in the area of technological innovation, see Grandstrand, The Economics and Management of Intellectual Property. Towards Intellectual Capitalism (2000), pp. 85 et seq.; Cullis, Patents, Inventions and the Dynamics of Innovation. A Multidisciplinary Study (2007), pp. 19 et seq.

22 The mythology of single "patent heroes" has grown around some insulated macro-inventions, since the Industrial Revolution in Great Britain: see e.g. Cardwell, The History of Technology (1994), pp. 496 et seq. 
taken from 1800 to 1904 by Cornish managers in the mining districts, without patents, but instead through the passing on of common knowledge which improved over time and which was disseminated in the "Lean's Engine Reporter" from $1811^{23}$. This example demonstrates not only the existence of an alternate paradigm - instead of patents or similar incentives - which founded upon the reputation that the engineers could gain by publishing their innovations and thus improving their career prospects, but also demonstrates that an alternative incentive to disseminate knowledge, rather than maintaining it secret, exists ${ }^{24}$ : an incentive which is often considered to be an exclusive advantage of the patent system, especially in industrial circles, where diffuse "hidden knowledge" is often not patented and not secret at the same time ${ }^{25}$. This alternate paradigm currently exists for discoveries or other innovative information with no industrial application under Articles 52 and 57 of the European Patent Convention: however, these provisions have never been criticised for hampering the incentives to develop discoveries, scientific theories, mathematical methods, as well as schemes, rules and methods for performing mental acts, playing games or doing business (e.g. for door-to-door sales or for e-commerce) ${ }^{26}$, even though they grant the authors, at most, a moral right of paternity ${ }^{27}$. Copyright also does not protect any idea, method, concept, process or style as such ${ }^{28}$, even if it is the heart of a new work of authorship, for example in advertising (see Article 9.2 TRIPs): although only expressly provided for in Article 1.2 of EEC Directive No 91/250, 14 May 1991, on the legal protection of computer programs, this provision must also be deemed to be a main principle of copyright law in Europe, which also has not hindered the increasing worldwide production of new works. In these cases too, the protection of ideas as such might result from fame or credit: it is quite reasonable to assume that every imitation of an idea grants

${ }^{23}$ Nuvolari, Collective Invention during the British Industrial Revolution: The Case of the Cornish Pumping Engine, (2004) 28 Cambridge Journ. of Econ. 355 et seq.

${ }^{24}$ Nuvolari, Collective Invention (supra, note 23), p. 357;

${ }^{25}$ For further references see Wang, Research of Technological Innovation System for Industry Clusters, in International Seminar on Future Information Technology and Management Engineering, November 20, 2008, Leicestershire (UK), at http://ieeexplore.ieee.org/ Xplore/login.jsp?url=http\%3A\%2F\%2Fieeexplore.ieee.org\%2Fiel5\%2F4746419\%2F47464 20\%2F04746514.pdf\%3Farnumber\%3D4746514\&authDecision=-203.

${ }^{26}$ Rivette E Kline, Rembrandts in the Attic: Unlocking the Hidden Value of Patents (2000), pp. 16 et seq.

27 Since basic research and mental steps, thoughts or ideas must remain free: Ghidini, Innovation, Competition And Consumer Welfare in Intellectual Property Law (2010), pp. 43 et seq.

${ }^{28}$ See Füller, in Stoll, Busche \& Arend (eds.), WTO - Trade-Related Aspects of Intellectual Property Rights (2009), pp. 250 et seq.: "any Member providing copyright protection for ideas, procedures, methods of operation or mathematical concepts is violating the TRIPs Agreement (...). Hence, Members that have rather broadly drafted their national copyright law must provide for its interpretation and application in conformity with Art. 9.2 TRIPs". 
the original author even more fame and credit - provided that his/her paternity is already established among the public - while subsequent creators, in their turn, are left free to improve upon the same idea through different and innovative means of expression ${ }^{29}$.

\section{From "cultural" or "technological" intellectual property to merely "financial" intellectual property?}

This alternate model mainly based on the moral incentives, however, is not sufficient to completely replace the incentive paradigm grounded on the economic rewards, either in theory or in practice: the high costs required for the manufacture of innovative products or services and their distribution on a commercial scale - even when their production has been directly motivated only by personal or moral incentives ${ }^{30}$ - have made necessary to create legal tools for recovering at least the costs of investment, if not also for ensuring some profit. In reality, the inventions and the other intellectual creations are being increasingly created or managed by entrepreneurial firms rather than by individual inventors and authors, who could better balance moral interests with economic returns. In the past, inventions and intellectual creations were also managed by firms, but the entrepreneurial activity was often undertaken by the same individual creators or innovators and continued by their flesh-and-blood descendants: nowadays - on the contrary - even the most "sacred and personal property" is increasingly being controlled by hedge funds or other speculative legal entities $^{31}$ : also in terms of market structure, the increasing globalization of the

29 Landes E Posner, The Economic Structure of Intellectual Property Law (2003), pp. 91 et seq., however trying to reduce this basic principle - developed on the grounds of both equitable and practical justice - to a mere economic formula for the purpose of market efficiency.

${ }^{30}$ For this reason, aesthetic creations, the presentation of information and programs for computers - originally excluded from patentability under Art. 52 EPC - have been otherwise protected by copyright, registered design and model or topography rights, etc., unlike many other innovations mentioned in the same provision, which are still not protected at all by property rights or other rights.

${ }^{31}$ See e.g. Chandler E Henning, Access to Finance For the Cultural and Creative Industries in the South East of England, Report Summary, December 2009, commissioned by South East of England Development Agency (SEEDA) on behalf of the Creative Economy Partnership, p.6, available at http://www.seeda.co.uk/_publications/Final_CEP_AF_Re port_Summary_26_Feb.pdf: "traditionally much content development and production funding has been provided by the trade itself, by publishers and distributors with relatively little provided by private equity houses, business angels, venture capitalists or other financial institutions. This has meant that creative companies have not needed to develop the private investor presentation skills that the financial markets demand. This is changing however as new business models driven by digital and online developments disrupt this conventional model" $(\$ 1 . v)$. 
firms, the process of mergers or acquisitions ${ }^{32}$ and the transformation of patents and copyright into mere financial instruments - like stocks, bonds or other securities $^{33}$ - has turned intellectual property into a mainly investment-based activity. As a consequence, on the legal side, the moral aspects or personal rights have been totally neglected in the process of EU harmonization ${ }^{34}$, which has gradually striken the original balance between private reward and social welfare by almost exclusively providing economic incentives for incumbent investors - as reported in the Green Paper mentioned ${ }^{35}$ - and by elevating this paradigm to quite a dogmatic axiom. This progressive trend is observable in all other domains of EU Law on intellectual property: see e.g. the specific suigeneris regime established for the legal protection of topographies in semiconductor products by the EEC Directive No 87/54, 16 December 1986, since "semiconductor products are playing an increasingly important role in a broad range of industries and semiconductor technology can accordingly be considered as being of fundamental importance for the Community's industrial development" (Recital No 1); or the more recent protection granted to biotech processes in the environmental domain under the EC Directive No 98/44, 6 July 1998, on biotechnological inventions, "whereas the patent system should be used to encourage research into, and the application of, such processes” (Recital No 10) ${ }^{36}$.

32 Needless to say, however, the Court of Justice seems to appreciate concentrations as well as a high protection for IP rights: see ECJ, case C-413/06, Bertelsmann and Sony v. IMPALA, [2008] EDR I-4951, reversing for affirmed errors in procedural law both the General Advocate's conclusions and the Court of First Instance's judgment of 13 July 2006, T-464/04, which annulled the EC Commission's clearance decision on the Sony/BMG merger for collective dominance (O.J., 9 March 2005, L 62, 30), after a complaint by the Independent Producers and Labels Association. For an analysis of phonographic markets, characterized by high barriers to entry and oligopolistic merges, see Regner, Innovation of Music, in Gordon \& Wyatt, (eds.), The Economics of Copyright. Developments in Research and Analysis (2003), pp. 106 et seq.; as for innovations after mergers or acquisitions, Lindgaard E Ringeling, in Lidgard \& Atik (eds.), The Intersection of IPR and Competition Law (2008), pp. 221 et seq.

33 See e.g. Recital No 2 of EC Directive No 2001/84 "the resale right is a right of a productive character which enables the author/artist to receive consideration for successive transfers of the work".

${ }^{34}$ See e.g. Recital No 19 of EEC Directive No 93/98: "the moral rights of right holders should be exercised according to the legislation of the Member States and the provisions of the Berne Convention for the Protection of Literary and Artistic Works, of the WIPO Copyright Treaty and of the WIPO Performances and Phonograms Treaty. Such moral rights remain outside the scope of this Directive". The same wording is in the Recital No 19 of both EEC Directive No 92/100 and EC Directive No 29/2001.

35 Supra, text and note 1.

36 As for orphan diseases, however, see infra, text and note 43. 


\section{Present EU grounds for IP protection}

\section{The equation: "incentive = exclusive rights of economic exploitation"...}

If the establishment of legal protection for investment thus shifts the balance towards economic rather than moral or personal incentives, this reward, on its turn, is still too much dogmatically and automatically identified in an "intellectual property" right, i.e. in the exclusive right to prevent all third parties from using the intangible assets which are objects of the protection - absent the proprietor's consent - as it is typically established by patent law or copyright since the privilege system ${ }^{37}$. On the contrary, many economists studying innovation and culture, as well as some lawyers, not considering intellectual property to be the sole model to be taken into account, have analysed different models of economic incentives ${ }^{38}$ including: prizes offered in advance of creation to any firm (or only to specialized ones) by public or by private sponsors - conditioned on delivery of specified creations - and payments by procurement agreements after the creation has been made, e.g. through auctions or research agreements. These mechanisms, similar to ancient patronage, however, have their pros and cons, thus might best stand side by side to intellectual property instead of being complete substitutes for patents or copyright. Private or public sponsorship may be particularly useful in fostering creative innovation when the market as such does not provide sufficient incentives - e.g. for developing unpatentable discoveries or other basic research or for financing movies of cultural value that might not meet commercial goals ${ }^{39}$ - but discretional "public choices" on what is worth funding and what is not, may become difficult especially if public money is involved and the burden of public payment is shared among all taxpayers ${ }^{40}$.

37 See also the same property right in trademarks under Art. 5.1 of the EEC Directive No 89/104, 21 December 1988, issued to approximate the laws of the Member States relating to trade marks.

${ }^{38}$ Gallini \& Scotchmer, Intellectual Property: When Is It the Best Incentive System?, in Jaffe, Lerner and Stern (eds.) Innovation Policy and the Economy, Vol. 2, pp. 51 et seq.

39 On the "cultural exception", in order to keep the European audiovisual works out of TRIPs and the OMC under the EEC Directive No 89/552 as amended by Art. 13 of the "Audiovisual Media Services” Directive No 2007/65/EC, see Mallet-Poujol, Marchandisation et audiovisuel, in Vivant (ed.) Propriété intellectuelle et mondialisation. La propriété intellectuelle est-elle une marchandise? (2004), pp. 85 et seq.

40 Especially when public money is involved in academic or other entities' research projects, however, patents or other protectable innovations should be disseminated for free (otherwise taxpayers would pay e.g. a patented drug twice, financing it in advance then paying for the protected product when it is put on the market). On the contrary, academic research financed by public money gives rise to ordinarily patented results both in European Countries and the United States (Bayh-Dole Act). See Wright, The Economics of Invention Incentives: Patents, Prizes, and Research Contracts, in 37 Am. Econ. Rev. pp. 691 et seq. (1983); following Scotchmer, Innovation and Incentives, (supra, note 17), p. 243, in this case, "two possibilities have been suggested for how to reconcile the apparent contradiction between disseminating 
The advantage of property rights in creative innovation is that they contain a self-paying mechanism, so that the cost effectively falls only on users: in this way, moreover, useful innovations and worthy intellectual creations might be rewarded in themselves ${ }^{41}$, without any charge to taxpayers and without the use of the discretional powers of private and public authorities. To implement this mechanism, nonetheless, an exclusive right in respect of the intangible assets is commonly considered to flow from the doctrine of property, as noted above: to be rewarded, the proprietors must be the sole controllers of "their" intangible assets, because competitors may easily copy the information necessary to recreate the creative innovation without expending the initial investment costs - unlike material copies of commodities - so giving rise to the axiomatic equation "creative innovation $=$ investment $=$ incentive/reward $=$ copyright $/$ patent $=$ exclusive right", in order to prevent free riders from despoiling the proprietors' preserve $^{42}$. All the terms of this equation are clearly deductable from EU Law on intellectual property: see, e.g., Recital No 2 of the EEC Directive No 87/54 ("the development of such topographies requires the investment of considerable resources, human, technical and financial, while topographies of such products can be copied at a fraction of the cost needed to develop them independently"); Recital No 2 of the EEC Directive No 91/250, 14 May 1991, on the legal protection of computer programs (with the same wording as for creation and investment in software); Recital No 7 of the EC Directive 96/9, 11 March 1996, on the legal protection of data-bases (with the same words as for database design); Recital No 3 of the EC Directive No 98/44 (“effective and harmonised protection

knowledge and patenting it. One is that patenting gives the university an incentive to find licensees, and the other is that patenting gives users an incentive to make collateral investments to commercialize inventions. Neither rationale is entirely convincing".

${ }^{41}$ See Grandstrand, The Economics and Management (supra, note 21), p. 31, remarking that, since the privilege system, "the privilege holder was remunerated by the ruler, but in such a way that the ruler, that is, the privilege granter, did not to pay for it fully and directly", because the payment was actually shifted to the effective users of the invention or the work this became "an attractive mode of financing for the privilege granter". This means that IP rights operate as free incentives for the State, granted in return for contributions to common welfare, but, unlike other State aids, directly paid by the users and, therefore, without cost to the Treasury: this mechanism can explain the increasing over-extension of IP rights, that may therefore be easily acknowledged - also in Europe - as a very attractive "political" tool in order to satisfy all industrial claims for more and more protective subsidies with no payment by public funds (but shifted to... private pockets): infra, text and note 46 . On patents and other IP rights as public subsidies, in particular, see Boldrin $\mathcal{E}$ Levine, Against Intellectual Monopolies (2008), 260 et seq.

42 According to the seminal studies by Arrow, Economic Welfare and the Allocation of Resources for Invention, in Nelson (ed.), The Rate and Direction of Inventive Activity: Economic and Social Factors, National Bureau of Economic Research (1962), pp. 609 et seq.; however, as remarked by Gallini \& Scotchmer, Intellectual Property: When Is It the Best Incentive [supra, note 38], p. 53, "Arrow explained why some incentive scheme is needed, but not which scheme". 
throughout the Member States is essential in order to maintain and encourage investment in the field of biotechnology"). The restatement of the final term of the equation is often unconditional, especially when sui generis protection or even alternate mechanisms for the stimulation of investment are available: see e.g. Recital No 8 of the EC Directive No 98/44 (the "legal protection of biotechnological inventions does not necessitate the creation of a separate body of law in place of the rules of national patent law", which thus "remain the essential basis for the legal protection of biotechnological inventions given that they must be adapted or added to in certain specific respects in order to take adequate account of technological developments involving biological material which also fulfil the requirements for patentability"); Recital No 5 of the EC Directive No 96/9 ("copyright remains an appropriate form of exclusive right for authors who have created databases"). It does not seem possible to identify other incentives to invest but through property rights ${ }^{43}$ : all further paradigms appear to have been totally dismissed in the EU grounds for protection, only being mentioned - in a vague and aspirational manner only - when the failure of a market-based reward model can not be hidden, as in all cases where scientific or cultural development is not profitable enough. See e.g. Recital No 18 of EC Directive No 98/44: "since the patent system provides insufficient incentive for encouraging research into and production of biotechnological medicines which are needed to combat rare or 'orphan' diseases, the Community and the Member States have a duty to respond adequately to this problem", but a clear response to such a question has neither been given from the Directive nor from the whole EU IP Law system as of yet. In fact, Recital No 8 of the EC Regulation No 141/2000, 16 December 1999, on orphan medicinal products seems to contradict the above mentioned statement, reaffirming that "experience in the United States of America and Japan shows that the strongest incentive for industry to invest in the development and marketing of orphan medicinal products is where there is a prospect of obtaining market exclusivity for a certain number of years during which part of the investment might be recovered", while "data protection under Article 4(8)(a)(iii) of EEC Directive 65/65 of 26 January 1965 on the approximation of provisions laid down by law, regulation or administrative action relating to medicinal products is not a sufficient incentive for that purpose"; however, market exclusivity should "be limited to the therapeutic indication for which orphan medicinal product designation has been obtained, without prejudice to

43 As strongly supported e.g. by Lehmann, The Theory of Property Rights and the Industrial and Intellectual Property, in 20 IIC 1 et seq. (1989); as for patents, see in particular Kieff, On the economics of patent law and policy, in Takenaka, Patent Law And Theory. A Handbook of Contemporary Research (2009), pp. 3 et seq., relying on the property rights as the best incentive to produce and also to license through the huge powers of control granted by the enforcement of property, such as the direct injunctions, instead of the mere contractual or other liability-based remedies. 
existing intellectual property rights" and only "in the interest of patients, the market exclusivity granted to an orphan medicinal product should not prevent the marketing of a similar medicinal product which could be of significant benefit to those affected by the condition", while - once again through the "incentive plus exclusivity" leit motiv - the "sponsors of orphan medicinal products designated under this Regulation should be entitled to the full benefit of any incentives granted by the Community or by the Member States to support the research and development of medicinal products for the diagnosis, prevention or treatment of such conditions, including rare diseases" (Recital No 9), but therefore restricting possible $\mathrm{R} \& \mathrm{D}$ by third parties.

\section{2. ... and its axiomatic corollary: "the highest level of exclusive protection = the highest incentive for creative innovation"}

Notwithstanding the great debate on this subject though the centuries, the proprietary model is still considered as the best way to foster investment by EU IP Law: it would not only be more rightful, according to Lockean theories on the appropriation of the results of one own's labour, but it would also be a more efficient way to achieve higher levels in creative innovation and dissemination. In particular, since J. A. Schumpeter's well-known perspective - still implemented today by huge arrays of neo-Schumpeterians ${ }^{44}$ - the concentration of property rights in the hands of a few big businesses, would allow these firms to obtain financial incentives and intellectual resources for achieving greater innovation with long steps rather than a collection of many smaller firms competing amongst themselves. From this perspective, today's economists have sometimes expressed their preference for a "big" or "long” patent extension (in terms of scope or duration) in order to encourage original right holders to engage in further investment in order to develop all of the possible following steps in the destructive/creative processes of intellectual innovation ${ }^{45}$ on the assumption that

${ }^{44}$ On this subject, compare Winter, Toward a neo-Schumpeterian Theory of the Firm, in Industrial and Corporate Change (2006), pp. 125 et seq., with Liebowitz, When Is Market Destruction Creative?, 25 May 2009, available at http://www.iposgoode.ca/2009/05/when-ismarket-destruction-creative/. This point of view is complementary to the criticisable "prospect" (or "free hunting") theory - originally supported by Kitch, The Nature and Function of the Patent System, 20 J.L. \& Econ. 265 et seq. - according to which the wider and longer is the scope and duration of a patent granted to a firm, the greater the incentive to invent around this initial invention for that firm, both in its own interest and (indirectly) for the competitors, the third parties and the common good. For a more sceptical point of view on this alleged motivation for property rights (and patents in particular), also as incentives to license, see Reichman, Of Green Tulips and Legal Kudzu: Repackaging Rights in Subpatentable Innovation, in Vaver (ed.), Intellectual Property Rights. Critical Concepts in Law (2006), pp. 83 et seq.

${ }^{45}$ Compare Gilbert E Shapiro, Optimal Patent Length and Breadth, 21 RAND Journal of Economics 106 et seq. (1990) (supporting a narrow, but long patent protection), with Gallini, Patent Length and Breadth with Costly Imitation, ibid., (1992), pp. 52 et seq. (arguing that a 
their competitors do not have the complete know-how or the relevant creativity to achieve the same goals in the same time. In addition, it is often asserted that the more innovation is patented, the more innovation is made available to the public, which is not the case with alternate models grounded in the protection of trade secrets: it would be anyway opposed, on the one hand, that not all innovation - such as many mechanical or electrical devices - is suited for secrecy (due to reverse engineering), and, on the other hand, that secrecy is definitely compatible with patents, as demonstrated by the mixed patent and know-how licences under EC Regulation of April 27, 2004, No 772/2004 (Article 1.1.b). In any case, "the highest incentive for creative innovation $=$ the highest level of protection" is a further corollary inferred from the equation above: a veritable, increasing and inexorable "race-to-the-top" has been established in patent protection ${ }^{46}$, not only in enlarging its boundaries (subject-matter, scope, duration,

long duration of patent protection reduces incentives for productive innovation). See also further references and theories in Gallini $\&$ Scotchmer, Intellectual Property: When Is It the Best Incentive (supra, note 38), pp. 63 et seq.

46 This "race to the top" is clearly allowed and strenghtened by the international provisions, such as Article 1, $\mathbb{S} 1$, TRIPs (Members may only implement, in their law, "more extensive protection than is required by this Agreement"), or Article 19 of the Berne Convention, proclaiming that the minimum standard of protection shall not preclude the making of a claim to the benefit of any greater protection than that which might be granted by legislation in a Country of the Union: however, this legal rule ought to be better matched with the economic mechanism of IP rights, which - as noted before (see supra, text and note 41) - works as an easy and attractive way for the State to enhance this kind of subsidies for creative innovation without making any direct payment like State aids or prizes. Such a mechanism therefore - may work well if privileges are relatively worthwhile and selected, avoiding public choices and granting payments to right holders only by direct users according to a marketbased framework: on the contrary, when IP rights are granted to trivial innovations - such as a double-click by the mouse or very simple images - the State not only hinders, instead of fostering, creative innovation (according to the "anti-commons" doctrine), but also obliges almost every citizen to pay for this, taking the role of a sort of hidden tax-shifting, from a legal point of view, in addition to the frequent "deadweight loss" argument from an economic perspective. This double face of IP rights is perhaps recognizable in the "Rafael Hoteles" case, where the ECJ, case C-306/05, [2006] ECR I-11519 ruled on the one hand, that: "the action by the hotel by which it gives access to the broadcast work to its customers must be considered an additional service performed with the aim of obtaining some benefit", since "it cannot be seriously disputed that the provision of that service has an influence on the hotel's standing and, therefore, on the price of rooms"; and on the other, rejected an argument concerning the private nature of hotel rooms - invoked by Ireland, according to the European Convention for the Protection of Human Rights and Fundamental Freedoms, signed in Rome on November 4, 1950, and in particular Art. 8, which prohibits any arbitrary or disproportionate interference by a public authority in the sphere of private activity - because the customers who benefit from the signal, which they receive, "are under no obligation to pay the authors. Nor can the victim be the hotel since, even though it must be concluded that the hotel is obliged to make such payment, it cannot claim to be a victim of an infringement of Art. 8 of the ECHR in so far as the rooms, once made available to its customers, cannot be considered as coming within its private sphere". Such an ambiguous reasoning is - once again - expressly construed only in order to apply the political statement that a broad interpretation of copyright(s) is "es- 
etc.), but also in lowering the basic requirements for the protection itself, such as the inventive step (which has been gradually decreasing and has finally been reduced to a negative condition of "non-obviousness") ${ }^{47}$. See e.g. Recital No 2 of the EC Directive No 98/44 ("in the field of genetic engineering, research and development require a considerable amount of high-risk investment and therefore only adequate legal protection can make them profitable"), and Recital No 46 ("in view of the fact that the function of a patent is to reward the inventor for his creative efforts by granting an exclusive but time-bound right, and thereby encourage inventive activities, the holder of the patent should be entitled to prohibit the use of patented self-reproducing material in situations analogous to those where it would be permitted to prohibit the use of patented, non-selfreproducing products, that is to say the production of the patented product itself”). Such a corollary is even more palpable in copyright: see e.g. Recital No 9 of EC Directive No 29/2001, 22 May 2001 ("any harmonisation of copyright and related rights must take as a basis a high level of protection, since such rights are crucial to intellectual creation. Their protection helps to ensure the maintenance and development of creativity in the interests of authors, performers, producers, consumers, culture, industry and the public at large. Intellectual property has therefore been recognised as an integral part of property"), related to Recital No 10 ("If authors or performers are to continue their creative and artistic work, they have to receive an appropriate reward for the use of their work,

sential to achieve the principal objective" of EC Directive No 29/2001, which, according to Recitals Numbers 9-10, "is to establish a high level of protection of, inter alios, authors, allowing them to obtain an appropriate reward for the use of their works" (judgment, para. 36).

47 Rightfully criticized by Ghidini, Innovation, Competition and Consumer Welfare [supra, note 27], pp. 73 et seq., supporting a framework in which the incentive paradigm must be dialogic with the main principles of competition and free circulation of goods. See also OECD, Competition, Patents and Innovation, January 8, 2008, DAF/COMP(2007)40, p. 25, available at http://www.oecd.org/dataoecd/26/10/39888509.pdf: "despite the lack of clear evidence that there is a positive relationship between patents and innovation in general, a number of countries began to strengthen their patent systems in the 1980s and have continued to do so (...). For the past several years, some commentators have been raising concerns that too many patents are being issued now, that their claims are too broad, and that the rights they confer on patent holders are too strong. The result, the critics claim, is that innovation is actually being discouraged because it is difficult and costly to identify the patents that might be relevant to an invention and to pay for any necessary licenses (...). Many experts have also suggested that the non-obvious requirement should be strengthened, which would reduce the number of patents being issued". The U.S. Supreme Court tried to tighten the non-obvious criterion in 2007 (KSR Int'l Co. v. Teleflex, Inc., 550 U.S.398, 2007), warning that otherwise innovation might be stifled rather than fostered. But see Weingaertner $\mathcal{E}$ Conrad, Rendez-vous with Obviousness. US Supreme Court Reckons with Patentability Standard in KSR International Co v Teleflex Inc and Lower Courts React, [2008] EIPR 294 et seq.; for a demonstration that weak nonobviousness requirements can lead to less R\&D activity, Hunt, Nonobviousness and the incentive to innovate: an economic analysis of intellectual property reform (1999), Working Papers 99-3, Fed. Reserve Bank of Philadelphia, available at www.philadelphiafed. org/research-and-data/publications/working-papers/1999/wp99-3.pdf. 
as must producers in order to be able to finance this work", for "the investment required to produce products such as phonograms, films or multimedia products, and services such as 'on-demand' services, is considerable. Adequate legal protection of intellectual property rights is necessary in order to guarantee the availability of such a reward and provide the opportunity for satisfactory returns on this investment") ${ }^{48}$ : all of these extremely dogmatic assumptions must - however - be subject to much criticism in order to re-balance once again the framework of the whole system of intellectual property ${ }^{49}$. All that glitters is not gold: one-way policies grounded on over broad or blanket incentives - actually turning into undeserved subsidies ${ }^{50}$ - have been already proven dangerous for the market, the free trade and the public interest in many other fields. Nevertheless, the European Law is firmly standing in the framework of the international IP principles, which support uniquely a "race to the top", according with the dogmatic equations and corollaries above mentioned ${ }^{51}$ : indeed, the Eu-

48 Although nominally "a fair balance of rights and interests between the different categories of rightholders, as well as between the different categories of rightholders and users of protected subject-matter" should be safeguarded (Recital No 31 of EC Directive No 29/2001), ECJ, case C-5/08, Infopaq, [2009] ECR I-6569, has recently re-affirmed that "with respect to the scope of such protection of a work, it follows from recitals 9 to 11 in the preamble to $\mathrm{Di}$ rective 2001/29 that its main objective is to introduce a high level of protection, in particular for authors to enable them to receive an appropriate reward for the use of their works, including at the time of reproduction of those works, in order to be able to pursue their creative and artistic work": that being so, given the requirement of a broad interpretation of the scope of the protection conferred by Art. 2 of Directive No 2001/29, "the possibility may not be ruled out that certain isolated sentences, or even certain parts of sentences in the text in question, may be suitable for conveying to the reader the originality of a publication such as a newspaper article, by communicating to that reader an element which is, in itself, the expression of the intellectual creation of the author of that article. Such sentences or parts of sentences are, therefore, liable to come within the scope of the protection provided for in Art. 2(a) of that directive", even if it is for national courts to ascertain the existence of an intellectual creation through the choice, sequence and combination of those words that an author may express (judgment, paras. 40-47). Compare also these dogmatic assumptions - aimed only at granting an acquisition of private power to producers or to other cultural industries - with the seminal goal of the copyright "vested in authors", as considered by MacMillan, What might Christian Andersen say about Coyright today?, in Porsdam (ed.), Copyright and Other Fairy Tales: Hans Christian Andersen and the Commodification of Creativity (2006), pp. 83 et seq.

49 On property rights and welfare, from the perspective of a general competitive equilibrium under the incentive paradigm, Campbell, Incentives. Motivation and the Economics of Information, 2 nd ed. (2006), pp. 513 et seq.

50 For software and trade mark exploitation too, a fairer calibration is supported by Merges, Who Owns the Charles River Bridge? Intellectual Property and Competition in the Software Industry (1999), p. 37 (available at http://www.law. berkeley.edu/institutes/bclt/ pubs/merges/criver.pdf), "along the lines of patent and copyright, to adjust the incentive to call forth the optimum (or at least desirable) level of this activity, rather than providing a permanent, blanket incentive".

51 As correctly remarked by Stiglitz, Making Globalisation Work, Economic and Social Rev., 39/3 (2008), pp. 182 et seq., "the problem is that the intellectual property regime that was put into the Uruguay trade talks called TRIPs - which means Trade Related Intellec- 
ropean Union has not only already adopted a strict “TRIPs plus” paradigm of protection, but is going to comply soon with the perhaps more rigorous standards of the ACTA ${ }^{52}$ not yet officially disclosed into public sessions, but settled through secret diplomatic conferences by some major Countries outside WIPO or WTO.

\section{How far does the incentive paradigm take us?}

\section{Decreasing requirements for creative innovation in return for increasingly strenghtened exclusivity rights: is there anything wrong with this synallagmatic relationship between Society and authors or inventors?}

First of all, rewards should only be due when substantial and worthwhile works are made. Bounty killers were rewarded only if they took the bad guy "alive or dead" or - like today's bounty hunters - were able to provide all the informa-

tual Property - has nothing to do with trade. The words 'trade related' were simply used to get it into the agreement. It was not a balanced decision and certainly not an agreement that reflected the interests of the developing countries. In fact, TRIPs was so imbalanced that it was even opposed by the Office of Science and Technology Police in the United States and the Council of Economic Advisors that I was on at that time (...). [But] the view of the trade lawyers was that the stronger the intellectual property rights the better, and that is just what we got in the intellectual property agreements at the Uruguay Round". Compare Einhorn, The Impact of the WTO Agreement on TRIPs (Trade Related Aspects of Intellectual Property Rights) on EC Law: A Challenge to Regionalism, CMLR (1998), 1069 et seq., with Kur E Schovsbo, Expropriation or fair game for all? The gradual dismantling of the IP exclusivity paradigm, in Kur \& Levine, Intellectual Property Rights in a Fair World Trade System - Proposal for Reform of TRIPs (2011), pp. 408 et seq.

52 See the European Parliament Resolution of 22 September 2010, on the enforcement of intellectual property rights in the internal market (2009/2178(INI)), adopted by 328 to 245 votes with 81 abstentions, which calls on the Commission, on one hand, "to step up its cooperation with priority third countries with regard to intellectual property and promote a balanced approach in the context of the negotiations on intellectual property under the auspices of the World Trade Organisation concerning intellectual property, particularly in the framework of the Agreement on Trade-Related Aspects of Intellectual Property Rights (TRIPS)"; on the other hand, "to ensure that its efforts to further the negotiations on the multilateral Anti-Counterfeiting Trade Agreement (ACTA) with a view to improving the effectiveness of the IPR enforcement system against counterfeiting are continued with full account being taken of the Parliament's position, in particular as expressed in its resolution of 18 December 2008 on the impact of counterfeiting on international trade, and calls on it to fully inform Parliament on the progress and outcome of the negotiations and to ensure that the provisions of ACTA fully comply with the acquis communautaire on IPR and fundamental rights" (para. 41 and 42). As a matter of fact, the Anti-Counterfeiting Trade Agreement (ACTA) has been promoted since 2006 by USA and Japan (later joined by EU, Switzerland and some other countries): an informal deliberative and predecisional draft has been released only on 2 October 2010, reflecting the outcome of the 11th and final round of the negotiations held in (avaliable at: http://trade.ec.europa.eu/doclib/docs/2010/october/tradoc_146699.pdf). Some delegations have expressed reservations on specific parts of the text. 
tion necessary to lead to his arrest ${ }^{53}$ : no reward is ordinarily granted now, as well as it was in the past, for less relevant information or for acts with no special merit. In other words, lowering the requirements of creative or inventive step in order to incentivise "junk" inventions or "small-coin" (kleine Münze) works is not only contrary to the common sense - since all natural or legal entities have an incentive to innovate per se at any time through ordinary improvements ${ }^{54}$ but also contradictory to the incentive paradigm itself: the paradoxical dictum that "what is worth copying is worth protecting" 55 would have to be reverted, at least, in the sense that "all that is worth protecting can not be copied". Little and almost obvious efforts often deserve no exclusive protection when the innovative author gains the normal advantages of being the first on the market, which would be an adequate reward for a relatively low amount of investment, indeed, such innovations might be the result of simple serendipity or common and routine acts $^{56}$. In some cases, such as in the case of network-based systems, network externalities function adequately to lock-in the intermediate or final users - as well as competitors ${ }^{57}$ and thus to adequately reward the first-mover without intellectual property rights even in the case where more intensive effort has been expended. The example of "Monopoly" is emblematic: the 1923 U.S. patent expired and copyright now protects its graphic layout ${ }^{58}$, but the very

53 Pope, Bounty Hunters, Marshals and Sheriffs. Forward to the Past (1998), pp. 35 et seq.

54 As for patents, compare U.S. Patent No 5.960.411, granted to Amazon for its one-click method for checking out products from the virtual store - discussed by Scotchmer, Innovation and Incentives (supra, note 17), pp. 251 et seq., in light of the incentive paradigm - with E.U. Patents Numbers EP0204933B1 and EP0205766B1, respectively regarding the "inventions" of hinge-lid packets of cigarettes with smoothed and rounded edges as a purported solution for saving materials or pocket tissues and in order to improve handling of the packets.

${ }^{55}$ Ladbroke v. W. Hill, [1964] WLR 273: for scepticism, see Bently and Cornish, United Kingdom, in Geller (ed.), International (supra, note 5), 2008, $\$ 8[1][a]$, p. 93 . See also the more general criticism by Schricker, Farewell to the "Level of Creativity" (Schöpfungshohe) in German Law?, 26 IIC, pp. 41 et seq. (1995).

${ }^{56}$ Contra, see Scotchmer, Innovation and Incentives (supra, note 17), p. 251, also affirming that serendipity-based inventions are made within the framework of laboratories, research teams, etc., so that serendipity must also be "reconciled (...) with an incentive system".

57 "Indeed, some studies show that most firms rely on patents the least among various methods for protecting the returns from their inventions, whereas secrecy, lead time (being first to market) and customer sales and service are used most heavily": OECD, Competition, Patents and Innovation, 8 January 2008, DAF/COMP(2007)40, available at http://www.oecd. org/dataoecd/26/10/39888509.pdf, p. 11. On the lead-time factor, see Kerin, Varadarajan $\mathcal{E}$ Peterson, First-Mover Advantage: a Synthesis, Conceptual Framework, and Research Propositions, in Journal of Marketing, No. 4 (1996), pp. 33 et seq.; on network externalities, Chou, $\mathcal{E}$ Shy, Network effects without network externalities, in 8 International Journal of Industrial Organization 259 et seq. (1990).

58 Also the legal status of the Parker Brothers' trade mark on the game was not settled until the late 1970s. Prof. R. Anspach - the Czech "inventor" of the Anti-Monopoly - fought the Parker Brothers and won the case on appeal in 1979, as the 9th District Court determined that the trademark "Monopoly" was too generic, and therefore unenforceable. However, af- 
idea or the main scheme of the game itself is no longer protected, according to general principles (Article 9.2 TRIPs); notwithstanding the many imitations of the core features of the game and sometimes of its trade name, "Monopoly" still remains the most often played board game in the world ${ }^{59}$. Also the "Lego" affair might be cited: some recent decisions in Europe, unlike prior case law, have denied Lego bricks an extension of the patent or design protection which they previously enjoyed through the provisions against slavish imitation ${ }^{60}$, but the Lego bricks - notwithstanding the existence of many competitors imitating the exact measurements of the interconnecting pins - still reach optimal levels of sales ${ }^{61}$. Finally, the case of patentable software is perhaps more relevant: since 2002 the EC Commission stubbornly tried to pass the proposal for a directive on the patentability of computer-implemented inventions - which, in practice, granted patentability to software as such, insofar as they have a solely technical character - in order to interpret (or even to circumvent) Article 52.2 of the European Patent Convention ${ }^{62}$, in compliance with the U.S. or Japanese Patent Law

ter some pressure from the Parker Brothers' corporate parent (Hasbro), the U.S. Congress passed a statutory amendment in order to protect the longstanding marks, although generic, especially when a secondary meaning was achieved: today, the game's name is still a registered trade mark of Parker Brothers/Hasbro's group, as well as its particular graphic design.

${ }_{59}$ As affirmed in the instruction booklet enclosed with the 70th Anniversary (U.S.) Edition of Monopoly, in which Hasbro cites the statistic that over 750 million people have played Monopoly. Ironically - as well as the intellectual property - a new version of the game played with cards ("Monopoly Deal", derived from the board game Monopoly, produced and sold by the Parker Brothers under license from Hasbro) has a more speculative approach than its ancestor "Landlord's Game", designed by E. Magie in order to promote the land value tax, supported by $\mathrm{H}$. George from the perspective that the economic rent of land should be shared by society rather than being privately owned.

60 Hoge Raad, 20 November 2009, LJN BJ6999, Lego Nederland B.V. c.s v. Mega Brands Inc c.s., in the Netherlands; Court of Cassation, February 29, 2008, No 5437, in Diritto Industriale, 2008, 277, in Italy; BGH, GRUR 2005, 349 - Klemmbausteine III, in Germany.

${ }^{61}$ As reported at Nuremberg Spielwarenmesse (International Toy Fair), 2010: see LEGO's press release, March 4, 2010 (www.lego.com/eng/info/default.asp?page=pressdetail\&contenti $\mathrm{d}=168693$ \& countrycode $=2057$ yearcode $=\&$ archive $=$ false) .

62 According to the main objectives of the Proposal for a Directive of the European Parliament and of the Council on the patentability of computer-implemented inventions, COM/2002/0092final-COD2002/0047, O.J., June 25, 2002, C 151E, p. 129 "the EPO Boards of Appeal and Courts of the Member States have held that computer-implemented inventions can be considered to be patentable when they have a technical character, i.e. when they belong to a field of technology". Therefore, "computer-implemented inventions which meet this condition are not considered to fall under the exclusion in Art. 52(2) as they are considered not to relate to programs for computers 'as such'. In fact, the exclusion has been interpreted by the Board of Appeal of the EPO as relating to those computer-implemented inventions which have no technical character. With regard to what computer-implemented inventions can be said to have a 'technical character', the conclusion to be drawn from the recent 'Controlling pension benefits system' case [T-0931/1995, 8 September 2000] is that all programs when run in a computer are by definition technical (because a computer is a machine), and so are able pass this basic hurdle of being an 'invention'”. As a consequence, under Article 2, a "compu- 
and on the basic leit motiv of the economic incentive for the EU software industry ${ }^{63}$. As is well known, following many years of debate and conflicting amendments, the proposal was rejected on July 6, 2005, by the European Parlia-

ter-implemented invention" was intended "to mean any invention implemented on a computer or similar apparatus which is realised by a computer program": it is self-evident how this tautologic definition of a "software implemented invention" included almost every computer program as such. The same attempts to patent "anything [already?] existing under the sun" might be expected under the EC directive on biotech inventions (see Hüttermann E Storz, A Comparison between Biotech and Software Related Patents, [2009] EIPR 589 et seq.); however, also in the U.S. Law, an opposite and more balanced trend has been reaffirmed by the U.S. Department of Justice through the amicus curiae brief, 29 October 2010, in the appeal trial from the District Court for the Southern District of New York, in the case No. 09-CV4515 (Myriad BRCA Patents), in particular, when clearly stating, at p. 10 et seq., that "the chemical structure of native human genes is a product of nature, and it is no less a product of nature when that structure is 'isolated' from its natural environment than are cotton fibers that have been separated from cotton seeds or coal that has been extracted from the earth" and - therefore - that a mere "isolation", also in the biotech domain, does not transform a product of nature into a man-made invention, eligible for patent protection. For criticism in the name of the incentive paradigm - nevertheless - see, e.g., Tsui, US DOJ Weighs in on Battle over Gene Patents (at http://www.iposgoode.ca/2010/11/us-doj-weighs-in-on-battle-over-genepatents/), arguing that "it is inappropriate for the DOJ to compare isolated genes to mined coals because the haploid human genome contains over 3 billion DNA nucleotides which encode over 20,000 protein-coding genes" and supporting "compelling reasons for concluding that gene patents provide an incentive for investment in biotechnology. The Myriad (MYGN) BRACAnalysis diagnostic test drove revenue up in the first quarter of fiscal 2011 by $7.2 \%$ to $\$ 80.7$ million from $\$ 75.3$ million one year ago. Technology transfer offices are locally set up at university research institutions to facilitate academic researchers in the commercialization process. It is now widely accepted [?!] that if research results are to be translated from the bench-side to bedside, patenting is an imperative process to attract commercial interests for the investment in costly, and often lengthy, clinical trials"; it is anyway admitted by the same scholar that "the DOJ is simply invalidating patents that pertain to naturally occurring DNA sequences alone" and that "the narrowing of patentability could be beneficial to the community by encouraging intellectual scientific research rather than promoting a rat race of genome sequencing". It is remarkable that also under Article 5(3) of EC Directive No 98/44, the specific "industrial application" of a sequence or a partial sequence of a gene is required to be disclosed in the patent application. The Federal Circuit, however, has reversed the decision, inter alia, on the ground of the protection of the investment granted by the patent: Association of Molecular Pathology v. U.S. Patent and Trademark Offic), No. 2010-1406, 8 (Fed. Cir. July 29,2011 ), but the dissenting opinion by Judge Bryson in the case reaffirms the principle above suggested by the Dept. of Justice.

63 According to the main objectives of the proposed directive in question, "patents play an important role in ensuring the protection of technical inventions in general. The basic principle underlying the patent system has proven its efficiency with respect to all kinds of inventions for which patent protection has thus far been afforded in the Member States of the European Community. Patents act as an incentive to invest the necessary time and capital and it stimulates employment. Society at large also reaps benefits from the disclosure of the invention which brings about technological progress upon which other inventors can build". As concluded by Weiss, in Cellini \& Cozzi (Eds.), Intellectual Property, Competition and Growth (2007), pp. 7 et seq., at 16, "it seems unlikely that extending patentable subject matters that are already protected abroad leads to even more investment and more trade”. 
ment in a majority of 648 to 14 votes: notwithstanding the easiness with which the EPO continues to grant (unlawful?) software patents ${ }^{64}$, it cannot be affirmed that software production or its dissemination has been hindered by the lack of a general directive for harmonization, granting EU patent protection to computer programs ${ }^{65}$. As it was aptly remarked, "aggressive, well-funded and asset-rich traders are apt to throw their weight around in the marketplace irrespective of the nature of their intellectual property portfolio. Thus, while

${ }^{64}$ For further reference on how to protect computer programs per se, since the leading cases T-97/0935 and T-97/1173 were decided by the EPO Board of Appeal, see Beresford, Patenting software under the European Patent Convention (2000), pp. 90 et seq.

${ }^{65}$ The proposed directive on the patentability of computer-implemented inventions is also very relevant in demonstrating two other grounds of IP protection under the present framework. As for the "race to the top", the objectives of the proposed EC directive clearly state that much "uncertainty and divergences in legal protection can have a real and negative effect on investment decisions and free movement of goods within the internal market. The most obvious example of this can arise where a product is held to be patentable in the jurisdiction of one Member States and not in another. The competitive environment for innovative products in this situation will be radically different depending upon whether or not they are protected, while unlicensed copies will be prevented from passing across the Community's internal frontiers from Member States where protection has been denied to those where it exists. Companies considering the location of development facilities or the entry into new markets are also likely to be influenced in their decisions by the degree of certainty in the extent to which the local courts would give protection to computer-implemented inventions". Once again, however, the EC response is to grant the greatest extent of protection, not questioning the option of enjoying a full level of harmonization by denying all patent protection to software or at least by imposing common higher requirements for industrial application instead of the tautological "technical character" as such. Accordingly, Recital No 5 of the proposed directive concluded: "therefore, the legal rules as interpreted by Member States' courts should be harmonised and the law governing the patentability of computer-implemented inventions should be made transparent. The resulting legal certainty should enable enterprises to derive the maximum advantage from patents for computer-implemented inventions and provide an incentive for investment and innovation" [Emphasis added]. As for the mere "incentive" paradigm in favour of the incumbent industries, it must be remarked that an apparently "democratic" consultation with the public at large, as well as with Member States, was launched by the Commission on October 19, 2000, for comments on the basis of a paper which was made available on the Internet, grounded in the same protective lines then adopted by the proposed directive: on one hand, indeed, "the individual responses were dominated by supporters of open source software, whose views ranged from wanting no patents for software at all to the 'official' position of the Eurolinux Alliance which is to oppose patents for software running on general-purpose computers. On the other hand, submissions broadly in support of the approach of the consultation paper tended to come from regional or sectoral organisations representing large numbers of companies of all sizes, such as UNICE, the Union of Industrial and Employer's Confederations of Europe, EICTA, the European Information and Communications Technology Industry Association, and the European IT Services Association. There were also individual large organizations, other industry associations and IP professionals. Thus although the responses in this category were numerically much fewer that those supporting the open source approach, there seems little doubt that the balance of economic weight taking into account total jobs and investment involved is in favour of harmonisation along the lines suggested in the paper" [Emphasis added]. 
corporations such as IBM and Microsoft have built up remarkable dominance within their markets on the strength of patent rights even though their core sectors are characterised by technological complexity and high market entry costs, other businesses such as McDonald's, Wal-Mart, Coca Cola and Starbucks have achieved an equally remarkable degree of penetration and market share in sectors where barriers to market entry are low or negligible and the cost of market entry is relatively cheap, and have done so without the benefit of the exclusionary monopolies conferred by patents" ${ }^{36}$. In most of the examples mentioned above, however, the "selling power" of the trade mark is probably enough of a weapon to protect these businesses from imitators, regardless of the existence of patent or copyright protection against free riders (especially in case of the food and beverage industry, in which copyright or patent protection might be more difficult to achieve) ${ }^{67}$; moreover, in some of these cases - such as with Coca Cola - stronger exclusive protection might be obtained by secrecy ${ }^{68}$, which is virtually perpetual at least until someone lawfully unveils the relevant formula or the underlying process (also, e.g., in the case of other intellectual creations, such as for the secret source-code of computer programs). It is just to encourage the dissemination of innovations and to avoid temporary or even perpetual trade secrets that the patent system has been traditionally deemed to be the best incentive for ensuring the inventor's individual profit, on the one side, whilst also providing the best incentive for the latter to make these creative innovation available to the public, on the other side: from the time of the early and basic statement in the French Patent Law of $1791^{69}$, the requirement of complete and clear disclosure of inventions has become a main ground for validity of patents all over Europe, under Articles 83 and 138.1.b of the European Patent Conven-

66 Phillips, A Spanner in the Works - Or the Spanner that Works? Patents and the Intellectual Property System, in Takenaka (ed.), Patent Law and Theory (supra, note 43), p. 152.

${ }^{67}$ See Cheng, Copyright protection of haute cuisine: recipe for disaster?, [2008] EIPR 93 et seq.; of course, a more shared kind of intellectual property - similar to the original collective trade marks - must also be acknowledged for geographical indications under TRIPs, including, in Europe, the "traditional specialities guaranteed": see, e.g., EC Regulation No $1204 / 2008$, December 3, 2008, on the entry of certain names in the Register of traditional specialities guaranteed, provided for in the basic EC Regulation No 509/2006.

68 Nonetheless - according to Grandstrand, The Economics and Management (supra, note 21), p. 44 - the more a firm grows, the more its market power becomes independent on its prior IP rights: "Coca-Cola, for example, could probably lose its secret formula and still survive (...). In summary, the IPR system in general, and the patent system in particular, has been neither necessary nor sufficient for technical and/or economic progress at country and company level historically".

69 See also Art. 12.2.a of the Paris Convention: each country of the Union undertakes to establish a special industrial property service and a central office for the communication to the public of patents, utility models, industrial designs, and trademarks; this service shall publish a periodical journal, which shall regularly make available to the public - inter alia the names of the proprietors of patents granted, but only "with a brief designation of the inventions patented". 
$\operatorname{tion}^{70}$. This principle has correspondingly been extended to the other technical issues, such as plant varieties (Article 50.f of the EC Regulation No 2100/94), or as topographies (Article 4.1 of the EC Directive No 87/54), and this is a frequent reason that leads some scholars to support a greater extension of the patent system to petty or lower forms of invention ${ }^{71}$ : the more extensively innovative knowledge to be covered by patents is fostered, the wider dissemination to the public is provided for, in comparison to alternate incentives aimed at avoiding free riding (such as by secrecy) $)^{72}$.

\section{The incentive to disclose an invention in return of patent rights: does this basic consideration (quid pro quo) of the contract between society and inventors still work?}

The conclusions reported above - however - seem at least too optimistic, if not wrong, since they presume a static and monistic scenario; in addition, if secrecy is definitely an obstacle for fostering the dissemination of innovative knowledge, this static and monistic favour, which is also granted for trivial or wide patents, risks revealing itself as almost a contradiction in terms ${ }^{73}$. During the lifetime of

70 Under Art.138.1.b, a European patent may be revoked with effect for a Contracting State if the patent does not disclose the invention in a manner sufficiently clear and complete for it to be carried out by a person skilled in the art, according the principle laid down in Art. 83 (R. Singer \& M. Singer, The European Patent Convention. A Commentary (1995), pp. 336 et seq. and 831 et seq.). See also TRIPs, Art. 29 ("Members shall require that an applicant for a patent shall disclose the invention in a manner sufficiently clear and complete for the invention to be carried out by a person skilled in the art and may require the applicant to indicate the best mode for carrying out the invention known to the inventor at the filing date or, where priority is claimed, at the priority date of the application"). In the WTO too, disclosure is considered to be the quid pro quo in exchange for the grant of patent protection: Reyes-Knoche, in Stoll, Busche \& Arend (eds.), WTO - Trade-Related Aspects of Intellectual Property Rights (supra, note 28), pp. 524 et seq.

71 See e.g. the "keiretsu model" supported by Kieff, On the economics of patent law and policy, (supra, note 43), pp. 50 et seq., according to which weak patents ordinarily granted by the Japanese patent system allow the larger conglomerate enterprises "to communicate with each other" through "skirmish" legal battles, thus mitigating all trust problems and disseminating patented knowledge among competitors.

72 See the arguments reported in $O E C D$, Competition, Patents and Innovation (supra, note 47), p. 25: "a weak inventive step requirement has the benefit of encouraging the disclosure of even small technological advances. On the other hand, knowing that competitors can obtain patents on even minor improvements they may make to an innovation may persuade inventors to choose secrecy over patents. If a substantial inventive step is required, companies are encouraged to set loftier goals for their R\&D programs, but smaller advances will not be disclosed. In any event, one thing scholars seem to agree on is that the optimal design of patent policy depends on how easy or difficult it is for patent holders to use licensing to rearrange and exercise their rights".

73 As stressed as well by OECD, Competition, Patents and Innovation (supra, note 56), p. 25, according to which, many of the economic models "assume that innovation is a discrete process that leads to one separate invention at a time. Often, however, innovation is cumula- 
a patent, in practice, disclosure is mainly relevant for making exclusive protection more effective for the patentees' sake, rather than for dissemination for the benefit of third parties: on one hand, under Article 69 of European Patent Convention, description and drawings are intended to aid the interpretation of claims ${ }^{74}$, which, in turn, determines the extent of the protection; on the other hand, Article 67.1 takes the publication of patent applications into account only in order to ensure the effectiveness of protection ${ }^{75}$. In this context, a particular meaning assumes the conflict between independent inventors under Article 54 EPC, according to which the state of the art shall be held to comprise everything made available to the public, by means of a written or oral description, by use or in any other way, before the date of filing of the European patent application $(\$ 2)$, but the content of European patent applications as filed - the dates of filing of which are prior to the date referred to in para. 2 and which were published on or after that date - shall be considered to be additionally comprised in the state of the art $(\$ 3)$. This conflict arises once again from a static consideration of disclosure only as a means for rewarding the prior inventor through a default period of eighteen months from the date of filing - or, if priority has been claimed, from the date of priority - while the invention remains totally secret and may be increasingly refined in order to become adequately clear and complete (Article 93.1.a) $)^{76}$ : once again, the conflict between two identical inventions - which are both "new" because they are not included in the state of the art under Article 54.2 - is solved according to the basic EU "first-to-file" rule. Needless to say, whether this rationale is reasonable and well grounded cannot be disputed on the

tive in the sense that it builds on previous inventions. Thus, R\&D may be undertaken for the purpose of improving an existing technology or finding a new application for it, rather than creating an entirely new and independent invention. Incorporating that consideration adds a number of intricacies to the problem of optimal patent design". It is however questionable that all inventions are fit for secrecy: supra, text and note 45.

74 Which is another basic principle in European Law: compare Art. 69 EPC with Art. 8 of the Convention on the Unification of Certain Points of Substantive Law on Patents for Invention, signed by Member States of the Council of Europe on November 27, 1963, in Strasbourg, already providing that the description had to disclose the invention in a manner sufficiently clear and complete for it to be carried out by a person skilled in the art. In the light of the incentive paradigm, Scotchmer, Innovation and Incentives (supra, note 17), p. 156: "disclosure plays the particularly important role of accelerating progress, especially by giving a boost to rivals". See also Anton \& Yao, The Sale of Ideas: Strategic Disclosure, Property Rights, and Contracting, in 69 Review of Economic Studies 513 et seq. (2002).

75 Even before publication, the disclosure, the drawings and the claims, as well as the other relevant requirements of the application, may be communicated to individual competitors who are already using the invention, in order to anticipate absolute protection at the date of the communication: Art. 67.3.b EPC: R. Singer E M. Singer, The European Patent Convention (supra, note 70), pp. 245 et seq.

76 The European Patent Office publishes the European patent application before the expiry of the eighty-months period only at the request of the applicant (Art. 93.1): R. Singer $\mathcal{E}$ M. Singer, The European Patent Convention (supra, note 70), pp. 422 et seq. 
grounds of legal certainty, although it might be profoundly put into question, on the contrary, for providing such a long period of secrecy which might allow applications concerning simple layouts or sketches for inventions yet to be materialised in a way that does not provide any reasonable incentive to the future patentees $^{77}$. Once again, the optimistic perspective that the patent system can avoid a "threat of exclusion" ", by acting "like a beacon in the dark, drawing to itself all those interested in the patented subject matter" and "providing a focal point, or beacon", in order to help "each of these individuals to find each other", thanks to disclosure and publication provisions, should take into account the practical reality of this "black-hole" of eighteen months, capable of destroying the novelty of the "second" invention under Article 54.3 as a maelstrom along the navigated route to the (supposed) light-house. This "one-way incentive" for the prior applicant creates strong disincentives for all other inventors, who are no longer able to know the previous state of the art for one year and half, and, during this time, must fear a phantom application which could kill their (already filed) ones - as well as all the investment which has been undertaken in the meanwhile - suddenly coming from out of nowhere ${ }^{79}$ : in practice, the main utility of disclosure for competitors is demonstrated after the expiration of the patent, i.e. when the technology may be useless or obsolete, but when the ancillary know-how might still be secret. Indeed, pending patent's life, dissemination of patented knowledge does not necessarily permit third parties to test the invention or make improvements: while the experimental use of patented subject-matter is not yet expressly stated among the principles of EU patent law - only being laid down for plant varieties in Article 15.b-c of EC Regulation No 2100/94 or indirectly quoted in Article 13.3.b of EC Directive No 98/44 ${ }^{80}$ - all derivative innovations have been totally prohibited from being used, absent the prior rightholder's consent, by Article 31.l(i), TRIPs, unless "the invention claimed in the second patent shall involve an important technical advance of considerable economic significance in relation to the invention claimed in the first patent", so that a compul-

77 As remarked by OECD, Competition, Patents and Innovation II, April 10, 2010, DAF/ COMP(2009)22, (available at http://www.oecd.org/dataoecd/26/33/45019987.pdf), p. 8 moreover - due to such a long period of patent pending, there has been "a significant increase in the number and complexity of patent applications filed in the world's major patent agencies, resulting in a greater backlog and substantially longer pendency periods. More applications pending for longer periods have led to greater uncertainty about which inventions are and will be protected by patent rights (...). A number of strategies that are potentially harmful to both competition and innovation have been adopted to take advantage of the uncertainty created by growing backlogs and longer pendency periods, including strategic uses of divisionals".

${ }_{78}$ Kieff, On the economics of patent law and policy (supra, note 43), p. 42.

79 On the dangerous risks of these "submarine patents" for the incentive to subsequent innovators, see Boldrin E Levine, Against Intellectual Monopoly (supra, note 41), pp. 84 et seq.

${ }^{80}$ A general "research exemption" in EU patent law is only laid down by Art. 27(b) of the Agreement on Community patents, done at Luxembourg on December 15, 1989 (O.J. 30 December 1989, L 401), not (yet?) entered into force. 
sory license may be applied for ${ }^{81}$. Besides this static establishment, in comparison to a more dynamic and competitive market, the monistic incentive to the sole patentee for commercialising (or not) a patented subject-matter is shown by the substantial abrogation of the burden to work an invention: once commonly sanctioned by forfeiture of the patent in many European Countries ${ }^{82}$, today the lack of adequate work gives rise only to a (possible) application for a (non-exclusive and) compulsory license by a competitor - on the grounds of "its individual merits" under the provision laid down in Article 31, TRIPs - that seems, however, designed as a hard obstacle course which has to be proven a very weak or ineffective incentive for third parties to disseminate the invention if the right holder does not do so voluntarily ${ }^{83}$. Some theories have asserted that a proprietary regime in intangible assets - such as patentable subject-matter - is the best incentive per se not only for the creation, but also for the dissemination of innovative knowledge: from this perspective, property rules allow both greater certainty in scope, duration, enforcement, etc., than liability or contract rules ${ }^{84}$ and a more centralised control over the relevant information, which would create a stronger (when not the strongest) incentive for the right holder to disseminate it by himself or through licensees ${ }^{85}$. Once again, however, this perspective seems too optimistic and even naive, as it assumes positive behaviour on the part of the proprietor, as the default rule, which is quite far from being proven: this standpoint, as a matter of fact, must face what behavioural theories identify with the more usual decision-makers' attempts to "satisfice rather than optimize" the rent ${ }^{86}$, as well as the antitrust rules on patent and intellectual property against the opportunistic practices undertaken by the proprietors of intangible assets demonstrate. If the right holders were so encouraged to disseminate their assets on their own or through licensees, therefore creating the greatest chance of development

81 In addition, Art. 31.1, TRIPs requires that (ii) the owner of the first patent shall be entitled to a cross-licence on reasonable terms to use the invention claimed in the second patent; (iii) the use authorized in respect of the first patent shall be non-assignable except with the assignment of the second patent.

82 Cancellation may remain only with respect of trade marks, if not adequately used for three years: Art. 19, TRIPs. Moreover, the TRIPs provision and its enactment in EU Law seems construed more to ensure fees and other guarantees in favour of the patentee than to promote the application for the compulsory license by competitors: Eikermann, in Stoll, Busche \& Arend (eds.), WTO - Trade-Related Aspects of Intellectual Property Rights (supra, note 28), pp. 567 et seq., with further references.

${ }^{83}$ Under an incentive rationale for competitors and general welfare, also in the law of copyright, Gallagher, Copyright Compulsory Licensing and Incentives, in Towse (ed.), Copyright in the cultural industries [supra, note 8], pp. 85 et seq.

${ }_{84}$ Kieff, On the economics of patent law and policy (supra, note 43), p. 43 s., who however, at 13 , admits that some liability rule treatment must be available to avoid total restriction of access under property rules.

${ }^{85}$ Kieff, On the economics of patent law and policy (supra, note 43), pp. 54 et seq.

${ }^{86}$ Kieff, On the economics of patent law and policy (supra, note 43), p. 14, with further references. 
and of dynamic competition, the whole EC Regulation No 772/2004, of 27 April $2004^{87}$, on the application of Article 81.3 of EC Treaty to technology transfer agreements - with its guidelines and its previous releases ${ }^{88}$ - should be merely residual: according to Recital No 5, such agreements are indeed aimed so as to "usually improve economic efficiency and be pro-competitive as they can reduce duplication of research and development, strengthen the incentive for the initial research and development, spur incremental innovation, facilitate diffusion and generate product market competition". In view of such incremental innovation by licensors or competitors - as happens more frequently nowadays than in past periods of huger creative destruction, according to Schumpeter ${ }^{89}$ - this specific protection must therefore be granted to preserve the licensee's incentive to develop derivative innovations and not just to ensure the licensor has the incentive to seek the maximum amount of rent from any improvement which is more or less severable: according to further Recital No 14 of the Regulation, thus, "in order to protect [the licensee's] incentives to innovate and the appropriate application of intellectual property rights, certain restrictions should be excluded from the block exemption. In particular, exclusive grant back obligations for severable improvements should be excluded" $" 90$. If white-listed clauses, nevertheless, have

${ }^{87}$ E.C.O.J., 27 April 2004, L 123, pp. 11 et seq., replacing EC Regulation No 240/96 of January 31, 1996.

${ }^{88}$ Guidelines on the application of Art. 81 of the EC Treaty to technology transfer agreements (E.C.O.J., April 27, 2004, C 101); for a comparative perspective on U.S. and E.U. rules on IPR licensing agreements, see Zabbo, in Lidgard \& Atik (eds.), The Intersection of IPR and Competition Law (supra, note 32), pp. 111 et seq.

${ }^{89}$ See OECD, Competition, Patents and Innovation (supra, note 56), p. 47: "what has come to be known as the Schumpeterian view is that big, dominant firms are more likely to innovate than smaller ones that lack market power, but also that innovations are 'gales of creative destruction' that render market power ephemeral in high-innovation industries. The opposing view is that competition promotes more innovation because entrenched market power makes managers less inclined to spend money on developing new technologies, while firms facing greater competition have more to gain by innovating". However, while the "competition agencies tend to adopt the latter view", according to the OECD, it is still questionable "whether the presumption that competition is better for innovation than monopoly is valid". See Gilbert, Looking for Mr. Schumpeter: Where Are We in the Competition-Innovation Debate?, in Jaffe, Lerner and Stern (eds.), Innovation Policy and the Economy, Vol. 6 (2006), pp. 159 et seq.

90 As a rule - according to the Guidelines above mentioned (supra, note 88), - Art. 81(1) of the EC Treaty “only applies where the agreement reduces the licensee's incentive to improve and exploit his own technology " (para. 116). Thus, "an obligation to grant the licensor an exclusive licence to severable improvements of the licensed technology or to assign such improvements to the licensor is likely to reduce the licensee's incentive to innovate since it hinders the licensee in exploiting his improvements, including by way of licensing to third parties. This is the case both where the severable improvement concerns the same application as the licensed technology and where the licensee develops new applications of the licensed technology. According to Art. 5(1)(a) and (b) such obligations are not block-exempted. However, the block exemption does cover non-exclusive grant back obligations in respect of severable improvements. This is so even where the grant back obligation is non-reciprocal, i.e. only 
effects that are incompatible with Article 81.3 of the Treaty, they should also be withdrawn from the benefit of the block exemption: "this may occur in particular where the [licensee's] incentives to innovate are reduced or where access to markets is hindered" (Recital No 16) ${ }^{91}$. A similar incentive to access and exploitation for all co-venturers of $\mathrm{R} \& \mathrm{D}$ agreements is deemed essential for the exemption laid down in Regulation No 2659/2000, of 29 November 2000: under Article 3.2, "all the parties must have access to the results of the joint research and development for the purposes of further research or exploitation (...)"92. Without prejudice to this requirement, "where the research and development agreement provides only for joint research and development, each party must be free independently to exploit the results of the joint research and development and any pre-existing know-how necessary for the purposes of such exploitation. Such right to exploitation may be limited to one or more technical fields of application, where the parties are not competing undertakings at the time the research and development agreement is entered into". The link with the incentive paradigm in IP law is clearly stated in Article 3.4: "any joint exploitation must relate to results which are protected by intellectual property rights or constitute knowhow, which substantially contribute to technical or economic progress and the results must be decisive for the manufacture of the contract products or the application of the contract processes". However, the trade-off between incentives for exclusive rights and incentives for access to third parties is still classified under the sole incentive paradigm: in other words, the possibilities of licensees, co-

imposed on the licensee, and where under the agreement the licensor is entitled to feed-on the severable improvements to other licensees. A non-reciprocal grant back obligation may promote innovation and the dissemination of new technology by permitting the licensor to freely determine whether and to what extent to pass on his own improvements to his licensees. A feed-on clause may also promote the dissemination of technology because each licensee knows at the time of contracting that he will be on an equal footing with other licensees in terms of the technology on the basis of which he is producing” (para. 109). See also Tuyet Nguyen, Grant-back Obligations, in Lidgard \& Atik (eds.), The Intersection of IPR and Competition (supra, note 32), pp. 142 et seq.

91 On the contrary - according to the Guidelines above mentioned (supra, note 88), at para. 121 - Arts. 4 and 5 of the Regulation No 772/2004, respectively containing the list of strict restrictions and excluded restrictions, aim at ensuring that block exempted agreements "do not reduce the incentive to innovate, do not delay the dissemination of technology, and do not unduly restrict competition" between the licensor and licensee or between licensees. See Brocas, Vertical integration and incentives to innovate, in 21 International Journal of Industrial Organization pp. 457 et seq. (2003).

92 Ritter, The New Technology Transfer Block Exemption under EC Competition Law, in 3 Legal Issues of Economic Integration pp. 161 (2004); Korah, Draft Block Exemption for Technology Transfer, (2004) 25 European Comp. L. Rev. 247; Treacy \& Heide, The New EC Technology Transfer Block Exemption Regulation, [2004] EIPR 414 et seq.; for a comparative perspective between U.S. and EU rules, Feil, The New Block Exemption Regulation on Technology Transfer Agreement in the Light of the U.S. Antitrust Regime on the Licensing of Intellectual Property, 36 IIC 31 et seq. (2005). 
venturers, etc., to access technology is mainly expressed, in turn, as an incentive itself, making it more difficult to escape from this paradigm or to join the (perhaps) more appropriate dichotomy between a more significant "incentive vs. access paradigm" 93 , as proposed. Moreover, under such a strict reward theory, free or at least compulsory access to patented technology by third parties - other than contracting parties, like licensees, co-venturers, etc. - still seems hyper-restricted even in cases involving the fair use of the invention, such as personal or experimental uses, through Article 30 TRIPs $^{94}$, which provides that that legitimate interests of the third parties may only be "taken into account" if they "do not unreasonably conflict with a normal exploitation of the patent and do not unreasonably prejudice the legitimate interests of the patent owner": between a static protection for incumbents and a more dynamic incentive for developing uses by third parties - as observed in the above mentioned case of derivative patents - the odds are still stacked in favour of the former ${ }^{95}$. It might be objected that this choice fully complies with the basic principles of patent law, shielding the first-to-file firm even if it is a small business under competitive attack by third parties with great market power, who intend to invent around and to fence in the first firm's chances of commercialization or development: this situation might, indeed, come to pass. However, one might comment - on one side - that, by this way, small-size entrepreneurs are also boosted to grant licences for deri-

93 Compare Lunney jr., Reexamining Copyright's Incentives-Access Paradigm, 49 Vanderbilt Law Rev. 483 et seq. (1996), with Kieff, On the economics of patent law and policy (supra, note 43), p. 35, discussing the trend to deem the reward no longer a tool, but the main goal, in patent as well as in copyright. More recently, see Barnes, The Incentives/Access Tradeoff, 9 Northwestern J. Tech. and Int. Prop., 96 (2010).

${ }^{94}$ Reyes-Knoche, in Stoll, Busche \& Arend (eds.), WTO - Trade-Related Aspects of Intellectual Property Rights (supra, note 28), pp. 541 et seq., at 543, however reminds - after the "Canada - Pharmaceutical Patents", case WT/DS114/R - that "legitimate interests" are intended to be broader than strict legal interests. An attempt to interpret this provision in order to allow Europe or other countries to be free to set their own standards of "legitimate interests of the patent owner" or "normal exploitation", by Remiche, Marchandisation et brevet, in Vivant (ed.), Propriété intellectuelle (supra, note 39), pp. 132 et seq., on the contrary, seems probably to be going too far and not taking into account the WTO's tight control on the enforcement of TRIPs under Arts. 68 and 64(3) of the Agreement.

95 The very broad Watt-Boulton patent of 1769 - protecting J. Watt's mainstream invention for "a method of lessening the consumption of steam and fuel in fire engines" (see supra, text and note 23) - left "no room for inventing around. Armed with such a patent, Watt could keep his monopoly over the steam engine industry for about 30 years, as he defeated all challenges in the courts. Watt also refused to grant licences. Hence he established an absolute monopoly on the market. When the patent lapsed in 1800, in only a few month's time there was a blossoming of improvements put on the market by competitors, which had been waiting for years in the workshops": by these words Guellec, Patent Design, in Guellec E van Pottelsberghe de la Potterie, The Economics of the European Patent System. IP Policy for Innovation and Competition (2007), p. 141. This example should be enough to reject all of today's economic theories on "prospect rights" or "creative destructions" also in EU patent law: see again Boldrin E Levine, Against Intellectual Monopoly (supra, note 41), pp. 2 et seq. 
vative solutions with no need for antitrust remedies grounded in market power ${ }^{96}$ and without further legal or economic incentives for dissemination; and - on the other side - that apart from any antitrust consideration, an incentive paradigm for creating or protecting innovation through exclusive rights under IP laws must be balanced with incentives to disseminate and incremental innovation from a more general and agnostic perspective ${ }^{97}$ independent from the nature of the firm involved. Fostering and strengthening the small-medium enterprises is indeed an aim to be achieved by different means: e.g. by public actions for making patent fees a less burdensome item on SME budgets - in comparison to the more wealthy conglomerate firms ${ }^{98}$ - or for supporting SMEs in IP transfer agreements.

96 Assuming that these derivative solutions - in a strict legal sense - infringe the small entrepreneur's patent, otherwise, of course, a license need not be granted. See Scotchmer, Innovation and incentives (supra, note 17), p. 156: "to enhance (or to create) incentives for a prior innovation, follow-on innovations should be infringing, which will allow the prior innovator to share the profit through licensing, and may also avoid competition. If the follow-on product infringes the prior patent, then the incentives to develop it can be protected with an exclusive license on the prior patent even if the follow-on product is not itself patentable. However, this strategy will not work if the time between inventions is too long or if licenses cannot be made ex ante before costs are sunk".

97 On this point, compare Kieff, On the economics of patent law and policy (supra, note 43), p. 55. According to Art. 31 TRIPs, the owner of the first patent shall be entitled to a crosslicence on reasonable terms to use the invention claimed in the second patent, involving a virtuous circle of reciprocal innovation (but - as already remarked - only if and when the following patentee has successfully challenged the procedure to obtain a compulsory license, similar to an obstacle course, laid down in the same Agreement).

98 See the Communication from the EC Commission, A“Small Business Act" for Europe, of 25 June 2008, COM(2008) 394 final, para. VIII: the EU and Member States "should encourage investment in research by SMEs and their participation in R\&D support programmes, transnational research, clustering and active intellectual property management by SMEs". To translate this principle more into practice, the EC Commission "will seek to support SME participation in knowledge transfer, partly through the launching of a pilot project to help fund the commercialisation of intellectual property" and "will encourage an active participation of SMEs in the framework of the activities carried out by the European Institute of Innovation and Technology ('EIT'), to enable them to benefit from the knowledge transfers fostered by the EIT". At para. X, moreover, "in order to help SMEs benefit fully from the opportunities offered by globalisation, particular attention has to be paid to improving access to procurement markets and enforcement of intellectual property rights, ensuring fair competition, as well as facilitating market access”. As for public funds, finally, EU and Member States should create an environment within which the entrepreneurs and family businesses can thrive "and entrepreneurship is rewarded": a set of new legislative proposals would be guided by the "Think-Small First" principle, such as a general block exemption regulation on State aids ("GBER"). For these statements, see the introduction of the Communication in question $(\mathbb{S} 3)$. On this point, see Lanjouw E Schankerman, Protecting Intellectual Property Rights: Are Small Firms Handicapped?, in Journal of Law and Economics XLVII (1), (April 2004), pp. 45 et seq. 


\section{Does the access/dissemination paradigm still counterbalance}

the right holders' interests or has it been "internalised" in the incentive paradigm itself?

The statutory reference to the "incentive paradigm" in the EU regulation on technology transfer agreements and its guidelines in order to provide a legal solution for transactions between licensor and licensee(s), may not be surprising after the EU approach has claimed to have turned from legal to economic in this subject-matter ${ }^{99}$ : from the XVIII Century agreements between landlords and farmers or other workers in agriculture ${ }^{100}$, this paradigm has remained fundamental for many economic models of principal-agent relationships - licensing included ${ }^{101}$ - and especially for making clear how the "incentive contracts" work when the principal (such as the right holder) has no chance to check ex ante or expost the actions undertaken by the agent (such as the licensor), as well as his/her information level, so respectively giving rise to "adverse selections" or "moral hazards"102 in these asymmetrical agreements. Nevertheless, at first sight, many of these models seem quite unsatisfactory, since, on one hand, they are mainly construed from (and for) contracts; because, on the other hand, the more these theories are formalised into theoretical formulae, implying arbitrary notions, backgrounds or hypotheses, the more they risk being far removed from legal reality, which is too varied to be captured by the fixed terms of equations $^{103}$. For its part, the economic literature on the incentive paradigm in pat-

${ }^{99}$ See Recital No 4 of the Regulation No 772/2004: “it is appropriate to move away from the approach of listing exempted clauses and to place greater emphasis on defining the categories of agreements which are exempted up to a certain level of market power and on specifying the restrictions or clauses which are not to be contained in such agreements. This is consistent with an economics-based approach which assesses the impact of agreements on the relevant market"; according to this point of view, "it is also consistent with such an approach to make a distinction between agreements between competitors and agreements between non-competitors."

100 Laffont $\mathcal{E}$ Martimort, The Theory of Incentives: The Principal-Agent Model (2003), pp. 8 et seq.

101 Macho-Stadler E Pérez-Castrillo, An Introduction to the Economics of Information. Incentives \& Contracts (1997), pp. 75 et seq. and 149 et seq.; Scotchmer, Innovation and incentives (supra, note 17), pp. 162 et seq.

102 Macho-Stadler E Pérez-Castrillo, An Introduction (supra, note 101), pp. 9 et seq.; Laffont $\mathcal{E}$ Martimort, The Theory of Incentives (supra, note 100), pp. 82 et seq. and 145 et seq., remarking at p. 151: "indeed, only the agent's participation constraint matters for the principal, because the agent can be forced to exert a positive level of effort. If the agent were not choosing this level of effort, his deviation could be perfectly detected by both the principal and the court of law. The agent could be heavily punished, and the court committed to enforce such a punishment".

${ }^{103}$ See, e.g., the so much emphasized formal model for the most efficient copyright protection by Landes E Posner, The Economic Structure of Intellectual Property (supra, note 29), pp. 71 et seq., which is explicitly construed - in order to be tractable - through "several simplifying assumptions: that creators and copiers produce quality-adjusted copies that are perfect 
ents or in other IP rights has constantly stressed inter alia the trade-off between the pros of the exclusive rights and the cons of the deadweight loss for third parties - from new-coming developers to end-users or to society as a whole - but has neither reached shared models, nor unequivocal conclusions, all depending on variable factors, such as the existence of a competitive framework (or not), the licensing available, etc. ${ }^{104}$; moreover, what is more "efficient" in economics is not necessarily "fairest" from a legal perspective, since the basic grounds for justice should always include a balance of the rights that everyone is due ${ }^{105}$.

substitutes, that demand is not subject to uncertainty, that the cost of an expressive work, and that the marginal costs of creators, though not of copiers, are constant"; "author", "creator" and "publisher" are deemed indifferent; the level of copyright protection is denoted by $z \geq 0$, "so that $z=0$ signifies no copyright protection and $z=1$ signifies complete protection" when no copy is permitted without the right holder's consent. "The amount of copyright protection depends on such things as how alike two works must be before infringement will be found, the elements in a work that are protected, the duration of protection and the efficacy and cost of enforcement": accordingly, all these factors are subsumed in the "single index of copyright protection, $z$ ", at 71 , text and footnote 3 . Not only does it seem quite difficult to incorporate all the more varied and complex legal aspects of copyright protection or infringement analysis into mere algebric terms, but it is perhaps even impossible to translate into economic values all the other relevant ethical or behavioural aspects of the factors involved: in particular, it seems very hard to find a demand not subject to uncertainty in this field, since the uncertainty on this side is a basic principle of all creative activities (Caves, Creative industries (supra, note 3), pp. 2 et seq.), so that all these formal exercises and models appear to be more created in a laboratory than corresponding to legal reality. For criticism of the Landes \& Posner model, especially in the information society, see Hakfoort, Copyright in the Digital Age: the Economic Rationale Revisited, in Towse (Ed.), Copyright in the cultural industries (supra, note 8), pp. 63 et seq.; also the economics-based approach in the Regulation No 772/2004, claiming to avoid all lists of (legal) clauses to be exempted, has not prevented these lists from necessarily coming back from the rear in Art.s 4 ("hardcore restrictions", excluding the whole agreement from the exemption) and 5 (single clauses excluded from the exemption) of the Regulation, if the purpose of providing "adequate legal security" for undertakings - affirmed as well in Recital No 4 - had to be fulfilled.

104 Gallini E Scotchmer, Intellectual Property: When Is It the Best Incentive (supra, note 38), pp. 70 et seq.; see also the Guidelines on the application of Art. 81 of the EC Treaty to technology transfer agreements (supra, note 88), para. 9 ("indeed, licensing as such is procompetitive as it leads to dissemination of technology and promotes innovation. In addition, even licence agreements that do restrict competition may often give rise to pro-competitive efficiencies, which must be considered under Art. 81.3 and balanced against the negative effects on competition. The great majority of licence agreements are therefore compatible with Art. 81").

${ }^{105}$ As is also stated by Art. 7 TRIPs: the protection and enforcement of intellectual property rights should contribute to the promotion of technological innovation and to the transfer and dissemination of technology, to the mutual advantage of producers and users of technological knowledge and in a manner conducive to social and economic welfare, and to a balance of rights and obligations. According to Art. 8 too, it has been specifed - even in the WIPO framework - that, "when interpreting TRIPs provisions in their context and in the light of its object and purpose, it will be necessary, to adopt a more balanced approach that weighs the interests of rights holders against other competing public interests, such as educational and developmental concerns. In other words, it would be mistaken to adopt the maximalist 
From a legal perspective, a fair balance between providing incentive to innovative creators and allowing access for competitors or the public to creative innovations was originally struck by creating limits on conditions (such as possible formalities), requirements (novelty, originality, etc.), scope or duration required

pro-rights view referred to under the first dot point above", arguing from the beginning of the preamble, along with the declaration that "intellectual property rights are private property rights", that TRIPs would be concerned only with maximizing the protection of IPRs - as with Berne - and that such a maximalist pro-rights interpretation should be taken (WIPO Study on Limitations and Exceptions of Copyright and Related Rights in the Digital Environment, 5 April 2003, SCCR/9/7, available at: http://www.wipo.int/edocs/mdocs/copyright/en/sccr_9/sccr_9_7.pdf, p. 48). It would be however deceptive to deny that the maximalist approach above mentioned is or was not the original rationale for the TRIPs Agreement, as demonstrated both by its drafting and final wording (explicitly including all the most relevant Berne+Paris provisions): see supra, text and note 51 . Three different justifications for a theory of justice, not only grounded on labour protection or efficiency, are developed by Sen, The Idea of Justice (2009), p. 13 et seq, questioning who should own the flute among three children (Carla, who made it, but does not know how to play it; Bob, who has no other toy, but would like to have one; Anna, who is the only capable to play it). According to the Lockean theory, Carla "points out that she has been working diligently for many months to make the flute with her own labour (the others confirm this), and just when she had finished her work, 'just then', she complains 'these expropriators came along to try to grab the flute away from me'. If Carla's statement is all you had heard, you might be inclined to give the flute to her in recognition of her understandable claim to something she has made herself. Having heard all three and their different lines of reasoning, there is a difficult decision that you have to make. Theorists of different persuasions, such as utilitarians, economic egalitarians, or no-nonsense libertarians, may each take the view that there is a straightforward just resolution staring at us here, and there is no difficulty in spotting it. But almost certainly they would respectively see totally different resolutions as being obviously right. Bob, the poorest, would tend to get fairly straightforward support from the economics egalitarian if he is committed to reducing gaps in the economic means of people. On the other hand, Carla, the maker of the flute, would receive immediate sympathy from the libertarian. The utiliarian hedonist may face the hardest challenge, but he would certainly tend to give weight, more than the libertarian or the economic egalitarian, to the fact that Anne's pleasure is likely to be stronger because she is the only one who can play the flute (there is also the general dictum of 'waste not, want not'). Nevertheless, the utilitarian should also recongize that Bob's relative deprivation could make his incremental gain in happiness from getting the flute that much larger. Carla's 'right' to get what she has made may not resonate immediately with the utilitarian, but deeper utilitarian reflection would nevertheless tend to take some note of the requirements of work incentives in creating a society in which utility-generation is sustained and encouraged through letting people keep what they have produced with their own efforts. The libertarian's support for giving the flute to Carla will not be conditional in the way it is bound to be for the utilitarian on the working of incentive effects, since a libertarian would take direct note of a person's right to have what people have produced themselves. The idea of the right to the fruits of one's labour can unite right-wing libertarians and left-wing Marxists (no matter how uncomfortable each might be in the company of the other). The general point here is that it is not easy to brush aside as foundationless any of the claims based respectively on the pursuit of human fulfilment, or removal of poverty, or entitlement to enjoy the prodcuts of one's own labour. The different resolutions all have serious arguments in support of them, and we may not be able to identify, without some arbitrariness, any of the alternative arguments as being the one that must invariably prevail”. 
to achieve exclusivity ${ }^{106}$, with a further array of more or less tailored exceptions for any kind of IP right which also contributed - and still very much contributes - to a better and more refined equilibrium ${ }^{107}$. The rise of "intellectual capital-

106 As remarked by Gallini E Scotchmer, Intellectual Property: When Is It the Best Incentive (supra, note 38, p. 62), "if the sole concern is to avoid deadweight loss that occurs through proprietary prices, then IP should not exist at all. A finite length of protection balances these two concerns".

107 According to Füller, in Stoll, Busche \& Arend (Eds.), WTO - Trade-Related Aspects of Intellectual Property Rights (supra, note 28), p. 279, referring to WTO Panel in the "U.S.Section 110(5) Copyright Act" case, WT/DS160/R, exceptions do eliminate an already existing exclusive right, while limitations restrict such a right to a certain extent: moreover, this distinction would be purely theoretical, because both exceptions and limitations are subject to the three-steps-test under Art. 13 TRIPs. However, on one hand, Arts. 17 and 30 only provide restraints for exceptions and not for limitations; on the other, also in copyright, limitations ought to be severed by the more ontological "limits" of the institution itself, as well as the "free uses" were originally intended in the German doctrine. Also in EU Law, these "limits" might not be therefore subject to the TRIPs regime on (limitations or) exceptions especially if they are, on their turn, expressions of the main cornerstones of EU Law, such as competition or free circulation of goods (and services): accordingly, the freedom of the airplanes to fly over private lands must be deemed as an ontological limit of material property, not as a limitation or exception to exploit one own's real estate, thus needing to be neither a "special case" (as in the U.S. Supreme Court case United States v. Causby, 328 U.S. 256, 1946), nor a statutory limitation or exception (as in $\$ 905$, BGB: Begrenzung des Eigentums). The freedom of material proprietors to rent or lend their houses without the architect's consent - under Article 2.3 of EC Directive No 92/100 (infra, text and note 169) - is, e.g., an exception, a limitation or an ontological "limit" to the copyright(s)? And how much an eventual obligation requiring the architect's consent in such cases, would be more an incentive for IP rights in comparison with a disincentive for the free circulation of real properties? Should also the ontological limits to copyright or other IP rights be expressly granted by a statutory provision - such as the strictly private copying by hand or many other non-competing uses by the material owners - the intellectual property would enjoy more a width "ffrom the depths to the heaven") than land properties under Roman or Common Law. Again, would also public lending be deemed as a "normal exploitation of the work", is private lending-since any measures taken by way of derogation from the exclusive public lending right should comply in particular with Article 12 of the Treaty (Recital No 14 of EC Directive 2006/115, codifying EEC Directive No 92/100) - an exception, a limitation or a "limit"? Compare Geiger, Drafting the Appropriate and Balanced Scope of Copyright Protection in the European Union. What Language Can Contribute to the Dabate, in Gendreau (ed.), Language and Copyright, Bruylant (2009), pp. 59 et seq., with the very shareable attempt for further and more open limitations - anyway complying with the three-steps-test - laid down in Article 5.5 of the European Copyright Code (Project, April 2010), still available at http://213.247.35.100/ copyrigh/Wit tem_European_copyright_code_21\%20april\%202010.pdf: "any other use that is comparable to the uses enumerated in art. 5.1 to 5.4(1) is permitted provided that the corresponding requirements of the relevant limitation are met and the use does not conflict with the normal exploitation of the work and does not unreasonably prejudice the legitimate interests of the author or rightholder, taking account of the legitimate interests of third parties. This provision, however, "does not allow new limitations by blending the criteria of articles 5.1 to 5.3" and is therefore probably destined to have a quite limited scope in practice, notwithstandig its potential relevance from a theoretical perspective, lacking a more general "fair use" defense in EU Law: see the contribution by Piotrant, in this volume. 
ism”, since the second half of the last century, and the already globalized race of the main investors in such intangible assets have clearly led to continuous enhancements of IP rights according to the economic theory as well as in its legal translation by international or EC provisions, so tipping the scales towards the incentive for right holders as the main - if not the only - goal of intellectual property $^{108}$. It is remarkable how the grant or the enforcement of these exclusive rights is increasingly deemed as the best incentive not only for the right holders themselves, but also for consumers and society as a whole, so that the promotion of public welfare through dissemination and access seems nowadays to be "internalized in" and no longer "opposed to" the incentive paradigm, with no apparent need for a counterbalance (see e.g. Recital No 2 of EC Directive No 2004/48 of 29 April 2004 on the enforcement of IP rights, according to which "the protection of intellectual property should allow the inventor or creator to derive a legitimate profit from his/her invention or creation. It should also allow the widest possible dissemination of works, ideas and new know-how", while at the same time "it should not hamper freedom of expression, the free movement of information, or the protection of personal data” ${ }^{109}$. If the individualistic and even monopolistic reward for the investment is per se the most efficient way to promote innovation and its dissemination - as affirmed since the first doctrines on the highest efficiency of capitalistic systems $s^{110}$ - it appears consequential that any increase in IP protection should paradoxically correspond to higher levels of development and common welfare, while limitations or exceptions for the public interest, in this framework, can be discretionally and expressly granted by the State ${ }^{111}$, conversely as once happened for privileges: a famous dictum in U.S. Law, according to which all "the noblest of human productions - knowledge, truths, ascertained, conceptions and ideas - become, after voluntary

108 Granstrand, The Economics and Management (supra, note 21), pp. 321 et seq.

109 But see Recital No 9 of the Directive, affirming that disparities in the protection of IP rights "also lead to a weakening of the substantive law on intellectual property and to a fragmentation of the internal market in this field. This causes a loss of confidence in the internal market in business circles, with a consequent reduction in investment in innovation and creation" [emphasis added]: the Freudian slip, in this recital, clearly reveals how the incentive paradigm is based in favour of the busineses' interests to invest and make profit rather than in the public interest to disseminate or access innovation.

110 Compare the different approaches, in comparison to the prevailing market rules, proposed by the European Patent Organisation, EPO Scenarios for the Future (How might IP regimes evolve by 2025?), European Patent Office, Munich, 2007, pp. 10 et seq., opposing society, technology and geo-politcs as alternative dominant drivers rather than business. From the synallagmatic perspective supported above, however, the opposing interests of business and society should be fairly balanced without dominance or "internalization" of one in the other, while technology and geo-politics should not be considered as parties to the ideal contract, but rather as objects and/or goals contained in it.

111 This is particularly evident in copyright: see Art.5(2) or (3) of EC Directive No 29/2001, making merely optional for the Member States - who "may provide" for - all the most important and traditional exceptions or limitations. 
communication to others, free as the air to common use"112, appears to be completely overruled to a great extent also in the European Law. This trend also seems to have been "constitutionalised" in Article 17.2 of the EU Charter of Fundamental Rights ${ }^{113}$, simply providing that intellectual property "shall be protected" without all limitations and exceptions in the public or general interest - e.g. in relation to dissemination or access - that, on the contrary, are explicitly mentioned in Article 17.1 for "material" property, as well as in many other Member States' constitutions since the seminal Weimarer Verfassung ${ }^{114}$ : once again the "incentive paradigm" might be found behind these new provisions and it appears quite useless - if not ingenuous - to explain them as a mere revival of natural law theories ${ }^{115}$. The full internalization of the «dissemination $\&$ access»

112 According to Justice Brandeis's famous opinion in the U.S. Supreme Court's case INS v. AP, 248 U.S. 215 (1918). Today this perspective appears to also be shared by the Catholic Church: see the intervention by Mons. D. Martin to the Plenary Council of the WTO on the Trade-related Aspects of Intellectual Property Rights, June 20, 2001 (available at http:// www.vatican.va/roman_curia/secretariat_state/documents/rc_seg-st_doc_20010620_wto_ en.html): "within a open free trade system, intellectual property rights constitute an exceptional monopoly regime. As an exception within a legal regime, its use must be narrowly interpreted and must take due account of and, where necessary be subordinated to, other important principles.

${ }^{113}$ For a more specific analysis, see the contribution by Geiger in this volume.

114 Also Art. 158 of the Weimar Constitution seemed to protect intellectual creations as such - by stating that "the rights of authors, inventors and artists enjoy protection and care of the Reich" - while limitations in the public interest were expressly laid down in Art. 153 only for traditional property. However, the general principle that all economic rights could also be limited "in the service of superseding demands of public welfare" was held in the basic Art.151, so linking the Eigentumsgarantie with the more general public interest: under Article 17.2 too, therefore, the fundamental EU rights "do not guarantee property rights in an abstract and absolute manner; instead, the right to property is defined and limited by its social purpose. The public interest, as well as the interests of those who have to respect the intellectual property of others, needs to be balanced against the proprietors' interest in protection (see Art. 1, $1^{\text {st }}$ additional protocol to ECHR, Art. 17(1) of the Charter). For instance, in terms of German constitutional law, it is prohibited to focus exclusively on the interests of beneficiaries when promulgating the rules for protection of property guaranteed under the Constitution. Finally, unlimited protection for intellectual property would also clash with the obligations following from the TRIPS Agreement that are also binding on the Community. The preamble should therefore make reference to the necessity of respect being paid to public interests as well as to conflicting fundamental rights", as correctly remarked by Hilty, Kur E Peukert, Statement of the Max Planck Institute for Intellectual Property, Competition and Tax Law on the Proposal for a Directive of the European Parliament and of the Council on Criminal Measures Aimed at Ensuring the Enforcement of Intellectual Property Rights (2006), $\$ 9$.

115 According to historical doctrines on recurring cycles in law and jurisprudence, since Vico, The New Science (1999, following Vico's $3^{\text {rd }}$ edition, 1744], 400 et seq.; for the debate between Diderot and Condorcet - according to their opposite view on natural or statutory rights for patents and works-of-mind - see Hilaire-Perez, Diderot's Views on Artists' and Inventors' Rights: Invention, Imitation and Reputation, (2002) 35 British Journal for the History of Science 129 et seq. 
rationale inside the (once opposing) "incentive paradigm", reveals how much the proprietary theories - according to which, self-interest is the most efficient tool for promoting the public and general interest ${ }^{116}$ - have already, although roughly, been translated into EU statutory and constitutional principles. Is this point significant enough to reverse the original liberties provided for in the EC Treaty, under which the free movement of goods or services still seems to be the rule, while the protection of the IP rights remains construed as a derogation (compare EC Treaty, Articles 23 and 39 et seq. with Article 30$)^{117}$ ? On this point it is remarkable how the whole EU harmonization of intellectual property among Member States has been achieved in the name of the principle of the free circulation of goods in the internal market, but only for the purpose of raising such an approximation to the highest level of protection: also in the technological domain, thus, instead of assuring a competitive "race of patents" which balances the incentive to innovation for both incumbents and new-comers - as is assumed by many economic models ${ }^{118}$ - the EU harmonization has developed a "race to the top" in terms of substantive or procedural levels of protection, in a one-way direction which mainly fosters the former without favouring correspondent dissemination or access facilities ${ }^{119}$. See e.g. Recital No 7 of EC Direc-

116 Smith, An Inquiry into the Nature and Causes of the Wealth of Nations (1977 [1776]) bk. IV, ch. 2: "by pursuing his own interest", every individual "frequently promotes that of the society more effectually than when he intends to promote it". That private property alone offers a system in which idleness is not rewarded at the expense of industry or welfare -i.e. a system in which those who take on the burdens of prudence and productivity can expect to reap some reward for their virtue, which distinguishes them from those who did not make any such effort - is re-affirmed also nowadays: compare generally Munzer, A Theory of Property (1990), pp. 285 et seq., with Nozick, Anarchy, State and Utopia (1974), pp. 158 et seq. (perhaps more sensitive to some distributive task of property rights, in a market economy, at least at the time of their initial allocation).

117 Eawniczak, in Lidgard \& Atik (eds.), The Intersection of IPR and Competition (supra, note 32), pp. 63 et seq.

118 See Denicolò, Patent races and optimal breadth and length, in 44 Journal of Industrial Economics 249 et seq. (1996), confirming that property rights in patents are not incentives as such for licensing, which depends on many different market factors. On the above mentioned "race to the top" in favour of the right holders' incentives only - compared with a "race to the bottom" when the users' interest should be protected - see Ricolfi, in Cottino (ed.), Trattato di Diritto Commerciale (2001), p. 453, text and footnote n.175.

119 On the contrary, a veritable "race to the bottom" takes place when the free circulation of goods is invoked by some firm in order to dilute a well established standard or quality of a product (as in the area of foodstuff, if not so specific to be protected as a geographical indication): among the latest, see e.g. ECJ, 25 November 2010, C-47/09, Pure Chocolate, affirming that it is apparent from prior case-law "that the use of vegetable fats other than cocoa butter, within the limits set by Article 2(1) of Directive 2000/36, does not per se bring about sufficient alteration of those products to justify a difference in their sales names (...). Therefore, even though, according to the Italian legislation, the use of the adjective 'pure' is not compulsory, authorisation to introduce sales names that are different from those provided for by Directive 2000/36 would suggest the existence of a difference between the essential characteristics of the products concerned": as a consequence - according to the judgment - by providing that 
tive No 98/44 (an "uncoordinated development of national laws on the legal protection of biotechnological inventions in the Community could lead to further disincentives to trade, to the detriment of the industrial development of such inventions and of the smooth operation of the internal market"); Recitals Nos 5, first part, and 14 of Regulation No 2100/94 ("in order to stimulate the breeding and development of new varieties, there should be improved protection compared with the present situation for all plant breeders" and consequently "the scope of protection should be extended, compared with most national systems, to certain material of the variety to take account of trade via countries outside the Community without protection") ${ }^{120}$; Recitals Nos 2 and 8 of EEC Regulation No $1768 / 92^{121}$ of June 18,1992 , on the creation of supplementary protection certificates ("medicinal products, especially those that are the result of long, costly research will not continue to be developed in the Community and in Europe unless they are covered by favourable rules that provide for sufficient protection to encourage such research", so that "the duration of the protection granted by the certificate should be such as to provide adequate effective protection"); Recitals Nos 3 and 11 of EEC Regulation No 1610/96 of July 23, 1996 (same wording for the creation of a supplementary protection certificate for plant protection products). Furthermore, the last Regulation offers another example of the abovementioned "internalization" of once exogenous and counterbalancing factors - such as the common welfare or the public interest - inside the "private incentive" itself: see e.g. Recital No 8, according to which, the EC Council and Commission have "stressed the interdependence of economic growth and environmental quality", so that an "improving protection of the environment means maintaining the economic competitiveness of industry"; as a syllogistic conse-

the adjective 'pure' may be added to the sales name of chocolate products which do not contain vegetable fats other than cocoa butter, the Italian Republic has failed to fulfil its obligations under Article 3(5) of Directive No 2000/36/EC of 23 June 2000, relating to cocoa and chocolate products intended for human consumption, and under Article 3(1) of that directive, read in conjunction with Article 2(1)(a) of Directive No 2000/13/EC of 20 March 2000, on the approximation of the laws of the Member States relating to the labelling, presentation and advertising of foodstuffs. On prior case law in the same sense - in respect of the quality of the German beer or the Italian pasta - see respectively ECJ, 12 March 1987, C-178/84, and ECJ, 14 July 1988, C-90/86.

120 For more tailored-made regulations in Europe, not totally depending on the United States' impositions under the UPOV Agreement, Bruguière, Mondialisation et droit des obtentions végétales, in Vivant (ed.), Propriété intellectuelle (supra, note 39), pp. 153 et seq.

121 Concerning the creation of supplementary protection certificates in medicinal products. More recently, see furthermore Recitals Nos 3 and 6 of EC Regulation No 469/09, 6 May 2009 - which codify the updated version of Regulation No 1768/92 - concerning the supplementary protection certificate for medicinal products: "medicinal products, especially those that are the result of long, costly research will not continue to be developed in the Community and in Europe unless they are covered by favourable rules that provide for sufficient protection to encourage such research", at the "risk of research centres situated in the Member States relocating to countries that offer greater protection"). 
quence of these premises, accordingly, "the issue of a supplementary protection certificate can be regarded as a positive measure in favour of environmental protection". Only for this specific subject-matter - particularly relevant for healthcare - there was the special need for a fair balance with more (exogenous) general public interests (such as competitors, rather than users), expressly mentioned in the latter regulations: see e.g. Recitals Nos 9 and 10 of EEC Regulation No 1768/92 ("all the interests at stake, including those of public health, in a sector as complex and sensitive as the pharmaceutical sector must nevertheless be taken into account" and "a fair balance should also be struck with regard to the determination of the transitional arrangements”). The same premises in Recitals Nos 12 and 15 of EC Regulation No 1610/96 have also led to a more strictly limited duration of certificates both for plants and medicinal products - which cannot be granted for a period exceeding five years, unlike some prior national rules mentioned ${ }^{122}$ - while, in pharmaceutical sectors, the protection "should furthermore be strictly confined to the product which obtained authorization to be placed on the market as a medicinal product" (Article 13.2 of EEC Regulation No 1768/92): these statements, as explained above, contribute to confirm the deep links between incentives in EU Law and the higher level of legal protection granted through exclusive rights, while all limitations or exceptions to such exclusivity - such as the boundaries of scope, extent or duration - involve an exogenous and opposite "access or dissemination paradigm" that is actually impossible to internalise in the individual "incentive paradigm" (as if, in a contract of sale, some law could heavily increase the seller's rights only, assuming to "internalise" in this way the opposite rights of the buyer and to represent more efficiently the latter's interests too). Vice-versa, the need for a fair balance between the economic rewards for creative innovation and the incentives to disseminate the proprietors' works or inventions - so permitting an equitable access by interested and worthy third parties, from users to competitors - also seems to benefit the right holders themselves: it is self-evident that, as a matter of fact, the effects of too strong incentives, like unselective subsidies, can not be subject to further governance, as happens in the case of traffic jams which might occur when too many people are incentivised to buy or use cars; in addition, too stringent efforts in enforcing right holders' interests may lead to efficient results in the short to medium term for them and perhaps for the common welfare, but, in the medium to long run, an almost inextricable overproduction of output - again, like a traffic jam - may arise aside from the increasing shortage of input, as happens when fish becomes scarce after too much trawling ${ }^{123}$. The so called "public goods" (in their eco-

122 The purpose of "preventing the heterogeneous development of national laws leading to further disparities which would be likely to hinder the free movement of plant protection products within the Community and thus directly affect the functioning of the internal market" was explicit in Recital No 9 of Regulation No 1610/96.

${ }^{123}$ According to Campbell, Incentives (supra, note 49), p. 556, "suppose that each of $n$ 
nomic meaning $)^{124}$, like innovative ideas or works of authorship, are not unlimited - as is too often superficially believed - and granting increasingly higher protection to increasingly lower output can cause a "rights jam" which ends up blocking instead of speeding up creative innovation: in this sense, the "tragedy" of commons might soon turn into a veritable disaster ${ }^{125}$, as is rightfully affirmed against the optimism of the neo-Schumpeterian theories, not only for third parties, but also for "true" creative inventors, increasingly threatened by patent trolls' ambushes from behind ${ }^{126}$ rather than by infringers' frontal attacks.

\section{Back to the basic principles: the grounds for (re)balancing IP rights as competitive incentives and not entrepreneurial attempts to monopolize}

While patent trolls' suits show another significant example of how much the incentive paradigm has turned IP rights into a static incentive for a merely financial gain - in comparison to its original and celebrated justification as allowing for the dissemination of knowledge in the best way, when profit and rewards were only tools, not the main goal, of granting patents ${ }^{127}$ - the increasingly extensive patent pools try to solve the problem of a "rights-jam", due to so many patents being granted even for more trivial inventions: the remedy, however, risks being worse than the disease. On one hand, indeed, these agreements act downstream, when the crowd of patents has already been issued, and not at the root of the question (where a more selective grant of "worthy" patents, es-

firms has free access to a resource from which it can extract a marketable commodity, say fish. If we assume that the amount harvested by any entrepreneur depends on the efforts expended by that agent and also on the efforts of all others, and if we assume in addition that output per unit of effort declines as the total effort of fishers increase, then we have the classical common property resource model in which the pursuit of self-interest leads to an inefficient rate of extraction in the short run and insufficient conservation in the long run". However, especially in intangible assets, the risk of under-exploitation turns into its opposite, giving rise to the (dark) "comedy of commons", as demonstrated by C. M. Rose, The Comedy of the Commons: Commerce, Custom and Inherently Public Property, 53 U. Chicago L. Rev. 711 et seq. (1986), also for land properties in regard of environment.

124 Following P. A. Samuelson, The Pure Theory of Public Expenditure, 36 Rev. Econ. \& Stat. (1954), 387 et seq.

125 Compare Vanneste, Parisi, Vanhiel E Depoorter, From 'Tragedy' to 'Disaster': Welfare Effects of Commons and Anticommons Dilemmas, in 26 International Review of Law and Economics (2006), pp. 104 et seq., with Buchanan \& Yoon, Symmetric Tragedies: Commons and Anticommons, 43 Journal of Law and Economics (2000), pp. 1 et seq.

${ }_{126} \mathrm{Ng}$ E Siew: Patent Trolling: Innovation at Risk, [2009] EIPR 593 et seq.; compare also Subramanian, Patent Trolls in Thickets: Who is Fishing Under the Bridge? [2008] EIPR 182 et seq., with Golden, 'Patent Trolls' and Patent Remedies, 85 Tex. L. Rev. 2111 et seq. (2007).

${ }_{127}$ MacMillan, Copyright and corporate power (supra, note 10), pp. 111 et seq. 
pecially in relation to their inventive step and specific industrial application, should be taken into account, hopefully avoiding the above criticised "blanket-incentive" paradigm or the "free hunting" theories in favour of the incumbent right holders only) ${ }^{128}$; on the other hand, because these collective packs of patents and other connected IP rights can give rise to barriers towards users or new-comers which are much higher than the benefits of this one-shop-system model for the dissemination of the interconnected technologies, considering, in particular, that the incentive to dissemination should be the main social goal of the patent system as such and not a benevolent "favour" by the pooling parties $^{129}$, eventually enacted after an injunctive order to license by the antitrust authorities. The solutions adopted both in Europe and the USA, especially in case law, seek more to cure the symptoms - case by case or through extemporary measures - than the illness ${ }^{130}$, while structural antibodies are probably needed to counterbalance today's absolute incentive to monopolize almost all innovative inputs with no equal counter-incentive to disseminate them ${ }^{131}$ : it remains, however, a true challenge to look for common principles in order to vaccinate EU patents and other IP rights against just the private incentive, but this challenge is not insurmountable and may even stimulate in an analysis of the very core of the EU legal system against the risks of insulation of the intellectual property from the balance of other individual and social rights, including the public interest in the domain publique both for free or equitable payment (as happens for compulsory licenses or "voluntary public licenses", promoted with tax incentives, but still confined to Article 43 of the Community Patent Agreement, which could nonetheless form a basic pattern for shaping future EU Law to have more open principles on patent law too ${ }^{132}$. This more general

128 "Ideally, a patent right (and the market power it might create) should be granted only if, and only to the extent that, it is necessary to encourage the innovation covered by the right": OECD, Competition, Patents and Innovation (supra, note 47), p. 21. Of course, a stricter selection should be based upon the objective requirement of (a higher level of) inventive step, not on discretional grounds of public choice as the privilèges octroyés did. Further conditions - such as the effective worth, usefulness, efficiency or the economic chance of exploitation - should not be taken into account per se when granting patents, as the EPO guidelines stress, because even the most innovative invention may be more expensive or too "early" for the standing market.

129 Carlson, Patent Pools and the Antitrust Dilemma, in Yale Journal on Regulation 1999, pp. 359 et seq.

130 Compare Van Overwalle (ed.), Gene Patents and Collaborative Licensing Models: Patent pools, Clearinghouses, Open Source Models and Liability Regimes (2009), with Magliocca, Blackberries and Barnyards. Patent Trolls and the Perils of Innovation, 82 Notre Dame L. Rev.1809 et seq (2007).

131 As more traditionally provided for patents only, but nowadays necessary for all IP rights: see Ghidini, Innovation, Competition and Consumer Welfare (supra, note 27), pp. 33 et seq.

132 Where the proprietor of a Community patent files a written statement with the European Patent Office that he is prepared to allow any person to use the invention as a licensee in 
point of view - restoring the links between property rights and competition or free circulation of goods, services, etc. - is perhaps suitable to show a further perspective acknowledging the underlying principles for counterbalancing the otherwise absolute incentive paradigm: if the patentee's exclusivity is not a natural, unilateral or absolute right, but an entitlement granted in consideration of a social contract, as the historical evidence demonstrates ${ }^{133}$, a deeper analysis makes it possible to apply many of the economic models for contractual relations on opportunistic behaviours, moral hazards, and so on, to the societypatentee agreement as a principal-agent relationship ${ }^{134}$. According to this per-

return for appropriate compensation, the renewal fees for the Community patent which fall due after receipt of the statement shall be reduced (the amount of such a reduction shall be fixed in the rules relating to fees): on the basis of the statement, any person shall be entitled to use the invention as a licensee under the conditions provided in the implementing regulations. A licence so obtained shall be treated as a contractual licence and an EPO Revocation Division shall determine the appropriate compensation or shall review it, if circumstances have arisen or become known, which render the compensation determined obviously inappropriate. This voluntary kind of public license has been deemed a statutory incentive to disseminate in EU patent law, but in fact it is too poor to work effectively on mere voluntary grounds, due to the very limited savings gained on the reduction of renewal fees in comparison to a more extensive regime of domaine publique payant: for this criticism, see e.g. Vanzetti $\& D i$ Cataldo, Manuale di diritto industriale (2009), p. 466, with reference to the similar provision laid down in Art. 80 of the Italian Code of Industrial Property. Moreover, if there is a complete change of proprietorship of the patent as a result of legal proceedings, the statement for the public licence is deemed to be withdrawn upon the entry of the name of the person entitled to the patent in the Register of Community Patents: see the last sentence of Art. 43(1), Community Patent Convention.

133 On the original theory of the contrat social for the acknowledgment of property rights, see Bertram, Rousseau and the Social Contract, Routledge (2003), pp. 72 et seq.; on the legal grounds for patents as contracts between Society and inventors, granting protection in return for disclosure and society's cultural and technological development - since T. Jefferson's clear statements - see David, Intellectual Property Institutions: Patents, Copyrights, and Trade Secrets in Economic Theory and History, in The National Reserarch Council, Global dimensions of intellectual property rights in science and Technology (1993), pp. 19 et seq., at 26. On the contrary, the theory of IP rights as natural rights is more simplistic, having only to be asserted and not demonstrated or evalued by the courts, case by case, in order to maintain fairly balanced: Guellec, Patents as an Incentive to Innovate, in Guellec \& van Pottelsberghe de la Potterie (eds.), The Economics of the European Patent System (supra, note 95), p. 54, stressing how this theory is nevertheless adopted without further analysis by the courts, at times of expanding and strengthening of IP rights as is the case nowadays.

134 See supra, text and note 102. Also Kant's seminal perspectives about the grounds of property emphasized "a general connection between property and agency, maintaining that there would be an affront to agency and thus to human personality, if some system were not arrived at which could permit useful objects to be used" (Stanford Encyclopedia on Philosophy, entry "Property", at http://plato.stanford.edu/entries/property/). Notwithstanding his view of "copyright" in particular as a "personal" right - then shifted to a "Geistiges Eigentum" under German and French doctrines "la plus personnelle de toutes le propriétés", according to the well-known foreword to the French Copyright Decree of 1793 by Le Chapelier) - he also concluded on "material" property that "it is, however, evident that a man entirely alone upon the earth could properly neither have nor acquire any external thing as his 
spective, the incentive paradigm should no longer be insulated alone and counterbalanced only by economic concerns related to deadweight losses, but rather it should also be balanced by further obligations of fairness and good faith in return to the other party - i.e. to the public interest - so that, through this balancing, the above mentioned models should be translated into the framework of the EU legal system too ${ }^{135}$ : without an "ethical" obligation of fairness and good faith for the patentee as well, which can settle further duties or unwritten limitations too, the agreement between him/her and the State/Society would be significantly undermined - as it would be in case of private bargaining ${ }^{136}$ - until the possible breach of this synallagmatic relationship and the following termination for default. Revocation, forfeiture and other sanctions for patent or other IP rights misuse, should be read in the context of this contractual framework (quid pro quo): this argument must therefore be stressed in opposition to the progressive lowering of these sanctions (which might well be criticised) in the last decades to the point that they are practically nullified - see e.g. Article $5 \mathrm{~A}$ of the Paris Convention on patented inventions which fail to work or which work insufficiently ${ }^{137}$ - in a way which is inversely proportional to the increasing influence of the «incentive paradigm» only.

own; because between him as a Person and all external Things as material objects, there could be no relations of Obligation. There is therefore, literally, no direct Right in a Thing, but only that Right is to be properly called 'real' which belongs to any one as constituted against a Person, who is in common possession of things with all others in the Civil state of Society": Kant, The Philosophy of Law. An Exposition of the Fundamental Principles of Jurisprudence as the Science of Right, transl. by Hastie, (1887 [1796]), Science of Right, Part I, Chapter II, $1^{\text {st }}$ sec., $\ 11$. These conclusions would be even more in compliance with ideas or other immaterial "speeches", according to Kant's theory on the unlawfulness of printing books without the author's consent). See Verhaegh, Kant and Property Rights, in Journal of Libertarian Studies, 2004, pp. 11 et seq.; Gregor, Kant's Theory of Property, in Review of Metaphisics (1988), pp. 757 et seq.

135 Returning to the seminal and famous teaching of the Weimar Constitution that "property obliges" and "its use shall simultaneously be service for the common best" (Art. 153, last par.). In relation to the U.S. legal system, see Beviglia Zampetti, Fairness in the world economy: US perspectives on international trade relations (2006), pp. 181 et seq.

136 A statutory obligation of Treu und Glamben for the patentees as such - independent from antitrust provisions - might be deduced, also in Europe, from Art. 5(A)2 of the Paris Convention for the protection of industrial property: "each Country of the Union shall have the right to take legislative measures providing for the grant of compulsory licenses to prevent the abuses which might result from the exercise of the exclusive rights conferred by the patent, for example, failure to work".

${ }_{137}$ As revised in The Hague (6 November 1925). The prior texts provided for direct forfeiture in the case of a failure to work: see Eikermann, in Stoll, Busche \& Arend (eds.), WTO - Trade-Related Aspects of Intellectual Property Rights (supra, note 28), p. 558 et seq., with further references, remarking that compulsory licenses were not permitted at all in the first U.S. proposal. In the framework of this perspective of the grounds for IP rights' as the consideration (quid pro quo) of a "social contract" and not as all-inclusive natural rights, it is notable that the "payment" to Society, in exchange for the grant, was not only the disclosure - as is often uniquely affirmed nowadays - but also the work of the invention. According to the 


\section{The grounds for copyright protection: still an incentive to create and disseminate the authors' cultural creations or an absolute shield to protect the entertainment industries' goodwill?}

A "race to the top" is even more evident in the EU approximation of copyright law: see Recital No 4 of EC Directive No 2001/29 (“a harmonised legal framework on copyright and related rights, through increased legal certainty and while providing for a high level of protection of intellectual property, will foster substantial investment in creativity and innovation, including network infrastructure, and lead in turn to grow th and increased competitiveness of European industry, both in the area of content provision and information technology and more generally across a wide range of industrial and cultural sectors: this will safeguard employment and encourage new job creation”), but it can also be found in the EU trade mark law, which has been "harmonized" towards the top levels of protection existing only in a few Member States at the time, i.e. the Benelux legal system: see e.g. Recital Numbers 2 and 9 of the EEC Directive No 89/104 ${ }^{138}$, of 21 December1988 ("it is important not to disregard the solutions and advantages which the Community trade mark system may afford to undertakings wishing to acquire trade marks to approximate the laws of the Member States relating to trade marks", so that it becomes "fundamental, in order to facilitate the free circulation of goods and services, to ensure that henceforth registered trade marks enjoy the same protection under the legal systems of all the Member States". Moreover, this approximation to higher common standards should not prevent Member States, at their option, from granting more extensive protection to those "trade marks which have a reputation"). The same rationale supports the harmonisation to the highest range of protection in the case of Member States' laws governing designs and models (see Recital No 4 of EC Directive No 98/71, 13 October 1998), furthermore, extended to a very criticisable accumulation of measures including all the copyright protective measures regardless of any difference in the more selective requirements, that are eventually left to the option of individual Member States only as to the

\footnotetext{
Statute of Monopolies (Sec. 6), "the patentee's consideration for the grant was that he would put the invention to use" (Adams, History of the Patent System, in Takenaka, Patent Law and Theory (supra, note 43), p. 103): the international abrogation of such performance, in return for wider and wider exclusivities, therefore, totally unbalances the original scales, since the failure of the invention to work is possibly sanctioned only if abusive and after the (eventual) application for a compulsory license, no longer for failure to perform as such.

${ }^{138} \mathrm{Kur}$, Fundamental Concerns in the Harmonization of (European) Trademark Law, in Dinwoodie \& Janis (eds.), Trademark Law and Theory. A Handbook of Contemporary Research (2008), pp. 151 et seq.
} 
quantum, and not as to the an itself ${ }^{139}$. Once again, the incentive rationale seems to be turned into an irrational cumulation of incentives through differentlyshaped exclusive rights, which were originally and still are designed for distinct subject-matters. Such an "amassing” of incentives in a range of exclusive rights - including bans on slavish imitation, look-a-likes, etc. ${ }^{140}$, with all the more or less extended arrays of provisions against unfair competition - not only raises the problem of a "rights-jam" over the top (creating a correspondent amassing of property rights), but also takes no care to install traffic lights to solve the unavoidable questions about their reciprocal compatibility ${ }^{141}$ : what if a design right

139 Italian Public Law No. 273 of December 12, 2002, purported to set the duration of copyright in designs at the life of the author plus 25 years, that is, consistently with the Berne Convention: the European Commission found, however, that this statutory law did not comply with EEC Directive No 93/98, which provides for a general term for all works, normally life plus 70 years, without excluding industrial designs. In order to avoid an official sanction, the transitional provision in Art. 239 of the Code of Industrial Property was then amended to provide that copyright protection accorded to industrial designs applies to these works for exactly the same terms as apply to other works generally. See the Italian Governmental Decree No.10, of Feb. 15, 2007, immediately effective, as ratified by Public Law No. 46, April 6, 2007, in the Italian Official Journal, April 11, 2007, No. 84, and further Art. 19(6) of Public Law No. 99 of July 23, 2009, in the Italian Official Journal, July 31, 2009, No. 176, Suppl. No. 136, effective Sept. 15, 2009: on the protection of the reliance interests by third parties, see also Musso, entry "Italy", in Geller (ed.), (supra, note 5), $\$ 3[2][c]$, p. 33 et seq.

${ }^{140}$ See e.g. the "continued application of [all the] other legal provisions", under Art. 13 of the EC Directive No 9/96 on design rights ("this Directive shall be without prejudice to provisions concerning in particular copyright, rights related to copyright or any other rights or obligations subsisting in the data, works or other materials incorporated into a database, patent rights, trade marks, design rights, the protection of national treasures, laws on restrictive practices and unfair competition, trade secrets, security, confidentiality, data protection and privacy, access to public documents, and the law of contract"), repeated in Art. 9 of EC Directive No 29/2001 on copyright; or the "relationship to other forms of protection", under Art. 16 of EC Directive No 98/71 ("the provisions of this Directive shall be without prejudice to any provisions of Community law or of the law of the Member State concerned relating to unregistered design rights, trade marks or other distinctive signs, patents and utility models, typefaces, civil liability or unfair competition"). Compare Obly, The Freedom of Imitation and its limits: A European Perspective (2010) 41 IIC, pp. 506 et seq., with Kamperman Sanders, Do whiffs of misappropriation and standards for slavish imitation weaken the foundations of IP law?, in Derclaye (ed.), Research Handbook on the Future of EU Copyright (2009), pp. 567 et seq.

${ }^{141}$ See also the cumulative protection, through design registration and patent for utility model, provided by Art. 40 of the Italian "Industrial Property Code", when an industrial device has both aesthetic and technical features, that, however, does not solve the question of what remains protected under the design right after the expiration of the utility model (or vice versa). In case of such an "amassing" of IP rights, involving different protections for the same feature, a functional approach in EU Law should lead to each protection's proper scope only: see e.g. Ghidini, Intellectual Property and Competition Law. The Innovation Nexus (2006), pp. 126 et seq., arguing that - after the patent has expired - the model already protected by design rights should be considered to be in the public domain, but only for the aesthetic aspect of the industrial product. Accordingly, after the expiration of design rights, a (possible) ongoing protection under copyright law should include sculptures or other art works, but no longer 
expires or is transferred, while the copyright is still pending or has not been assigned or licensed to the same transferee? Put more simply, why should a design or model be registered - involving registration fees, examination, disclosure, and all the other duties in return for exclusivity, according to the "incentive/ access" contractual paradigm of patents ${ }^{142}$ - when a stronger and longer lasting copyright protection is directly available without publication, formalities, costs, etc.? While the invention-for-hire doctrine has been developed to let employers collect their employees' patent rights both to foster the employers' investment and to centralise their control on the exploitation or the assignment of the invention, EU copyright harmonization - for its part - has added more and more "proprietors" to intellectual creations. Such a proliferation of right holders' in copyright, neighbouring or sui generis rights, multiplies entitlements in order to grant incentives to all kinds of cultural industries ${ }^{143}$, substantially splitting the same cake among a plethora of proprietors and property rights, but - in doing so - contradicting the doctrine of property rights as an incentive for dissemination or more innovative works ${ }^{144}$ : an overly complex and almost unmanageable mechanism of collective authorisation or fair compensation via many collecting societies or private agencies ${ }^{145}$ tries to avoid the substantial failure of this

uses applied to mere industrial products. For some attempts to solve these inextricable problems, Quaedvlieg, Overlap/Relationships between Copyright and other IP rights, in Derclaye (ed.), Research Handbook on the Future (supra, note 140), pp. 480 et seq.

142 Unlike many prior national laws in the Member States, under Art. 7.1 of the EC Directive No 98/71, a design right shall not subsist in features of the appearance of a product which are "solely dictated by its technical function", thus granting these longer rights also to features with a $99 \%$ technical function and only a $1 \%$ applied "aesthetic" function. The same question arises with computer interfaces: as the European Court of Justice has ambiguously affirmed, "where the expression of those components is dictated by their technical function, the criterion of originality is not met, since the different methods of implementing an idea are so limited that the idea and the expression become indissociable (...). Nevertheless, such an interface can be protected by copyright as a work by Directive No 2001/29 if that interface is its author's own intellectual creation” (ECJ, 22 December 2010, C-393/09, Bezpečnostní softwarová asociace v. Svaz softwarové ochranypara, still unpublished, at para. 49 and 51).

143 Also known as the théorie du gateau (Durante, I diritti dei musicisti interpreti (2000), pp. 31 et seq.). On the rationale for the invention-for-hire doctrine, Chandler: Ownership of Employees' Inventions. Duties, Expectations and Variable Objectivity [2008] EIPR 164 et seq.

144 See Obly, Urheberrecht zwischen Innovationsstimulierung und -verhinderung, in Hoffmann-Riem \& Eifert (eds.), Geistiges Eigentum und Innovation (2008), pp. 279 et seq.; van Eechoud, Hugenholtz, Guibault, van Gompel \& Helberger, Harmonizing European Copyright Law. The Challenges of Better Lawmaking (2009). Compare the seminal criticism on Kulturindustrie for its main role of rent-seeking "gatekeepers" in respect of the free dissemination of the works of authorship and of the users' choices, through a veritable mass deception (Massenbetrug), by Horkheimer E Adorno: Dialektik der Aufklärung (1944), with the more recent analysis - from a legal and economic perspective - by Caves: Creative Industries. Contracts between Art and Commerce, 2000, pp. 52 et seq.

145 See Kretschmer, Copyright Societies do not Administer Individual Property Rights: the Incoherence of Institutional Traditions in Germany and the UK, in Towse (ed.), Copy- 
crowd of suitors' earning expectations, but the EU system is far from perfect, and appears to be more suited to reward major associations or "a happy few" than to managing fair use for competitors or users ${ }^{146}$. As a matter of fact, lack-

right in the cultural industries (supra, note 8), pp. 140 et seq.; in particular, while also "with regard to the making available in on-demand services by broadcasters of their radio or television productions incorporating music from commercial phonograms as an integral part thereof, collective licensing arrangements are to be encouraged in order to facilitate the clearance of the rights concerned" (Recital No 26 of EC Directive No 2001/29), all copyrights, included rental and public lending rights, are still construed as individual rights. Thus, while Art. 4 of EEC Directive No 92/100 states that the administration of rights to obtain an equitable remuneration may be entrusted to collecting societies representing authors or performers, and that Member States may regulate whether, and to what extent, administration by collecting societies of the right to obtain equitable remuneration may be imposed, as well as the question from whom this remuneration may be claimed or collected, there is no mandatory obligation to administer such individual rights through collecting societies (an extended mandatory administration is only provided for cable retransmissions under Art. 9 of the EEC Directive No 93/83, of 27 September 1993, on the coordination of certain rules concerning copyright and rights related to copyright applicable to satellite broadcasting and cable retransmission). Finally, Art. 4 of the EC Directive 2006/115 addresses collective management as a model for the management of equitable remuneration rights, but does not in any way make collective management a requirement: therefore, in practice, even if all rental shops or libraries have signed an agreement with the right holders' collective societies, would this agreement be binding on right holders who are not members of the societies? Is every renter or librarian obliged to check that all the right holders of each book, dvd, etc., going to be rented or lent in the shop or the library, have agreed to rental or lending by collective agreement? If not, may the right holder, who is not a member of collective bargaining societies, sue the shop or the library for infringement individually, claiming for all the civil and criminal sanctions? The same questions arise for the resale right, because the Member States "may provide" for compulsory or optional collective management of royalties (Art. 6.2 of the EC Directive No 2001/84 the resale right for the benefit of the author of an original work of art): even here, however, the problem of non-member right holders is left totally unsolved. These questions still remain to be answered, because - despite the proclamation of individual rights of availability to public, rental, lending, etc. - only bargaining by the majors' collective entities seem to be taken into account by EU copyright practice: see e.g. Ficsor, Collective Management of the Copyright in the Digital, Networked Environment: Voluntary, Presumption-Based, Extended, Mandatory, Possible, Inevitable? in Gervais (ed.), Collective Management of Copyright and Related Rights, (2006), pp. 37 et seq.

${ }_{146}$ Compare the inquiry by Rochelandet, Are Copyright Collecting Societies Efficient Organisations? An Evaluation of Collective Administration of Copyright in Europe, in Gordon \& Wyatt (eds.), The Economics of Copyright (supra, note 32), pp. 181 et seq., with the attempt to share equitable remuneration by many collecting societies among both stars and new entries, which is, however, obstructed by the lack of an extended license: therefore, a "happy few" authors or right holders may not be members and do not share such a cooperative goal, retaining their individual rights to negotiate: see Frabboni, From copyright collectives to exclusive clubs: the changing faces of music rights administration in Europe, (2008) Entertainment Law Review, 100 et seq.; Snow $\mathcal{E}$ Watt, Risk sharing and the distribution of copyright collective income, in Takeyama, Gordon \& Towse (eds.), Developments in the Economics of Copyright (2005), pp. 23 et seq.; also compare, ECJ, 21 October 2010, C-467/08, Padawan, reaffirming the sole "incentive paradigm" by declaring that the fair remuneration for private copying must be only regarded as recompense for the harm suffered by the author 
ing the authorisation of one or some of the right holders - e.g. for opportunistic behaviour, due to an absence of reliable information on coheirs, assignees, etc. - a copyrighted work has much fewer chances than a patent to be licensed or disseminated by interested parties in any way: especially in the case of older works not (yet?) in the major players' portfolios, the ban on formalities denies certainty in domestic and international negotiations, making often difficult if not completely impossible - to reconstruct the proper chain of these titles. Many works remain totally unexploited for these reasons: EU copyright law has not yet provided a full and special regime for orphan works $s^{147}$. From this point of view, the Berne ban on formalities could be an incentive to let old-fashioned or romantically poor authors be protected without registration fees or deposit costs: on the contrary the professional nature of today's authors, from free-lancers to corporations, would tend to impose formalities to allow both right holders and third parties to decide and to know what is actually worth protecting and what is not. On the contrary, however, not only does the ban still enforce any "small coin" per se, even absent the will to protect it under the Berne regime - so giving rise to a connected "automatic" plus "blanket" incentive, through the exclusivity for everyone's simplest creation, which is very hard to understand from a legal and economic perspective - but it has been totally extended to the "cultural" industries, again unbalancing the synallagmatic "contract" between proprietors and Society (see Article 5.b of EC Directive No 2004/48) 148 : in return for what the latter would grant and enforce exclusive rights to phono-

as a result of the unauthorized reproduction of his/her work - notwithstanding the obiter dictum that even Directive No 2001/29 requires a fair balance between rightholders and users with the acknowledgement of private copying as a "cultural" exception by the European Parliament Resolution of 22 September 2010 (supra, note 52), $\$ 2$.

147 Very limited and unsatisfactory seems the regime laid down by the final proposal for a Directive on certain permitted uses of orphan works of 24 May 2011 COM(2011) 289 final. On this subject-matter, see also van Eechoud, Hugenholtz, Guibault, van Gompel E Helberger, Harmonizing European Copyright Law (supra, note 144), pp. 263 et seq.

${ }^{148} \mathrm{It}$ is really marvellous the superficiality by which - even in EU Law - the rationale provided for individual authors has been automatically extended to all industries. See Recital No 19 of the same directive: "since copyright exists from the creation of a work and does not require formal registration, it is appropriate to adopt the rule laid down in Art. 15 of the Berne Convention, which establishes the presumption whereby the author of a literary or artistic work is regarded as such if his/her name appears on the work. A similar presumption should be applied to the owners of related rights since it is often the holder of a related right, such as a phonogram producer, who will seek to defend rights and engage in fighting acts of piracy". No consideration, of course, of the public interest in legal certainty or in archiving cultural heritage, remaining as the sole incentive to reward the industry's cost; no matter that the ban on formalities effectively applied to authors, but never to industries, whose products always required deposits or notices under Art. 11 of the Convention for the Protection of Performers, Producers of Phonograms and Broadcasting Organizations, Rome, 26 October 1961, still in force and adopted in relation to conditions, limitations, exceptions and reservations by Art. 14(6), TRIPs. 
gram producers, broadcasters, etc.? Why, furthermore, for books and other cultural products, are some administrative deposits still mandatory in many EU countries - in order to ensure legal certainty and cultural dissemination - since the Article V of the Statute of Anne ${ }^{149}$ ?

\section{The incentive paradigm extended to trade marks, design and model rights: does some room remain for the free circulation of industrial products or services?}

For an already "industrial” copyright in the knowledge society, the issues of dissemination and disclosure become as relevant as they are for in patents - notwithstanding the total lack of this consideration in the "social contract", unlike inventions, due to the traditional cultural domain of works of authorship ${ }^{150}$ especially in the case of new "technical” but also copyrightable items, like software, electronic databases, industrial designs and so on. If the dissemination of technical features in return for exclusivity was a main goal since the Statute of Monopolies and the Industrial Revolution in order to improve both ordinary peoples' lives and the industry competition - therefore making patent rules stricter, in relation to formalities, duration, etc., than copyright - the dissemina-

149 An "Act for the Encouragement of Learning, by vesting the Copies of Printed Books in the Authors or purchasers of such Copies, during the Times therein mentioned", enacted in 1709 and entered into force on April 10, 1710: its official title still reveals the underlying, but well-balanced, “incentive/access paradigm”. In particular, Art. V provided "that nine copies of each book or books, upon the best paper, that from and after the said tenth day of April, one thousand seven hundred and ten, shall be printed and published, as aforesaid, or reprinted and published with additions, shall, by the printer and printers thereof, be delivered to the warehouse keeper of the said company of stationers for the time being, at the hall of the said company, before such publication made, for the use of the royal library, the libraries of the universities of Oxford and Cambridge, the libraries of the four universities in Scotland, the library of Sion College in London, and the library commonly called the library belonging to the faculty of advocates at Edinburgh respectively; which said warehouse keeper is hereby required within ten days after demand by the keepers of the respective libraries, or any person or persons by them or any of them authorized to demand the said copy, to deliver the same, for the use of the aforesaid libraries; and if any proprietor, bookseller, or printer, or the said warehouse keeper of the said company of stationers, shall not observe the direction of this act therein, that then he and they so making default in not delivering the said printed copies, as aforesaid, shall forfeit, besides the value of the said printed copies, the sum of five pounds for every copy not so delivered, as also the value of the said printed copy not so delivered, the same to be recovered by the Queen's majesty, her heirs and successors, and by the chancellor, masters, and scholars of any of the said universities, and by the president and fellows of Sion College, and the said faculty of advocates at Edinburgh, with their full costs respectively".

150 See Roebl and Varian, Circulating Libraries and Video Rental Stores, December 1996 (as revised on March 9, 2000), available at http://people.ischool.berkeley.edu/ hal/Papers/ history/history.pdf. 
tion of culture in the "knowledge society" has also become essential, requiring more and more common rules for the public goods involved. However, since copyright has turned into industrial production rather than personal creation, its rules should comply with the patent regime, not vice versa, as has occurred under Article 5.b of EC Directive No 2004/48, extending the presumptive authorship without formalities to all kinds of "ownership": in addition, the more we depart from patents, the more that disclosure or dissemination looks restricted, unbalancing the scales again towards the incentive paradigm only. Under Article 62 of EC Regulation No 2100/94, the administrative decision to grant a Community plant variety right shall only include an official description of the variety ${ }^{151}$, while, shifting to more copyright-shaped legal hybrids, Article 4, second sentence of EEC Directive No 87/54, allows - but does not oblige Member States to enact that "material identifying or exemplifying the topography or any combination thereof has been deposited with a public authority", as well as a statement as to the date of first commercial exploitation of the topography where it precedes the date of the application for registration, in addition

${ }^{151}$ See e.g. the strict exemption for events in the EC Directive No 2007/65, amending EEC Directive No 89/552, on the coordination of certain provisions laid down by law, regulation or administrative action in Member States concerning television broadcasting activities, which introduces, in particular, Chapter IIC ("provisions concerning exclusive rights and short news reports in television broadcasting”). Under Recital No. 39, “in order to safeguard the fundamental freedom to receive information and to ensure that the interests of viewers in the European Union are fully and properly protected, those exercising exclusive television broadcasting rights to an event of high interest to the public should grant other broadcasters the right to use short extracts for the purposes of general news programmes on fair, reasonable and non-discriminatory terms taking due account of exclusive rights. Such terms should be communicated in a timely manner before the event of high interest to the public takes place to give others sufficient time to exercise such a right. A broadcaster should be able to exercise this right through an intermediary acting specifically on its behalf on a case-by-case basis. Such short extracts may be used for EU-wide broadcasts by any channel including dedicated sports channels and should not exceed 90 seconds. The right of access to short extracts should apply on a trans-frontier basis only where it is necessary. Therefore a broadcaster should first seek access from a broadcaster established in the same Member State having exclusive rights to the event of high interest to the public. The notion of general news programmes should not cover the compilation of short extracts into programmes serving entertainment purposes (...)" However, under Recital No 40, "the requirements of this Directive regarding access to events of high interest to the public for the purpose of short news reports should be without prejudice to Directive 2001/29/EC of the European Parliament and of the Council of 22 May 2001 on the harmonisation of certain aspects of copyright and related rights in the information society and the relevant international conventions in the field of copyright and neighbouring rights. Member States should facilitate access to events of high interests to the public by granting access to the broadcaster's signal within the meaning of this Directive"; nonetheless, Member States "may choose other equivalent means within the meaning of this Directive. Such means include, inter alia, granting access to the venue of these events prior to granting access to the signal. Broadcasters should not be prevented from concluding more detailed contracts". Accordingly, the right of access to short extracts remains subject to the three-steps test and to all other restrictions of Directive No 2001/29. 
to such registration ${ }^{152}$. Registration or other formalities - including mere copyright notices - have also been banned for industrial materials protected by neighbouring rights and even reverse engineering through decompilation, unlike topographies, is hyper-restricted under Article 6 of EEC Directive No 250/91, since "it has therefore to be considered that in these limited circumstances only, performance of the acts of reproduction and translation by or on behalf of a person having a right to use a copy of the program is legitimate and compatible with fair practice and must therefore be deemed not to require the authorization of the rightholder": however, even such an exception to the author's exclusive rights "may not be used in a way which prejudices the legitimate interests of the rightholder or which conflicts with a normal exploitation of the program" (Recitals Nos 21 and 23, emphasis added). A similar tautological and vicious circle is again expressed in Recital No 18 - regarding mere "external" experimental uses - where it is stated that a person having the right to use a computer program should not be prevented from performing acts necessary to observe, study or test the functioning of the program, "provided that these acts do not infringe the copyright in the program". No disclosure is expressly provided for as a basic principle for registered designs or models - notwithstanding their technical features - in the approximation of Member State's laws under EC Directive No 98/71 ${ }^{153}$ : only from EC Regulation No 6/2002 of 12 December 2001 on Community designs, is a disclosure of designs or models deemed to be compulsory, but their immediate availability to the public is subject to a very large exception, because the applicant for such a registered design may request, when filing the application, that the publication of the registered Community design be deferred for a period of 30 months from the date of filing or, if priority is claimed, from the date of priority. Upon such a request, the registered Community design shall be registered, but neither the representation of the design nor any file relating to the application shall be open to public inspection (Article 50.1 and 50.2$)^{154}$ : once again, this extraordinarily long period of secrecy - in comparison to patent applications - is granted on the grounds that normal pub-

152 Moreover, this optional disclosure risks disappearance at the rightholder's discretion under Art. 4.2, according to which "Member States shall ensure that material deposited in conformity with paragraph 1 is not made available to the public where it is a trade secret". This provision shall be without prejudice only to the disclosure of such a material pursuant to an order of a court or other competent authority to persons involved in litigation concerning the validity or infringement of the exclusive rights.

153 Art. 6 implicitly acknowledges that "a design shall be deemed to have been made available to the public if it has been published following registration or otherwise (...)".

${ }^{154}$ Like undisclosed applications for a patent, a residual guarantee of legal certainty is laid down in Art. 50.6: the institution of legal proceedings on the basis of a registered Community design during the period of deferment of publication shall be subject to the condition that the information contained in the register and in the file relating to the application has been communicated to the person against whom the action is brought. 
lication following the registration of a Community design "could in some cases destroy or jeopardise the success of a commercial operation involving the design", and, according to a one-way incentive paradigm, "the facility of a deferment of publication for a reasonable [!] period affords a solution in such cases"155. The additional protection of unregistered designs or models under Article 11 of EC Regulation No 6/2002 is another issue intended only to foster "small coins" in this area, despite the legal certainty for competitors and users: like unregistered trade marks and slavish imitation, indeed, disclosure is taken into here account only in terms of factual availability to the public and, in particular, if the design or model has been published, exhibited, used in trade or otherwise disclosed in such a way that, in the normal course of business, these events could reasonably have become known to the circles specialised in the sector concerned, operating within the Community. According to Recital No 21, "the exclusive nature of the right conferred by the registered Community design is consistent with its greater legal certainty", while "it is appropriate that the unregistered Community design should, constitute a right only to prevent copying": therefore, protection could not extend "to design products which are the result of a design arrived at independently by a second designer", but "this right should also extend to trade in products embodying infringing designs" 156 . The adequacy of EU Law's attempt to mediate between legal certainty and maximum incentive to protection without legal formalities or cost is, however, doubtful because - as demonstrated in the case of copyright - independent creation defences, if any, are often impossible to prove in a globalised world ${ }^{157}$ : moreover, the unregistered design right holder enjoys similar facilities as the registered right holders, since in proceedings concerning an infringement action or an action for threatened infringement of an unregistered Community design, the Community design court shall treat the Community design as valid if the right holder produces proof that the conditions laid down in Article 11 have

155 Recital No. 26.

156 See Art. 19.2: an unregistered Community design shall confer on its holder the right to prevent the acts referred to in paragraph 1 only if the contested use results from copying the protected design. However, the contested use shall not be deemed to result from copying the protected design if it results from an independent work of creation by a designer who may be reasonably thought not to be familiar with the design made available to the public by the holder.

157 Compare the alleged doctrine on rencontres fortuites with the U.S. First Inventor Defense Act, Pub. L. No. 106-113, 113 Stat. 1536 (1999), codified at 35 U.S.C. \$273(b), providing that an earlier inventor of a method of doing or conducting business - later patented by another - might assert a defense to a claim of patent infringement only in certain circumstances; would both the rencontres fortuites been protected in EU Design and Copyright Law, as virtually stated by the U.S. Supreme Court in Sheldon v. Metro Goldwyn Pictures Corp., 81 F.2d 49 ( $2^{\text {nd }}$ Cir. 1936), if "by some magic a man who had never known it were to compose anew Keats's Ode on a Grecian Urn” (correctly criticized by Litman, The Public Domain, in 39 Emor. Law Journ. pp. 965 et seq., at p. 1000 (1990)? 
been met and indicates what constitutes the individual character of his Community design (Article 85.2) ${ }^{158}$. Until the end of last Century, EU attempts to reward any kind of petty invention or trivial work, through the same exclusive pattern originally provided for higher creative innovations, was prevented by the persistent need to fairly balance incentive and access, as well as exclusivity and competition (see e.g. the ultimate refusal to enact the proposed directives on utility models in 2005 or software patents in 2007) ${ }^{159}$ : the final enactment of such an extensive protection for designs and models including technical issues, with very low originality and eventually cumulated an pair with copyright protection - but without formalities for legal certainty or selective granting ${ }^{160}$ seems without total regard to the free circulation of goods on which the harmonization is nominally based. This one-way incentive only to protect the private assets of businesses is self-evident here: "a Community design should, as far as possible, serve the needs of all sectors of industry in the Community". Indeed, "some of those sectors produce large numbers of designs for products frequently having a short market life where protection without the burden of registration formalities is an advantage and the duration of protection is of lesser significance, while different sectors of industry value the advantages of registration for the greater legal certainty it provides and which require the possibility of a

158 The defendant may only contest its validity by way of a plea or with a counterclaim for a declaration of invalidity (Art. 85.2, last sentence).

159 Amended proposal for EC Directive approximating the legal arrangements for the protection of inventions by the utility model, 25 June 1999, COM(1999) 309 final/2, 97/0356 (COD); for strong criticism of this proposal, see Ghidini, Innovation, Competition and Consumer Welfare (supra, note 27), pp. 65 et seq, or many other comments quoted by EC Commission, Summary report of replies to the questionnaire on the impact of the Community utility model with a view to updating the Green Paper on protection by the utility model in the internal market, 1 March 2002, SEC(2001)1307. Once again - according to Recitals Nos 1 and 4 of the proposal - "the Treaty commits the Community and Member States to creating the conditions for Community industry to be competitive and to promoting a better exploitation of the industrial potential of innovation, research and technological development policies", making "important in this context to employ every possible means of increasing the competitiveness of Community industry in the field of research and development". Accordingly, the utility model was considered to involve an innovative step if it exhibited an advantage, and, having regard to the state of the art, this was "not very obvious" to a person skilled in the art (Art. $6, \mathbb{1} 1$, emphasis added): the advantage referred to in the previous paragraph had to be "a practical or technical advantage for the use or manufacture of the product or process in question, or another benefit to the user", e.g. for education or entertainment $(\$ 2)$.

160 However - according to Recital No 18 - the registered Community design system should, in principle, not be based upon substantive examination as to compliance with requirements for protection prior to registration, thereby keeping to a minimum the registration and other procedural burdens on applicants. Attempts at more selective protection still remain in Recital No 14, which states that individual character should be based on whether the overall impression produced on an informed user viewing the design "clearly differs" from that produced on him by the existing design corpus: such a higher level of originality disappeared from Art. 6 and it is now critical to reaffirming a selective principle on these grounds. 
longer term of protection corresponding to the foreseeable market life of their products" (Recital No 15 and 16): "this calls for two forms of protection, one being a short-term unregistered design and the other being a longer term registered design" (as concluded in Recital No 17). The basic grounds for protection seems to display no consideration of the other parties to the "social contract": legal certainty also seems to only be considered from the point of view of the industries seeking exclusive rights and not in the interest of competitors or users, who walk in a minefield, in which prior (higher or lower) creations - even unregistered - may blow up at any step. The incentive for the incumbent right holders thus becomes a strong disincentive for every new-comer on that field, whom not even the most expensive research reports on the registered state-ofthe-art can insure from possible damages or future disinvestment of his/her assets ${ }^{161}$ : it was often argued, in response to this concern, that the more trivial works or inventions also have a lower protection, but this defense is so superficial to be simplistic at the least, because, on one hand, so many (low) inventions or works contribute to the cumulative effect of an inextricable jungle of (higher) creative innovation - such as the minefield example above - and, on the other, this observation might only be worthwhile at a production-stage level. Indeed, once the (lower) work or invention has been produced and commercialised, goods incorporating these intangible assets are no longer replaceable by others, thus preventing many uses by third parties: if a protected "small coin", such as an earring, is used by an actor on the stage or a simple sculpture is put in a public square, anybody may perhaps easily produce a different earring or create a

161 The minefield for the competitors and the "rights jam" for third parties described above - due to the excessive fragmentation of too many (low and unworthy) IP titles - is known in the economic literature as the "tragedy of the anti-commons" (Heller, The Gridlock Economy. How Too Much Ownership Wrecks Markets, Stops Innovation, and Costs Lives (2008), pp. 1 et seq.). As for patents, see OECD, Competition, Patents and Innovation (supra, note 47): "not very long ago, a company working on a new product might have had to be wary of a handful of relevant patents and make sure that it either designed around them or obtained a license. It was relatively easy to know what to watch out for, to sidestep it if possible or to negotiate licenses to it if necessary. Today, however, a firm designing a high-tech product may need to wade through thousands of potentially problematic patents to avoid infringing them. More patents per year are being awarded than ever before, and the rate is continuing to climb. Significant changes in patent policies in recent years have made it easier to obtain patents in general and in some jurisdictions the scope of what is patentable has been extended to include genetic inventions, software, and business methods. Furthermore, other changes have made it easier to enforce patent rights and have stiffened the legal consequences of infringement. The effects of these changes on innovation are not entirely clear yet, but together they have raised concerns that the effects are actually negative. For example, some worry that a 'patent thicket' has developed. That is, there is a concern that so many patents are issued now that innovation is being discouraged because it has become too difficult, too time-consuming, and too expensive for innovators to navigate around everyone else's patents", so that, "with certain exceptions, it can be said that patent appear to be playing a relatively small role in innovation". 
different sculpture ${ }^{162}$, but nobody can $e . g$. take a picture of the object or the actor if he or she has not (a) obtained the prior right holder's consent or (b) paradoxically substituted the actor or even... the square ${ }^{163}$ ! The above mentioned conclusion is perhaps more relevant in the case of models, designs and trade marks: not all products or services are (yet?) patented, but, due to the very low individual character required under Article 5 of the EC Directive No 98/71, any registered or unregistered design right holder may totally prevent the making, offering, putting on the market, importing, exporting or using of all products into which the design is incorporated or to which it is applied, plus the stocking of the products for such purposes (Article 12.1): the same happens for branded goods, especially when the trade mark is the Ausstattung of the product itself (as for three-dimensional trade marks $)^{164}$, or - by secondary meaning - prevents competitors and third parties to use common words or shapes ${ }^{165}$. The intellectual property in models, designs or trade marks - from worthless and unregistered chattel to dressmaking - overlaps with the material proprietor's rights to dispose of his/her own belongings and inverts the odds once again between the rule and the exception laid down in Article 30, EC Treaty: this invasive trend of the intellectual property is more evident when ordinary commodities

162 But is not an easy task, when considering the dozens of similar earrings or sculptures already protected with or without formalities. The examples mentioned have their origin respectively from the U.S. case Davis v. The Gap, Inc., 2nd Cir., April 3, 2001, and from the "Buren" case (App. Lyon, March 20, 2003, in Comm. com. électr., 2003, No 81). The latter decision was reversed by the French Court of Cassation, March 15, 2005, briefly holding that protected sculptures in a public square can be (reproduced and) communicated to public through postcards, if these are only "an element" of the whole landscape; but, on doubts that such reversal is genuine, Geiger, Creating Copyright Limitations without Legal Basis: The "Buren" Decision, a Liberation?, in 36 IIC 042 et seq. (2005).

163 Compare ECJ, case C-299/99, Philips v. Remington, [2002] ECR I-5475 - holding that the aim of Art.3(1)(e)(ii) of EEC Directive No 89/104 is to prevent the registration of shapes whose essential characteristics perform a technical function, with the result that the exclusivity in the trade mark right would limit the possibility of competitors supplying a product incorporating such a function or at least limit their freedom of choice with regards to the technical solution they wish to adopt in order to incorporate such a function in their product", so that, "even if other shapes could achieve the same technical result as the shape sought to be protected as a trade mark, this did not overcome an objection raised under this provision" with Clark, Lucasfilm Ltd v. Ainsworth: The Force of Copyright Protection for Three-Dimensional Designs as Sculptures or Works of Artistic Craftsmanship, [2009] EIPR 384 et seq.

${ }^{164}$ Compare Hays, The Free Movement (or not) of Trademark Protected Goods in Europe, in Dinwoodie \& Janis (eds.), Trademark Law and Theory (supra, note 138), pp. 204 et seq., with ECJ, case C-529/07 (Lindt Goldhase), concerning a trade mark application intended to prevent competitors from continuing to market similar goods (traditional Easter bunnies, made with chocolate, which had previously acquired an alleged "secondary meaning" as an exclusive trade mark).

165 See ECJ, case C-102/07 (Adidas II) affirming that the requirement of availability (Freibaltebedürfnis) cannot be taken into account in the assessment of the scope of the exclusive rights of the proprietor of a trade mark, except in so far as the limitation of the effects of the trade mark defined in Article 6(1)(b) of EEC Directive No 89/104 applies. 
are copyrighted, preventing all economic use, rental, exhibition, etc., of genuine goods by the lawful material proprietor (see e.g. Article 5.3,j, $l$, and $m$, of EC Directive No 29/2001, which only grants a "benevolent" exception allowing material proprietors to use the works in connection with repairs or demonstrations of equipments, or to use an artistic work in the form of a building or a drawing or a plan of a building for the purpose of reconstructing the building, or, finally, to use these works for advertising their public exhibition or sale, to the extent necessary to promote such events, excluding any other commercial use). Such extensions of the incentive to create for individual profit, but not to disseminate, are particularly critical: not only are these extensions an obstacle to many ordinary uses of the work by the material proprietor - although often "granted" as strict exceptions ${ }^{166}$ - but they also give rise to a sort of monopolistic "spillover" effect towards secondary or non-competitive markets or uses, which, according to the Magill doctrine ${ }^{167}$, may be deemed to prohibit more than to foster the dissemination of innovative creations under the basic EU principles for balancing exclusive and access rights. The same criticisable extension has ultimately been laid down for design or model rights under Article 13.2 of EC Directive No 98/71, where (once again...) repair appears to be allowed only for equipment on ships and aircraft registered in another country, when these temporarily enter the territory of the Member States - besides the transitional provisions on spare parts, under Article $14^{168}$ - while, a contrariis, even mere photos or drawings of any industrial product embodying a design or model, outside of the strict "teaching exemption" under Article 13.1..$^{169}$, seems to be completely prohibited. A shy attempt to restore the original principle of balancing material goods and intangible assets might be seen in Article 2.3 of EC Directive No 92/100170, which does not implement rental and lending rights "in relation to buildings and to applied art":

166 See e.g. Art. 6 of the EC Directive 96/9, entitled "Exceptions to restricted acts" and providing (para. 1) that the performance by the lawful user of a database or of a copy thereof of any of the acts reserved to the right holder which is necessary for the purposes of access to the contents of the databases and normal use of the contents by the lawful user shall not require the authorization of the author of the database. Where the lawful user is authorized to use only part of the database, this provision shall apply only to that part". It is clear how this "exception" corresponds to the ordinary task of a database for any of its users: see Mazziotti, EU Digital Copyright Law and the End-User (2008), pp. 77 et seq.

167 ECJ, joined cases C-241/91 and C-242/91, Magill, [1995] ECR I-743, para. 56.

168 Kur, Freeze Plus Melts Ice. Observations on the European Design Directive, 30 IIC 620 et seq. (1999).

169 The rights conferred by a design right upon registration shall not be exercised in respect of (...) acts of reproduction for the purposes of making citations or of teaching, provided that such acts are compatible with fair trade practice and do not unduly prejudice the normal exploitation of the design, and provided that mention is made of the source. Under the TRIPs regime, see De Borja, Exceptions to Design Rights: The Potential Impact of Art. 26(2) TRIPs, [2008] EIPR 500 et seq.

170 Now Art. 3.2 of EC Directive No 2006/115. 
without this provision, again, the rental of a bicycle or the lease of a flat by its lawful owner should be prohibited if not authorised by the architect or the designer (i.e. by the right holder of the work of authorship embodied in, or applied to, the material good). This provision might be more valued as a ground to stop the "spillover" effect described above: in addition, it demonstrates how much "legal antibodies" seem to be necessary among the principles of EU Law from "within" the IP system, in order to prevent the extensive effects of the incentive paradigm ${ }^{171}$, rather than applying exogenous or general antitrust provisions case by case, subject to discretionary rules and to some degree of market power which can not exist in single transactions or uses ${ }^{172}$; international exhaustion should also be taken into account when the goods parallel-imported have almost similar prices abroad or do not present any other objection - as supported by Article 7.2 of the EEC Directive No 89/104 $4^{173}$ - otherwise not enjoying the right holder an incentive to produce or create, but a second, third, etc., monopolistic reward for the distribution of the same goods already lawfully placed into the global market, while the competitive resale of genuine goods is hampered ${ }^{174}$. More dangerously, the European Court of Justice has preempted the Community exhaustion too, when the resale of the branded goods - as happens in discount stores - may damage the allure and prestigious image which bestows on these goods an "aura" of luxury ${ }^{175}$ : this conclusion is grounded on the increasing European Court's trend to grant trade marks not only an "advertising” Werbefunktion - in addition to the main Herkunftsfunktion - but a further and discrete "investment function" 176 that must be protected and "incentivised" as well as all other finan-

171 Especially when trade marks are no longer protected only for their distinguishing function, but also as "value" as such: for criticism of the European "reform" of EEC Directive No 89/104, as risking going too far in protecting trade marks beyond this main function, Ghidini, Innovation, Competition and Consumer Welfare (supra, note 27), pp. 156 et seq.

172 This is the reason that, for instance, in some Member States, the abuses of a (relative) dominant position in merely contractual relationships have been sanctioned in addition to abuses of a dominant position in the market: in Germany, for instance, see $\$ 20.2 \mathrm{GWB}$. For deeper analysis, Lange, Klippel E Obly, Geistiges Eigentum und Wettbewerb (2009).

173 It is, therefore, a quite reasonable new way in which to read both the international and the EU provisions in the light of a more balanced perspective of the public interest: see Reichman, in Yusuf \& Correa (eds.), Intellectual Property and International Trade: TRIPs Agreement, $2^{\text {nd }}$ ed. (2008), pp. 33 et seq.

${ }^{174}$ For similar conclusions on the limited exhaustion in the framework of the incentive paradigm, see Guellec, Patents as an Incentive to Innovate, in Guellec \& van Pottelsberghe de la Potterie (eds.), The Economics of the European Patent system (supra, note 95), pp. 79 et seq.

175 See e.g. ECJ, C-59/08 (Copad case). In this case, the resale to discount stores concerned goods put on the market in disregard of a provision in the licence agreement - therefore lacking the trade mark holder's consent, under Article 7(1) of EEC Directive No 89/104 - but the conclusion of the Court, referred above, is more general and also applicable to legitimate resales on the grounds of Article 7(2) of the same Directive.

176 See ECJ, C-239/09 (Interflora case); ECJ, C-487/07 (L'Oréal case). By adding a further "investment function" to the identifying, quality or advertising function, the European 
cial investment (therefore shifting the trade marks from distinctive signs in favour of consumer and competition to powerful weapons for monopolizing the market through words, images or products' shapes, and making a "vicious circle", which can lead well-known marks to extend their exclusive rights to goods or services far from their distinctive origin or against legitimate sales, if considered unworthy of the "aura" of the branded merchandise) ${ }^{177}$.

\section{Extending the duration of IP Rights: an incentive to produce more creative innovation or the protection of an incumbent mortmain?}

The increasing terms of duration of all IP rights is perhaps the most clear evidence of the incentive paradigm's hypocrisy: if the increased protection were extended only on future creations, such an incentive might be said to be too large, yet still real ${ }^{178}$. Given that this prolongation is systematically extended by

Court has critically gone too far away the Recital No 11 of EC Directive No 2008/95 - still declaring that the function of a trademark, in particular, is to guarantee the indication of origin - making trade marks more comparable to... multifunction printers than to distinctive signs.

177 As remarked by Burrel, Trade mark bureaucracies, in Dinwoodie \& Janis (eds.), Trademark Law and Theory (supra, note 138), p. 95 and note 1, the justification for trade mark protection focuses "on the arguments that trade marks reduce consumer search costs and protect against misappropriation of other traders' labour and investment": in this perspective, trademarks traditionally "provide traders with incentives to compete on grounds other than price by developing products with particularly desirable properties. It should also be noted that some of the more recent law and economics literature seeks to go beyond the consumer confusion/search cost argument and suggests that trade mark protection provides incentives for traders to invest in the development of new signs" (or in the expansion of the existing ones). As for the literature in question, the Author-in particular - quotes Chiappetta, Trademarks: More than Meets the Eye, [2003] U.Ill. J.L. Tech. \& Pol'y 35; Richardson, Trade Marks and Langauge, 26 Sidney L. Rev., 193 [2004]; Landes E Posner, The Economic Structure of Intellectual Property (supra, note 29), pp. 168 et seq.

178 This extension - grounded on the "fig leaf" of the average heir's increasing life expectancy nowadays (see Recital No 5 of EC Directive No 93/98) - is paradoxical for software, in relation to the (ten years) topographies protection under Art. 7.3 of Directive 87/54/EEC, complying with Art. 38 TRIPs. This trend seems however unstoppable: for some criticism, compare Hilty \& Others, Comment by the Max Planck Institute on the Commission's Proposal for a Directive to Amend Directive 2006/116 Concerning the Term of Protection for Copyright and Related Rights (2009), 2009, EIPR, 31, pp. 59 et seq., with - at least - the need of accompanying measures in order to rebalance the contracts whereby the performers transfer their exclusive rights to phonogram or audiovisual producers, affirmed by the European Parliament, Legislative Resolution of 23 April 2009 on the Proposal for a Directive of the European Parliament and of the Council Amending Directive 2006/116/EC of the European Parliament and of the Council on the Term of Protection of Copyright and Related rights (2010/C $184 \mathrm{E} / 69)$, para. 10 et seq. 
EU Law to all (already existing) rights in respect of every (already created) innovation, the incentive rationale is far from justified and a Middle-Age "mortmain" on "static" estates might more accurately be said to have returned, according to the growing financial rationale of the IP rights' framework as a main "situation rent"179. A retrospective increase in the duration of protection - reversing the basic principle of non-retroactivity in Europe, laid down e.g. in Article 18.1 of the Berne Convention - not only creates "zombie works" in addition to "patent trolls" 180 , but acts as a discouraging sword of Damocles to all investment (especially in the case of derivative works, which have already fallen or which are falling into the public domain) ${ }^{181}$. In addition, notwithstanding the (merely virtual) protection of acquired rights - see e.g. Recital No 27 and Article 10 of EC Directive No 93/98 ${ }^{182}$ - a Member State seems to have no discretion in balancing this transitional period, under a strict interpretation of the incentive paradigm in the EU legal system, even if a European provision expressly allows each Member State to define the extent to which, and the conditions under which, the "new" protection is conferred (see Article 17, last sentence, of EC Directive No 98/71) ${ }^{183}$. The survival of already acquired rights in respect of a full

179 Compare the Statutes of Mortmain - enacted in 1279 and 1290 by King Edward I of England for preserving his revenues by preventing lands from passing into the possession of the Church - with the static wealth got by Fafner ("Ich lieg und besitz: laßt mich, schlafen!") in R. Wagner's Siegfried, Act II, Scene 2, premiered at Bayreuth Festspielhaus on August 16, 1876.

180 Geller, Zombie and Once-Dead Works: Copyright Retroactivity After the E.C. Term Directive, in 18 Entert. \& Sports Lawyer, n. 2, pp. 7 et seq. (2000).

181 See, e.g., the "Rear Window" case (Stewart v. Abend, 495 U.S. 207, 1990), where the U.S. Supreme Court granted damages and a portion of the movie's profits to a literary agent, who, in 1972, had acquired the copyright in Woolrich's tale "It Had to Be Murder" for US. $\$ 650$ (the Court, at least, denied the injunction to inhibit the communication of the movie to the public). As a matter of fact, the original author, who had to renew the movie rights when the copyright term expired, died in 1968 before he could officially do so, thus leaving the moviemaker free to adapt his tale since the copyright had been deemed to have expired. Until the "Rear Window" case, the leading decision in point was "Rohauer v. Killiam Shows" (Court of Appeals, 2nd Circuit, N.Y, 1977), holding that the owners of a derivative work could continue to use it, as they had before the original author's death, if the right was not officially renewed. Which incentive to create or disseminate, under such an extended proprietary regime, may be therefore deduced from this example?

182 According to Recital No 27, "respect of acquired rights and legitimate expectations is part of the Community legal order (...). Member States may provide in particular that in certain circumstances the copyright and related rights which are revived pursuant to this Directive may not give rise to payments by persons who undertook in good faith the exploitation of the works at the time when such works lay within the public domain”. Art. 10(3), second sentence, however, obliges Member States to "adopt the necessary provisions to protect in particular acquired rights of third parties", only exempting acts of exploitation performed by third parties before the date of the directive's entry into force (first sentence).

${ }_{183}$ See the reference for an ECJ preliminary ruling (Case C-168/09, O.J., 18 July 2009, C 167, p. 5) on the following questions: 1) must Art.s 17 and 19 of the EEC Directive 98/71/EC be interpreted as meaning that, in implementing a national law of a Member State which has introduced copyright protection for designs into its legal order in accordance with that Directive, 
revival of "zombie-works", on the contrary, might be more or less adjusted to the "importance" of each sector, where some producers may be lawfully "more equal" than others in order to the bitter consequences of such revival ${ }^{184}$. Finally,

the discretion accorded to such a Member State to establish independently the extent to which, and the conditions under which, such protection is conferred may include discretion to preclude such protection in the case of designs which - albeit meeting the requirements for protection laid down in copyright law - fell to be regarded as having entered into the public domain before the date on which the statutory provisions introducing copyright protection for designs into the domestic legal order entered into force, in so far as they had never been registered as designs in so far as the relevant registration had already expired by that date? 2) If the answer to the first question is in the negative, must Art.s 17 and 19 of Directive 98/71/EC be interpreted as meaning that, in implementing a national law of a Member State which has introduced copyright protection for designs into its legal order in accordance with that Directive, the discretion accorded to such a Member State to establish independently the extent to which, and the conditions under which, such protection is conferred may include discretion to preclude such protection in the case of designs which - albeit meeting the requirements for protection laid down in copyright law - fell to be regarded as having entered into the public domain before the date on which the statutory provisions introducing copyright protection for designs into the domestic legal order entered into force and where a third party - without authorisation from the holder of the copyright on such designs - has already produced and marketed products based on such designs in that State? 3) if the answers to the first and second questions are in the negative, must Art.s 17 and 19 of Directive 98/71/EC be interpreted as meaning that, in implementing a national law of a Member State which has introduced copyright protection for designs into its legal order in accordance with that Directive, the discretion accorded to such a Member State to establish independently the extent to which, and the conditions under which, such protection is conferred may include discretion to preclude such protection in the case of designs which - albeit meeting the requirements for protection laid down in copyright law - fell to be regarded as having entered into the public domain before the date on which the statutory provisions introducing copyright protection for designs into the domestic legal order entered into force and where a third party - without authorisation from the holder of the copyright on such designs has already produced and marketed products based on such designs in that State, where protection is precluded for a substantial period (a period of 10 years)?

184 ECJ, case C-60/98, Butterfly Music, [1999] ECR I-3939: Art. 10(3) of the EEC Directive 93/98/EEC - harmonising the term of protection for copyright and certain related rights - does not preclude a provision of national law such as the provision which provides a limited period in which sound-recording media may be distributed by persons who, by reason of the expiry of the rights relating to those media under the previous legislation, have been able to reproduce and market them before that Law entered into force, even if the term was longer or even endless for acquired rights on other media or works (books and literary works). The Court has shared the phonogram producers' arguments that the more favourable treatment accorded to publishers of literary works which have entered into the public domain was justified by the higher investment costs which they must normally bear and that Member States have full discretion on the point by fixing different terms for different kinds of works or materials: this rationale is even ironic since related rights of the phonogram producers in respect of phonograms - which do not exist for book publishers - have been always justified (on the contrary) by the higher investment costs of the latter. More recently, however, compare ECJ, case C-168/09, Flos, affirming - in a more balanced perspective - that "the absence of a provision expressly referring to protection, for third parties, of acquired rights and legitimate expectations in relation to the revival of copyright protection provided for in Article 17 of Directive No 98/71 does not preclude application of the principle that acquired rights must be respected or the principle of legitimate 
most of these terms of protection are not justified by any rule-of-reason test, if applied e.g. to software, especially when compared to the more reasonable and balanced ten year duration of rights on firmware under Article 7.3 of EEC Directive No $87 / 54$, according to TRIPs ${ }^{185}$ : this confirms, once again, that "one size doesn't fit all” and to what extent a maximum term of duration can hopefully be even more suitable when shared across multiple periods of protection - like the EU registered design or model regime, as well as is provided for the renewal fees of European patents under Article 141.1 of the European Patent Convention, but unlike copyright in the Berne system - to be not automatically prolonged as a mere "situation rent", but only if the right holder has a worthy and selected incentive to do $\mathrm{so}^{186}$.

expectations, both of which are among the fundamental principles of European Union law": as a consequence, "in that regard, the assessment of the compatibility of the length of that transitional period and of the category of third parties covered by the legislative measure must be carried out in the light of the principle of proportionality" ( $\int S 50$ and 56).

${ }^{185}$ A more dangerous duration - because it is potentially perpetual - already exists in the EU protection of sui generis databases: any substantial change, evaluated qualitatively or quantitatively, to the contents of a database, including any substantial change resulting from the accumulation of successive additions, deletions or alterations, which would result "in the database being considered to be a substantial new investment", evaluated qualitatively or quantitatively, "shall qualify the database resulting from that investment for its own term of protection" (see Art. 10.3 of EC Directive No 96/9). Although the "new" duration should be limited to the "new" data only, some commentators and the practice often blur the outlines between new and old data, already in the public domain, especially in the case of "dynamic" databases: compare on this point the critical observations by Ghidini, Innovation, Competition and Consumer Welfare (supra, note 27), pp. 134 et seq., or by Reichman E P. Samuelson, Intellectual Property Rights in Data? (1997), 50 Vand. L. Rev., pp. 51 et seq., with the further EC Directive, 17 November 2003, No 2003/98, granting to public sector bodies a "paracopyright" for the re-use of documents with or without conditions and, where appropriate, through a licence. In compliance with Article 8(1), these conditions shall not unnecessarily restrict possibilities for re-use and shall not be used to restrict competition, while, according to Recital No 22, "the intellectual property rights of third parties are not affected by this Directive. For the avoidance of doubt, the term 'intellectual property rights' refers to copyright and related rights only (including sui generis forms of protection). This Directive does not apply to documents covered by industrial property rights, such as patents, registered designs and trademarks. The Directive does not affect the existence or ownership of intellectual property rights of public sector bodies, nor does it limit the exercise of these rights in any way beyond the boundaries set by this Directive. The obligations imposed by this Directive should apply only insofar as they are compatible with the provisions of international agreements on the protection of intellectual property rights, in particular the Berne Convention for the Protection of Literary and Artistic Works (the Berne Convention) and the Agreement on TradeRelated Aspects of Intellectual Property Rights (the TRIPs Agreement). Public sector bodies should, however, exercise their copyright in a way that facilitates re-use". See Derclaye, Does the Directive on the Re-use of Public Sector Information affect the State's database sui generis right?, in Gaster, Schweghhofer E Sint (eds.), Knowledge rights - legal, societal and related technological aspects (2008), pp. 137 et seq.

186 As supported by Lessig, Free Culture (2004), pp. 287 et seq., in the U.S. Copyright system, also after the U.S. Berne Convention Implementation Act of 1988. 


\section{Conclusion: which EU principles in IP Law might more aptly mitigate and properly rebalance the present blanket incentive for protecting (low or high) creative innovations?}

To the detriment of the public interest, also in the European IP Law a oneway and market-oriented trend has prevailed in the last decades, heavily turning the balance of the social contract between creative innovators and society, from its original synallagmatic relationship, towards the investors' protection or to private economic rewards only. In particular, if a high-level protection may still be deemed to be an appropriate incentive for high-level investment in works and inventions, the same level of protection is quite unsuitable for more trivial works or inventions: EC rules ought therefore to deal with the drawbacks of such an absolute paradigm in the near future with more fair and tailor-made provisions: see $e . g$. the more balanced rules on the semiconductor topographies, in relation to the duration, the obligation to register and to disclose the protected item, the graduation of sanctions in the case of willful or innocent infringement, etc., in comparison to the strict, monopolizing and even unreasonable extent of protection of the scope, duration, etc., of software. The call for rules of competition laid down by Articles 81 et seq., of EC Treaty, is essential, but not sufficient, since an antitrust suit, as a matter of fact, is a long-term and very uncertain matter that not all interested parties might be able to bring, and as a matter of law, presumes a position of market/bargaining power, which, in intellectual property, can be eventual for competitors, but is more structural in respect of users ${ }^{187}$ : therefore, only "legal anti-bodies", already provided as such by EU Law on IP rights, are able to grant a more balanced environment for users, independently of right holders' degree of market power ${ }^{188}$. From this perspective, in addition to relevant exceptions and limi-

187 For the (doubtful) distinction between the existence of IP Rights and their exercise, see Jehoram E Smulders, The European Community and Copyright, in Geller (ed.), International (supra, note 5), $\mathbb{2}[1][b][i]$, pp. 31 et seq., with further critical references to these "vacillating doctrinal terms", giving rise to an obscure and illogical dichotomy, which provides potential immunity to every existing IP institution as such; Vernet, The Existence/Exercise Distinction: Helpful, Confusing, or Merely Obsolete? in Lidgard \& Atik (eds.), The Intersection of IPR and Competition (supra, note 32), pp. 153 et seq.

188 Another important issue, in order to reconcile IP grounds with the fundamental principles of workable competition and the free circulation of goods, is an interpretion of IP rights according to their function and not for the purposes of protection per se (as in the Infopaq case, supra, note 48), according to a more "static" perspective of "natural" rights. For this more functional point of view, see ECJ, case C-281/05, Montex v. Diesel, [2006] ECR I-10881, holding that transit, which consists in transporting goods lawfully manufactured in a Member State to a non-member Country by passing through one or more Member States, does not involve any marketing of the goods in question and is therefore not liable to infringe the specific sub- 
tations, more tailored-made limits from within the exclusive rights must be deemed fit to foster competition and dissemination as well, in the framework of an "incentive/access paradigm", once well grounded in the contract between inventors/authors and society as a whole ${ }^{189}$. If such a "social contract" is deeply rooted in the case of patents, one must not forget that, in both common and civil law, all exclusive rights - including copyright in England as well in Italy or France ${ }^{190}$ - arose from the privileges, granted by the sovereign, which might also be seen as agreements between the State and innovative creators and not as "natural" rights that might be acknowledged, at most, to exist as moral claims of paternity for anyone's substantial labour ${ }^{191}$. The development from privi-

ject-matter of the trade mark. The Court has made it clear that a trade mark proprietor cannot oppose the mere entry into the Community - under the external transit procedure or the customs warehousing procedure - of original goods bearing that mark which have not already been put on the market in the Community previously by that proprietor or with his consent. In the field of trade marks, placing non-Community goods bearing a mark under a suspensive customs procedure such as that of external transit is not, per se, interference with the right of the proprietor of the mark to control the initial marketing in the Community. The Court has, however, held that the trade mark proprietor can oppose the offering for sale or sale of original goods bearing a trade mark and having the customs status of non-Community goods, when the offering is done and/or the sale is effected while the goods are placed under the external transit procedure or the customs warehousing procedure and this necessarily entails their being put on the market in the Community. It follows that a trade mark proprietor can prohibit the transit, through a Member State in which that mark is protected (the Federal Republic of Germany, in the case), of goods bearing the trade mark and placed under the external transit procedure having another Member State as their destination where the mark is not so protected (Ireland), only if those goods are subject to the act of a third party while they are placed under the external transit procedure which necessarily entails their being put on the market in the Member State of transit. In that regard, the argument put forward by the trade mark holder that the mere risk that the goods could fail to reach their destination (namely in Ireland, in which the mark was not protected) and thus that they could theoretically be marketed fraudulently in Germany was sufficient to allow the conclusion that transit infringes the essential functions of the trade mark), was accordingly not accepted. In principle it was also held irrelevant whether goods, whose destination was a Member State, came from an associated State or from a third Country or whether those goods had been manufactured in the Country of origin lawfully or in infringement of the existing trade mark rights of the proprietor in that Country. On this case, see also Klopschinski, Markenverletzung im Transit, European Law Reporter 2006, 502 et seq.

189 For the TRIPs perspective to only allow external antitrust actions to prevent or sanction possible abuses (Art. 8.2), by strictly squeezing limitations or exceptions from within, see Shanker, Competition Policy and Prevention of Abuses in the TRIPs Agreement, in Cellini \& Cozzi (eds.), Intellectual Property, Competition and Growth (2007), pp. 207 et seq.

190 Supra, text and note 7.

191 Some attempts to find IP roots in religion or history reveal at most moral rights claims to paternity, such as Martialis' notion of plagiarism (supra, text and note 19), rather than exclusive rights of exploitation. Accordingly, the Talmud affirmation that he, who cites the source of his teaching, "brings salvation to the world", cannot "be interpreted as an economic incentive for producing and disseminating information", as alleged by Grandstrand, The Economics and Management (supra, note 21), p. 23, but only as moral acknowledment of the source. Moreover, even if economic rights are "natural", what is their extent? Would public lending also be a "natural" right in addition to the "copy"-right? See, e.g., the long and ana- 
lèges octroyées to full rights, means that intellectual property must be completely granted to anyone who meets the statutory requirements (with no further discretionary judgment), but it does not mean that intellectual property must stand alone and totally independent from the society that has granted it, without any consideration (quid pro quo) for public interests. All intellectual property is granted in exchange for the common welfare: such an individual and exclusive power to profit from one own's investment in an intangible asset may never be severed from the exceptional character of this power and its synallagmatic relationship ${ }^{192}$. Selective incentives for (true) innovative creation - through higher standards of worthy originality - should therefore be discerned from static mortmain, which only aims to protect the incumbents' goodwill, as unselective aids or blanket subsidies do, while limits, limitations and exceptions should act from within and more broadly so as not to hamper the fair exercise of the incentive rationale ${ }^{193}$, but (a) to allow an ordinary circulation (or

lytical list of pretended natural rights - including rights which include knocking at a door before entering or not asking embarrassing questions - argued by Röder, Grundzüge des Naturrechts oder der Rechsphilosophie (1860-1863), p. 91 et seq., ironically commented upon by von Jhering, Scherz und Ernst in der Jurisprudenz (1904), p. 332. Moreover, if a moral right of paternity on everybody's action is commonly acknowledged and factually recognizable - see Ascarelli, Teoria della concorrenza e dei beni immateriali (1960), p. 766 et seq. - there seems no way to find, in the great book of nature, a rule on the minimum duration of a patent, on the three-steps-test or on the grant of an exclusive right (instead of an equitable remuneration or a public domain regime), which have been therefore settled only by statutory law as the clauses of a "social contract" with authors or inventors. On the dialogical relationship between the public domain and the intellectual property, see more widely Obly \& Klippel (Eds.), Geistiges Eigentum und Gemeinfreiheit (2007).

192 For a similar and critical reasoning on the Lockean "natural rights" of (intellectual) property, see Boyle, The Public Domain. Enclosing the Commons of the Mind (2008), pp. 27 et seq.; it would even be noted that the word "royalty" for payment, in all IP transfer agreements, still reveals this original granting. An attempt to bring all the IP rights - not only patents - back to their basic grounds of "social contracts", is also made by Dutfield E Suthersanen, Global Intellectual Property Law (2008), pp. 47 et seq., following Rawls, A Theory of Justice (1971), and adopting a multilateral approach to such an agreement, which involves all the stakeholders (at least: right-holders, competitors, end-users) as the parties.

193 Unlike EU Court of Justice in its overly strict rulings, only aimed at the static structure and not at the functions of IP rights in a framework which includes third parties' rights as well: see, e.g., the decisions quoted supra, at note 46 or 48. A light in the dark, however, might be seen in a recent decision of Court on European IP Law (ECJ, 22 December 2010, C-393/09, Bezpečnostní softwarová asociace v. Svaz softwarové ochranypara, supra, note 142), stating at para. 56-58 that "the graphic user interface can be its author's own intellectual creation. Nevertheless, if, in the context of television broadcasting of a programme, a graphic user interface is displayed, television viewers receive a communication of that graphic user interface solely in a passive manner, without the possibility of intervening. They cannot use the feature of that interface which consists in enabling interaction between the computer program and the user. Having regard to the fact that, by television broadcasting, the graphic user interface is not communicated to the public in such a way that individuals can have access to the essential element characterising the interface, that is to say, interaction with the user, there is no communication to the public of the graphic user inter- 
non-competing uses) of goods to remain free and $(b)$ to counter-attack blocking strategies or other IP misuses which affect competitors or end-users. The following examples of some "genetic" antibodies from within - in the legal structure of the EU principles on intellectual property - might be stressed in order to demonstrate how the incentive paradigm for the right holders must be balanced by proper weight in granting incentives for a dynamic framework of innovative creation and for common welfare, in the public interest of both final or intermediate users and competing enterprises independently of (and in addition to) the antitrust rules, which may play their role only if a certain degree of market power is involved:

- as for patents, the "research exemption", not yet generally affirmed in EU patent law, but declared in EC Directives related to patentable inventions only and to be strengthened against possible strict interpretations as an esential counter-incentive to improvements obtainable by third competitors (in this rightful perspective, see e.g. Article 10, $\$$, of EC Directive No 2001/83, on the Community Code relating to medicinal products for human use: "conducting the necessary studies and trials with a view to the application of $\int \mathbb{S} 1,2,3$ and 4 and the consequential practical requirements shall not be regarded as contrary to patent rights or to supplementary protection certificates for medicinal products"); see also Article 15(b) and (c) of EC Regulation 2100/94 (plant variety rights shall not extend to acts done for experimental purposes plus to acts done for the purpose of breeding or discovering and developing other varieties);

face within the meaning of Article 3(1) of Directive No 2001/29". Consequently, according to the Court, "television broadcasting of a graphic user interface does not constitute communication to the public of a work protected by copyright". These statements, strictly intended, are clearly wrong: a communication to the public does not involve an active or interactive audience (as expressly demonstrated by the "right to make the work available to the public", in active or interactive ways, in addition to the traditional broadcasting rights for more passive viewers of tv movies or live shows); the judgment, however, seems totally rightful if the "passivity" of the audience is construed according to a functional meaning, in the sense that a person watching the television does not views or uses these interfaces as the components of a computer program, but as incidental elements of an audiovisual work, with a function totally different from the scope of the protection granted to software. From this perspective, the judgment is very similar to the "Buren" decision, where the French Court of Cassation (supra, note 162) affirmed that a sculpture photographed as an element of landscape is neither a reproduction, nor a communication to the public, in the meaning of copyright law. On interfaces, see van Rooijen, The Software Interface between Copyright and Competition Law (2010), pp. 3 et seq.; on a "functional" protection of the IP rights - from industrial property to copyright - in order to balance all the interests at stake and to avoid the risks of an intellectual (hyper)monoplization, which would lead the IP protection from its functional role of genuine incentive for innovation and competition to an absolute and ontological hypostasis, enjoining also any "passive" (recte neither competing nor functional) use by third parties, see Musso, entries "Proprietà Industriale" and "Proprietà Intellettuale”, in Enciclopedia del Diritto, Annali, II, 2 (2008), respectively p. 884 and 894. 
- as for copyright, the "interoperability rule" laid down in Article 6 of the EEC Directive 91/250, although too strictly construed as "indispensable to obtain the information necessary to achieve the interoperability of an independently created computer program with other programs" under the tight conditions provided for in the same provision: would this principle be affirmed more broadly - independent from a dominant position in the relevant market - the "Microsoft" case in Europe on this point will probably be decided more easily ${ }^{194}$;

- as for designs and models, the "interconnection" provision in Article 7.2 of EC Directive 98/71, affirming that "a design right shall not subsist in features of appearance of a product which must necessarily be reproduced in their exact form and dimensions in order to permit the product in which the design is incorporated, or to which it is applied, to be mechanically connected to, or placed in, around or against another product so that either product may perform its function": in this way - as in software interoperability - both the production or distribution of alternative (but still functional) components by competitors and an effective choice among these components for end-users is granted;

- as for trade marks, Article 6.1(c) of the EEC Directive 89/104, declaring that a trade mark shall not entitle the proprietor to prohibit third parties from using it in the course of trade, "where it is necessary to indicate the intended purpose of a product or service, in particular as accessories or spare parts", provided that the use is in accordance with honest practices in industrial or commercial matters: although not so explicit as to allow for a more general exemption for "descriptive" or "nominative" uses, this provisions can be seen as an implicit principle balancing the exclusive rights of the owner in the course of trade with the fundamental need to quote or mention the sign in or-

194 See, inter alia, Commission welcomes new Microsoft proposals on Microsoft Internet Explorer and Interoperability, press release issued in Brussels, 24 th July 2009, MEMO/09/352. In turn, Mrs. N. Kroes, European Commissioner for Competition, added: "Without choice, competition will die, and without competition, innovation will die. This case is not just about competition today, it is about competition and innovation tomorrow, next month and next year" quoted by Neal, EU and Microsoft reach anti-trust agreement, October 7, 2009, at http://www.theinquirer.net/inquirer/news/1557845/eu-microsoft-reach-anti-trust-agreement. Also the European Parliament Resolution of 22 September 2010 (supra, note 52), $\mathbb{1 3}$, has called on the Commission to ensure that the measures aimed at strengthening the application of intellectual property rights in the internal market do not impinge on the legitimate right to interoperability, this being essential to healthy competition on the digital works distribution market, inter alia for the authors and users of free software; on the Microsoft case, see also Eagles E Longdin, Microsoft's Refusal to Disclose Software Interoperability Information and the Court of First Instance, [2008] EIPR 205 et seq.; more generally, Benabou, European Competition Law and Copyright: Where do We Stand? Where do We Go?, in Derclaye (ed.), Research Handbook on the Future (supra, note 140), pp. 543 et seq. 
der, once again, to foster the distribution of competing components or spare parts, and also to avoiding marking out a linguistic preserve belonging to the trade mark owner (whereas, in particular, exclusivity is even extended to mere advertising under Article 5.3.d $)^{195}$;

- as for topographies, Article 5.6 of EEC Directive 87/54, laying down the principle of "innocent infringement" by a person who, when he acquires a semiconductor product, "does not know, or has no reasonable grounds to believe", that the product is protected by an exclusive right: such an innocent infringer shall not be prevented from commercially exploiting that product, but, for acts committed after that person knows, or has reasonable grounds to believe, that the product is so protected, the Member States shall ensure that - on demand of the right holder - a court may require the payment of adequate remuneration, in accordance with the provisions of the applicable national law.

The last mentioned "principle" to take care of - for the purpose of (re)balancing the grounds of IP protection in EU Law - brings up to another important point: even if (and when) the incentive paradigm plays its proper role ${ }^{196}$, property rights are not necessarily the most efficient or correct way to implement it. In copyright, as well as in all other areas of intellectual property, the model of domain publique payant may assume increasing relevance in order to link third parties access rights to right holders' due rewards, thus acting as the typical pattern of an "access/incentive paradigm" illustrated above ${ }^{197}$. Such a pattern may

195 Therefore making it more difficult to distinguish between only "descriptive" uses and uses in the course of trade: see, e.g., ECJ, joined cases C-236/08 to C-238/08, Google France and others, on keyword advertising, that has not followed the Advocate General's opinion in a number of respects, holding that Art. 5(1)(a) of EEC Directive No 89/104 and Art. 9(1)(a) of EC Council Regulation No 40/94 on the Community trade mark, must be interpreted as meaning that the proprietor of a trade mark is entitled to prohibit an advertiser from advertising - on the basis of a keyword identical to that trade mark, which that advertiser has, without the consent of the proprietor, selected in connection with an internet referencing service - goods or services identical to those for which that trade mark is registered, in the case where that advertisement does not enable an average internet user, or enables that user only with difficulty, to ascertain whether the goods or services referred to therein originate from the proprietor of the trade mark or an undertaking economically connected to it or, on the contrary, originate from a third party. However - according to the judgment - an internet referencing service provider, which stores, as a keyword, a sign identical with a trade mark and organises the display of the advertisements on the basis of that keyword, does not use that sign within the meaning of Art. 5(1) and (2) of Directive No 89/104 or of Art. 9(1) of Regulation No 40/94. For some criticism to a perhaps too cautious approach to the above mentioned "functionalist" construction of IP rights in this case - however - see Obly, Keyword Advertising or Why the ECJ's Functional Approach to Trade Mark Infringement Does Not Function, (2010) 41 IIC, pp. 879 et seq.

196 Shavell \& van Ypserele, Rewards versus Intellectual Property Rights, in Journal of Law and Economics (2001), 525 et seq.

197 Supra, text and note 93. 
not only act ex ante - in the shape of compulsory, extended or voluntary public licences, enhanced by tax incentives, as, in the case of patents, in Article 43 of the Community Patent Agreement - but also ex post, by applying the liability rule, as a reasonable remuneration instead of full damages, when the property rule appears to be too strict at the stage of enforcement (for instance, in worthy cases of derivative innovation or creation) ${ }^{198}$ : the requirement of proportionality deducible from Article 3.2 and 12 of EC Directive No 2004/48 - notwithstanding the rigour of the provisions herestated ${ }^{199}$, even through an EU common approach of criminal law to the point in the near future ${ }^{200}$ - might be a legal ground for the proposed (re)balancing.

198 As for the U.S. perspective, compare a similar reasoning by Lemley $\&$ Shapiro, Patent Holdup and Royalty Stacking, 85 Tex. L. Rev. 1991 et seq. (2007), or Hopenhayn E Llobet, Rewarding Sequential Innovators: Prizes, Patents, and Buyouts in Journal of Political Economy (2006), pp. 1041 et seq., in patent law, with Geller, Hirosige v. Van Gogh: Resolving the Dilemma of Copyright Scope in Remedying Infringement, in 46 Journ. U.S. Copyright Society, 39 et seq. (1998) in copyright law. Some "anti-troll" provisions - especially aimed to prevent legal actions brought mainly for damages, through merely "financial" IP rights, rather than for preventing genuine infringements or true piracy - have been significantly introduced in U.S. patent law by the Leahy-Smith "America Invents Act" (Public Law No 112-29, 125 Stat. 284), signed by the U.S. President on 16 September 2011.

199 The European Parliament Resolution of 22 September 2010 (supra, note 52), $\$ 5$, has stressed that all measures taken to enforce IPRs must respect the Charter of Fundamental Rights of the European Union (in particular, Articles 7 and 8), as well as the European Convention for the Protection of Human Rights and Fundamental Freedoms (in particular, Articles $6,8,10$ ) and be necessary, proportionate, and appropriate within a democratic society, but has ambiguously recalled - in this connection - that intellectual property must be anyway protected under Article 17 ECFR.

200 Compare also Recitals Nos 17 and 25 of the same Directive, affirming that "the measures, procedures and remedies provided for in this Directive should be determined in each case in such a manner as to take due account of the specific characteristics of that case, including the specific features of each intellectual property right and, where appropriate, the intentional or unintentional character of the infringement"; therefore, in particular, "where an infringement is committed unintentionally and without negligence and where the corrective measures or injunctions provided for by this Directive would be disproportionate, Member States should have the option of providing for the possibility, in appropriate cases, of pecuniary compensation being awarded to the injured party as an alternative measure". See Reitzig, Henkel, \& Heath, Who Really Profit from Patent Infringements? Innovation Incentives and Disincentives from Patent Indemnification Rules (2002), Working Paper, LEFIC Center for Law and Economics, Copenhagen Business School (DK), and Hilty, Kur E Penkert, Statement of the Max Planck Institute for Intellectual Property, Competition and Tax Law on the Proposal for a Directive of the European Parliament and of the Council on Criminal Measures Aimed at Ensuring the Enforcement of Intellectual Property Rights (supra, note 114). 


\title{
Two Tiered Protection - Designs and Databases as Legislative Models?
}

\author{
Annette Kur
}

\section{Introductory Remarks: Where is the 'Model'?}

The question posed by the title of this paper seems to imply that European legislation on designs ${ }^{1}$ and databases ${ }^{2}$ is based on a two tier structure that might serve as a model for legislation in other fields. However, upon closer inspection, such a model is not so easily identified. It is true that in both cases, protection is granted in two different forms - registered and unregistered designs, or copyright and sui generis right- which arguably qualify as 'upper' and 'lower' tiers within both fields. The relationship between the two tiers within each model, however, is marked by a number of differences. Most importantly, while the legal category to which registered and unregistered industrial designs belong remains exactly the same, the sui generis right protecting unoriginal databases relates to subject matter which is altogether different from copyright. Also, industrial design legislation comprises protection on the national as well as on the Community level, whereas database protection is only implemented nationally. Rather than providing a single model, both regimes obviously have only few commonalities. Their most striking common feature - the two tier structure is due to the double purpose pursued by the legislation, which on the one hand aims to harmonise traditional forms of protection already existing in all Member States, and on the other hand lays a common ground for protection of phenomena previously forming part of an area which was only subject to rules against unfair competition or similar provisions. While this does not lead to congruence in every detail, the common background provided by this legislative aim makes it a worthwhile endeavour to analyse both models for further features, whether common to both or not, that could be of interest to other fields.

${ }^{1}$ Directive 98/71/EC of the European Parliament and of the Council of 13 October 1998 on the legal protection of designs, OJ L 289, 28.10.1998, pp. 28-35 and Council Regulation (EC) No 6/2002 of 12 December 2001 on Community designs, OJ L 3, 5.1.2002, pp.1-24. For details, see below, 2.1.

2 Directive 96/9/EC of the European Parliament and of the Council of 11 March 1996 on the legal protection of databases, OJ L 77, 27.3.1996, pp. 20-28. For details, see below, 2.2. 
The paper will proceed in the following manner. After a brief survey of the salient features of European legislation governing industrial design and database protection, similar models combining traditional IP protection with a 'lower tier' of previously largely unregulated subject matter, or other regulatory models showing similar features as those found in design or database legislation will be outlined and examined as to whether they may have a place in (future) trade mark, copyright or patent law. Following that, the question will be posed as to whether there are more 'rights in the waiting', that is to say, interests which are only loosely regulated today, but which might be brought, by way of harmonisation, under the umbrella of intellectual property or sui generis regimes.

\section{Industrial Designs and Databases under European Legislation}

\section{Industrial Designs}

Before the European harmonisation of industrial design protection, Member States responded in different ways to the obligation to grant some form of legal protection to the appearance of commodities. ${ }^{3}$ The different approaches to protection were often described as following a patent or a copyright paradigm: the former is characterised by a strict novelty requirement and a monopoly type of protection (protection with barring effect), ${ }^{4}$ whereas the latter approach emphasises originality over novelty and only grants protection against copying. ${ }^{5}$ Apart from this difference, however, practically all national industrial design protection regimes coincided in so far as industrial designs had to be registered in order to claim protection. UK law was the only exception to that rule, with protection also being granted to unregistered designs under the condition that these are not 'commonplace'. ${ }^{6}$

3 That general obligation is already enshrined in Art. 5 quinquies of the Paris Convention ("Industrial designs shall be protected in all the countries of the Union"), without further details being given. A more specific regulation of the requirements and scope of protection, including its duration and potential limitations, is found in Art. 25 and 26 of the TRIPS Agreement. For a brief account of international design protection under the TRIPS Agreement, see e.g. Dinwoodie/Janis, Trade Dress and Design Law (2010), p.16.

${ }^{4}$ One typical example could be found in the law of the Nordic countries prior to harmonisation. See Levin, Die Zukunft des Designschutzes in Europa aus der Sicht des Rechts der nordischen Staaten, GRUR Int. 1998, 371.

5 The 'purest' example of a copyright approach to design protection was found in French law; see Ruijsenaars, Die Zukunft des Designschutzes in Europa aus der Sicht des französischen und des Benelux-Rechts, GRUR Int. 1998, 378.

${ }^{6}$ Regulated in Pt. III of the Copyright, Designs and Patents Act (CDPA) 1988. 
Except in the UK, claims against competitors emulating the appearance of unregistered commercially attractive product designs could only be based on forms of protection other than industrial design law. In France, a basis for protection in such cases is regularly found in copyright, as the threshold for protection is rather low. ${ }^{7}$ In Germany, on the other hand, where an elevated threshold applies to works of applied art, ${ }^{8}$ courts could only respond to the demand for protection in such cases by applying the rules against unfair competition. Hence, in Germany, but also even in France and in most other EU Member States, protection of product appearances, figured (and still figures) as a regular theme in Member States' case law dealing with 'slavish imitation' or 'avoidable origin deception', etc.

When European design legislation was harmonised so as to merge the patent and copyright approaches into a common 'design approach', a need to tackle the issue of protection for unregistered product appearances was also felt. Neither copyright nor unfair competition law were expected to offer a promising framework for this task. For copyright, harmonisation would have meant establishing a common threshold for protection of works of applied art, which is hardly feasible given the wide discrepancies between Member States' deeprooted attitudes and traditions in the field. Much the same is true for protection against imitation under unfair competition law - any attempt to institute notions on the European agenda for harmonizing unfair marketing practices such as slavish imitation would probably have met with adamant resistance, in particular from common law jurisdictions. In this situation, dealing with the issue within the framework of harmonised industrial design protection appeared to provide a smooth and easy way out of the dilemma.

As was the case for European trade mark law, harmonisation of industrial design legislation proceeded on two levels. National law was harmonised on the basis of the European design directive (71/98/EC, DDir) ${ }^{10}$ and in addition, a unitary system for industrial design protection was created by the Community Design Regulation (6/2002; CDR). ${ }^{11}$ Only the latter is of interest here, ${ }^{12}$ as it provides for protection in two forms: registered design rights may be obtained by filing an application with OHIM in Alicante. In addition, an Unreg-

${ }^{7}$ For a comparative analysis of German and French Law in that regard see Zech, Der Schutz von Werken der angewandten Kunst im Urheberrecht Frankreichs und Deutschlands (1999), with ample references to French case law at pp. 71 et seq.

8 The leading case in Germany is: BGH GRUR 1995, $581=28$ IIC 140 (1997) - Silberdistel.

${ }^{9}$ For an explanation of the 'design approach' see Kur, The Design Approach - What's Wrong With it?, [1993] EIPR 374 et seq.

10 Supra, note 1.

11 Supra, note 1.

12 For a comprehensive account of the Community Design Regulation, see Musker, Community Design Law: Principles and Practice (2002). 
istered Community Design (UCD) is obtained automatically as soon as the design is made available to the public in the territory of the European Community (Art. 11, 110a CDR). The prerequisites for protection - novelty and individual character - are the same for both types of rights. Also the scope of protection is basically the same for both; however, whereas protection based on registration can be invoked against any younger design falling into the scope of the prior design, the owner of a UCD needs to establish that the younger design has been copied, meaning that it was not created independently. Apart from that, the most prominent distinction between registered designs and UCDs concerns their duration: while registered designs are protected for five years, with prolongation of protection possible for up to a maximum of 25 years, unregistered designs are only protected for three years from the time of first publication in the EU.

\section{Databases}

Like in the field of industrial designs, the situation in Europe prior to harmonisation of database protection was characterised by much uncertainty. Although no doubt existed that collections of works, for instance in an anthology, were eligible for copyright protection as such, ${ }^{13}$ the situation for compilations of data was more doubtful. ${ }^{14}$ The extent to which copyright protection was granted for such collections varied widely, depending on the required standards of originality in the national systems. As a matter of principle, no copyright protection was granted to compilations which were the fruit of investment in time, money and organisational skills ("sweat of the brow") rather than resulting from creative efforts in their structure and arrangement. ${ }^{15}$ In the Nordic countries, the protection gap in this area was closed by granting, within the copyright act, sui generis protection for data compilations in the form of the so-called catalogue rule. In the United Kingdom, contrary to the general trend, even ordinary copyright protection could be obtained in these cases. Most other countries like Germany - were only prepared to consider such cases under the auspices of unfair competition. ${ }^{16}$ Concerning the options for harmonisation, lowering the

13 See Art. 2 (5) Berne Convention ("Collections of literary or artistic works ...”).

14 This was changed on the international level by Art. 10 (2) TRIPS, according to which "compilations of data or other material ... must be protected as such". See also Art. 5 WCT.

15 Most conspicuously, the issue was brought to the fore in US law in Feist Publications, Inc. v. Rural Telephone Service Co., 499 US 340 (1991).

16 The legal situation in European countries before and after the transposition of the database directive is reported by Davison, The legal protection of Databases (2008), pp. 103 et seq. For a brief account of the background to the database directive see also DG Internal Market Services Working Paper "First evaluation of directive 96/9/EC on the legal protection of databases", 12 December 2005, p. 8 note 9 (available at http://ec.europa.eu/internal_market/ copyright/docs/databases/evaluation_report_en.pdf). 
threshold for copyright protection for data compilations was found again to be no feasible way to approach the issue. Unfair competition as well was unfit as a basis for regulation, not only for the reasons set out above, but also because unlike an IP right, an unfair competition-type of protection would not have provided an option for the licensing and transfer of rights. As databases were expected to become highly valuable assets in the information society, any measure which might hamper their efficient economic exploitation appeared to be unsuitable.

As a result, protection for databases was regulated in Directive $9 / 96 / \mathrm{EC}^{17}$ in a two-tiered fashion. Copyright applies pursuant to chapter II of the directive if, and to the extent that, the database constitutes an author's own intellectual creation. In addition, Article 7 introduces a sui generis right for makers of databases to prevent the extraction and/or re-utilization of the contents of the database, provided that there has been a substantial investment in obtaining, verification or presentation of those contents. While copyright protects the creative achievement reflected in the arrangement and structure of the database, the sui generis right on the other hand tends to protect the data contained in the database as such. The protection provided by the sui generis right lasts for 15 years after the completion of the database and/or making it available to the public, and the period of protection recommences when substantial changes which require relevant investments have been made. Copyright protection, of course, lastss much longer (70 years after the death of the author).

\section{Evaluation}

The solutions to problems caused by atypical demands for protection found in the design and database directives have met with mixed reactions. The database directive was heavily criticised for going too far towards protecting pure information. ${ }^{18}$ Moreover, in an evaluation of the economic effects of the database directive carried out on the European Commission's behalf, no evidence was found that the sui generis right did achieve its main goal to foster investment into developing more and better databases, thereby boosting the position of the European Union on the global information market. ${ }^{19}$ In spite of this, however, it is generally acknowledged that even if database legislation is suboptimal conceptually as well as in many of its details, it has at least helped to straighten

\footnotetext{
17 Supra, note 2.

18 See for instance Westkamp, Protecting Databases Under US and European Law - Methodical Approaches to the Protection of Investments Between Unfair Competition and Intellectual Property Concepts, 34 IIC 772, 778 et seq. (2003).

19 See "First evaluation of directive 96/9/EC on the legal protection of databases" (supra, note 16), in particular pp. 24, 25.
} 
out the previous uncertainties resulting from legal divergences in the Member States. ${ }^{20}$

Harmonisation of design legislation, including the introduction of the UCD, has not given rise to similar controversies. One reason may be that its impact in practice remains rather unclear; reports on national case law concerning the UCD are still relatively scarce. ${ }^{21}$ Nevertheless, contrary to what might have been expected, the availability of protection under the UCD did not lead to a substantial decrease in claims based on unfair competition or copyright law. In particular, the notion that protection for unregistered product appearances should terminate after three years from first marketing does not seem to have become a bright line standard meticulously observed in legal practice. Protection after the lapse of the UCD is still in demand, and courts do not seem to be particularly hesitant to grant it. ${ }^{22}$ If the aim of introducing the UCD was to achieve an overall harmonisation of protection for product appearances, it must therefore be conceded that this goal has only been achieved imperfectly.

\section{How Would Two-Tier Protection Work in Other Fields?}

\section{Two-Tier Protection in Trade Mark Law}

In looking for ways to apply the two-tier model to trade mark law, an argument could be made that such a scheme is already present, in the form of protection against unfair advantage being taken, or detriment done to, the reputation or distinctive character of trade marks having a reputation on the national or Community level. It is indeed true that before harmonisation, this kind of extended protection was rarely granted within the framework of trade mark laws, ${ }^{23}$ but rather formed part of unfair competition or general tort law. Nevertheless, it would be difficult to conceive of protection for trade marks which have such a reputation as a 'lower tier' in comparison to trade mark law in its traditional form: other than in the case of UCDs and non-original databases, protection is

20 That point is also acknowledged in the MPI's statement to the First Evaluation of Directive 96/9/EC on the Legal Protection of Databases, 37 IIC 551 (2006).

${ }^{21}$ For an account of German practice, see Gottschalk/Gottschalk, Das nichteingetragene Gemeinschaftsgeschacksmuster: Eine Wunderwaffe des Designschutzes?, GRUR Int. 2006, 461.

22 As an example, see: BGH GRUR 2006, $79=38$ IIC 128 (2007) - Jeans I.

${ }^{23}$ However, in the Nordic countries, extended protection was available in the framework of trade mark legislation, under the so-called Kodak rule. See Kur, Das neue dänische Markengesetz als Beispiel für die Umsetzung der EG-Markenrechtsrichtlinie, GRUR Int. 1991, 785, 787, with references to Danish case law. 
stronger than under the regular scheme of protection rather than being reduced in scope or time.

Clearer similarities with the models discussed above - in particular with European legislation relating to industrial designs - would be found if protection under the umbrella of trade mark law were extended to unregistered marks, and possibly also to other business identifiers. ${ }^{24}$ It can hardly be doubted that a demand exists for such extended harmonisation. Until now, the relevant provisions in the Member States have differed widely from each other, ranging from regimes granting protection on the basis of mere $\mathrm{use}^{25}$ to others strictly adhering to a registration requirement ${ }^{26}$, with some intermediate forms in-between ${ }^{27}$. The broad variance between national regimes is a problem not least considering the interaction between national rights and the Community trade mark: proprietors of national rights from countries granting protection for unregistered signs in a generous manner are more likely to prevail over a Community Trade Mark than those using a sign in countries where a more rigid regime applies. Strictly speaking, lack of harmonisation in this respect might even result in the distortion of competition within the internal market.

It could be argued that a legal basis for implementing at least a minimum degree of harmonisation in this regard is provided in any case by Article 6bis of the Paris Convention, which compels Member States to protect unregistered marks against registration or use by third parties in the event that the mark is wellknown in the country where protection is sought. It can indeed be submitted that protection for well-known marks already forms part of all EU Member States' current trade mark laws, due to the obligations under the Paris Convention, which are reinforced by Article 16 (2) of TRIPS. ${ }^{28}$ Also on the Community

${ }^{24}$ Another possible project for future harmonisation - not to be commented on any further here- could be the integration of so-called 'non trade mark use' (use of a sign for other purposes than to distinguish goods or services) in trade mark law, which is presently addressed in Art. 5 (5) of the Trade Mark Directive (95/2008/EC).

${ }^{25}$ For instance in Denmark, and to some extent also in Italy; see references in Kur, Harmonisation of the Trademark Laws in Europe - An Overview, 28 IIC 1, 9 (1997), notes 40 and 45. An extensive overview on the protection of unregistered trade marks and other business identifiers in the EU member states (before 2004) is given in Schricker/Bastian/Knaak (eds.), Gemeinschaftsmarke und Recht der Mitgliedsstaaten (2006).

${ }^{26}$ For instance in France. However, even where trade mark law in principle excludes protection for unregistered marks, an exception must be made for signs claiming protection under 6 bis of the Paris Convention (see below).

27 This concerns for instance Germany, Sweden and Finland, where protection is granted for unregistered marks that are recognised by the relevant trade circles as indicating the goods or services of a particular enterprise (Verkehrsgeltung; inarbetning); Kur, 28 IIC 1, 9 (1997) with references in notes 41,42 and 43.

${ }^{28}$ In addition to the obligations outlined in Art. 6bis of the Paris Convention, Art. 16 (2) of TRIPS provides that protection must also be granted to service marks, and that it suffices for a mark to be regarded as well-known if knowledge in the relevant sector of the public has been achieved by way of advertising, i.e. without the mark being actually used in the market 
level, protection for unregistered, well-known marks has been provided for to some extent. Pursuant to Article 8 (2) (c) CTMR, marks which are well-known in a Member State at the date of application or priority are regarded as prior rights in opposition or cancellation proceedings. Due to the fact that both the directive and the CTMR only apply to registered marks, none of them contains a legal basis for protection of well-known, unregistered trade marks against infringing use of the same or a similar sign. Nevertheless, all national trade mark laws include such provisions, as a tribute to Member States' obligations under the Paris Convention and TRIPS. On the Community level, however, no such provisions are found. Consequently, the proprietor of an unregistered mark which is well-known in the Community can only pursue the claim on a country by country basis; there is no access to the jurisdiction system established for CTM infringements. This constitutes a deficiency which arguably might raise doubts as to whether the EU completely lives up to the duties incurred under the TRIPS Agreement. ${ }^{29}$

Misgivings resulting from the lack of protection on the Community level could be overcome by an express implementation of Article 6bis of the Paris Convention (and Article 16.2 of TRIPS) in the CTMR. Such a step would also create another species of unregistered Community right, aside from the UCD. Furthermore, theoretically, harmonisation of unregistered marks might go even further than this by also recognizing signs as worthy of protection which do not reach the level of being well-known, yet which have attained, through use in trade, a certain level of awareness among interested circles ("Verkehrsgeltung" in German). A legal basis for such a step could be found in the argument that registration of the same or a similar mark by an unrelated third party often creates a likelihood of confusion among those who have become accustomed to associating the sign with the first user. Accordingly, granting protection to the first user against the usurpation of such signs by others would also serve the public interest. Moreover, it could even be interpreted as a timely move towards the pro-active implementation of the objectives underlying Article 6 (2) (a) of the Unfair Commercial Practices directive (29/2005/EC). ${ }^{30}$ However, although that

in the country concerned. Art. 16 (3) TRIPS extends the protection for well-known marks to use for dissimilar goods, if a connection is suggested thereby and provided that the legitimate interests of the proprietor are damaged. However, the provision only refers to marks which are "registered" and therefore does not make it mandatory to grant such protection also to unregistered trade marks.

29 The EU is not a member of the Paris Convention and therefore it is not bound by it directly. However, the EU has signed up to the TRIPS Agreement, which obliges its members to comply with the Paris Convention in its latest version. In addition, the EU is directly bound by TRIPS to comply with Art.16.2 (and 16.3) of the Agreement.

30 Directive 2005/29/EC of the European Parliament and of the Council of 11 May 2005 concerning unfair business-to-consumer commercial practices in the internal market and amending Council Directive 84/450/EEC, Directives 97/7/EC, 98/27/EC and 2002/65/EC of 
type of protection exists already in a sizeable number of Member States, by explicitly protecting unregistered marks on the basis of market recognition or in the form of "passing off", the diversities between the national attitudes towards protection of unregistered marks are still so large that any form of harmonisation appears unlikely in the near future.

\section{Two-Tier Protection in Copyright}

The model presented by the database directive - traditional copyright protection being combined with a 'lower tier' of protection for investment into making informational or creative content available - basically complies with the structure commonly found in copyright law where it addresses producers' rights (and rights of performing artists) in their capacity as rights which are 'neighbouring' or 'related to' the protection available for literary and artistic works. In this regard, the database directive is not novel or unique, but had its forerunners in other areas of copyright, where similar concerns have led to codification. For instance, protection for producers of phonograms was originally granted in Germany only on the basis of unfair competition law, before it was incorporated into the copyright act as a type of related right. ${ }^{31}$ Similar discussions are still on-going: in recent times, the question of whether publishers should be accorded their own producer's right, instead of having to rely on their contractual relationship with the authors, has been repeatedly aired ${ }^{32}$.

Aside from the commonly employed forms of two-tier protection in copyright, another model of two-layered protection might likewise take inspiration from the database directive. In essence, it would mean that claims for protection of largely utilitarian works, or works of only minimal artistic character, are dismissed from the core area of copyright, and are instead submitted to a

the European Parliament and of the Council and Regulation (EC) No 2006/2004 of the European Parliament and of the Council, OJ L 149, 11.6.2005, pp. 22-39. According to Art. 5 (2) (a), "(A) commercial practice shall also be regarded as misleading if, in its factual context, taking account of all its features and circumstances, it causes or is likely to cause the average consumer to take a transactional decision that he would not have taken otherwise, and it involves: (a) any marketing of a product, including comparative advertising, which creates confusion with any products, trade marks, trade names or other distinguishing marks of a competitor".

31 Protection for phonogram producers and performing artists was only codified, as in Sec. 85 of the Copyright Act of 1965. Before that, performers were granted a fictitious 'adaptation right' on the basis of the general clause of the Unfair Competition Act. Producers were protected on the basis of a licence in that right, see e.g. BGH GRUR 1960, 614 - Figaros Hochzeit.

32 For instance in Germany, strong demands for the creation of a specific 'publishers' right' was put forward by several major publishers in the so-called "Hamburger Erklärung" (Hamburg manifesto) with some political success: after the general elections of September 2009 , the publishers' right was included as a legislative project in the agenda of the governing coalition between Christian and Liberal Democrats. 
body of sui generis rules. These rules could be tailored to the specific character of such subject matter in a more appropriate way than could be done by copyright law, whose strong accent on moral rights and the author's personality, as well as its long duration, are regularly disproportionate responses to such modest creative or intellectual activities. For instance, not only would works of applied art whose appearance is dominated by their functional purpose (and which, in many countries, belong within the ambit of industrial design legislation) be banned from copyright protection under such an approach, but also press articles (news reports) and other minor types of literary works, ring tones and jingles, and - last but not least - computer programs. The consequence of separating such items from the scope of copyright law proper would be that their protection would not be subject to the obligations concerning copyright works under the Berne Convention, so that duration of protection could be much shorter, limitations could be imposed more freely, and, where appropriate, an obligation to register could even be introduced as a prerequisite for claiming protection ${ }^{33}$.

However, past experiences - most notably in the area of computer programs - have shown that European legislation has tended to develop in rather the opposite direction. When the best mode of protection for software was discussed in the 1980s, freedom from constraints under the Berne Convention was not considered to be an advantage. On the contrary, instead of settling for sui generis protection, the software directive (91/250/EEC) deliberately brought computer program protection under the umbrella of copyright, precisely in order to make sure the Berne Convention applied, and thus to ensure the applicability of a groundwork of international protection for such items. The route taken by European legislation was also reinforced on the international level: in the TRIPS Agreement as well as the World Copyright Treaty (WCT), computer programs were expressly recognized as belonging in the category of literary works. ${ }^{34}$ Having been turned into an international standard to which (in case of TRIPS) more than 170 countries are bound, the path to revision of what with

33 Whether it could also be claimed, as with suigeneris databases protection, that the basic principle of national treatment does not apply vis-à-vis other Member States of the Berne and Paris Conventions and the TRIPS Agreements, appears at least doubtful. No such exemption from the national treatment principle can be assumed to exist for works applied art, if they are "downgraded" to protection under industrial design law. Even in that form, they would fall under the Paris Convention and TRIPS. Regarding the other potential items for sui generis protection, the answer would depend on whether this is ultimately a form of unfair competition protection which implements Art. 10bis of the Paris Convention. At the very least, nationals of other Paris Union members could not be precluded from unfair competition protection granting a similar type of protection as that enshrined in the sui generis right, even if resort to unfair competition law were generally excluded for those who are entitled to the benefits of sui generis legislation.

34 Article 10 (1) TRIPS; Art. 4 WCT. 
hindsight may be considered as a historic mistake is practically barred. At the very least, any attempt to replace copyright protection with a sui generis right with regard to computer programs would have to confront a plethora of legal and political problems.

This does not render it impossible, however, to venture a rollback from copyright to sui generis rights in other areas, such as the proverbial 'small coin' of copyright. As the Berne Convention does not establish a particular threshold to be observed by national legislatures, such an approach would be compatible with international obligations. It must also be conceded, however, that the prospect of such initiatives being taken is very small. Although it concerns a different area, the recent plans by the Commission to prolong the protection granted to performing artists and phonogram producers to 95 instead of, the present, 50 years, ${ }^{35}$ may indicate a reversal of the trend: tendencies towards strengthening copyright-related subject matter are still vibrant, and the differences between the 'upper' and 'lower' tiers - between copyright and producers (or other investors') rights - tends to be erased instead of being more clearly delineated.

Finally, another aspect of the two tier model shall be considered briefly, namely that the UCD could be a forerunner of (more) unregistered rights to appear on the Community level. Like the prospect of an unregistered Community trade mark addressed above, copyright might be another candidate for such a solution. What may have sounded utopian some years ago has been repeatedly ventilated in Commission papers as a possibility to be further investigated. ${ }^{36}$ The reason lies in the fact that a unitary copyright covering the entire Community would be better suited to the largely globalised market structure in the information and entertainment industries than the present fragmented national rights. It is also possible to argue that creating a unitary title in copyright would not be an overly ambitious step in those areas where copyright is actually fully harmonised. The fact remains, however, that harmonisation has not been achieved, and the national systems are still quite different in certain core areas of copyright such as the notion of a work, ${ }^{37}$ moral rights, exceptions

35 Proposal for a European Parliament and Council Directive amending Directive 2006/116/EC of the European Parliament and of the Council on the term of protection of copyright and related rights $\{\mathrm{SEC}(2008) 2287\}\{\mathrm{SEC}(2008) 2288\}$. The proposal was evaluated very critically by the academic community, see e.g. statement by the Max Planck Institute, available at http://www.ip.mpg.de/en/data/pdf/stellungnahme-bmj-2008-09-10def_eng.pdf.

${ }^{36}$ In "Creative Content in a European Digital Single Market: Challenges for the Future", Reflection paper by DG INFSO and DG MARKT, 22 October 2009, p. 18; Green Paper on the online distribution of audiovisual works in the European Union COM (2011) 427 final, p. 13.

37 A question mark needs to be added here after the CJ EU's decision C-5/08 - Infopaq v. Danske dagbalders Forening. The Court of Justice held (para. 37) that copyright within the meaning of Art. 2(a) of Directive 2001/29 is liable to apply only in relation to a subject-matter which is original in the sense that it is its author's own intellectual creation. This line might be 
and limitations. As there is hardly even any realistic expectation that a common or even unanimous approach could be found towards those sensitive issues, ${ }^{38} \mathrm{a}$ Community copyright, if it came into existence at all, would probably only take a very rudimentary form and would still leave much scope for deference to national law and its diversities. ${ }^{39}$

\section{Options for Two-tier Protection in Patent Law}

In patent law, a combination of full protection in the traditional form and protection on a lower tier could basically be conceived of in two different forms. First, one might think of devising an integrated system of patent and utility model protection. Second, it could be considered whether patent protection should be complemented by harmonised rules on protection for undisclosed information ('know how'). Both alternatives shall be addressed in turn.

In contrast to industrial designs, utility models are not universally acknowledged as a species of intellectual property which all countries must protect in one way or another ${ }^{40}$. Nevertheless, utility model protection is firmly grounded in a number of legal systems, where it forms part of the larger category of rights protecting technical innovation. In Germany, protection for utility models dates back to $1891 .{ }^{41}$ Having first been designed so as to relate only to the functional shape of products ('Raumform'), ${ }^{42}$ protection later-on developed into a kind of 'petty patent', with very similar features to patent law itself ${ }^{43}$ yet with

interpreted as imposing a common threshold for assessing originality, and thereby the essential prerequisite for protection as a 'work', under European copyright law.

${ }^{38}$ See, however, the proposal for a European copyright code recently made by the socalled Wittem group (Wittem project; text and explanation available at http://www.copy rightcode.eu/.).

39 On the other hand, if it should be possible against all odds to agree on a comprehensive copyright code like the one proposed by the Wittem group (previous footnote), it would not seem to make much sense if national copyright remained in place as a complement to Community copyright law. Rather than coexist with national copyright, the Community system would most likely replace it in its entirety.

40 Although the Paris Convention mentions utility models in several of its provisions, there is no rule corresponding to Art. 5 quinquies (supra, note 3), by which protection of utility models would be declared to be mandatory.

${ }^{41}$ German legislation on utility models was the first in Europe, and has become the template for similar laws, in particular in the Nordic countries, see Björkwall, Nyttighetsmodeller: Ett andamålsenlig innovationsskydd? (2009), pp. 31 et seq.

42 The so-called 'Raumformerfordernis' derived from the fact that originally, the protection was meant for industrial designs which were too 'technical' to be protected under industrial design law, which was geared more towards the protection of aesthetic creations. See e.g. Asendorf, Herkunft und Entwicklung des "Raumformerfordernisses" im Gebrauchsmusterrecht, GRUR Int. 1988, 83.

${ }^{43}$ The most conspicuous difference regarding subject matter concerns process patents, which remain expressly excluded from utility model protection ( $\mathbb{2} \mathrm{Nr} .3$ of the German Act). 
the threshold being lower and the duration of protection shorter. Similar legislation can be found in several European countries, although others have deliberately abstained from providing such protection. In addition to doubts concerning the need to create a specific regime for the protection of small inventions, a risk was also perceived that granting protection on a lower tier might result in the 'watering down' of protection for innovation under the patent regime. In spite of this concern, attempts were made in the late 1990s to promulgate a European directive on utility models, so as to provide for harmonised protection in all Member States. ${ }^{44}$ After experiencing strong opposition from interested parties in some countries, however, the proposal was removed from the political agenda in 2005. Unless a strong case, based on new arguments, can be made for harmonizing protection of utility models, it is unlikely that the previous attempts will be renewed any time soon.

The protection of undisclosed information is an altogether different matter. The need for such protection is beyond doubt, which is reflected in the fact that it has become part of the obligations imposed under TRIPS. ${ }^{45}$ As to the means of protection presently applying, most countries have enacted specific provisions which may be found in IP legislation, specific legal acts, or within unfair competition provisions. Criminal law also plays a strong role, in particular where breach of secrecy takes the form of large-scale commercial espionage. Furthermore, close links exist with contract law and labour law, as firms that feel vulnerable in this regard have a strong interest in binding their employees to pledges of secrecy and non-exploitation, even after termination of the employment contract. Finally, tying agreements concluded for the same purpose will typically call for scrutiny under competition (antitrust) law, as yet another legal field involved in the patchwork of different laws to be considered.

The fact that legal protection of undisclosed information needs to be considered from so many different angles renders it a rather unlikely candidate for expedient European harmonisation, not least because comprehensive regulation would touch upon the areas of competence of several different units within the European Commission. Although the practical demand for harmonised protection may be more pronounced than is the case with utility models, no relevant initiatives have been undertaken to date. Another reason possibly dampening the legislative impetus might be the fact that the most urgent harmonisation project in the area of rights protecting technical innovations - the Community patent - is still an unfinished item on the current agenda. In this situation, it is unlikely that the many intricacies involved in bringing national rules on secret

${ }^{44}$ (Amended) proposal for a European Parliament and Council Directive approximating the legal arrangements for the protection of inventions by utility model, COM/99/0309 final - COD 97/0356.

45 Art. 39 TRIPS. 
know-how and other types of undisclosed information into a harmonised form will be tackled.

\section{Further Reification of Rules on (Un)Fair Conduct? (Sports Rights as an Example)}

While UCD protection as well as suigeneris protection for databases were considered above as the 'lower tier' in comparison to traditional design and copyright protection, both types of protection may also be viewed as forming the 'upper tier' in comparison to the amorphous body of unfair competition rules from which they have emerged. From that perspective, the aspect common to both cases is the fact that unregistered designs and unoriginal databases have been elevated above the level of mere rules of conduct, having grown into a kind of property right in the process.

Possible candidates for such a metamorphosis can be found in various areas. Most obviously, the organizers of sporting events claim a right to any form of more than de minimis exploitation of the public interest in such activities. ${ }^{46} \mathrm{The}$ most important and debated facet of such a right would cover conduct usually referred to as 'ambush marketing': marketing measures of a different kind by which parties position themselves within the environs of major tournaments and other sporting events, thereby attempting to benefit from the public awareness and attraction caused by the occasion, without paying to become an official sponsor. In order to avoid any legal problems, organizations with high leveraging power such as the Olympic Committee or the World Soccer Association regularly try to exert pressure on host countries to ensure that they enjoy full market exclusivity, if necessary, by changing domestic legislation. ${ }^{47}$ However, on the lower level of everyday sporting events with little or no commercial impact, activities by third parties may also become the target of objections by sports organizers. An example is found in the recent German case "Hartplatzhelden", where a regional association of soccer clubs sought an injunction prohibiting the display of private video clips from amateur soccer games on a non-

${ }^{46}$ For a detailed account, see e.g. Penkert, Güterzuordnung als Rechtsprinzip (2008), pp. 143 et seq.

47 See e g the London Olympic Games and Paralympic Act (30 March 2006). Inter alia, it introduces a new type of right, the "London Association Right" (LOAR), which is designed to prevent the use of certain representations in the course of trade to create an unauthorized association with the Games. According to the London Organizing Committee of the Olympic Games (LOGOC), the right shall allow to enjoin persons from being able "to gain for free benefits which LOGOC's sponsors, official suppliers and merchandise licensees will invest millions of pounds in the Games to obtain", and which would ordinarily not infringe intellectual property rights. 
commercial website. ${ }^{48}$ The court of first instance reasoned, with approval from the court of appeals, that showing the video clips without permission from the association was simply an act of unfair competition. However, most commentators agreed that what the courts actually did in this case amounted to the (implicit) grant of a property right rather than merely prohibiting unfair conduct. The Federal Court of Justice reversed the case, thereby stopping a trend which otherwise might have indicated the birth of a new type of sui generis right praeter legem. ${ }^{49} \mathrm{Had}$ it been confirmed by the Federal Court of Justice, that right might have arguably extended also to displays of footage taken from public events, such as street bicycle races, or city marathons etc. From the perspective of the organizers of such activities, a loophole would have been closed thereby, because under the present legal position, they can only rely on the right to authorize filming or other recordings within their premises on the basis of their domestic authority ("Hausrecht"), that is, only within the closed areas to which they can grant conditioned access.

This is not the place to speculate about the woes or wisdom of granting sui generis rights for sports events, or for any other subject matter possibly forming a property right in nascendo. Only some general remarks shall be made here. First, it is frequently assumed that granting an exclusive right will automatically lead to increased investment in the sector concerned. However, that assumption needs to be critically reviewed, not least in the light of the experience of the database directive. Having compared developments in the European Union after the creation of the sui generis right, and in the USA, where no such right exists, the European Commission in its evaluation report on the database directive came to the conclusion that the sector fared slightly better in the USA. ${ }^{50}$ Second, it could be argued that it is possible also to clearly outline the limitations of such rights, in particular vis-à-vis the public interest in information and entertainment, only by explicit regulation. It is indeed true that legal developments may spin out of control, in particular when novel demands for protection are voiced by strong and well-organized protagonists, such as exist in the field of sports rights. However, the argument that in order to impose appropriate limitations, a property right must first be granted appears somewhat twisted: if the principle that freedom of competition is given prevalence over individual protection interests where and as long as no property right is attributed to potential owners were taken seriously, the lack of explicit limitations would not have to be perceived as a portentous threat to the public domain. Finally, considering the situation in Europe, further arguments may be derived from the fact that the flourishing of diverse national rules and practices

${ }^{48}$ OLG Stuttgart, MMR 2009, 395 - hartplatzhelden.de; see Obly, Hartplatzhelden.de oder: Wohin mit dem unmittelbaren Leistungsschutz?, GRUR 2010, 487.

49 BGH, judgment of 28 October 2010, case no. I ZR 60/09.

50 First evaluation of directive 96/9/EC (supra, note 16), at p. 24. 
that typically results from the quest for novel forms of protection is likely to create practical problems for those engaging in cross-border business. Indeed, as was said above with regard to database protection, harmonisation is sometimes preferable, even in spite of certain flaws, to a status quo characterized by fragmented national protection schemes. However, this does not necessarily mean that those rules must take the form of "property", i.e. of exclusive rights. Instead it might suffice to promulgate harmonised specific rules of conduct, which until now have been missing from the law applying to business to business (B2B) competition..$^{51}$ If that is considered to be unfeasible or unsatisfactory, a system based on liability rules could be envisaged, whereby access is conditioned by certain requirements, such as typically (although not necessarily) payment of fair remuneration. ${ }^{52}$ Also here, the database directive, or rather its history, provide an example: the first proposal for the directive had included a non-voluntary license for access to and use of sole-source databases. As is well known, the provision was deleted in the course of negotiations, with an enhancement of the requirements for protection being accepted as a functional replacement for the change..$^{53}$ But although it was not adopted in the end, the fact that a regime change towards a (partial) liability rule was proposed and discussed in the framework of the database directive may at least serve as an indication that the general pattern of reification can and should be departed from, where that is feasible and appropriate.

\section{Final remarks}

In spite of its somewhat vague contours, the model of two tier protection as in European industrial design and database legislation provides an interesting approach to present and future harmonisation projects. The most general lesson it offers is that it is possible to offer distinct modes of protection in the same field, covering the same or closely similar subject matter, thereby enlarging the spectrum of legal options and effects. The model also demonstrates that there are forms of protection in-between, on the one hand, full-fledged, long-term property rights and, on the other hand, unspecified rules of conduct. If designed and applied properly, such in-between solutions are not only capable of enhancing

51 As to the structural difference between such delict-based rules and exclusive property rights see in particular Peukert (supra, note 46), pp. 865 et seq.

52 The distinction between property rules and liability rules goes back to the article by Calabresi/Melamed, Property Rules, Liability Rules, and Inalienability: One View of the Cathedral, 85 Harvard Law Review, 1089 (1972).

53 On the history of the database directive, including the proposal for an unvoluntary license, see Davison (supra, note 16), pp. 50 et seq.; Leistner, Datenbankenschutz im deutschen und europäischen Recht (2000), pp. 30 et seq. 
legal security, but they might also encompass the interests of all stakeholders as well as those of the public in a more flexible, balanced way than what is possible under traditional intellectual property regimes.

However, the caveat needs to be made that like in all areas of intellectual property, two tier protection tends inevitably to lead to an enhancement of the general protection level. Typically until to-date, harmonisation based on that model was marked by a reification of conduct rules, without other regulatory models having been put to the test in practice. This does not have to be continued. Rather than advancing straight to the proprietary level, two tier protection in Europe could also provide a field for experimentation with other forms of protection, such as specified B2B conduct rules, or mixed schemes including features of liability regimes. 



\title{
Common Principles of Secondary Liability?
}

\author{
Matthias Leistner
}

\section{Introduction}

The quest for common principles of secondary liability for the infringement of Intellectual Property Rights (IPRs) in Europe faces a double challenge. First, the question that has to be answered is whether there are common principles of secondary liability with regard to different kinds of IPRs. As a matter of course, the answer to this question as well as the availability and conditions of actions concerning joint and contributory liability, may differ in the laws of the different Member States. Therefore, secondly, the question has to be answered whether identifiable common principles of secondary liability exist in the different Member States' lawes. The answer to this second question is obviously influenced by the framework of secondary Community law in the field of intellectual property which, therefore, must also be taken into account.

Moreover, with regard to the fundamentals of contributory liability a further distinction must be made at the outset. Namely, that in many Member States' laws contributory liability is governed, on one hand, by the general principles of 'joint tortfeasance', 'procurement' or comparable heads of tortious liability and, on the other hand, certain statutory provisions concerning contributory patent infringement as well as provisions concerning contributory trade mark infringement (in some Member States), provide for specific rules on the liability of certain suppliers of technology and other indirect infringers. Thus, the establishment of secondary liability for the infringement of IPRs in general case law on tortious liability and the different kinds of specific statutory heads of 'upstream' liability which may be provided for by specific statutes governing the different kinds of IPRs must be distinguished.

The resulting matrix of the quest for common rules or principles of secondary liability is obviously very complex. It consists, first, of the necessary distinction between general principles of tortious liability for the infringement of IPRs and specific statutory provisions on liability for certain 'upstream' contributory acts; secondly, of the issue of whether the resulting principles are similar for the different kinds of IPRs; and, thirdly, of the question of whether certain common principles can be identified throughout Europe in that regard. Against this complex background and considering the Conference's limited time frame, fo- 
cus on the fundamental structures is needed in order to identify at least some preliminary structural guideposts for future research in the area. Consequently, I will limit the quest for common principles in Europe to the level of the basic structures of secondary community law (see infra II) and to a brief discussion of three instructive case examples from Member States' laws (see infra III). Namely, the basic rules and principles of secondary liability in Germany, the United Kingdom and France shall be analysed as their comparison is particularly rich in contrast. On the basis of this brief analysis, certain promising fields for future research and some fundamental policy alternatives for the future of secondary liability in European IP law shall be outlined (see infra IV).

\section{The Framework of European Law}

The framework of European law with regard to indirect liability for IPR infringement is still patchy. The Enforcement Directive 2004/48/EC ${ }^{1}$ as well as the Information Society Directive 2001/29/EC ${ }^{2}$, however, oblige the Member States to provide for certain claims against indirect infringers (see infra 1). By contrast, Art. 12 to 15 of the E-Commerce-Directive 2000/31/EC ${ }^{3}$ contain limitations on liability in the particularly important field of internet service providers (ISPs) (see infra 2). Finally, provisions on the protection of technological protection measures (TPMs) and Digital Rights Management information (DRM) in the Information Society Directive as well as some other provisions in area-specific copyright Directives can be characterised as regulating specific cases of indirect liability (see infra 3).

\section{Contributory Liability According to the Enforcement Directive and to the Information Society Directive}

Notwithstanding the limitations on ISP liability contained in the E-Commerce-Directive ${ }^{4}$, Art. 9 and 11 of the Enforcement Directive oblige Member States to provide for the possibility of injunctions, including interlocutory in-

${ }^{1}$ Directive 2004/48/EC of the European Parliament and of the Council of 29 April 2004 on the enforcement of intellectual property rights, Consolidated Version, OJ L 195/16 of 2 June 2004.

2 Directive 2001/29/EC of the European Parliament and of the Council of 22 May 2001 on the harmonisation of certain aspects of copyright and related rights in the information society, OJ L 167/10 of 22 June 2001.

3 Directive 2000/31/EC of the European Parliament and of the Council of 8 June 2000 on certain legal aspects of information society services, in particular electronic commerce, in the Internal Market, OJ L 178 of 17 July 2000.

${ }^{4}$ See Art. 2(3) Enforcement Directive: "This Directive shall not affect: (a) the Community provisions governing the substantive law on intellectual property, ..., and Art. 12 to 15 of Directive 2000/31/EC in particular". 
junctions, against 'intermediaries whose services are used by a third party to infringe an intellectual property right'. The respective provisions exclude the areas of copyright and related rights. In that regard they refer to the Information Society Directive. Art. 8(3) of the Information Society Directive, however, provides for an equal obligation of the Member States to ensure that rightholders are in a position to apply for an injunction against respective intermediaries. Thus, the only difference between both instruments is that the Information Society Directive does not explicitly provide for the possibility of interlocutory injunctions. This leaves the general principle unaffected: Member States have to provide for a possibility of seeking injunctive relief against intermediaries whose services are used by primary infringers (in particular, in the digital environment ${ }^{5}$ ). Therefore, provisionally, one might say that European secondary law does indeed include a minimum nucleus of secondary liability for the infringement of IPRs, i.e. the general possibility to apply for injunctions against certain intermediaries. At the outset, provisions have been made in this respect in European law applying equally to the different kinds of IPRs. Therefore this minimum standard, limited as it may be, can also be characterised as a general rule of secondary liability in European law.

However, the scope of the resulting obligation for the Member States is far from clear. Recital 59 of the Information Society Directive (on copyright and related rights) as well as Recital 23 of the Enforcement Directive (on industrial property rights) explicitly leave the conditions and modalities or procedures of such injunctions to the national law of the Member States. In particular, as mere minimum provisions, these obligations apply without prejudice to any other measures, procedures and remedies available. Therefore, the questions as to whether only injunctive relief should be provided for or whether (and which) other remedies should be applicable against secondary infringers are left to the national laws of the Member States. Consequently, inter alia, the crucial questions of whether and under which conditions a claim for damages can be directed against indirect infringers are not regulated by European law. Besides, European law does not provide for principles beyond the specific area of intermediaries. To make matters worse, the term 'intermediary' is not defined in the relevant Directives thus leaving the boundaries of the area of minimum harmonisation unclear. The principle of effective harmonisation would provide an argument for a wide definition in this regard, so as to include any person whose services are used for infringements by third parties.

Finally, the details of the relationship between the rules on the liability of intermediaries in the Enforcement and Information Society Directive and the 'safe harbour' rules of Art. 12 to $15 \mathrm{E}$-Commerce Directive for ISPs have not been specified on the level of European statutory law. Art. 2(3) of the Enforce-

\footnotetext{
${ }^{5}$ Cf. e.g. Recital 59, Information Society Directive.
} 
ment Directive only acknowledges that the Directive shall leave Art. 12 to 15 of the E-Commerce Directive unaffected. However, that leaves a crucial issue unsolved. Namely, how shall the provider privileges, according to Art. 12 to 15 E-Commerce Directive, be interpreted in light of the fact that the Enforcement Directive provides for the (obligatory) possibility of injunctions against intermediaries - inter alia in the digital environment - while Articles 12 to 15 of the E-Commerce Directive could be interpreted in such a way as to substantially undermine that provision for most practically relevant situations with regard to ISPs. Thus, the balance between these two provisions mainly depends on the (contentious) interpretation of the substantive rules of Art. 12 to $15 \mathrm{E}-\mathrm{Com}-$ merce Directive. This shall now be discussed.

\section{Limitations on the Liability of ISPs According to the E-Commerce-Directive}

Art. 12 to 15 of the E-Commerce Directive privilege different kinds of ISPs namely access and transmission providers (Art. 12), caching providers (Art. 13), and (most importantly) host providers (Art. 14) - with regard to liability for the transmitted, cached or hosted information, when the particular conditions of these provisions are fulfilled. Host providers' liability is excluded on the condition that the provider has no actual knowledge of the infringement and no awareness of any facts or circumstances from which the infringement is apparent; moreover, the provider, upon obtaining knowledge or awareness of the infringement, has to act expeditiously to remove or to disable access to the infringing information. However, the resulting privilege - like Art. 12 and 13 shall not affect the possibility of Member States' courts or administrative authorities to require the service provider to terminate or prevent an infringement according to national law ${ }^{6}$. At the same time, the general principle laid down in Art. 15 must always be taken into account: according to Art. 15 of the E-Commerce Directive, Member States must not impose any general obligation on ISPs to monitor stored or transmitted information.

As the resulting privilege for ISPs particularly - and most importantly - includes liability for the infringement of IPRs, the potential influence of these provisions on the practical application of injunctions against certain intermediaries, according to the Enforcement and Information Society Directive, is obvious. The potential field of overlap becomes even larger because of the recent trend in emerging European case law to define the range of services covered by the definition of service providers broadly ${ }^{7}$. Consequently, if the privi-

6 Cf. also Recital 45, E-Commerce Directive.

7 See Opinion of Advocate General Maduro in cases C-236/08, C-237/08 and C-238/08, Google France, paras. 128 et seq.; ECJ, Judgment of 23 March 2010, joined cases C-236/08 to 
lege were fully extended to cover injunctive relief, it would subject injunctions against intermediaries to certain conditions and - at least partly - undermine the effectiveness of possible claims for injunctions against intermediaries for the most economically important field of such applications, namely ISP liability. Formally, this legal situation would probably comply with the obligations of the Information Society and Enforcement Directive because these instruments leave the conditions and modalities of injunctions against intermediaries open, provided that such injunctions exist in principle. However, a substantive friction between the objectives of the Enforcement Directive and such an interpretation of the E-Commerce Directive with regard to the liability of internet intermediaries (or service providers) cannot be denied. In particular, the Enforcement Directive calls for effective means of enforcing IPRs ${ }^{8}$ and makes it clear that the possibility of injunctions against intermediaries is part of that general objective 9 . The Information Society Directive is even more clear on that point: given the fact that, particularly in the digital environment, the services of intermediaries are increasingly used by third parties for infringing activities, and that "in many cases such intermediaries are best placed to bring such infringing activities to an end", rightholders should have the possibility of applying for an injunction against intermediaries even when the acts of the intermediaries do not constitute primary copyright infringement ${ }^{10}$. The objective to ensure the effective protection of IPRs, particularly in situations where the intermediary is the cheapest cost-avoider, becomes utterly clear from these propositions.

At the same time, the E-Commerce Directive ${ }^{11}$ allows for an interpretation which does not fully apply the 'safe harbour' rules for ISPs to injunctive relief. With regard to specifically notified infringements of IPRs, this interpretation even seems to be unambiguous as the requirements to terminate or prevent infringements according to national law are to remain unaffected by the provisions of the Directive. However, this immediately raises the question of if and to what extent the ISP can also be obliged to prevent further future infringements, essentially comparable to the concrete infringement brought to the notice of the ISP. Indeed, the First Civil Senate of the German Bundesgerichtshof (Federal Court of Justice) has based its concept of the liability of providers as 'interferers' (so-called Störerbaftung limited to injunctive relief) upon the outlined restrictive interpretation of the liability privileges of the E-Commerce Directive - as not fully covering injunctive relief - and hence also had to develop criteria with regard to the scope of the obligation to prevent future comparable infringements

C-238/08 - Google France, paras. 106 et seq. See further on the interpretation of the Directive in the recent L'Oréal v eBay case, also infra III $2 \mathrm{~b}$.

${ }^{8}$ Cf., e.g., Recitals 3, 9 and 10, Enforcement Directive.

9 See Recital 23, Enforcement Directive.

10 See Recital 59, Information Society Directive.

${ }^{11}$ See explicitly Recital 45 as well as Art. 12(3), 13(3) and 14(3) E-Commerce Directive. 
(see infra III 1 for further details on that influential case law). Meanwhile, the European Court of Justice (ECJ) has developed a rather similar approach in its most recent judgment in L'Oréal v eBay (see infra III 2 b).

With regard to the interpretation of the substantive conditions of Art. 14 of the E-Commerce-Directive as such - an issue which is not at the centre of this analysis - the first emerging case law of the ECJ seems to tend towards an interpretation of the provision which limits the limitations on liability to cases where the service of the host provider is genuinely 'neutral'. Neutrality in that sense would mean that the service of the host provider as such is independent from the contents of the hosted or carried information and does not involve any direct interest of the provider as regards the specific contents of the carried or hosted information ${ }^{12}$. Indeed, according to the general objective of the 'safe harbour' rules, as it can be derived from Art. 15 of the E-Commerce Directive, only genuinely 'nentral' service providers in that sense should benefit from the privileges in the field of provider liability ${ }^{13}$. This is clearly acknowledged by Recital 42 which emphasises the limitation of liability exemptions to cases where the provider's activity is of a mere technical, automatic and passive nature. By contrast, 'active' providers offering a business model based upon their own (pecuniary or other) interest in the hosting of particular (infringing) information, which therefore directly or indirectly favour the carriage or hosting of certain (infringing) information or which even advertise this illegal use of their platform, should not be covered by the exemptions from liability as they no longer remain neutral in relation to the contents of the information they carry or host ${ }^{14}$.

Such balanced and differentiated interpretation of Art. 12 to 15 of the ECommerce Directive with regard to the limitations of ISPs liability has to be met with approval and should be perpetuated in further case law ${ }^{15}$. However, be that as it may, the issue of the existence and conditions of the contributory liability of ISPs for primary infringements by their users (which are in the centre of this analysis) needs to be determined in the first place. This is still a matter for national law, which is only partly harmonised by Art. 11 of the Enforcement Directive and Art. 8(3) of the Information Society Directive. Accordingly, the main structures of contributory liability in German, UK and French law shall

12 ECJ, joined cases C-236/08 to C-238/08 (supra, note 7), para. 106; Opinion of AG Maduro (supra, note 7), paras. 137 et seq. See further on the interpretation of the Directive in the recent L'Oréal $v$ eBay case, also infra III 2 b.

13 ECJ, joined cases C-236/08 to C-238/08 (supra, note 7), paras. 112 et seq.; Opinion of AG Maduro (supra, note 7), para. 144. See further on the interpretation of the Directive in the recent $L$ 'Oréal v eBay case, also infra III $2 \mathrm{~b}$.

14 ECJ, joined cases C-236/08 to C-238/08 (supra, note 7), paras. 113 et seq.; Opinion of AG Maduro (supra, note 7), para. 145. See further on the interpretation of the Directive in the recent $L$ 'Oréal v eBay case, also infra III 2 b.

${ }_{15}$ Leistner, Störerhaftung und mittelbare Schutzrechtsverletzung, GRUR Supplement $1 / 2010,1,27$ et seq. 
now be outlined, compared and measured against the (fragmentary) yardstick of European law (including the most recent European case law) in this field (see infra III).

\section{Provisions on TPMs and DRMs in the Information Society Directive}

As for European law, finally, it has to be emphasised that certain specific and independent provisions of European copyright law can - from this paper's perspective - also be regarded as referring to specifically regulated acts or technologies which enable users to commit infringements of IPRs and thus as atypical provisions on secondary liability in a broad sense. Therefore, e.g., the provisions on the adequate protection of TPMs and DRMs (Art. 6 and 7 of the Information Society Directive) undoubtedly have a certain impact on our topic. These particularly far-reaching provisions oblige Member States to provide legal protection against circumvention technology as such even, to a certain extent, independently from subsequent direct infringements by the users. In any case, they also contain certain principles of secondary liability which should not be undermined in the Member States' laws. Thus, in particular, the scope of these provisions - which is remarkably broad anyway - should in principle be regarded as conclusive as far as the harmonised area reaches. Consequently, contributory liability following from the delivery of de-encryption technology in the Member States' laws should at least never reach further than the area delimited by the specific provisions of the Information Society Directive for that area. Similar upstream provisions are, inter alia, already contained in Art. 7 of the Computer Programs Directive.

\section{Case Studies}

\section{Germany}

German case law on contributory liability for the infringement of IPRs is divided. Remarkably, the dividing line goes through the Bundesgerichtshof (Federal Court of Justice) itself. The First Civil Senate of the Federal Court of Justice has based its concept of the liability of mere contributors on the legal head of so-called 'interferer' liability (Störerhaftung). This applies to copyright and trade mark law ${ }^{16}$ (see a), below). By contrast, in the area of patent law, the Tenth Civil Senate traditionally follows a concept of contributory tortious

\footnotetext{
16 In the area of unfair competition law, the First Civil Senate has recently changed its approach and now bases contributory liability in that specific area on an independent head of tortious liability because of a (direct) act of unfair competition which lies in the facilitation of acts of unfair competition of third parties, see a), immediately below.
} 
liability which covers contributory acts as independent tortious infringements of patents in their own right (see b), below).

a) Störerbaftung in Copyright and Trade Mark Law

The traditional concept of Störerhaftung (interferer liability) has developed into the main tool that German law uses to deal with the contributory liability of internet platforms for the trade mark and copyright infringement of their users. This is mainly due to a series of three landmark decisions of the Federal Court of Justice in the Internet-Auction cases ${ }^{17}$. At the outset, the Federal Court of Justice held that an Internet Platform Provider is not tortiously liable as an infringer or participant in the infringing acts of its users as long as it had no actual and concrete knowledge of those acts. This is because tortious participation in an infringement, according to that case law, presupposes intention on the side of the participant as well as on the side of the principal.

However, according to the established concept of 'interferer' liability (Störerhaftung), any person who has wilfully made a causal contribution to the direct infringement of an IPR by third parties can be held liable for injunctive relief if the contributor has violated a reasonable duty of care to prevent such direct infringements. Accordingly, the action for an injunction, based on contributory liability because of Störerhaftung, involves three elements: a wilful adequate causal contribution to the infringing acts of any third party; the legal and factual possibility of preventing the resulting direct infringements; and the violation of a reasonable duty of care to prevent these infringements. The resulting Störerhaftung liability is limited to injunctive relief, including preventive injunctions, while damages cannot be claimed on that basis ${ }^{18}$. Typically, the injunctions also require the interferer (Störer) to take reasonable measures, such as filtering, to prevent further comparable infringements in the future. However, such preventive measures must not be unreasonably burdensome in the sense that the provider is required to take steps which would jeopardise its entire business model. Instead, only reasonable and technically possible measures in order to identify comparable infringements, i.e. offers of the same trader or comparable counterfeit goods, should be imposed.

The essential standard of reasonableness is determined by the Federal Court of Justice on a case by case basis taking into account all the facts of the case, including, inter alia, the role and function of the 'interferer', the degree of causation, i.e., the intensity of the danger of direct infringement, the possibility that the claimant might file an action against the direct infringers and other criteria.

17 BGH GRUR 2004, 860 - Internetauktion I; GRUR 2007, 708 - Internetauktion II; GRUR 2008, 702 - Internetauktion III; cf. also Bornkamm, E-Commerce Directive vs. IP Rights Enforcement: Legal Balance Achieved?, GRUR Int. 2007, 642.

18 BGH GRUR 2007, 708, at p. 709 et seq. - Internetauktion II. 
For host providers, such as internet platforms, this analysis leads to the conclusion that there is no reasonable duty of comprehensive ex ante examination of any infringing content that users may want to offer for sale or otherwise present. Thus, the internet provider cannot be expected to screen and control any content before it is available on the internet ${ }^{19}$. However, once a clear and specific infringement has been reported by the rightholder to have occurred, a reasonable duty, not only to remove the concrete infringing content from the platform, but also to implement measures in order to prevent a future repetition of comparable infringing acts, might arise $\mathrm{e}^{20}$.

On the basis of an interpretation of the E-Commerce Directive, which was mainly based upon the wording and systematic context of Art.14, namely Art. 14(3) of that Directive, the Federal Court of Justice came to the conclusion that Art. 14(1) of the E-Commerce Directive privileges the host provider only in relation to claims for damages and criminal liability, but not in relation to injunctive relief. Indeed, in light of its systematic context, the Court construed the wording of Art. 14(3) of the Directive as unambiguous in the sense of acte clair and therefore did not even refer the issue to the ECJ. In the light of the objectives of the E-Commerce Directive, namely Recital 45, this argument seems to be soundly defensible. However, as a follow-up problem, the crucial issue arises as to whether the duty to prevent future comparative infringement in context of the framework of injunctive relief does not effectively constitute a general obligation to monitor the stored information which must not be imposed on ISPs according to the general principle laid down in Art. 15 of the E-Commerce Directive. Indeed, the Federal Court of Justice has noticed this problem and has recently specified its case law to the end that even with regard to injunctions, the basic principle that no general obligation to monitor shall be imposed upon ISPs, remains applicable ${ }^{21}$. Accordingly, in its Jugendgefäbrdende Medien bei $e$ Bay-judgment the Court further clarified and specified which measures can be imposed on providers to prevent future comparable infringement: such measures are limited to adequate and reasonable filtering activities in relation to offers by the same user in the same category or with regard to infringements, characterised by the same main features found in the first infringing offer. In that regard, no obligation to prevent any future comparable infringement at any cost will be imposed upon the provider. Instead, only reasonable and economically feasible measures to prevent infringing offers of the same specific kind can be required of the provider. In that regard, the Federal Court of Justice takes the limitations of Art. 15 of the E-Commerce Directive - which has been implemented in Sec. 7 (2) $1 \mathrm{TMG}$ - explicitly into account.

19 Bornkamm (supra, note 17), p. 643.

20 Bornkamm (supra, note 17), p. 644.

${ }^{21}$ BGH GRUR 2007, 890 - Jugendgefährdende Medien bei eBay. 
The solution found by the Federal Court of Justice in its Internet-Auction case law indeed strikes a fair balance between IPRs and the interest of genuinely 'neutral'22 host providers ${ }^{23}$. In particular, it allows for the development of a flexible standard regarding the crucial element of contributory liability according to Störerbaftung, namely the reasonable duty of care to prevent direct infringement. Ideally, on that basis, the concept of Störerbaftung could provide adequate incentives for ISPs to take all reasonable and proportionate filtering measures to prevent IP infringement. However, this presupposes that a sufficient number of cases will be decided by the Federal Court of Justice in the future in order to provide for an adequate level of legal certainty in this area with regard to the necessary standard and specific elements of reasonable duties of care ${ }^{24}$.

As for the limitation of the concept of Störerhaftung to injunctive relief, it has been argued in the scholarly literature that the concept of indirect liability due to the violation of reasonable duties of care is also an established head of contributory tortious liability in general civil law (Haftung wegen Verkebrspflichtverletzung) and that therefore Störerhaftung could be developed into a tortious action of contributory liability on its own right. This would, consequently, also cover claims for damages. As a matter of course, in the area of provider liability, such claims for damages could only be granted subject to the specific conditions of Art. 12 to 15 of the E-Commerce Directive. However, beyond this specific area, a tortious construction of indirect liability for IPR infringement could result in an action, comparable to Störerhaftung with regard to the crucial element of the necessary violation of a duty of care, but no longer limited to injunctive relief.

In a more recent judgment, the First Civil Senate of the Federal Court of Justice did in fact base the liability of eBay for (prospective) acts of unfair competition by its commercial users upon the violation of an independent, tortious duty of care to prevent acts of unfair competition by third parties ${ }^{25}$. This was possible because the general clause of German unfair competition law, namely Section 3 of the German Unfair Competition Act (Gesetz gegen den unlauteren Wettbewerb), allows the Courts to broadly adapt and develop the concept of unfair

22 See the extrajudicial explanation of Bornkamm, (supra, note 17), p. 644. For 'active' providers which directly or indirectly influence their users to commit acts of direct infringement, a tortious liability for aiding and abetting has to be considered anyway, see further Leistner, Von "Grundig-Reporter(n) zu Paperboy(s)": Entwicklungsperspektiven der Verantwortlichkeit im Urheberrecht, GRUR 2006, 801, 808 et seq.; Leistner (supra, note 15), p. 5.

${ }^{23}$ See Bornkamm, (supra, note 17), p. 644.

24 This is because hitherto, the tendency in the case law of the lower courts has been to apply an over-stretched standard with respect to the specification of duties of care and therefore to over-extend the concept of Störerhaftung to very indirect causal acts. See further Leistner/Stang, Die Neuerung der wettbewerbsrechtlichen Verkehrspflichten - Ein Siegeszug der Prüfungspflichten?, WRP 2008, 533, 542.

25 BGH GRUR 2007, 890 - Jugendgefährdende Medien bei eBay. 
competition in case law. Therefore, the Federal Court of Justice argued that the creation of a relevant danger of (direct) acts of unfair competition by third parties (for example by providing a platform for such acts) in fact amounted to an act of unfair competition in itself, if the contributor did not fulfil the reasonable duty of care to control and limit the danger caused by his activity. Similarly, in a recent judgment, the First Civil Senate of the Federal Court of Justice has based the contributory liability of an $e B a y$-account holder for trade mark infringements, committed by using his account data, on a concept of tortious liability because of the violation of a duty of care by the account holder to effectively control the access to his own $e B a y$-account and to adequately protect his confidential account data. ${ }^{26}$ In fact, these judgments both find the existence of a tortious liability, consequently including the possibility of claims for damages, which are based upon three elements, namely: the creation of a relevant danger for direct acts of infringement by third parties; the legal and technical possibility of preventing such acts; and the violation of a reasonable duty of care to prevent these acts. Remarkably, according to the Jugendgefäbrdende Medien bei eBay-judgment, in that regard the standard for the duty of care can be structured along the lines of the case law on Störerhaftung. Therefore the concept of reasonableness is the same in the case law on tortious liability, specifically in the area of unfair competition, as it is in the case law on Störerbaftung with regard to the infringement of copyright and trade mark rights. Indeed, the parallel specification of the standard of reasonableness is perfectly justified as the contributory acts as well as their 'controllability' are exactly the same in these areas of IP law. However, this of course raises the question of why the legal consequences should be different in both areas. Therefore, this more recent case law as well as the obvious link to the concept of Haftung für Verkehrspflichtverletzung in general tort law implies the possibility of extending this new head of tortious liability to the areas of trade mark and copyright law. However, the Federal Court of Justice has clearly emphasised in both cases that these new concepts of tortious contributory liability shall be limited to unfair competition law, and to the specific area of account liability. Accordingly, in recent case law on the liability of the private operator of a WiFi-network the Court explicitly clarified that the findings of the Jugendgefäbrdende Medien bei eBay-judgement do not apply to trade mark and copyright law. ${ }^{27}$ The court refused to hold the operator of an insecure internet access that had been used by a third party for copyright infringement liable as an (additional) tortfeasor of this copyright infringement. The Court argued that the operator, who had not complied with his reasonable duty of care to secure the WLAN-access, had not fulfilled the specific requirements for infringement according to Section 19a (making available right) of the German Copyright Act

26 BGH GRUR 2009, 597 - Halzband.

27 BGH GRUR 2010, 633, 634 - Sommer unseres Lebens. 
(Urheberrechtsgesetz). According to the Court, this is because the operation of an insecure wireless connection cannot be equated with the specific act of making a copyrighted work available to the public.

Although this argument is not beyond doubt, taking into account this most recent case law, a change or development of the concept of Störerhaftung (as the central instrument of contributory liability in trade mark and copyright law) into a concept of tortious liability for any wilful negligent general contribution to infringing acts by third parties is not likely to occur in these areas of IP in the near future. However, remarkably, the Tenth Civil Senate follows this exact approach in patent law. Indeed, the Tenth Civil Senate has established an independent head of tortious liability for indirect infringement through wilful, negligent causation in a consistent series of judgments in patent law. That concept of tortious contributory liability, which consequently covers liability for damages, is in obvious contrast to the case law of the First Civil Senate in the areas of copyright and trade marks. This shall now be discussed.

\section{b) Contributory Liability in Patent Law}

German patent law - comparable to English and French law - provides for an explicit statutory tort of indirect patent infringement (Section 10 of the German Patent Act (Patentgesetz)) in respect of the offering or supply of the means for working an invention. Beyond the limitations of that particular statutory provision, the Tenth Civil Senate of the Bundesgerichtshof (Federal Court of Justice) has developed and upheld a tort of contributory patent infringement in case law $^{28}$. This claim is constructed as a tortious (indirect) liability for patent infringement; consequently, the action includes injunctions, damages and all other legal consequences which might follow from direct patent infringement.

In theory, the possible ambit of that action is broadly defined. Only three conditions must be fulfilled: the indirect patent infringer must have wilfully made an adequately causal contribution to the direct act of infringement; prevention of the infringement must have been legally and factually possible; and an element of negligence, namely the violation of a reasonable duty of care to prevent the infringement, must be present ${ }^{29}$. Although this sets a remarkably broad ambit for potential indirect liability for patent infringement, in the court's actual practice, the action has played a comparatively limited role. This is due to several factors. First, the relevant case law emphasises that indirect patent infringement must not undermine the limitations of the exclusive rights of the patent holder or the specific limitations in Section 10 Patentgesetz for indirect

28 BGH GRUR 1999, 977 - Räumschild; GRUR 2002, 599 - Funkuhr I; GRUR 2007, 313 - Funkuhr II; GRUR 2009, 1142 - MP3-Player-Import.

29 BGH GRUR 1999, 977, 979 - Räumschild; GRUR 2002, 599 - Funkuhr I; GRUR 2007, 313, p. 314 et seq. - Funkuhr II; GRUR 2009, 1142, 1145 - MP3-Player-Import. See further Leistner (supra, note 15), p. 9 et seq., especially 15 et seq. 
patent infringement by the offer or supply of essential means. Hence, the important issue of supply of essential means to work the invention is conclusively regulated in Section 10 Patentgesetz, while indirect tortious liability according to the case law of the Tenth Civil Senate will only be applicable for other groups of cases, such as the liability of the providers of infrastructure or similar accessory contributions. However, in particular, the liability of internet providers and other telecommunications infrastructure or similar contributory means to market or sell patented products or processes is simply not of the same practical relevance as it is with regard to trade mark or copyright infringement. This is because larger commercial or technological acts of infringement are still more typical in patent law infringement cases, while in trade mark and in particular, in copyright law 'atomistic' internet infringements by individual internet users have become very typical. Therefore, the possibility of filing claims against internet providers, who are in many of these cases placed in the key (and only) position to bring such activities effectively to an end, is much more needed in trade mark and copyright law. In patent law, the recent case law of the Federal Court of Justice centres on the liability of commercial carriers ${ }^{30}$ and on the liability for the upstream supply of patented products to foreign traders in countries, where no patent protection exists, when these traders subsequently export the patented products into the German market ${ }^{31}$.

Another reason, why the tortious action of indirect patent infringement has remained of comparatively limited relevance, might be the fact that the legal consequences - including damages - are decidedly farther reaching than the legal consequences of Störerbaftung-liability, which are limited to injunctive relief. Thus, the stronger legal consequences might have led to a more cautious handling of that type of liability in patent case law. Indeed, the difference between both sorts of liability is remarkable, given the fact that the facts of typical contributory liability cases in trade mark and copyright law today are more or less exactly the same as in patent law. However, in a recent judgment, the Tenth Civil Senate, after a very thorough discussion of the case law of the First Civil Senate of the Federal Court of Justice, upheld its position that a head of tortious indirect liability for knowing contribution or assistance to the direct infringement of third parties exists in patent law, when the participant does not comply with his reasonable duties of care to control and limit the risk that such direct infringements might occur. Hence, in patent law, neither specific knowledge of the direct acts of infringement nor a common design or procurement with regard to identifiable infringements is a condition of indirect tortious liability. Instead, a knowing contribution plus a violation of a reasonable duty of care (negligence) can trigger indirect tortious liability.

30 BGH GRUR 2009, 1142 - MP3-Player-Import.

31 BGH GRUR 2002, 599 - Funkuhr I; GRUR 2007, 313, 314 et seq. - Funkuhr II. 


\section{c) Conclusion}

In conclusion, a provisional statement of the basic structures of contributory liability in German law is that, beyond certain very specific statutory provisions (such as indirect patent and indirect trade mark infringement ${ }^{32}$ ), a dividing line separates German trade mark and copyright law from the legal situation in patent law. In trade mark and copyright law the concept of Störerbaftung provides for an action based on contributory liability because of the violation of a duty of care, which is limited to injunctive relief. In patent law - under essentially the same condition - tortious liability of the indirect infringer will arise which consequently provides for all of the legal consequences of patent infringement including damages. Thus, a general rule of contributory liability for all the different kinds of IP clearly does not exist in Germany.

Having said that, it has to be admitted that the basic elements which both types of contributory liability are composed of are essentially the same: adequate and relevant causation of the direct infringement, and a flexible duty of care. The extent of the latter mainly depends upon the facts of the case, namely the role and function of the participant (i.e. 'neutral' or 'active/biases'), the degree of the risk of direct acts of infringement created by the participant, the possibility of the claimant filing an action against the direct infringer and further criteria. Thus, while the elements of contributory liability are essentially the same in trade mark, copyright and patent law, the legal consequences are not. In the most recent German academic literature, increasing attention has been paid to the inner inconsistency of the German approach(es) to contributory liability. Against the background of indirect liability because of Verkehrspflichtverletzung (violation of duty of care) in general German tort law, it has been argued that this contradiction should be solved by accepting a concept of tortious indirect liability in copyright and trade mark law modelled along the lines of the case law on Störerbaftung but providing not only for injunctive relief but also for damages. In fact, the most recent judgment of the First Civil Senate of the Federal Court of Justice on the contributory liability of an $e B a y$-account holder which included damages, even seemed to point cautiously in that direction. However, the Court was very eager to emphasise that this case was a special case and shall not be generalised in the future.

Thus, for the moment the split legal situation with regard to contributory liability in Germany will continue to exist. In fact, remarkably, the different concepts of the different Senates of the Federal Court of Justice can be found in other Member States of the European Union as will be shown in the following discussion of French and UK rules and principles on contributory liability.

\footnotetext{
32 See Sec. 14(4) Trade Mark Act.
} 


\section{United Kingdom}

\section{a) Joint Tortfeasance}

In this regard, beyond specific statutory provisions, such as the provisions on indirect patent and trade mark infringement (sections 60(2), UKPA 1977; 9, 10, Trade Marks Act 1994) as well as some specific provisions of the CDPA on certain contributory acts in copyright law (cf. sections 22-26, CDPA 1988), UK common law and equity are decidedly more contained with regard to contributory liability for IPR infringements than German law. UK common law and in particular the law relating to joint tortfeasance governs the issue of accessory liability for IPR infringement in England and Wales. Thus, in contrast to German law, in principle, the rules governing contributory liability in the case law are applicable to the infringement of all kinds of IPRs alike, as they reflect the general principles of tort law.

The basic principles were laid down in the two $A m s t r a d$-cases ${ }^{33}$, concerning the use of Amstrad tape recorders for copyright infringement by the purchasers of this equipment. It was held that merely supplying with knowledge and intent, a machine which is capable of being used for lawful or unlawful purposes, is not enough to make the supplier himself an infringer or a joint tortfeasor with someone who uses that machine to infringe copyright. In particular, as Amstrad had no control or specific interest in the subsequent use of its models by the purchasers, the necessary precondition for joint tortfeasance, i.e. that the joint infringers acted pursuant to a common design, was clearly not present in these cases. Moreover, Amstrad did not make or authorise other persons to use its models for copyright infringement nor did it in any other way procure subsequent direct infringements of copyright by inducement, incitement or persuasion. However, such identifiable procurement of a particular infringement is a necessary precondition of joint infringement according to CBS Songs Ltd. $v$ Amstrad. The mere fact that the use of Amstrad equipment facilitated infringement, and that Amstrad knew that generally it was serving a market for devices which could (and would) be used by some purchasers for direct infringement, was not enough for procuring the doing of the direct acts of infringement. Consequently, Amstrad did not owe any duty of care to prevent, discourage or warn against infringement.

Further case law on patent infringement as well as on joint tortfeasance in general has affirmed the limitation of the concept of indirect infringement to the two main categories of joint tortfeasance, i.e. procurement or participation in a common design $n^{34}$. The most far-reaching decision (Unilever v Gillette) acknow-

33 Amstrad Consumer Electronics Plc v British Phonographic Industry Limited, [1986] FSR 159; CBS Songs Ltd. and Others v Amstrad Consumer Electronics PLC and other, [1987] 2 WLR 1191.

${ }^{34}$ See Unileverv Gillette, [1988] RPC 105 (18) 416 (on patent infringement); Credit Lyon- 
ledged that tacit agreement might suffice for participation in a common design. However, 'mere assistance, even knowing assistance' does not suffice according to established case $\mathrm{law}^{35}$. In particular, "merely acting as a supplier of goods to a purchaser which was free to do what it wanted with the goods" will not suffice for procurement or concerted action in the sense of participation in a common design ${ }^{36}$.

In the most recent UK case on provider liability, i.e. the Judgment of the High Court in L'Oreal v eBay on the indirect liability of eBay for alleged trade mark infringements by its users, Mr. Justice Arnold held that the overall effect of these cases was that eBay could not be held liable as the company had neither identifiably procured particular infringements of its users nor participated in a common design with them ${ }^{37}$. In fact, as for the participation in a common design, the issues of the genuine 'nentrality' of eBay as well as the lack of control over the automatically processed offers and the absence of any duty of care in common law to prevent direct acts of infringement by users, were of crucial importance in reaching that result.

The insurance factor, i.e. the question of who could most easily insure against the risk of IP infringements in such cases ${ }^{38}$, which played a significant role in the reasoning of Mr. Justice Arnold, did eventually not change that result. Indeed, Mr. Justice Arnold explicitly acknowledged a certain sympathy with the suggestion that eBay could and should deal with the problem of infringement by accepting liability and insuring against this risk by means of a premium levied on its sellers as the platform created a new form of trade which carried with it a higher risk of infringement than more traditional methods of trade ${ }^{39}$. However, despite this argument he found no way to establish eBay's liability in terms of participation in a common design. In particular, although the judge explicitly considered it 'anomalous' that eBay applied a different standard of preventive activities in different Member States of the Community (allegedly just doing the minimum necessary in each Member State to prevent indirect liability), in the judgment it was held that "no inbuilt bias or tendency in favour of infringing activities" could be identified in eBay's systems or policies ${ }^{40}$. From that, it follows that if such a bias or tendency could be identified, i.e. if eBay did not act as a genuinely neutral platform, participation in a common design by tacit agree-

nais v Export Credit Guarantee Department, [1999] 1 Lloyd's Rep. 563 (on general tort law); SABAFv Meneghetti, [2005] RPC 122 (7) 209 (on patent infringement).

${ }_{35}$ Credit Lyonnais v Export Credit Guarantee Department (supra, note 34).

36 SABAFv Meneghetti (supra, note 34).

37 L'Oreal v eBay, [2009] EWHC 1094 (Ch), paras. 359 et seq.

${ }^{38}$ See - in a completely different context - e.g. R.H. Willis \& Sonv British Car Auctions Ltd. [1978] 1 WLR 438.

39 L'Oreal v eBay (supra, note 37), para. 370.

40 L'Oreal v eBay (supra, note 37), paras. 376 et seq. 
ment should at least be considered ${ }^{41}$. However, the mere facilitation of direct infringement by (general) knowledge and an intention to profit was not sufficient to establish liability as a joint tortfeasor ${ }^{42}$.

Besides, Mr. Justice Arnold affirmed that under common law eBay was under no general duty of care to take "all reasonable measures" to prevent infringements and therefore could not be regarded as jointly liable for direct infringements by its users because of any non-compliance with such a duty of care ${ }^{43}$. Indeed, the judgment emphasises that liability cannot be established based upon the violation of a duty of care if that duty of care itself mainly specifies (and limits) the liability established in the first place. Indeed, this would amount to a circular argument ${ }^{44}$. Against the background of established case law on joint tortfeasance this result is undoubtedly consistent.

However, it ought to be noted that several passages of the judgment emphasise the significance of the substantial risk of IPR infringements which eBay creates as well as the fact that at least in certain specific situations, such as imports from non-EEA countries on the eBay-platform, the company comes very close to a biased role in favour of direct acts of infringement. In the light of the insurance factor and in particular in the light of the framework of European law, namely Art. 11 of the Enforcement Directive on the liability of intermediaries, an argument might be made in favour of establishing eBay's liability as a joint tortfeasor and specifying the conditions and extent of such liability by flexibly interpreting the duties of care to take all reasonable measures to prevent infringement. This would correspond to the broadly drafted concept of contributory tortious liability in German patent law. Mr. Justice Arnold, however, regarded that way as closed because - in contrast to the general principles of German tort law - mere facilitation with knowledge and intent cannot suffice to establish tortious liability for the infringement of an IPR under English law. In fact, in order to establish liability in such cases it would be necessary to acknowledge a third category of tortfeasance in the case of mere knowing facilitation of direct acts of infringement by way of supplying technology or other infrastructure which is necessary for committing these acts. If such a third category were established, the specific conditions and extent of such liability could subsequently be consistently limited and specified on the basis of a flexible standard of the reasonable duty of care to prevent direct acts of infringement which might evolve in the case law. However, the potential break that this new cate-

41 That complies with the general tendency in Europe to subject 'active' providers to stricter liability than 'neutral' providers, cf. Leistner (supra, note 22) pp. 805, 809 et seq.; Opinion of AG Maduro (supra, note 7), para. 144.; ECJ, joined cases C-236/08 to C-238/08 (supra, note 7), paras. 112 et seq.

${ }^{42}$ L'Oreal v eBay (supra, note 37), para. 382.

${ }^{43}$ L'Oreal v eBay (supra, note 37), paras. 372 et seq.

${ }^{44}$ L'Oreal v eBay (supra, note 37), para. 373. 
gory of liability might signify for the general principles of tort in the UK cannot be denied. Therefore - notwithstanding his sympathy for establishing the liability of the 'cheapest risk insurer' and notwithstanding certain facts which distinguish such 'platform cases' from the facts in Amstrad ${ }^{45}$ - Mr. Justice Arnold refrained from offering such a bold solution. Instead, in light of the alleged (and comparatively limited) European obligation to establish the possibility for seeking injunctive relief against intermediaries, the court turned to equitable injunctions as a possible remedy in UK law.

\section{b) Equitable injunctions and the ECJ's ruling in L'Oréal v eBay}

As for the starting point in European law, the judgment referred the questions of whether, and to what extent (with regard to the prevention of future comparable infringements) Art. 11 of the Enforcement Directive required that injunctions against an intermediary which is not an infringer should be available in the domestic law of the Member States, to the ECJ by way of preliminary reference according to Art. 234, EC (now Art. 267, TFEU) ${ }^{46}$. Moreover, the court planned to seek clarification on the exact scope of the defence that Art. 14 of the E-Commerce Directive provides for eBay as a host service provider ${ }^{47}$. Related reference questions were formulated and referred to the ECJ ${ }^{48}$.

${ }^{45}$ L'Oreal v eBay (supra, note 37), para. 369.

46 ''Oreal v eBay (supra, note 37), paras. 455 et seq. (in particular para. 465).

47 L'Oreal v eBay (supra, note 37), paras. 432 et seq., 481.

48 See Case C-324/09-L'Oreal v eBay, Reference for a preliminary ruling from the High Court of England and Wales, OJ C 267/40 of 7 November 2009, Question 10: "Where the services of an intermediary such as an operator of a website have been used by a third party to infringe a registered trade mark, does Art. 11 of European Parliament and Council Directive 2004/48 of 29 April 2004 on the enforcement of intellectual property rights ('the Enforcement Directive') require Member States to ensure that the trade mark proprietor can obtain an injunction against the intermediary to prevent further infringements of the said trade mark, as opposed to continuation of that specific act of infringement, and if so what is the scope of the injunction that shall be made available?"; Question 9: "If it is sufficient for such use to fall within the scope of Art. 5(1)(a) of the Trade Marks Directive and Art. 9(1)(a) of the CTM Regulation and outside Art. 7(1) of the Trade Mark Directive and Art. 13(1) of the CTM Regulation that the advertisement or offer for sale is targeted at consumers in the territory covered by the trade mark: (a) does such use consist of or include 'the storage of information provided by a recipient of the service' within the meaning of Art. 14(1) of the E-Commerce Directive? (b) if the use does not consist exclusively of activities falling within the scope of Art. 14(1) of the E-Commerce Directive, but includes such activities, is the operator of the online marketplace exempted from liability to the extent that the use consists of such activities and if so may damages or other financial remedies be granted in respect of such use to the extent that it is not exempted from liability? (c) in circumstances where the operator of the online marketplace has knowledge that goods have been advertised, offered for sale and sold on its website in infringement of registered trade marks, and that infringements of such registered trade marks are likely to continue to occur through the advertisement, offer for sale and sale of the same or similar goods by the same or different users of the website, does this constitute 'actual knowledge' or 'awareness' within the meaning of Art. 14(1) of the E-Commerce Directive?”. 
In its recent ruling ${ }^{49}$, the ECJ has refined its interpretation of the scope of Art. 14 of the E-Commerce Directive and has clarified the fundamental relationship of Art.12-15 E-Commerce Directive to Art. 11 of the Enforcement Directive thereby developing a line of precedent on the intermediary liability of online service providers.

The ECJ picks up the threads of the Google France rulings ${ }^{50}$, emphasising that the safe-harbor privilege of Art. 14 of the E-Commerce Directive merely applies to neutral activities of the operator of the online market place, as opposed to an active assistance in the contested activities of the direct infringers ${ }^{51}$. Leaving the fact-specific consideration to the High Court for further determination, the Court observes that eBay would be barred from invoking the HostProvider clause if it procured the sellers' (i.e. the direct infringers') offers of the trademark-infringing products on its platform either by means of optimising the presentation of the respective offers or their (direct) advertisement and was thus able to gain knowledge of, or control over the stored information linked to the contested offers ${ }^{52}$. Assuming arguendo that $e$ Bay's role with respect to the offers in question was limited to a merely neutral activity compliant with the principles established in the Google France cases, the ECJ finds that according to Art.14(1)(a), eBay would nevertheless be prohibited from relying on the exemption from liability, "if it was aware of facts or circumstances on the basis of which a diligent economic operator should have realised that the offers for sale in question were unlawful and, in the event of being so aware, failed to act expeditiously in accordance with Article 14(1)(b) of Directive 2000/31" 53.

After having specified the scope of Art. 14 of the E-Commerce Directive, the ECJ finally addresses the crucial question of European intermediary liability law, i.e. the notorious tension between Art. 12-15, in particular Art. 15(1), of the E-Commerce Directive and the third sentence of Art. 11 of the Enforcement Directive and the related question of if and to what extent Member States are required to provide for injunctive relief, covering the prevention of future infringing activities ${ }^{54}$. The Court explicitly recognizes the necessity of preventing future infringement as legitimate goal of injunctions directed at third parties (i.e. the intermediaries) in order to reach the objective of the Enforcement Directive, i.e. the effective protection of intellectual property ${ }^{55}$. As to the crucial issue of how to design and limit such injunctive relief with regard to preventive measures in order to balance the principle of effective protection with the

\footnotetext{
49 ECJ, Judgment of 12 July 2011, case C-324/09 - L'Oréal v eBay.

50 See further infra III 3.

51 Case C-324/09 - L'Oréal v eBay (supra, note 49), paras. 112 et seq.

${ }^{52}$ Case C-324/09 - L'Oréal v eBay (supra, note 49), para. 116.

53 Case C-324/09 - L'Oréal v eBay (supra, note 49), paras. 118 et seq.

${ }^{54}$ Case C-324/09 - L'Oréal v eBay (supra, note 49), paras. 125 et seq.

55 Case C-324/09 - L'Oréal v eBay (supra, note 49), paras. 131 et seq.
} 
provisions of the E-Commerce-Directive and the principle of proportionality, the Court emphasises that an obligation of online service providers to actively monitor the data and information of every single user would be disproportionate according to Art. 15(1) of the Enforcement Directive ${ }^{56}$. Likewise, according to Art. 3 Enforcement Directive, injunctions providing for certain preventive duties must not create barriers to legitimate trade and therefore e.g. must not have as their object or effect a general and permanent prohibition on the selling of goods bearing certain trade marks on the concerned internet marketplace ${ }^{57}$. As possible effective and proportionate preventive measures, the Court suggests the requirement of the platform operator to suspend certain users ${ }^{58}$ or to take measures to make it easier to identify commercial infringers (notwithstanding the necessary protection of personal data) ${ }^{59}$. Apart from these non-exhaustive suggestions, the Court emphasises the general principles that injunctions requiring preventive measures have to be "effective, proportionate, dissuasive and must not create barriers to legitimate trade" 60 .

Prior to the ECJ's response, The High Court judgment had already considered the issue of whether a court of equity had the power to grant injunctive relief in relation to contributory activities of a host provider in respect of the direct infringements of the users of the service. According to section 37(1) of the Supreme Court Act 1981 and the related case law ${ }^{61}$, the power of the High Court to grant equitable injunctive relief by (interlocutory or final) order is, in principle, unlimited. According to the leading authorities in the case law, however, the actual exercise of that power is limited to situations where a party has invaded or threatens to invade a legal or equitable right of the claimant or where a party has behaved or threatens to behave in a manner which is unconscionable. This broad ambit of possible injunctive relief with regard to the (imminent or alleged) infringement of legal or equitable rights in the case law has even once been specified to apply in a situation, where the defendant was in possession or control of goods, the dissemination of which would have infringed the claimant's patent or trade mark rights ${ }^{62}$. Although the case law on shippers and

56 Case C-324/09 - L'Oréal v eBay (supra, note 49), para. 139.

57 Case C-324/09 - L'Oréal v eBay (supra, note 49), para. 140.

58 Case C-324/09 - L'Oréal v eBay (supra, note 49), para. 141; cf. also Opinion of AG Jääskinen in case C-324/09, para. 182.

59 Case C-324/09 - L'Oréal v eBay (supra, note 49), para. 142.

60 Case C-324/09 - L'Oréal v eBay (supra, note 49), paras. 138 et seq. In the very recent Judgement of 24 November 2011, case C-70/10 - Scarlet Extended SA $v$ SABAM, the ECJ has further specified that an internet service provider (in the specific case an access provider) must not be obliged by an injunction to install a system for filtering all electronic communications passing via its services at its own expense when this effectively applies indiscriminately to all its customers as a preventive measure and for an unlimited period.

61 Cf. the comprehensive references in L'Oreal v eBay (supra, note 37), para. 449.

62 Norwich Pharmcal Co. v Customs and Excise Commissioners, [1974] AC 133, para. 452. 
comparable persons who have the allegedly infringing goods in their possession, custody or control, can clearly be distinguished from the facts in the eBay case, a court of equity would, in principle, have the power to grant an injunction against an intermediary to protect an IPR against infringement if Art. 11 of the E-Commerce Directive required the court to do so in domestic law. As Mr. Justice Arnold has pointed out, this would not amount to Art. 11 of the ECommerce Directive having direct effect in the UK. Instead, Art. 11 of the ECommerce Directive would provide the principled basis for the exercise of an existing jurisdiction in a new way.

From this, it seems to follow that if European law requires the grant of an injunction against intermediaries, such as eBay, in a concrete case the High Court will now comply with this requirement of European law by extending the equitable principles on injunctive relief in cases where an IPR is allegedly infringed or threatened to be infringed. The scope of related orders will be defined according to the relevant obligations in European law as they have now been laid down by the ECJ. The granting of such injunctions against persons who, by their contribution, allegedly cause the infringement of an IPR or threaten to cause such infringement obviously comes very close to the German concept of Störerhaftung (interferer liability) of the First Civil Senate of the Bundesgerichtshof (Federal Court of Justice) in relation to copyright and trade mark infringements on the internet. Indeed, the High Court was explicitly inspired by the Internet-Auction series of cases, and by associated extra-judicial explanations of the President of the First Civil Senate, Joachim Bornkamm ${ }^{63}$.

\section{c) Conclusion}

To sum up the present situation in common law and equity after the judgment in L'Oreal v eBay: Mr. Justice Arnold suggests a two-tier system of traditionally limited tortious liability (including the possibility of damages claims) for genuine cases of joint infringement, where the intermediary's specific knowledge and (inducing or collaborating) activity in relation to particular infringements or at least the clearly (objectively) biased position of the intermediary as a basis for suggesting a tacit agreement on a common design to infringe IPRs can be shown; and a broader concept of equitable contributory liability for merely causing the direct infringements of third parties, limited, however, to injunctive relief. Remarkably, such a system of contributory liability in English law would structurally correspond to the case law of the First Civil Senate of the Federal Court of Justice on contributory liability for copyright and trade mark infringement in German law. In the future, this solution would fulfil the minimum requirements of European law on the liability of intermediaries as they have now been laid down by the ECJ in its L'Oréal v eBay judgment.

${ }^{63}$ Cf. L'Oreal v eBay, (supra, note 37), paras. 455 et seq. 
At the same time it has to be borne in mind that an alternative concept of contributory liability exists in German law which has not been noticed by the High Court. In the field of patent law, the case law of the Tenth Civil Senate establishes tortious liability for each adequate causation of the infringement of an IPR where the participant did not comply with her reasonable duties of care, and, therefore, acted negligently. Such broad contributory tortious liability is consistently limited by applying strict criteria as to the standard of the flexible duty of care. In UK law such a broader concept of tortious liability does not exist. The establishment of a comparable figure of secondary liability in the English law of torts would go beyond the minimum requirements of European law. As for the domestic law of England and Wales, it would in fact establish a new third category of joint tortfeasance (in IP) on the grounds of the mere knowing and negligent facilitation of direct acts of infringement by third parties. The establishment of such a new tort does not seem likely in the near future. Paradoxically, however, this exactly mirrors the more hands-on approach of the French courts to contributory liability which will now be discussed.

\section{France}

As for specific statutory provisions on the indirect infringement of IPRs, French law provides for a specific provision concerning the supply of means for patent infringing use of an invention (Art. L.613-4 CPI). However, a specific provision on indirect trade mark infringement does not exist in French law. Moreover, the transposition of the Information Society Directive's provisions on the protection of TPMs and DRMs can be regarded as a specific regulation of indirect IPR infringement in the broad sense (cf. also supra II 3 on the situation in European law).

More important than these special statutory provisions is the general basis of contributory liability in French civil law, i.e. the case law on Art. 1382 and 1383 of the Code Civil. The relevant rules are part of the general law of torts and are thus of a general nature. Consequently, at the outset these rules apply to the infringement of all kinds of IPRs. According to the broad general clause of Art. 1382 of the Code Civil, the elements of tortious liability are: damage to the claimant, which was caused by an act of the defendant, and faute on the side of the defendant (which might be due to intent or negligence according to Art. 1383 of the Code Civil). Within this broad framework of general tort liability, any contributory liability in the field of IPR infringement can be covered on the essential condition that the defendant acted negligently, i.e. that a reasonable duty of care was disregarded by the defendant. Consequently, French Courts have established a fairly broad concept of contributory liability according to Art. 1382 and 1383 of the Code Civil. The remedies for this action are not limited to injunctive relief. Instead, because the (negligent) contributory causa- 
tion is regarded as a tort, all measures and remedies applicable to direct IP infringement (including damages) will also be available against a contributory or secondary infringer. A multitude of direct and indirect infringers will be jointly and severally liable for damages claims. Therefore, the basic structure of the French system of contributory liability corresponds to the broad construction of tortious liability which the First Civil Senate of the Federal Court of Justice has established in respect of German patent law.

In principle, French Courts have approached the most practically pertinent area of contributory liability, i.e. the different provider liability cases, on the basis of this framework of general tort law. Thus, a provider can be liable as a contributory infringer if it has adequately caused acts of direct infringement, and has acted negligently because it disregarded reasonable duties of care to identify and prevent direct acts of infringement. In early French case law, such duties of care were specified by the courts rather rigorously. Therefore, in some lower court cases Google was held liable as a tortious infringer because it offered the AdWords program without taking reasonable measures, such as an ex ante control, to prevent the registration of trade mark protected keywords ${ }^{64}$. As a matter of course, such a broadly drafted contributory liability concept in general tort law necessarily came into conflict with the 'safe harbour' rules of Art. 12 to 15 of the E-Commerce Directive in the area of provider liability. These limitations on liability have been implemented in French law by Article 6 of the Loi $n^{0} 2004-575$ du 21 juin 2004 pour la confiance dans l'économie numérique. Consequently, in three of these cases the Cour de Cassation referred different legal issues concerning Google's activities (as direct trade mark infringements or because of role as an intermediary) to the ECJ for an Art. 234 judgment (now Art. 267, TFEU ${ }^{65}$. As for contributory liability, the crucial issue was whether Google's AdWords Service is privileged by Art. 14 of the E-Commerce Directive on the limited liability of host providers. AG Maduro emphasised in his opinion on the liability of Google that while in principle the E-Commerce Directive is applicable to Google's AdWords Service, this service should not be covered by the 'safe harbour' provision of Art. 14 of the E-Commerce Directive. This is because the main objective of that provision is to privilege genuinely 'neutral' host providers on the internet - in particular in relation to ex ante control (cf. Art. 15 of the E-Commerce Directive) - and Google's AdWords service influences the

${ }^{64}$ Appeal cases: Cour d'appel de Versailles, Judgment of 10 March 2005 - Google v Viaticom, Luteciel (Bourse des Vols), Cour d'appel de Versailles, Judgement of 23 March $2006-$ CNRRH, Pierre Alexis v. Google and Tiger; Cour d'appel d'Aix en Provence, Judgement of 6 December 2007 - TWD Industries v. Google France, Google Inc. The only decision to exclude liability: Cour de Strasbourg, Judgement of 20 July 2007 - Atrya v. Google and K par K/TechniFeneres.

${ }^{65}$ Cases C-236/08 - Google v. Louis Vuitton; C-237/08 - Google v. Viaticum; C-238/08 Google v. CNRRH, referred by Cour de Cassation, Judgment of 20 May 2008 (three cases). 
hosted content and specifically profits from certain content and therefore cannot be regarded as 'neutral' as regards the hosted content as such ${ }^{66}$. As for a concept of contributory infringement, AG Maduro did not recommend that the ECJ should adopt such a wide understanding of the concept of trade mark infringement in European trade mark law ${ }^{67}$. In the meantime, the ECJ has decided on this question - along with other similar questions referred to it by national courts of other Member States -, largely adopting the recommendations of AG Maduro (at least with regard to the aforementioned issue). ${ }^{68}$ Regarding the applicability of the 'safe harbour' rules, the Court held that it was necessary that the conduct of the service provider should be limited to that of an 'intermediary service provider' within the meaning intended by the legislature in the context of Section 4 of the E-Commerce Directive. Accordingly, in order to establish whether the liability of a referencing service provider may be limited under Art. 14 of the Directive, the Court considered it necessary to examine whether "the role played by that service provider is neutral, in the sense that its conduct is merely technical, automatic and passive, pointing to a lack of knowledge or control of the data which it stores". The ECJ further emphasised that the mere facts that the referencing service is subject to payment, that the service provider sets the payment terms or that it provides general information to its clients cannot have the effect of depriving the service provider of the exemptions from liability provided for in the Directive.

On the general concept of contributory liability in French law it has to be held that in principle contributory liability will be triggered in the case of any wilful and negligent causation of IP infringement by third parties. The main limiting factor to that broad concept of tortious liability is the element of fante, i.e. intent or negligence, and therefore the specific standard of reasonable $d u$ ties of care in certain areas. If the defendant has not complied with such reasonable duties, contributory liability might be addressed by all the remedies and measures which are applicable in a case of direct IP infringement. The structure of this concept does indeed come very close to the concept of the Tenth Civil Senate of the Federal Court of Justice in German patent law.

${ }^{66}$ See further supra at III.1.a).

67 Opinion of AG Maduro (supra, note 7), paras. 114 et seq., 141 et seq.

${ }^{68}$ ECJ, joined cases C-236/08 to C-238/08 (supra, note 7), paras. 112 et seq. 


\section{Perspective: Common Principles of Secondary Liability?}

The quest for common principles of secondary liability for the infringement of IPRs in Europe faces a double challenge. First, the question has to be answered whether there are common principles of secondary liability with regard to different kinds of IPRs. Second, as a matter of course, the answer to that first question, as well as the availability and conditions of actions concerning joint and contributory liability, may differ in the laws of the different Member States. Therefore, the question has to be answered whether common identifiable principles of secondary liability exist in the different Member States' laws. The answer to this second question is obviously influenced by the framework of secondary Community law in the field which must therefore also be taken into account.

Moreover, with regard to the foundation of contributory liability a further distinction ought to be made at the outset. On the one hand, in many Member States' laws contributory liability is governed by the general principles of 'joint tortfeasance', 'procurement' or comparable heads of tortious liability. On the other hand, certain statutory provisions, such as provisions concerning contributory patent infringement as well as provisions (in some Member States) concerning contributory trade mark infringement provide for specific rules on the liability of certain suppliers of technology and other indirect infringers. Thus, secondary liability in the general case law on tortious liability for the infringement of IPRs and the different kinds of specific statutory heads of 'upstream' liability which may be provided for by statutes governing the different kinds of IPRs must be distinguished.

The resulting matrix of the quest for common principles of secondary liability is obviously very complex. It consists, firstly, of the necessary distinction between general principles of tortious liability for the infringement of IPRs and specific statutory provisions on the liability for certain 'upstream' contributory acts; secondly, of the issue of whether the resulting principles are similar for the different kinds of IPRs; and thirdly, of the question of whether, in that regard, certain common principles can be identified throughout Europe. Against this complex background, and considering the limited time frame of the Conference, focus on the fundamental structures is needed in order to identify at least some preliminary guidance for future research in the area. Consequently, I have limited the quest for common principles in Europe to the level of the basic structures of secondary community law (see supra II) and to a brief discussion of three instructive case examples from Member States laws (see supra III).

To sum up the outline of selected European Member States' laws: beyond specific statutory provisions, namely on indirect patent and/or trade mark infringement by supply of certain essential means to use a patented invention or a 
trade mark in the course of trade, the range of rules governing contributory liability for IPR infringement in European law is varied.

As for the first question, whether there are common rules for the different kinds of IPRs, no general answer can be given. While in English and French law, the concepts of contributory liability are consistently rooted in the general principles of tort law (or equity), in Germany, two structurally different concepts co-exist in copyright and trade mark law on the one hand and in patent law on the other. Remarkably, while the concept of Störerbaftung (interferer liability, limited to injunctive relief, in German trade mark and copyright case law) seems to have the potential to inspire future legal development in English equity, the concept of tortious liability for facilitating direct infringements by third parties (including claims for damages in German patent case law) corresponds structurally to the broad construction of the general clause of French tort law in the field of contributory liability in IP cases. Against this background, the question of which of these concepts will prevail in future European law seems to be of crucial importance.

The framework of secondary European law is comparatively limited for the time being. While Art. 11 of the Enforcement Directive and Art. 8(3) of the Information Society Directive oblige the Member States to provide for the possibility of injunctive relief against 'intermediaries', Art. 12 to 15 of the E-Commerce Directive limit the liability of ISPs in the most notorious and relevant area of contributory liability, that is, IPR infringements on the internet. The scope of Art. 11 of the Enforcement Directive and Art. 8(3) of the Information Society Directive as well as the exact relationship between these obligations and Art. 12 to 15 of the E-Commerce Directive have to be specified by the ECJ. The judgment in the first three (French) Google cases, and in particular, the most recent ECJ ruling in the L'Oreal v eBay case have provided for some guidance in that regard. In principle, the Court's solution for trade mark infringements on internet platforms in the recent L'Oréal v eBay judgment comes rather close to the Bundesgerichtshof's (Federal Court of Justice's) concept of Störerhaftung (interferer liability): the ECJ holds that injunctive relief has to cover the requirement of certain effective and proportionate measures to prevent future infringements which however must not amount to an active monitoring of all the data of each of the customers of the platform and which must not create barriers to legitimate trade. Moreover, the Court suggests some concrete preventive measures which can be imposed on the providers (in a non-exhaustive way) and emphasises the principle that such measures must be effective and dissuasive as well as proportionate.

Notwithstanding the remarkable differences in the structure and legal consequences of contributory liability (in the sense of legal rules), certain common elements of assessing secondary liability (in the sense of more general principles) can nevertheless be identified. Specifically, as objective factors, the degree of the 
(objective) risk caused by the secondary infringer as well as the degree of control the secondary infringer has in relation to the acts of direct infringement, play a significant role in assessing contributory liability. Moreover, the (objective) design of a business model of an intermediary might establish tortious liability where the business model is specifically designed to profit from direct acts of infringement and therefore is characterised by an inbuilt bias towards infringing uses ('active intermediaries' as opposed to 'neutral intermediaries' whose service can be used for legal or illegal purposes equally). Subjectively, actual and specific knowledge of particular infringements is an important element to delineate the area of tortious liability in many Member States' laws. As for 'neutral intermediaries', general knowledge of the facilitation of direct acts of infringement might be an element of establishing secondary liability beyond the area of tortious liability in the framework of concepts such as interferer liability (in German law) or in the framework of equitable jurisdiction (in England and Wales). Here, additional values of a general nature must still come into play such as the interest in the maintenance of an adequate level of protection of personal data, as well as of a neutral infrastructure of the reasonably free and unrestrained exchange of information as well as free competition within the network. The situation of the right holder is also of relevance: thus, secondary ('upstream') liability will typically be established in situations where it is impossible or impractical to pursue each individual direct infringement.

In Germany and in many other Member States as well as globally ${ }^{69}$, the crucial limiting factor of secondary liability is non-compliance with a reasonable duty of care to prevent direct acts of infringement. The flexible standard of reasonableness (or proportionality) is adjusted in the case law by assessing all the facts of a particular case, specifically in the framework of the structural guidance which has been outlined in the preceding paragraph. In principle, this solution seems to provide for a capable framework within which to develop a fair balance of interests for the main case groups of secondary liability, and in particular, for the notorious ISP cases. In its most recent judgment in L'Oréal v eBay, the ECJ constructs Art. 11 of the Enforcement Directive along very similar lines. The obvious main issue, however, is the appropriate adjustment of the threshold of reasonableness (or proportionality) of necessary preventive measures under conditions of informational uncertainty.

Given the leeway necessary for the Courts, case law can develop an appropriate standard of reasonableness (or proportionality) over time. The advantage of this solution lies in the fact that such case law will typically represent a fair balance of all the involved interests as it results from a weighing of all the relevant

69 Spindler/Leistner, Secondary Copyright Infringement - New Perspectives in Germany and Europe, 37 IIC 788, 820 et seq. (2006); Spindler/Leistner, Die Verantwortlichkeit für Urheberrechtsverletzungen im Internet - Neue Entwicklungen in Deutschland und in den USA, GRUR Int. 2005, 773, 795 et seq; Leistner (supra, note 22) p. 804, 813. 
factors in the framework of various court proceedings. However, this presupposes the existence of certain institutional conditions. In particular, a sufficient number of cases have to be brought before the Courts, and these cases have to be appealed in sufficient numbers to enable the crystallisation of flexible, reasonable and reliable standards as to the scope of the duty of care in different case groups (i.e. categories of cases) in case law. Even in Germany, a Member State with an efficient and comparatively 'inexpensive' court system, over-expansive tendencies in the case law of the lower courts on secondary liability are only periodically 'corrected' by the Federal Court of Justice.

Notwithstanding these problems, a conceivable alternative, i.e. to attempt to fix the necessary standard by way of more or less specific statutory rules, cannot be recommended at present. Under the present conditions of informational uncertainty, in particular as to the potential present and future uses of new business models on the Internet as well as in relation to the future development of the technological possibilities of controlling and filtering content, any such attempt would necessarily fail to fairly balance the interests prospectively involved. Other alternatives which have been suggested in the international debate include the proposal for a more prominent role for industry self-regulation initiatives - possibly leading to the development of an industry standard with regard to necessary (and sufficient) preventive measures, particularly in the field of ISP liability. However, undoubtedly, self-regulation also has certain drawbacks as any such initiative would necessarily tend to develop standards which would promote the needs of the institutionally represented interests in the field, i.e. the interests of commercial ISPs and right holders respectively. However, private homepage creators, internet account holders and other groups of persons who are increasingly confronted with claims based upon secondary liability for IP infringements by third parties would certainly not profit from the development of such standards. Thus, absent a statutory framework for such initiatives, and therefore only legally limited by the competition law rules of the Treaty, such initiatives would probably not lead to a fair balancing of all the interests involved in the main categories of secondary liability cases.

The preceding analysis of the present situation with regard to secondary liability rules and future tendencies in that area of IP in the different Member States can also be summarised and restated in light of a (slightly re-formulated) leading question for this paper, i.e. do we need common principles for secondary liability? Indeed, this leads to a particularly interesting result in the field of secondary liability for IP infringements. Namely, while the rules on secondary liability (including their potential legal consequences) differ remarkably throughout the various Member States, a minimum common principle of secondary liability in the sense of a common general direction in assessing secondary liability cases can be identified in the law of most Member States as well as in European law. This common general direction is characterised by the flexible weighing 
of certain relevant factors, such as the violation of a reasonable (or proportionate) duty of care to prevent infringements, the particular role and function of the alleged secondary infringer, the practical need of the right holder to be able to file an action against the secondary infringer and other factors. This flexible system of factors leaves considerable leeway for the courts to specify reasonable and balanced solutions for certain categories of cases. However, given that due to several factors (such as, inter alia, procedural law, the cost of legal proceedings and the size of a Member State) there will be many Member States where the number of cases brought before the courts is simply insufficient to crystallise a standard of reasonable preventive measures for different categories of cases with the necessary degree of legal certainty, indeed, the development of a minimum framework of certain common European principles might play an important role as an overarching structural orientation for the necessarily selective case law, particularly in smaller Member States. Thus, a European system of common principles could ideally establish certain structural elements for the assessment of secondary liability in IP cases: elements of such principles could comprise the listing of certain relevant assessment factors, such as, inter alia, the role and function of the alleged secondary infringer (active or neutral), the degree of control as to the allegedly infringing content and the relevance of the right holder's specific need for an action against the secondary infringer in certain categories of cases (according to the principle of cheapest cost-avoider). Moreover, it would certainly have to be discussed whether the establishment of non-compliance with a reasonable (or proportionate) duty of care to prevent direct infringements, represents a common central element of civil law secondary liability for direct IP infringements throughout the Member States. If the element of a reasonable duty of care could indeed be identified as a common denominator in the laws of most European Member States, this element should certainly be specified in prospective common principles of secondary liability by providing relevant assessment factors for the flexible adjustment of the standard of reasonableness (or proportionality) for certain categories of cases.

As a matter of course, the crucial issue of whether a two-tiered solution - distinguishing between actions on the basis of contributory infringement (including damages) and actions on the basis of secondary 'interferer' liability (limited to injunctions) - or a unitary concept of secondary liability (including injunctions and damages) should be preferred in future European law will also have to be discussed on the European level. However, a common European answer to that crucial structural question will not be easy to achieve, and will indeed already pave the way for the design of common European rules on secondary liability. Therefore, the development of common principles of secondary liability in the sense of generally discussing the future role of a reasonable duty of care with regard to necessary preventive measures in secondary liability cases, and the relevant assessment factors for adjusting the scope of such a duty of care in 
a balanced and proportionate way, should arguably even precede the structural decision of whether and to which extent damages should be granted in secondary liability cases.

In conclusion, from this author's point of view the development of a reasonable (or proportionate) standard of preventive duties of care for certain categories of secondary liability in different Member States' case law is the only viable alternative to develop reasonable (or proportionate) standards of civil law secondary liability under conditions of informational uncertainty. However, given the fact that - in particular in smaller Member States - the necessary preconditions for the crystallisation of such standards in case law - namely a sufficient number of cases - are only partially fulfilled, a system of structural guidance in the sense of a minimum framework of relevant factors for 'channelling' the general direction of this case law seems necessary. Within such a general framework, the further specification of common standards in this field could develop in Member States' case law, thus ideally even allowing certain leeway for a competition between different case law standards which should eventually result in an increasingly specific common standard. Against this background, the development of common European principles of secondary liability (on the basis of the minimum common nucleus of the most recent ECJ's judgments in the field, in particular the judgment in L'Oréal v eBay) would thus indeed be a practically relevant and highly valuable task for common European academic research. Such an initiative might be even more urgently needed on an international scale. 


\title{
Limitations and Exceptions: Towards a European "Fair Use" Doctrine?
}

\author{
Jean-Luc Piotraut
}

\section{Introduction}

In recent years, American courts have held that Google's use of copyrightprotected photographs in a smaller condensed form and in low resolution, as part of the search results generated by the Google image search service, is fair use. ${ }^{1}$ Those courts have, accordingly, ruled in Google's favour. A number of European courts, especially in Belgium, ${ }^{2}$ France ${ }^{3}$ and Germany, ${ }^{4}$ on the contrary, have considered such use of a third-party's articles or photographs to be an infringement of domestic copyright law.

These cases illustrate the current international divergence in approaches to the limitations and exceptions to IP rights, especially in the case of copyright. In Europe, most IP laws enumerate specific limitations and exceptions. In contrast to such a closed system, which seems reasonable for countries with different legal traditions, ${ }^{5}$ US law contains both specific exemptions and a general residuary "fair use" provision, designed to cover specific cases of worthy, unauthorized uses that do not fall comfortably within any of the specific statutory exemptions. This general exemption permits a degree of unauthorized copying or exploiting of products or services, which are protected by IP rights. ${ }^{6}$

${ }^{1}$ For instance in the Perfect 10 v. Google case, 487 F.3d 701 (9th Cir 2007).

2 See Brussels Court of First Instance, No. 06/10.928/C, 13 February 2007, Google Inc. v SCRL Copiepresse, available (in English) at: http://www.copiepresse.be/13-02-07-juge ment-en.pdf.

${ }^{3}$ See Paris Court of First Instance, $3^{\text {rd }}$ Ch., $1^{\text {st }}$ Sect., 20 May 2008, SAIF v Google, available (in French) at: www.foruminternet.org/specialistes/veille-juridique/jurisprudence/ IMG/pdf/tgi-par20080520.pdf.

${ }^{4}$ See, for instance, BGH GRUR 2010, 628, partly overruling OLG Jena MMR 2008, 408, full text (in German) available at: http://www.linksandlaw.de/urteil228-olg-thumbnails-urteil.htm; (although the case has been appealed to the BGH) and LG Hamburg MMR 2009, 55, full text (in German) at: http://www.linksandlaw.de/urteil247-vorschaubilder-rechtswidrig. htm.

5 Sirinelli, Exceptions and Limits to Copyright and Neighbouring Rights, in WIPO Workshop on Implementation Issues of the WCT and the WPPT, Geneva, 7-8 December 1999, pp. 41-42.

${ }^{6}$ In Europe, the UK and Ireland hold an intermediate position: as common law coun- 
Because of these divergent approaches, scholars and IP right holders have called for both an international ${ }^{7}$ and a European fair use provision, ${ }^{8}$ given that the exceptional references to "fair use" in international treaties actually relate to a very specific context. ${ }^{9}$ As a matter of fact, establishing an international "fair use" exception would not be an easy task: "given the ideological divergences between European and American intellectual property systems, it would be infeasible to develop a fair use doctrine that could satisfy the goals of each while remaining consistent with their underlying philosophical premises." ${ }^{10} \mathrm{I}$ doubt the passage of such a doctrine would prove much easier at the European level.

Generally speaking, the development of common principles of European IP law cannot avoid addressing the limitations and exceptions issue. In fact, the ultimate efficiency of harmonization relies on this very issue: ${ }^{11}$ it would be no use harmonizing the contents of IP rights without harmonizing their limitations and exceptions as well. ${ }^{12}$ This issue has been addressed through a number of EU Directives relating to trade marks, design, topographies, biotechnology, copyright and copyright-related rights. A common European approach to limitations and exceptions also had to be found on the occasion of the passage of $\mathrm{EU}$

tries, they have a "fair dealing" doctrine of limitations and exceptions to copyright, which, like "fair use", is a defence against an action for infringement of an exclusive right of copyright. However, whereas the list of enumerated examples of "fair use" contained in the US Copyright Act, is illustrative and not exhaustive, the defence of "fair dealing" is only available to a defendant who can show that his dealing falls within one of the purposes specifically enumerated in the Copyright Act (see Bently/Sherman, Intellectual Property Law, $2^{\text {nd }}$ ed. (2004), p. 193).

7 See especially Okediji, Toward an International Fair Use Doctrine, 39 Columbia J. Transnat'l L. 75 (2000) and Engle, When is Fair Use Fair?: A Comparison of E.U. and U.S. Intellectual Property Law, 15 Transnat'l Lawyer, 187 (2002) (the latter suggesting the extension to the international arena of an amended version of a "fair use" doctrine which would incorporate moral rights).

8 See for instance the Gowers Review of Intellectual Property (2006), available at: http:// www.hm-treasury.gov.uk/d/pbr06_gowers_report_755.pdf, as well as Geiger, The Role of the Three-Step Test in the Adaptation of Copyright Law to the Information Society, e-Copyright Bulletin, UNESCO, January-March 2007, available at: http://unesdoc.unesco.org/ images/0015/001578/157848e.pdf.

9 Article 10(1) of the Berne Convention refers to free quotation of a work whereas Article 17 of the TRIPS Agreement refers to the use of a descriptive trade mark.

10 Okediji (supra, note 7), p. 159.

11 See Benabou, Le processus d'harmonisation communautaire du droit d'auteur, JurisClass. Propriété littéraire et artistique, Vol.3, Sect. 1840, p. 27, No 112 (explaining that the exceptions issue is probably the most critical one relating to the effectiveness of harmonization).

12 As an example, Recital 31 of the Information Society (InfoSoc) Directive No. 2001/29/ EC of 22 May 2001 states: “(...) Existing differences in the exceptions and limitations to certain restricted acts have direct negative effects on the functioning of the internal market of copyright and related rights. Such differences could well become more pronounced in view of the further development of trans-border exploitation of works and cross-border activities. In order to ensure the proper functioning of the internal market, such exceptions and limitations should be defined more harmoniously (...)." 
Regulations establishing Community IP rights (such as the Community trademark, the Community design right, and the Community plant variety right).

Turning to semantic issues, one might theoretically distinguish between "limitations" and "exceptions", the former meaning no privilege and no control at all for the IP right holder, whilst the latter allows for a more extensive acceptation, so that it is possible that compensation or remuneration might have to be paid to the IP right holder. ${ }^{13}$ Now, especially in an international context, limitations and exceptions should be considered synonymous, or at least equivalent. ${ }^{14}$

As far as limitations and exceptions to IP rights in the European context are concerned, could there be an evolution towards a European "fair use" doctrine? This appears to be a rather controversial question: one cannot deny the current emergence of a common European approach, but, on the other hand, I am not sure that such a thing as a European "fair use" doctrine could actually exist.

\section{The Indisputable Emergence of a Common European Approach to Limitations and Exceptions}

In addition to the gradual convergence of European solutions to the problem of IP rights, limitations and exceptions set out in Regulations and Directives, the ECJ has set forth two specific 'Europeanised' judicial limitations on the basis of EU policies (although they have later been expressly included in a number of IPrelated EC Directives and Regulations): on the ground of the free movement of goods policy, the European exhaustion of IP rights doctrine and, on the ground of the free competition policy, judicial compulsory licences. The exhaustion of rights means that a product lawfully manufactured and marketed in a Member State, where it is protected by an IP right, is normally allowed to circulate freely in the whole EU territory. In the Magill case ${ }^{15}$, the ECJ provided for a judicial limitation to IP rights, in the form of a compulsory licence, with a view to punishing the abuse of a dominant position held by an IP right holder.

13 See, for instance, Sirinelli (supra, note 7), p. 2.

${ }^{14}$ For instance, "exceptions", which is used in the Belgian Copyright Act, appears in the Software Directive and in the Database Directive, while "limitations", which is used in the German Copyright Act, appears in a number of EU Acts, such as the Trade Mark, Design, and Rental Directives, plus the Community Trademark, Design, and Plant Variety Regulations. This may explain why the InfoSoc Directive reads: "exceptions and limitations". Besides, the Community Plant Variety Regulation, as well as the Rental and Biotechnology Directives also happen to employ the word "derogations".

15 Joined cases C-241/91P and C-242/91P, Radio Telefis Eireann (RTE) and Independent Television Publication Ltd (ITP) v. Commission, [1995] ECR I-743. 
In any case, considering the various limitations and exceptions provisions contained in the EC Directives and Regulations, plus the numerous judgments about such provisions by the ECJ, a common approach has undeniably been emerging in Europe in relation to the basis for statutory limitations and exceptions. Nonetheless, the ongoing European harmonization is not yet complete due to the persistence of different types of statutory limitations and exceptions.

\section{An emerging common approach to the basis for statutory limitations and exceptions}

The ongoing harmonization of statutory limitations and exceptions in Europe is undeniable despite the fact that most are optional: firstly, because EU Member States are not empowered to establish additional limitations or exceptions and, secondly, because, in implementing Directives in their national legislation, some Member States appear to have admitted limitations and exceptions which already exist in other European countries. ${ }^{16}$

The purposes of the current limitations and exceptions to IP rights in Europe can be brought together in three categories, loosely drawn from Prof. $\mathrm{Hu}$ genboltz's distinction on copyright limitations and exceptions: ${ }^{17}$ technical and practical considerations, fundamental rights and freedoms, public interest or security.

\section{a) Technical and practical considerations}

A first practical consideration relates to private use. This exception is mentioned in many EC Directives and Regulations. ${ }^{18}$ In addition, notwithstanding the absence of a prescribed harmonization of national patent laws on this issue, a similar private use exception is admitted in most national laws, ${ }^{19}$ notably in France, ${ }^{20}$ Germany, ${ }^{21}$ and the UK. ${ }^{22}$

Practical considerations have also led to the intended use of the purchased product or service being set outside of the exclusive right. The unauthorised use

16 Such as France did in 2006, when the InfoSoc Directive was introduced in the French legislation.

${ }_{17}$ Hugenholtz (ed.), The future of copyright in a digital environment. Proceedings of the Royal Academy Colloquium organised by the Royal Netherlands Academy of Sciences (KNAW) and the Institute for Information Law (Amsterdam, 6-7 July 1995) (1996), p. 94.

18 The private use exception can be found in the Directives on design, topography, software (as to back up copies), rental right, database, as well as in the InfoSoc Directive. It is also mentioned in the Community Design and Community Plant Variety Regulations.

${ }^{19}$ Such private use exception is consistent with the one contained in the Plant Variety Rights Regulation.

${ }^{20}$ See Art. L.613-5(a) of the Code de la propriété intellectuelle.

${ }^{21}$ See $\$ 11(1)$ of the Patentgesetz.

22 See Sec. 60(5)(a) of the Patents Act. 
of a third party's trade mark would therefore be lawful "where it is necessary to indicate the intended purpose of a product or service, in particular as accessories or spare parts." 23 A similar solution has been adopted in regard to the use of plant variety rights for propagating purposes on the buyer's own farm, 24 " decompilation" or error correction of a computer program, ${ }^{25}$ as well as acts which are "necessary for the purposes of access to the contents of the databases and normal use of the contents by the lawful user." 26

Lastly, technical considerations might underlie accessory, incidental, trifling, or prior use exceptions. Ephemeral recordings by broadcasting organisations, ${ }^{27}$ uses for the demonstration or repair of equipment, ${ }^{28}$ as well as uses in cases of minor importance ${ }^{29}$ would accordingly not result in IP right infringement. Prior use exceptions have also been established in the field of trademarks, ${ }^{30}$ designs, ${ }^{31}$ and patents. ${ }^{32}$

\section{b) Fundamental rights and freedoms}

As a fundamental right, freedom of expression or information constitutes a limitation or exception to IP rights. A number of unauthorised uses would therefore be allowed pursuant to this freedom, such as use of one's own "name or address" in the course of trade notwithstanding the existence of a protected trade mark, ${ }^{33}$ use of a work for the purposes of reporting current events, ${ }^{34}$ criticism,

${ }^{23}$ Art. 6(1)(c) of the Trade Mark Directive and 12(c) of the Community Trade Mark Regulation.

${ }^{24}$ Art.14 of the Community Plant Variety Regulation.

${ }^{25}$ Art. 6 and 5(1) of the Software Directive.

26 Art. 6(1) of the Database Directive.

27 Art. 10(1)(c) of the Rental Directive and 5(2)(d) of the InfoSoc Directive.

28 Art. 13(2)(b) and (c) of the Design Directive, 20(2)(b) and (c) of the Design Regulation, as well as 5(3)(l) of the InfoSoc Directive.

${ }_{29}$ Art. 5(3)(o) of the InfoSoc Directive. In line with Art. 5ter of the Paris Convention as regards patents, Art. 13(2) of the Design Directive and 20(2)(a) of the Community Design Regulation provide an exception for devices of vessels, aircrafts or land vehicles which would temporarily oraccidentally enter the EU territory.

30 Art. 6(2) of the Trade Mark Directive.

31 Art. 22 of the Community Design Regulation.

32 Although there is no Community harmonization on this issue (see e.g. Osterborg, Towards a Harmonized Prior User Right within the Common Market Patent System, 12 IIC 447 (1981)), a number of European countries have included such right in their legislative systems (this is permitted pursuant to Art. 4(B) of the Paris Convention). However, the German Patentgesetz, $\$ 12(1)$, and the British Patents Act, Section 64(1), contain a real prior user right, whereas French law encompasses a prior possession exception (Article L.613-7(1) of the Code de la propriété intellectuelle) on the basis, not of a prior use, but of the mere knowledge of the patented technology.

33 Art. 6(1)(a) of the Trade Mark Directive and 12(a) of the Community Trade Mark Regulation.

${ }^{34}$ Art. 10(1)(b) of the Rental Directive and 5(3)(c) of the InfoSoc Directive. 
review, parody or advertising for art works, ${ }^{35}$ as well as use of works "of architecture or sculpture, made to be located permanently in public places". ${ }^{36}$

It could be noted that, contrary to the situation in most EU Member States, UK legislation does not provide for a real parody exception, although English courts might consider parodies to be non-infringing, especially on the basis of the requirement of freedom of expression guaranteed by Article 10(1) of the European Convention on Human Rights. ${ }^{37}$

Fundamental rights and freedoms can also extend to the areas of teaching, scholarship, or research, which should not be allowed to be hindered by IP rights. As a result, a number of Directives include an exception in the case of use for the purposes of teaching or scientific research ${ }^{38}$, while other EU Acts contain an experimental use exception. ${ }^{39}$ As a matter of fact, notwithstanding the lack of a prescribed harmonisation of national patent laws on this issue, there is a similar experimental use exemption under many national Patents Acts, including those of France ${ }^{40}$, Germany ${ }^{41}$, and the UK. ${ }^{42}$

\section{c) Public interest or security}

There are a number of other exceptions, which are connected with public interest or security; for example, governmental use of a Community design if it is necessary for essential defence or security needs, ${ }^{43}$ use of a work or a database for the purposes of public security or for the purposes of administrative, parliamentary or judicial proceedings, ${ }^{44}$ as well as compulsory licences on the grounds of public interest ${ }^{45}$ or with respect to public health in poor countries. ${ }^{46}$

Public interest, used in a broader sense, is also relevant in the case of exceptions contained in the Information Society Directive, such as the reproduction of a work by libraries, museums, or archives, ${ }^{47}$ use of a work for social or chari-

${ }_{35}$ Art. 5(3)(d), (j) and (k) of the InfoSoc Directive.

36 Art. 5(3)(h) of the InfoSoc Directive.

37 See Cornish/Llewelyn, Intellectual Property: Patents, Copyright, Trade Marks and Allied Rights, $5^{\text {th }}$ ed. (2003), p. 425 , note 39.

${ }_{38}$ Art. 5(3) of the Topography Directive, 10(1)(d) of the Rental Directive, 6(2)(b) and 9(b) of the Database Directive, as well as Art. 5(3)(a) of the Information Society Directive.

39 Art. 13(1)(c) of the Design Directive, 20(1)(c) of the Community Design Regulation, 15(b) and(c) of the Community Plant Variety Regulation, as well as Art. 5(3) of the Software Directive (although the latter only provides for an "authorization to observe, study or test").

40 See Art. L. 613-5(1)(b) of the Code de la propriété intellectuelle.

${ }^{41}$ See Art. 11(2) of the Patentgesetz.

${ }^{42}$ See Sec. 60(5)(b) of the Patents Act.

43 Art. 23 of the Community Design Regulation.

${ }_{44}$ Art. 6(2)(c) of the Database Directive and 5(3)(e) of the InfoSoc Directive.

45 Art. 29 of the Community Plant Variety Regulation.

${ }^{46}$ See Regulation (EC) No 816/2006 of 17 May 2006 on compulsory licensing of patents relating to the manufacture of pharmaceutical products for export to countries with public health problems.

47 Art. 5(2)(c). 
table purposes, for instance, use for the benefit of the handicapped, ${ }^{48}$ for religious or official celebrations, ${ }^{49}$ reproductions of broadcasts by social institutions pursuing non-commercial purposes (such as hospitals or prisons $)^{50}$ on the condition that right holders receive fair compensation; as well as the "use of an artistic work in the form of a building or a drawing or plan of a building for the purposes of reconstructing the building." 51

\section{A harmonization still in the making, considering the types of statutory limitations and exceptions}

The European harmonization of IP rights limitations and exceptions happened to be based on the adherence of the Member States to international treaties. For example, with respect to copyright-related rights, almost all EU countries adhere to the 1961 Rome Convention for the Protection of Performers, Producers of Phonograms and Broadcasting Organisations, which allows for exceptions to the above-mentioned rights in national laws in the case of private use; the use of short excerpts in connection with the reporting of current events; ephemeral fixation by a broadcasting organization by means of its own facilities and for its own broadcasts; use solely for the purpose of teaching or scientific research, ${ }^{52}$ and in any other situations $s^{53}$ in which national law provides exceptions to copyright in the case of literary and artistic works. ${ }^{54}$

However, as far as limitations and exceptions are concerned, most of the European harmonization results from EC Directives (and occasionally, EC Regulations). Considering the types of statutory limitations or exceptions included in those EC Acts, full harmonization is not authorized: the remaining differences relate to the leeway enjoyed by EU Member States on the one hand, and the features of the particular limitations and exceptions on the other hand.

\section{a) EU Member States' leeway}

The Member States' leeway when it comes to passing limitations and exceptions to IP rights in their national law varies depending on the types of provisions contained in the EU Acts.

Firstly, IP-related Directives often contain necessary limitations or exceptions that Member States have to implement into their national law, without any

\footnotetext{
48 Art. 5(3)(b).

49 Art. 5(3)(g).

50 Art. 5(2)(e).

51 Art. 5(3)(m)

52 Art. 15(1).

53 Except for compulsory licences that would be incompatible with the Berne Convention.

54 Art. 15(2).
} 
elbowroom. This is notably the case for the private use of software ${ }^{55}$ or design, ${ }^{56}$ the use of a computer program, ${ }^{57}$ topography ${ }^{58}$ or design ${ }^{59}$ for teaching or research, the use for the intended purposes of the purchased product with respect to a trade mark, ${ }^{60}$ software,${ }^{61}$ database,${ }^{62}$ topography ${ }^{63}$ or biotechnological invention, ${ }^{64}$ as well as the accessory, incidental or trifling use of a design ${ }^{65}$ or work. ${ }^{66}$ Similarly, EU Member States usually have no leeway at all in relation to limitations and exceptions to the EC Regulation-based Community IP rights, which are solely subject to European law. ${ }^{67}$

Secondly, EC Directives can include optional limitations or exceptions, which means that it is up to Member States to decide whether or not they would implement such limitations or exceptions in their national laws. ${ }^{68}$ Examples of

${ }_{55}$ Art. 5(2) of the Software Directive (with respect to back up copies).

${ }^{56}$ Art. 13(1)(a) of the Design Directive.

57 Art. 5(3) and 6 of the Software Directive.

58 Art. 5(3) of the Topography Directive.

${ }^{59}$ Art. 13(1)(b) and (c) of the Design Directive.

60 Art. 6(1) of the Trade Mark Directive (use to indicate the intended purpose of a product or service, in particular as accessories or spare parts).

61 Art. 5(1) of the Software Directive.

${ }^{62}$ Art. 8 of the Database Directive.

${ }^{63}$ Art. 5(6) of the Topography Directive (provided that the buyer "does not know, or has no reasonable grounds to believe, that the product is protected").

${ }^{64}$ Art. 11(1) of the Biotechnology Directive.

${ }^{65}$ Art.13(2)(a) of the Design Directive (vehicles temporarily or accidentally entering the territory).

${ }^{66}$ Art. 5(1) of the InfoSoc Directive (transient or incidental copying as part of a network transmission or legal use).

67 This would apply to limitations on the effects of a Community trade mark (Art. 12 of the Community Trade Mark Regulation), a Community plant variety right (Art. 15, 18, and 29 of the Community Plant Variety Regulation), and a Community Design (Art. 20 and 22 of the Community Design Regulation, although in the case of Government use, Art. 23 encompasses a conditional limitation: "the use is necessary for essential defence or security needs"). But the EU Member States have a limited room for movement in relation to the Pharmaceutical Patents Compulsory Licensing Regulation (EC) No 816/2006: while they are required to implement compulsory licences for export with respect to public health in poor countries, it is up to them whether or not to prescribe formal or administrative requirements, such as "rules on the language of the application, the form to be used, the identification of the patent(s) and/ or supplementary protection certificate(s)" (Recital 14), to process applications for (Art.6(1)) and to grant such licences (Art. 1), as well as to review and possibly terminate such licences (Art. 16).

68 The Biotechnology Directive and the Pharmaceutical Patents Compulsory Licensing Regulation similarly include a limitation which is somewhere between a necessary and an optional requirement: on the one hand, they both lay down a compulsory derogation to the exclusive patent rights, i.e. the use by a farmer of certain patented material for the purposes of pursuing his business (Art. 11(2) of the Biotechnology Directive) and the manufacture of pharmaceutical patented products (Art. 1 of the Pharmaceutical Patents Compulsory Licensing Regulation). On the other hand, those EU Acts both leave Member States some room in relation to their implementation: Art. 11(3) of the Biotechnology Directive specifies: "The ex- 
such situations include almost all of the derogations provided for in the Rental Directive and the Information Society Directive ${ }^{69}$ as well as the private reproduction of a protected chip topography for non-commercial aims. ${ }^{70} \mathrm{As}$ explained by Prof. Valérie-Laure Benabou, neither the optional character of the exceptions nor their significant number should lead to the conclusion that European harmonization has failed; ${ }^{71}$ on the contrary, such optional provisions have played a great part in bringing national IP laws in Europe - especially with respect to limitations and exceptions - closer to each other.

Thirdly, notwithstanding the absence of prescribed harmonization on certain issues, EU Member States have in fact passed similar limitation or exception provisions in their national legislation, even though it is unclear whether those similarities are fortuitous or the result of a voluntary attempt. It seems, for instance, that almost all European patent laws contain both a private use exception and a research exception, despite the fact that neither of these are required under International treaties or EC Directives.

\section{b) Features of the limitations and exceptions}

As regards the duration issue, most limitations or exceptions to European IP rights are permanent ones: those contained in an EC Regulation are applicable as soon as the Regulation itself comes into force and as long as it subsists, while those included in a Directive have to be brought into force by the Member States, with the Directive itself, within the allotted time (often 3 years) and shall remain applicable as long as the Directive subsists. The Design Directive ${ }^{72}$ and the Community Design Regulation, ${ }^{73}$ however, both encompass transitional provisions relating to limitations and exceptions. When the EC Directive 98/71/ EC on the legal protection of design was adopted, there was no agreement on how to harmonise the spare parts design protection for "complex products". Article 14 of the Directive therefore stipulates that Member States shall maintain their existing laws and may change those provisions only in a way that liberalises the spare parts market. In an attempt to harmonize design protection for spare parts over time, the Commission presented a draft Directive amending the pre-existing one ${ }^{74}$ with respect to the problem of visible spare parts on $14^{\text {th }}$ Sep-

tent and the conditions of the derogation provided for in paragraph 2 shall be determined by national law, regulations and practices", whereas, under the Pharmaceutical Patents Compulsory Licensing Regulation, notwithstanding a number of guidelines, it is up to the national authorities to determine the conditions on which compulsory licences are granted.

${ }^{69}$ See Art. 5 and 10 of the Rental Directive (all the derogations being optional) as well as $5(2)$ and 5(3) of the InfoSoc Directive (only one of the numerous exceptions being obligatory).

70 Art. 5(2) of the Topography Directive.

71 Benabou (supra, note 11), p. 28, No. 114.

72 Art. 14 of the Directive.

${ }^{73}$ Art. 110 of the Regulation.

${ }^{74} \mathrm{COM}$ (2004) 582 final. 
tember 2004. The draft was aimed at liberalising the market for such products with a view to improving competitiveness. It accordingly provides consumers with access to a wider range of spare parts, particularly for car repairs. This is to be achieved by the implementation of the repair clause in national legislation. ${ }^{75}$

While most of the limitations and exceptions, whether necessary or optional, appear to be mandatory, ${ }^{76}$ a few of them depend on conditions. For instance, the following would not constitute an infringement: "the making of a back-up copy by a person having a right to use the computer program (...) insofar as it is necessary for that use", ${ }^{77}$ the unauthorised use of a protected trade mark provided it is made "in accordance with honest practices in industrial or commercial matters" ${ }^{78}$ the unauthorised use of a protected design "provided that such acts are compatible with fair trade practices and not unduly prejudice the normal exploitation of the design and that mention is made of the source", ${ }^{79}$ a teaching or research use ${ }^{80}$ as well as a reproduction by the press in order to provide information ${ }^{81}$ provided that the source is indicated; a private use ${ }^{82}$ or a reproduction by social institutions, such as hospitals or prisons ${ }^{83}$ provided that the right holders receive fair compensation. ${ }^{84}$

Additional limitations and exceptions to IP rights may be desirable, especially in relation to copyright in the digital field. But since European national lawmakers are not allowed to pass additional limitations and exceptions on their own, ${ }^{85}$ it might be up to the European legislator to find a common solution for all EU Member States. Now, would a European "fair use" doctrine constitute the best means to achieve this target?

75 There would be no design protection in a design which is a component part of a complex product and is used to repair that product so as to restore its original appearance. As a result, registered design protection would not be available for spare parts which must match the product as a whole.

${ }^{76}$ For example: private use, use for the purposes of reporting current events, or use for the handicapped.

77 Art. 5(2) of the Software Directive (emphasis added).

78 Art.6(1) of the Trade Mark Directive and 12 of the Community Trade Mark Regulation.

79 Art. 13(1) of the Design Directive and 20(1) of the Community Design Regulation (emphasis added).

80 Art.5(3)(a) of the InfoSoc Directive.

${ }^{81}$ Art.5(3)(c) and (f) of the InfoSoc Directive.

82 Art.5(2)(b) of the InfoSoc Directive.

${ }^{83}$ Art.5(2)(d) of the InfoSoc Directive.

${ }^{84}$ Compulsory licences might be included in those conditional limitations or exceptions.

85 Pursuant to Art. 5 of the InfoSoc Directive. 


\section{Could There Actually Be Such a Thing as a European "Fair Use" Doctrine?}

"Fair use" is a general defence under US copyright law. ${ }^{86}$ Thus, in the field of IP and copyright in particular, there will be no infringement each time the unauthorized use of a protected product or service is made in a reasonable manner and is therefore considered "fair". Although the 1976 US Copyright Act has codified this requirement, ${ }^{87}$ the judicially created doctrine of "fair use" 88 is dynamic in nature, which enables courts to apply it to situations other than those listed in the $\mathrm{Act}^{89}$ and, accordingly, to adapt it to new circumstances: as a result, consumers and users appear to have the advantage of the availability of more limitations and exceptions than presently exist in civil law systems.

The opinion of those who advocate the passage of a "fair use" provision in European law, ${ }^{90}$ is that this flexibility could benefit the current limitations and exceptions to European IP rights by allowing them to more easily adapt to new technologies. However, it seems doubtful that a European "fair use" provision would be both necessary and feasible.

\section{Is a European "fair use" doctrine necessary?}

Given the ideological divergences between European and American IP systems, it has been suggested that an international "fair use" doctrine should be implemented, not as a rule, but as a standard, i.e. only with a view towards "diminishing the range of divergence experienced under the Berne convention." 91 Now, in the European context, considering the current ongoing harmonization of limi-

86 See Bently/Sherman (supra, note 6), p. 193.

87 Pursuant to Sec. 107 of the 1976 Act, the factors to be considered include: $i$ ) the purpose and character of the use, including whether such use is of a commercial nature or is for non-profit educational purposes; $i i)$ the nature of the copyrighted work; iii) the amount and substantiality of the portion used in relation to the copyrighted work as a whole; and $i v$ ) the effect of the use upon the potential market for or value of the copyrighted work. However, those 4 statutory factors are illustrative and not exhaustive, since Sec. 107 was intended to restate the "judicial doctrine of fair use, not to change, narrow, or enlarge it in any way" (H.R. Rep. No. 94-1476, $94^{\text {th }}$ Congress., 2d Sess. 66 (1976).

88 The "fair use" doctrine dates back to the judgment of the Massachusetts Circuit court in 1841 in Folsom v. Marsh (9 F Cas. 342).

89 As soon as the court admits that the use is fair.

90 See e.g. Geiger, Les exceptions au droit d'auteur. Critiques et prospective, in Perspectives d'harmonisation du droit d'auteur en Europe. Rencontres franco-allemandes (2007), pp.349 et seq., esp. 359. See also the British Gowers Review of Intellectual Property (supra, note 8), which recommended pressing for an amendment to the EU InfoSoc Directive that would expressly include transformative "fair use" as one of the recognized exceptions in Europe.

91 Okediji (supra, note 7), p. 159. 
tations and exceptions within the EU, ${ }^{92}$ such an "umbrella" approach appears to be useless.

a) American limitations and exceptions (to copyright) under the "fair use" doctrine often fall under EU specific limitations and exceptions

The Google cases mentioned above exemplify the differences between the United States and Europe in relation to limitation and exception provisions. Nonetheless, even in the absence of a European mechanism of "fair use", one cannot deny that an overall convergence exists on this issue between the IP systems on both sides of the Atlantic. For instance, ${ }^{93}$ in Sony Corp. v. Universal City Studios, Inc. (the Betamax case) ${ }^{94}$ the US Supreme Court held that timeshifting recording accomplished by video tape recorders was "fair use", which proves very close to the European private use exception mentioned in Article 5(2)(b) of the Information Society Directive. Likewise, in Craft v. Kobler, ${ }^{95}$ an American district court admitted that the "fair use" doctrine gives an author the right to quote extracts of a work. A similar limitation for quotations is contained, as an option, in Article 5(3)(d) of the Information Society Directive and is in force in almost all European countries. Lastly, in Sega Enterprise, Ltd. v. Accolade, Inc, ${ }^{96}$ a US circuit court found disassembling a computer program in order to get access to the source code to be "fair use." An identical outcome is likely to arise from the application of Article 5(3) of the Software Directive. ${ }^{97}$

Additionally, the EU's choice to adopt a closed system of specific limitations and exceptions does not rule out the possibility of adaptations of these provisions: for example, Article 12 of the Information Society Directive provides for possible periodical ${ }^{98}$ amendments to its provisions.

\section{b) A "fair use" doctrine has not been developed for all IP rights}

The comprehensive American "fair use" doctrine does not apply to all types of IP rights: it has been constructed in the specific context of copyright law. The "fair dealing" doctrine in British and Irish law similarly appears to be limited to copyright and related rights, as was demonstrated in a 2002 report that ex-

\footnotetext{
92 See supra, Part II: The indisputable emergence of a European common approach to limitations and exceptions.

93 See Poster, The Fair Use Doctrine in the U.S. American Copyright Act and Similar Regulations in the German Law, 5 Chicago-Kent J. Intell. Prop. 146 (2006).

94464 U.S. 417 (1984).

${ }^{95}$ Craft v. Kobler, 667 F. Supp. 120, 128 (S.D.N.Y. 1987).

96 Sega Enter., Ltd. v. Accolade, Inc., 977 F.2d 1510, 1527 (9th Cir. 1992).

97 Besides, in Campbell v. Acuff-Rose Music, Inc. (the "Oh, Pretty Woman" case, 510 U.S. 569 (1994)), the US Supreme Court put parody in the same category as "fair use". The solution is similar to the one provided for in most of the EU Member States under the parody exception, admitted in Art. 5(3)(k) of the InfoSoc Directive.

98 Theoretically, every three years.
} 
pressly mentioned that there was a lack of a well-developed "fair use" type doctrine in the context of British trade mark law. ${ }^{99}$ However, "fair use" might be a defence to a claim of trade mark infringement in the UK since, under Section 10(6) of the Trade Marks Act 1994, it is lawful for a competitor to use the trade mark of a registered proprietor "for the purpose of identifying goods or services as those of the proprietor or a licensee", provided it is "in accordance with honest practices in industrial and commercial matters" unless the use "takes unfair advantage of, or is detrimental to, the distinctive character or repute of the trade mark".

Of course, US law admits a specific trademark "fair use" doctrine on the basis of Section 33(b)(4) of the 1946 Lanham Act. ${ }^{100}$ In this context, a distinction has been made ${ }^{101}$ between classic fair use and nominative fair use. ${ }^{102}$ Classic fair use, set forth in the Lanham Act itself, occurs when a defendant has used the plaintiff's trademark to describe his own products (or their geographic origin), so that the trademark is used in its descriptive sense. On the other hand, nominative fair use is appropriate where a defendant has used the plaintiff's trademark to describe the plaintiff's products (or services), since, in his or her view, it is impossible to refer to those products (or services) without using the trade mark, although this defence is only available if the use will not result in a likelihood of confusion, and provided the mark is not used to capitalize on the rights of the trademark owner. ${ }^{103}$ This legal regime is actually not that different from the European one even though, in Europe, it is not called "fair use".

Moreover, the present US patent system has not developed a "fair use" mechanism either, and American courts have admitted very few "fair use" exemptions in patent law; ${ }^{104}$ besides the specific drug-development exemption ${ }^{105}$ is-

${ }_{99}$ Gangjee, A Scoping Study of Global Trademark Law: The Rise of the ${ }^{\circledR}$, IPAC Report, 3 (2002).

10015 U.S.C. $\$ 1115(\mathrm{~b})(4)$ (admitting as a defence to the unauthorised use of a trademark, that "the use of the name, term, or device charged to be an infringement is a use, otherwise than as a mark, of the party's individual name in his own business, or of the individual name of anyone in privity with such party, or of a term or device which is descriptive of and used fairly and in good faith only to describe the goods or services of such party, or their geographic origin").

101 See Cairns v. Franklin Mint Co., 292 F.3d 1139, 1150-52 (9 $9^{\text {th }}$ Cir. 2002).

102 See e.g. Dinwoodie/Janis, Trademarks and Unfair Competition. Law and Policy (2004), pp.695-713.

${ }^{103}$ In New Kids on the Block v. News Am. Publ'g Inc. (971 F.2d 302 (9th Cir. 1992)), the Court set forth three requirements for nominative fair use to be available to a defendant: "first, the product or service in question must be one not readily identifiable without use of the trademark; second, only so much of the mark or marks may be used as is reasonably necessary to identify the product or service; and third, the user must do nothing that would, in conjunction with the mark, suggest sponsorship or endorsement by the trademark owner."

104 See de Larena, What Copyright Teaches Patent Law About "Fair Use" and Why Universities Are Ignoring the Lesson, 84 Oregon L. Rev. 779 et seq (2005).

105 Codified in 35 U.S.C. $\$ 271(\mathrm{e})$. 
sue, and except in very rare common law-based cases (relating to trifling affairs $\left.{ }^{106}\right)$, US courts have accordingly convicted researchers, mostly university scientists, ${ }^{107}$ on the grounds of patent infringement even though they had used a patented invention just as a "research tool". ${ }^{108}$ Consequently, with a view to addressing problems of market failure, a number of American academics called for the inclusion of a "fair use" provision, modelled on the copyright doctrine, in patent law. ${ }^{109}$

It is somewhat paradoxical that, although "fair use" is a characteristically American legal concept, there is no such thing as a "fair use" in current US patent law, and in particular there is no plain experimental use exemption, whereas European legislation generally provides for such exceptions on the basis of a closed system of specific statutory limitations and exceptions.

\section{c) A "fair use" doctrine involves advantages and disadvantages}

Of course, "fair use" offers courts much flexibility, so that IP law may adapt very easily to the circumstances of each specific case. In contrast, a closed system of specific limitations and exceptions requires lawmakers to enact new laws at regular intervals and such statutes run the risk of being both excessively detailed and quickly becoming outdated or even obsolete. On the other hand, IP aside, legislators have always had the task of adapting law to technological change and social developments and such changes have not caused democratic nations to stop passing new statutes!

Compared to a closed system, a system relying upon a "fair use" doctrine might result in a serious lack of predictability for both right holders and users, since courts' decisions would depend on an assessment of the circumstances of each specific case. Eric Engle has noted that the flexibility of "fair use", "while it permits the courts to decide cases on their individual merits, can also be criticized as capricious, unprincipled, and prone to abuse". ${ }^{110}$

In addition, the "fair use" doctrine seems to be particularly adapted to American copyright law, which occurs to go to extremes with exclusive economic rights; limitations are therefore essential, whether those limitations are internal limitations (such as "fair use") or external limitations (such as competition law). Following the European approach, a "fair use" mechanism would not be neces-

106 This common-law doctrine of "fair use" in patent law stems from a decision by Justice Story in the 1812 case of Whittemore v. Cutter (29 Fed. Cas. 1120 (C.C.D. Mass. 1813)). See Mueller, An Introduction to Patent Law, $2^{\text {nd }}$ ed. (2006), p. 337.

107 Notwithstanding the universities' non-profit status.

108 See notably Madey v. Duke University, 307 F.3d 1351 (Fed. Cir. 2002).

109 O'Rourke, Towards a Doctrine of Fair Use in Patent Law, 100 Columbia L.Rev. 1177 (2000).

110 Engle, (supra, note 7), p. 195. 
sary because IP laws might be seen to balance the interests of all parties (holders and users) more effectively. ${ }^{111}$

\section{Is a European "fair use" doctrine feasible?}

The feasibility of a European "fair use" doctrine is questionable: it is unclear whether such a doctrine accords with both international law requirements and the European legal system.

\section{a) Is "Fair Use" in line with international law requirements?}

Although international IP treaties refer to "fair use" exceptionally"112, most of the international legal framework of IP law "is framed as a set of relatively broad exclusive rights balanced by a narrower and somewhat more specific set of limitations and exceptions thereto."113

In addition, those limitations and exceptions must comply with the internationally accepted three-step test. This test was initially established in $1967^{114}$ in the Berne Convention ${ }^{115}$ with a view to ensuring that member countries could not pass laws which might have abusively restricted authors' rights. Since then, it has been included in a number of international IP treaties ${ }^{116}$ and in various EU Directives relating to IP rights. ${ }^{17}$ The three-step test provides that limitations and exceptions shall only be applied: (i) in certain special cases; (ii) in cases which do not conflict with a normal exploitation of the work or other subjectmatter; and, (iii) in cases, which do not unreasonably prejudice the legitimate interests of the IP right holder.

A potential European "fair use" mechanism should therefore be in line with this test. As to the questionable issue of whether such a "fair use" doctrine is generally in compliance with the three-step test, the breadth and scope of this test has been the subject of (only) one WTO dispute in 2000. ${ }^{118}$ This dispute did

111 It sounds somewhat paradoxical to note that it is some of those who often harshly criticize the US IP system who suggest introducing typically American doctrine into European law!

112 See e.g. Art. 10(1) of the Berne Convention (permitting free quotations of a published work provided that their making is "compatible with fair practice") and Art. 17 of the TRIPS Agreement (admitting limited exceptions to the rights conferred by a trademark, such as fair use of descriptive terms).

113 Wong, "Transformative” User-Generated Content in Copyright Law: Infringing Derivative Works or Fair Use?, 11 Vanderbilt JETL 1101 (2009).

114 On the occasion of the Stockholm Conference, which revised the Berne Convention.

115 Under Art. 9(2) relating to the mere reproduction right in the context of copyright law.

116 Especially the 1996 WCT (Art. 10(1)) and WPPT (Art. 16(2)), as well as the TRIPS Agreement (Art. 13 [copyright], 17 [trademarks], 26(2) [industrial designs], and 30 [patents].

117 Such as the Software Directive (Art. 6(3)), the Rental Directive (Art. 10(3)), the Database Directive (Art. 6(3) and 7(5)), and the Information Society Directive (Art. 5(5).

118 Panel Report, United States - Section 110(5) of the US Copyright Act, WT/DS160/R 
not actually concern "fair use", but rather, it concerned the number of establishments covered by the business exemption found in Section $110(5)(\mathrm{B})$ of the US Copyright Act, ${ }^{119}$ so it remains unclear whether the US doctrine of "fair use" is compliant with the three-step test. As Prof. Ginsburg explains, the Panel decision "may not have made future outcomes any more predictable." ${ }^{120}$ It seems especially hard to predict the finding of the WTO Panel in the event that a "fair use" provision were litigated specifically.

Although the official position of the United States is that the US "fair use" doctrine is consistent with TRIPS, ${ }^{121}$ a number of scholars ${ }^{122}$ think the threestep test may be regarded as a threat to this doctrine which is "framed in such a general and open-ended way". ${ }^{123}$ Accordingly a similar problem might arise with respect to a potential European "fair use" provision: how could such a provision be based on the three-step test, if its American counterpart, on which it would be modelled, were not itself in line with this very test?

In any case, it seems questionable whether the three-step test would constitute a proper legal basis to govern a European "fair use" doctrine.

In 2008, some prominent European IP scholars issued the "Munich Declaration on a balanced interpretation of the 'three-step test' in copyright law."124 This Declaration proposes that, in addition to controlling State autonomy by drafting domestic limitations and exceptions, the three-step test might be incorporated into domestic law and function "as an aid to the interpretation of domestic legislation.” In line with this Declaration, it has also been suggested $^{125}$ that the three-step test could constitute a legal basis for a European

(15 ${ }^{\text {th }}$ of June 2000$)$, available at: http://www.wto.org/english/tratop_e/dispu_e/1234da.pdf Conclusions and recommendations of the report are analyzed in Gaubiac, Exceptions and Limitations to Copyright within the Meaning of Article 13 of TRIPS, available at: http://por tal.unesco.org/culture/en/files/10018/10668256431Gaubiac_E.pdf/Gaubiac\%2BE.pdf

119 The Panel found that the litigated exemption could not be considered a "special case" and, therefore, was in violation of the Berne Convention and, thus, inconsistent under TRIPS.

120 Ginsburg, Toward Supranational Copyright Law? The WTO Panel Decision and the “Three-Step Test” for Copyright Exceptions, RIDA, 2001, issue 187, p. 16.

${ }^{121}$ See Message from the President of the United States transmitting the Uruguay Trade Agreements, Implementing Bill, Statement of Administrative Action, and Required Supporting Statements, H.R. Doc. No. 316, 103d Cong., 2d Sess. (1994).

122 See Ricketson, WIPO Study on Limitations and Exceptions of Copyright and Related Rights in the Digital Environment," SCCR/9/7 Report for the Standing Committee on Copyright and Related Rights, June 2003. See also Okediji (supra, note 7) and Eric Engle (supra, note 7), p. 223 (suggesting, at 190, that the US should, at least partly, abandon its fair use defence).

123 Ricketson (supra, note 122), p. 69.

124 The Declaration, drafted at workshops organized by the Max Planck Institute and Queen Mary, University of London, is available at: http://www.ip.mpg.de/shared/data/pdf/ declaration_three_step_test_final_english.pdf.

125 See notably Geiger, The Role of the Three-Step Test in the Adaptation of Copyright Law to the Information Society (op. cit.) and Senftleben, Copyright, Limitations and the 
"fair use" doctrine: any use of a protected product or service might then be considered lawful, provided it does not conflict with the normal exploitation of the protected product or service, and does not unreasonably prejudice the legitimate interests of the right holder. Such an outcome results from this new reading of the test, ${ }^{126}$ making it "an instrument of flexibility" 127 through the judicial admission of new limitations and exceptions: courts would actually be entitled to carry out proportionality tests, so that conflicting interests of rights holders and users might be taken into account. ${ }^{128}$

However, this "fair use"-oriented interpretation of the test - which the French Cour de cassation has expressly rejected ${ }^{129}$ - is open to a prima facie challenge since the three-step test was "designed to serve as a gauge for assessing the legitimacy of any legislated restriction" 130 on IP rights. Its stated goal is to ensure that WIPO and WTO member countries do not pass laws which may abusively hinder IP rights holders; it has never been intended to be used for admitting new limitations and exceptions. ${ }^{131}$

In addition, although one might legitimately criticize IP rights holders'misuse, I am not sure that the three-step test could constitute a proper basis to govern a European "fair use" doctrine: as Prof. Sirinelli has noted, the three-step test is "not the cure-all" 132 and it "is far from providing harmonization" 133 , especially if it were directly implemented by courts in different countries with divergent legal approaches. A EU mandatory rule to implement such a European "fair use" mechanism would still be required, so that it would be unnecessary to resort to the three-step test.

Three-Step Test - An Analysis of the Three-Step Test in International and EC Copyright Law (2004), as well as L'application du triple test - Vers un système de "fair use" européen?, Propriétés intellectuelles, 2007, vol. 25, p. 45.

126 See Geiger (supra, note 125), p. 18.

127 Ibid., p. 17.

128 Ibid., p. 18.

129 Universal Pictures Video France et al. vs. UFC Que Choisir, Cour de cassation, $1^{\text {st }}$ Civil Chamber, 28 February 2006, available (in French) at: http://www.courdecassation.fr/ jurisprudence_2/premiere_chambre_civile_568/05_16.002_8777.html

${ }_{130}$ Tawfik, International Copyright Law and "Fair Dealing" as a "User Right", UNESCO, e-Copyright Bulletin, April - June 2005, p.10, note 33, available at: http://un esdoc.unesco.org/images/0014/001400/140025e.pdf.

131 Gervais, The TRIPs Agreement: Drafting History and Analysis (Perspectives on Intellectual Property Law) (1998), $\$ 2.71$, p. 89 .

132 Sirinelli, Exceptions and Limits to Copyright and Neighbouring Rights, in WIPO Workshop on Implementation Issues of the WCT and the WPPT, Geneva, 7-8 December 1999, p. 42, available at: http://www.wipo.int/edocs/mdocs/copyright/en/wct_wppt_imp/ wct_wppt_imp_1.pdf.

${ }_{133}$ Ibid. 


\section{b) Is "Fair Use" consistent with the European legal system?}

European IP law is mostly based on specific limitations and exceptions. This is the case firstly with respect to EC Regulations and Directives. Considering, as a typical example, the Information Society Directive, EU Member States are not allowed to pass limitations or exceptions additional to the numerous optional ones listed in that Directive. ${ }^{134}$ Secondly, as far as the national laws of European countries are concerned, the choice of a closed system of specific exceptions to IP rights is consistent with the civil law system in force in the vast majority of the EU Member States. This approach is not questioned in the UK and in Ireland either, notwithstanding the "fair dealing" doctrine applicable pursuant to their Copyright Acts, since this very doctrine relates to quite well-defined cases: ${ }^{135}$ under British copyright law, a "fair dealing" defence is only permitted for the three purposes listed in the $1988 \mathrm{CDPA}^{136}$, i.e. research or private study ${ }^{137}$, criticism or review ${ }^{138}$, or reporting current events ${ }^{139}$, while the 2000 Copyright and Related Rights Act of the Republic of Ireland includes "fair dealing" provisions for the purposes of both research or private studies 140 and criticism or review. ${ }^{141}$ Unlike the related US doctrine of "fair use", "fair dealing" cannot apply to an act, which does not fall within one of these prescribed categories. It seems, as a result, unrealistic to base a potential European "fair use" mechanism on those "fair dealing" regimes.

In addition, in view of the limited powers of the EU (as provided for by EC treaties), one may ask oneself what are the possible legal bases for a European "fair use" doctrine.

Moreover, the American "fair use" defence is rooted in the First Amendment to the US Constitution, which guarantees freedom of speech, including, to a more limited degree, commercial speech. This doctrine is profoundly linked to the common law tradition, which provides courts with much more powers than its civil law counterpart: under a civil law system (which focuses on legal certainty), judges may hardly create a new principle of law. ${ }^{142}$ Considering that the civil law system is in force in a vast majority of the EU Member States, it there-

134 Although, pursuant to Art. 5(3)(o) of the Directive, pre-existent limitations and exceptions might remain in force.

135 See Wong (supra, note 113), pp. 1100 et seq.

136 Although the British courts have construed those specific purposes liberally. See Bently/Sherman (supra, note 6), p. 193.

137 Sec. 29(1).

138 Sec. $30(1)$.

139 Sec. 30(2).

140 Sec. 50.

141 Sec. 51. Note that, pursuant to s. 89 of the Irish Copyright Act, reporting current events constitutes a specific limitation, so that it does not fall under the "fair dealing" defence.

142 Servidio-Delabre, Common Law. Introduction to the English and American systems (2004), p. 77. 
fore seems difficult to implement a real "fair use" doctrine in European law. As Eric Engle points out, "the common law fair use exception is a serious point of conflict between common law and civil law trading partners." 143 If it were implemented, such a doctrine, "which hardly fits in with the continental tradition of copyright, might very well result in worrisome legal uncertainty and therefore plethoric lawsuits." "As4 As a result, a number of EU Member States might be very reluctant to accept "fair use." In addition to the above-mentioned fact that the Information Society Directive provides for possible periodical amendments thereof, the interest of improving European IP law adaptability does not necessarily require the artificial introduction of a "fair use" doctrine: throughout history, all countries (including the civil law countries) have constantly had to adapt their law to the times and progress, although they have not given up their own specific legal approach. ${ }^{145}$

Lastly, "fair use" might not comply with European Court of Human Rights' case law. Irrespective of national courts' case law involving Article 10 of the 1950 European Convention for the Protection of Human Rights and Fundamental Freedoms (viewed as a freedom of expression-based limitation to the rights of copyright holders) ${ }^{146}$, "fair use" might actually relate to the protection of property or possessions under the First Additional Protocol ${ }^{147}$ to the European Convention on Human Rights. Article 1 of the Protocol - Protection of property - provides that "every natural or legal person is entitled to the peaceful enjoyment of his possessions", and that "no one shall be deprived of his possessions except in the public interest..." It appears that "property" or "possessions" has been given a wide meaning in this context, including non-physical property, particularly intellectual property: following the former European Commission of Human Rights' definition of patents in terms of "possessions"148, the European Court of Human Rights has protected both trade marks (on the occasion of the Anheuser-Busch case ${ }^{149}$ about the Budweiser trade mark) and copyright (on the occasion of the Balan case ${ }^{150}$ about a copyrighted photograph) under

${ }^{143}$ Engle (supra, note 7), p. 222.

144 Maurel, Le droit d'auteur dans l'économie de la connaissance: Le nouveau Livre vert de la Commission européenne, une opportunité pour les bibliothèques?, Bull. Bibl. de France, Vol. 54:1, 2009, p. 12 (translation is mine)

145 Civil codes have been amended but they still exist.

146 Article 10 of the Convention establishes a fundamental right to freedom of expression in Europe.

147 Protocol of 20 March 1952.

148 European Commission of Human Rights, Smith Kline and French Laboratories Ltd. v. The Netherlands, 4 October 1990 (Appl. No. 12633/87), Decisions and Reports 1990, Vol.66, p. 70.

149 ECHR (Grand Chamber), Anheuser-Busch Inc. v. Portugal, 11 January 2007, Journal of I.P. Law \& Practice, 2007, Vol. 4, p. 197, comment by Goebel.

150 ECHR (4 $4^{\text {th }}$ Section), Balan v. Moldova, 29 January 2008 (Appl. No. 19247/03), available at: http://www.5nb.com/docs/Balan-v-Moldova\%20ECHR\%20Jan\%202008.pdf. 
Article 1 of the Protocol). As Christophe Geiger has stated, "there is no longer any doubt (...) that the exploitation right is furthermore protected by Article 1 of Protocol 1 of the Convention, which protects property". ${ }^{151}$ A rather imprecise "fair use" doctrine, which could end up harming IP rights holders, might infringe those incorporeal possessions, from now on protected as fundamental human rights in Europe...

\section{Conclusion}

According to Eric Engle, "fair use" is not that fair: it contributes to the favouring of "US IP companies at the expense of their trading partners." 152 The enactment of a European "fair use" doctrine, whether or not based on the three-step test, would not guarantee more fairness in IP law, just as the absence of a "fair use" mechanism does not necessarily result in European IP being unfair. ${ }^{153} \mathrm{Re}-$ turning to the above-mentioned Google thumbnails cases, is it desirable that, by introducing a "fair use" doctrine into European law, European courts overturn their previous decisions in order to rule in Google's favour? Would such an outcome prove much fairer?

Considering its divergent legal traditions, it seems neither desirable nor possible for Europe to do away with its closed system of specific limitations and exceptions. As a matter of fact, as Prof. Sirinelli wrote in relation to the "threestep test", the "fair use" doctrine is probably not a cure-all. The "experimental use" exemption under patent law exemplifies this statement: as already mentioned, European countries generally provide such exception on the basis of a closed system of specific statutory limitations and exceptions, while American law does not, despite the fact that "fair use" is a typically American law concept!

I must admit, however, with a view to adapting IP to new challenges, especially with respect to technological progress and the digital environment, it could be useful to selectively allow courts some more latitude, although such allowance might not necessarily be through a real "fair use" doctrine.

For instance, why not consider a specifically European acceptation of the "fair use" doctrine? Such a potential European "fair use" mechanism could accordingly be limited to a doctrine which is akin to the British or Irish "fair dealing" provisions. It should especially be limited to special cases ${ }^{154}$ and would

151 Geiger, The Constitutional Dimension of Intellectual Property, in Paul L.C. Torremans (ed.), Intellectual Property and Human Rights (enhanced edition of Copyright and Human Rights) (2008), p. 112.

152 Engle (supra, note 7), at 225.

153 See Piotrant, An Authors' Rights-Based Copyright Law: The Fairness and Morality of French and American Law Compared, 24 Cardozo Arts \& Entertainment L.J. 549 (2006).

${ }^{154}$ It would only be permitted for certain statutory purposes listed in EU Directives or 
only supplement a set of specific limitations and exceptions. Such an approach would be more acceptable to civil law EU Member States and, as demonstrated by Prof. Ricketson, would in any case, just like the Australian "fair dealing" provisions ${ }^{155}$, comply with international law requirements, notably the Berne and the TRIPS three-step test.

Regulations, such as private, incidental, or prior use; teaching or research; reporting current events, parody; etc.

155 Ricketson, The three-step test, deemed quantities, libraries and closed exceptions (2002). 



\title{
The Exhaustion of Rights and Common Principles of European Intellectual Property Law
}

\author{
Jens Schovsbo ${ }^{1}$
}

\section{Introduction}

This article discusses the "Common Principles" of the exhaustion of rights. In order to explore a particular legal concept, one must first define the parameters of what one is looking for. For the present purposes, a "Common Principle" is assumed to have the following characteristics:

- it is found in EU-law in its broadest sense;

- it is normative;

- it is "horizontal" and has effects on more than one IPR;

- it is often defined on a higher and more abstract level than a legal "rule"; and

- it is often hidden and has to be deduced (inferred) (normally by law professors).

It is not the purpose of this article to discuss the importance of "Common Principles" in the abstract. I will look upon the issue from the perspective of exhaustion and EU-harmonisation. From this vantage point Common Principles may surface in a number of different ways. Sometimes, Common Principles function as a means of ensuring harmonization. Sometimes, they are better described as the result of harmonisation. There may be a close connection between these two functions: once Common Principles are identified, they may serve as the basis for further harmonization. The existence of these feed back loops illustrates the dynamic nature of harmonization and perhaps even a tendency for harmonization to spread through national legal systems. In this way, Common Principles may be a tool to encourage further harmonization. Unlike more traditional tools for harmonization- directives, regulations etc. - Common Principles are not directly driven by legislators, but rather, by those academics etc. who elucidate them.

Before considering substantive IPR law, it is necessary to make some brief remarks on "harmonization" and "exhaustion".

1 Thanks to my colleague Professor, dr.jur. Henrik Udsen, University of Copenhagen, Centre for Information and Innovation Law for comments on an earlier draft. 


\section{Harmonization}

One often draws a distinction between "negative" and "positive" harmonization. Whereas the focus of the former is on precluding the application of national legislation which constitutes barriers to trade etc., the focus of the latter is on creating common law. The following paragraphs contain examples of both. The primary driving force of negative harmonization is found in what could be called the "the 1.-phase" of the development of exhaustion. The central actor in this phase was the EU Court of Justice ("ECJ") which used Articles 34 and 36 TFEU (ex 28 and 30 of the EC-Treaty) to develop a general principle of exhaustion. This case law identified certain areas (the "existence" of the rights, see more infra) which were left for national legislation to decide on. It was these areas which were then targeted in the "2.-phase" of positive harmonization which relied on directives etc. Both components of negative and positive harmonization are still present, but today the primary development of exhaustion has been taken over by positive harmonization. The role of the ECJ is increasingly to develop the law on the basis of these rules and not directly on the basis of the TFEU.

Harmonization can be described as taking place on different levels. On a low, legal-technical level one finds precise rules which EU-countries are obliged to incorporate in their legislation. On a higher level, the obligation relates to the application of the rule, for instance, in the form of an interpretation which takes into account the "EU-dimension" (such as the "furtherance of intra EU parallel importation"). On a higher level still the obligation could be to use rules outside of their originally designated areas (horizontally) e.g. the use of a rule in the Trade Mark-Directive as a model in a case involving design law where no EU-design rule exists. The last and highest level of harmonization is found at the ideological level and would appear as a Common EU "Feeling” etc. The higher the level the more difficult it would normally be to gauge the content and scope of obligations. Common Principles would typically be on a higher level of harmonization.

The most binding rules are maximum (total) harmonization under which EU-countries are obliged to prescribe the exact level of protection laid out in a directive and can go neither "above" (provide for more protection) nor "below" (less protection). This sort of harmonization sets outs both the floor and the ceiling of protection. A less binding form is minimum harmonization, whereby countries can take further measures if they wish. The distinction between maximum/total harmonization and minimum harmonization can be difficult to draw. As will be shown below, the rules on exhaustion are perceived as being rules of total harmonisation.

Finally, harmonization may be direct or indirect. Indirect harmonization sometimes relies on the use of abstract legal concepts such as "consent" (in the 
exhaustion rules, more infra), or on unclear and value-oriented language such as "protection on a high level". From a legal perspective the problem of this type of harmonization is that its effects may be difficult to foresee. The effect of imprecise - sometimes even deliberately unclear - language could be described as a hidden "time bomb": You do not know when it is going to explode and what effect it will have. ${ }^{2}$ Such rules also push power towards national courts and the ECJ because courts have the ultimate task of giving such concepts content.

\section{Exhaustion}

According to F.-K. Beier "... the principle of exhaustion is nothing more than a figurative expression for the simple legal idea that once genuine goods have been marketed, subsequent distribution should not be impeded by [IPR] actions". ${ }^{3}$

Understood in this way most (all?) legal systems contain "principles" of exhaustion because they all need to develop ways to find out which actions in a chain going from the production of protected goods to the marketing by the first sale and subsequent distribution are covered ("impeded") by the exclusive rights of the right holder. May the first owner, for instance, resell the goods (or does he need the permission of the right holder)? And can the right holder rely on IPR (not just contract law) law to enforce conditions of resale e.g. relating to the price, the territory, or other circumstances (such as the use of vertical distribution systems)?

In order to establish a starting point from which to describe the effects of EU harmonization it is, however, probably best to underline the systematic differences between traditional ways of dealing with these issues. Traditionally, the EU Members have conceptualized “exhaustion” according to two different schools:

- Contract (implied licence). Here Freedom of Contract prevails and the law generally leaves it to the parties (and courts) to define the balance, i.e. to decide whether the buyer of protected goods is allowed to resell, parallel import etc. the goods.

- Principle of Exhaustion: The legislator defines the balance. "Exhaustion" is a statutory limitation to the (statutory) "distribution right" 4 . According

2 An example from copyright could be the notion of a "work" found in the Infosoc.Directive and the way it "exploded" in the ECJ case C-5/08, Infopaq International A/S $v$. Danske Dagblades Forening, (not yet reported). It was arguably a bit of a surprise that the Infosoc.-Directive may have harmonized the most central concept of copyright law. Whether or not this is actually the case remains to be seen - the ECJ will have to speak again on the issue - but a clear risk (or to some, an opportunity) would definitely seem to be present.

3 Beier, Territoriality of Trademark Law and International Trade, 1 IIC, 48, 57 (1970).

${ }^{4}$ Following on from here the term "distribution right" will be used in general to indicate the part of the exclusivity which right holders have to control the "distribution" such as the offering for sale, resale, (re)import, (re)exports, parallel imports and exports, lending, and 
to this rule the right holder automatically looses (some of) his distribution rights with the first instance of marketing.

The labels "contract" and "exhaustion" are arguably not very precise. Obviously, a system based on "contract" would have legal rules and principles in the form of default rules, Similarly, a system based on "principle" would rely on private agreements in the form of contracts between right holders and buyers of goods and would hail the principle of Freedom of Contract and acknowledge the free will of the parties as the foundations of contract law. Labelling, thus, only indentifies certain core values in the various systems. This is, however, important enough to warrant a few further remarks.

The principle of exhaustion stems from German law, where an exhaustion principle ("Erschöpfung") was first developed in patent law by Joseph Kobler around 1900 with the theory of the "Zusammenhang der Benutzungsarten". ${ }^{5}$ According to this principle, the various aspects of exclusivity are interlinked and driven by the purpose of the legislation. Exhaustion limits the distribution right and leaves the right holder with the exclusive right to produce a copy and to put it on the market for the first time. This is a legalistic ("instrumentalist") approach to exhaustion (and indeed to IPR) because the legal design gives the legislator the centre stage and provides for a detailed and elaborate system of rules containing balances and counter-balances. This view does not leave much room for the parties to manoeuvre: "Die Erschöpfungsregel ... is zwingenden Rechts" , and it does not rely upon the will of the parties in order to operate. Nor can it be bent according to the whims of the parties who are normally not free to "contract around" the principle.

Contract was the model traditionally employed in UK law ("implied license"), for example, where according to Cornish and Llewellyn "... the British traditionally adopted the contrary position to 'exhaustion': in principle, subse-

renting etc. Normally, such steps are covered by the IPR exclusivity but one needs to look at the relevant legislation to get the exact picture. To copyright exclusivity relating to dealings with a copy often also include an exclusive right to display the product (which is exhausted). Exhaustion is not relevant to the parts of exclusivity which deal with the making of copies, public performance, etc. save for very special circumstances (e.g. ECJ, case C-337/95, Parfums Christian Dior SA and Parfums Christian Dior BV and Evora BV, [1997] ECR I-6013, (exhaustion based on Art. 34 and 36 of the reproduction right for advertising)) and on this infra at 4.

5 The theory was quickly accepted also in trade mark (RGZ 51, 263 - Mariani) and copyright law (RGZ 63, 394 - Koenigs Kursbuch).

${ }^{6}$ Reimer, Der Erschöpfungsgrundsatz im Urheberrecht und gewerblichen Rechtsschutz unter Berücksichtigung der Rechtsprechung des Europäischen Gerichtshofs, GRUR Int. 1972, 221, 227.

7 It's always very difficult to "box" national legal systems in according to legal families etc. On the issue of "exhaustion", a traditional box labelled "Common law" or even "AngloSaxon law" would often be more misleading than accurate, see more Rothnie, Parallel Imports (1993), which contains in-depth studies of Anglo-Commonwealth Law and US Law. 
quent uses and sales continued to require the patentee's licence" 8.9 In such a legal system both the limitations and the exclusivity provided for by the legislation is weaker and more imprecise than in a system based on "Principles". Instead of having the legislator set the terms of engagement the contract model would leave it more to the parties to establish their relationship including issues such as the right to resell, or parallel import. One could call this a liberalistic approach because the legal design leaves it very much to the parties to define their positions and also to include IPR exclusivity (third party-effect) in the bargain.

The place where the first sale took place has traditionally been very important and most legal systems would distinguish between first sales which took place within or outside the territory covered by the right ("national" v. "international sales”). From the market integrating perspective of the EC/EU the territorial aspect is central. In this regard one distinguishes between the following three situations:

National exhaustion: The distribution right is exhausted only in relation to the country in which the goods have first been marketed by the right holder or with his consent. Marketing in other countries does not exhaust rights. Goods flow freely within the country but parallel importation from other countries can be prevented.

Regional exhaustion: The distribution right is exhausted regarding the (EU-) region in which the goods have first been marketed by the right holder or with his consent. Marketing in other parts of the region also leads to exhaustion. Goods flow freely within the region and parallel importation from one part of the region to other parts cannot be prevented.

Global exhaustion: The distribution right is exhausted by the first marketing of the right holder or with his consent. The geographical place is immaterial. Goods flow freely within the known universe.

8 Cornish/Llewelyn, Intellectual Property, $6^{\text {th }}$ ed. (2007), $\$ 1-49$. The idea of exhaustion met with some resistance in the UK see e.g. White/Kerley, Law of Trade Marks and Trade Names, $12^{\text {th }}$ ed. (1986) who dealt with " the free circulation rule' ... which is also sometimes called the "doctrine of exhaustion of rights" in Chapter 12 on "Community Law" (ibid. $\$ 12.02)$.

9 Traditional French law (droit de suite (destination)) would seem to belong here too, see e.g. Mathély, Le Droit Francais des Signes Distinctifs (1984), pp.322-324 and p. 340 (“... selon le droit français, la protection de la marquee est absolue, et d'application territoriale. Il s'ensuit que le droit n'est pas épuisé par la première mise sure la marché ...” (recognizing, however, exhaustion regarding intra Community trade ("en raison du caractère predominant du droit communautaire”)). See more on French law Castell, L'“épuisement” du droit intellectual an droit allemande, français et communautaire (1989), and for an introduction Krasser, Die Beurteilung von Parallelimporten nach französischem Marken- und Wettbewerbsrecht Bemerkungen zum Fall “Körting“, GRUR Int. 1971, 256-260. The Trademark Directive was implemented in French law in 1991 and this also brought exhaustion to France. Some French commentators did not accept this light-heartedly; see Foyer, Actualité LégislativeDalloz, 1991, 9. Cahier - comm. legis at 64 who describes the exhaustion rules as "inventée par le Reichsgericht en matière de brevets ...” (sic!). 
It is very difficult to identify historical and common starting points especially regarding the law in countries which did not base themselves on "exhaustion" but rather on "contract". In UK law for instance, traditionally the ability to parallel import products produced by a licensee relied on the terms of the contract. In some situations the default position was that parallel importation was possible. In other situations the default position was the opposite. In this system, the place of the first marketing is not a decisive factor and it makes little sense to describe the system as based on a "national" or "global" principle. For trade marks, however, the (most) common regulatory position in European IPR law traditionally favoured a "global" position. The standard argument for this position proceeded the following lines: trade mark law protects the function of the trade mark which is to indicate origin and since that function is protected as long as the goods in question are genuine, the place of first marketing is immaterial. For patents, the common starting point was a national position based on the following Ur-argument: The function of patents is to reward the patent holder by securing for them a monopoly over the profit made from the first marketing effort. Since patents are national in scope and patents in different countries are independent of each other, patent rights exist separately for each country according to the particular marketing efforts made in the individual territories. For copyright, common positions are even more difficult to find. Often, however, much leeway seems to have been given to book publishers, especially in the "big languages", to exercise international price control by limiting parallel imports.

It is important to note that the traditional legal positions on territorial aspects varied between different IPRs and that justifications have been based on a mixture of concerns relating to the underlying purpose of the IPR in question and (especially for copyright and patents) the role of the territory. In the pre$\mathrm{EU}$ (EEC) age the "territory" 10 naturally referred to the territories of the individual national states.

\section{Community Law on Exhaustion}

\section{The Region}

The establishment of the Common Market (EC) and later the EU - in short: regionalisation - represents a paradigm shift for IPRs, changing the name of the game from national optimization to regional optimization. The substitution of national interests with the regional ones as the baseline for IPR has taken place gradually and one way to look upon the development of the exhaustion prin-

10 As pointed out by Beier (supra, note 3), the principle of territoriality does not in itself dictate the formulation of the territorial limitations on exhaustion but leaves it to the national legislator to define the relevant criteria. 
ciple in EU law is to see it as the gradual dismantling of the member states as the centre of IPR protection systems. As part of this development a number of traditional positions have changed: firstly, the establishment of the "Region" "Internal Market" and now "EU") opened a new position between the two traditional extremes of "national" and "global" exhaustion. Secondly, as a result of the influence of the rules on the Free Movement of Goods and the role of the ECJ the emphasis of exhaustion shifted from IPR policies to trade law policies. Thirdly, the issue of exhaustion became identified with the ability to parallel import and this dramatically raised the political stakes and placed the until then rather unknown legal principle of exhaustion in the legal and political spotlight.

In the case of exhaustion, these developments also had an impact on the choice of legislative model.

\section{2. "Contract" or "Principle"?}

As has been described above, national law left the ECJ (and later the EU) legislator with a choice between two models for exhaustion: either "contract" or "exhaustion". The ECJ opted for "the principle of exhaustion" and not "contract" very early on. This model has been followed in later directives, regulations, etc. This choice is hardly surprising given that this approach is well suited for pursuing clear policy goals. In fact, a contract based model would be totally unsuitable for implementing clear policy objectives such as Free Movement of Goods.

A. Obly is therefore correct when he points out that the "driving force behind permitting parallel imports inside the European Union is not trade mark law but the creation of an internal market"11. The point to be made here, however, is that the shift which Obly notes when seen from the perspective of the exhaustion principle, is only a shift in policies - "from IPR to trade" - and not in the legal methodology which is applied. It is precisely this ability to internalize policy goals which is the decisive advantage (in terms of achieving policy objectives) of the legalistic and instrumentalist principle of exhaustion-model compared to the liberalistic contractual model.

\section{Finding Exhaustion in the EU-Treaty}

The starting point for balancing IPR and Treaty rules and principles was given in 1966 by the ECJ in Consten. ${ }^{12}$ According to this decision, the TFEU does not limit the "existence" of rights. It merely affects the "exercise" of those

${ }^{11}$ Obly, Trade Marks and Parallel Imports - Recent Developments in European Law”, 30 IIC 512-530 (1999).

12 ECJ, joined cases 56 and 58-64, Établissements Consten S.à.R.L. and GrundigVerkaufs-GmbH v. Commission of the European Economic Community, ECR English spe- 
rights. ${ }^{13}$ This is a legal "Moment of Zen", in which one is being asked to contemplate whether a right may "exist" if it cannot be "exercised"? Of course it cannot! Despite this obvious flaw, the distinction provides some legal certainty and, therefore, can be used as long as nobody takes it too seriously (which the ECJ does not). For the present discussion, the distinction is important because it links the dealings of private parties with the objectives of the Treaty. This is an instrumentalist way of regarding a contract: the purpose of the contract is not (only) to reflect the will of the parties it is also (and maybe foremost) to realize greater goals. It is submitted that this reasoning is in fact completely in line with traditional IPR thinking. From an IPR perspective the private gains of right holders are thus just a means of achieving the greater benefits associated with dynamic competition (innovation).

The principle of exhaustion was first established in the 1974 Centrafarm decisions. ${ }^{14}$ The issues before the ECJ were whether or not parallel imports to the Netherlands violated patent law (Centrafarm/Sterling Drug) or trade mark law (Centrafarm/Winthrop). In both cases the ECJ found that parallel importing could not be prevented. In both cases the Court based this decision on the principle of exhaustion. In Centrafarm/Wintbrop it phrased the issue in this way (with italics added):

"9 An obstacle to the free movement of goods may arise out of the existence, within a national legislation concerning industrial and commercial property, of provisions laying down that a trade mark owner's right is not exhausted when the product protected by the trade mark is marketed in another member state, with the result that the trade mark owner can prevent importation of the product into his own member state when it has been marketed in another member state.

10 Such an obstacle is not justified when the product has been put onto the market in a legal manner in the member state from which it has been imported, by the trade mark owner himself or with his consent, so that there can be no question of abuse or infringement of the trade mark.

cial edition 299 1966. The case dealt with exhaustion but on the basis of the cartel rule in TFEU Art. 101 (ex Art. 81 ECT). The concrete circumstances - a cartel - made it unnecessary for the Court to address the issue of IPRs specifically.

13 The basic distinction still exists but the language has changed over the years. Instead of referring to the "existence" of the right the Court has been using expressions such as "the essence of the exclusive right" (ECJ, case 16/74, Centrafarm og Adriaan de Peijper mod Winthrop,[1974] ECR 1183, para. 10), "the specific subject matter" (ECJ, case 102/77, HoffmannLa Roche v. Centrafarm, [1978] ECR 1139, para. 7, and also ECJ, case C-200/96, Metronome v. Music Point, [1998] ECR I-1953, para. 14), "the essential function" (ECJ, case 62/79, Coditel v. Ciné Vog, [1980] ECR 881, para. 14), or "the legitimate exercise" (ECJ, case 144/81, Keurkoop v. Nancy Kean Gifts, [1982] ECR 2853, para. 24). The underlying rational is the same: Each type of IPR has a "core" of rights which as a general rule is not influenced by the rules of the Treaty. Within this core rightholders are free to enjoy their rights.

14 ECJ, case 15/74, Centrafarm og Adriaan de Peijper v. Sterling Drug, [1974] ECR 1147 and ECJ, case 16/74, Centrafarm og Adriaan de Peijper v. Winthrop, [1974] ECR 1183. 
11 In fact, if a trade mark owner could prevent the import of protected products marketed by him or with his consent in another member state, he would be able to partition off national markets and thereby restrict trade between member states, in a situation where no such restriction was necessary to guarantee the essence of the exclusive right flowing from the trade mark."

The wording in Centrafarm/Sterling Drug is almost parallel, see, however, para. 11 in that decision:

"Whereas an obstacle to the free movement of goods of this kind may be justified on the ground of protection of industrial property where such protection is invoked against a product coming from a member state where it is not patentable and has been manufactured by third parties without the consent of the patentee and in cases where there exist patents, the original proprietors of which are legally and economically independent, a derogation from the principle of the free movement of goods is not, however, justified where the product has been put onto the market in a legal manner, by the patentee himself or with his consent, in the member state from which it has been imported, in particular in the case of a proprietor of parallel patents".

In the case of patents this ruling was followed by Merck v. Stephar in which the Court explained that the substance of a patent right essentially lies in "according the inventor an exclusive right of first placing the product on the market so as to allow him to obtain the reward for his creative effort"15. On this basis, the ECJ in Pharmon v. Hoechst found that a patent holder can prevent the importation and marketing of products manufactured under a compulsory license because such a measure "deprives the patent proprietor of his right to determine freely the conditions under which he markets his products". ${ }^{16}$ Otherwise, the patent holder would not be able to "protect the substance of his exclusive rights under his patent"17.

Since Centrafarm, the ECJ has affirmed the principle of exhaustion on a number of occasions, based on the same basic argument of "negative" harmonization, that is, that the "exercise" of an IPR to prevent or limit imports of protected goods is contrary to Article 34 TFEU. Such a measure is only allowed by Article 36 TFEU if it pertains to the "existence" of the rights. If the goods have been marketed for the first time within the EU by the right holder or with his consent, there is usually no exemption. The legal position in the EU-parallel imports are permissible except under extraordinary circumstances - is the result of a balancing of interests: the Regional interest in the free movement of goods and the Common Market and the interests of national IPR holders in being rewarded for their efforts in furthering innovation or creativity or promoting fair and undistorted competition. The result of this balancing

15 ECJ, case 187/80 Merck E Co. Inc. v. Stephar BV and Petrus Stephanus Exler, [1981] ECR 2063, para. 9.

16 ECJ, case C-19/84 Pharmon BV v. Hoechst $A G$, [1985] ECR 2281, para. 25.

17 ECJ, case C-19/84 Pharmon BV v. Hoechst AG, [1985] ECR 2281, para. 26. 
does normally not give rise to much doubt. The concern for the free movement of goods is sometimes accompanied by other concerns such as the "question of competition"18, "general principles of Community law" including "the economic and cultural development of the Community" and the "right to property and the freedom to pursue a trade or profession"19, or the "the general principle of non-discrimination" found in the Treaty ${ }^{20}$. In addition to these concerns the $\mathrm{EU}$ and the regional perspective provide the relevant framework for balancing rights and limitations.

\section{EU Rules of Exhaustion}

Similar rules on exhaustion are now found in the directives on trade marks, copyright, and designs. The base line regulation on exhaustion is the Trade Marks -Directive. Article 5 of that Directive contains the exclusive right ("distribution right”) and Article 7 provides for exhaustion as a limitation of the exclusivity provided for:

Article 5: Rights conferred by a trade mark

1. The registered trade mark shall confer on the proprietor exclusive rights therein ...

2. The following, inter alia, may be prohibited ... (b) offering the goods, or putting them on the market; (c) importing or exporting the goods under the sign; (d) using the sign on business papers and in advertising.

Article 7: Exhaustion of the rights conferred by a trade mark

1. The trade mark shall not entitle the proprietor to prohibit its use [i.e. rely on Article 5] in relation to goods which have been put on the market in the Community under that trade mark by the proprietor or with his consent.

2. Paragraph 1 shall not apply where there exist legitimate reasons for the proprietor to oppose further commercialization of the goods, especially where the condition of the goods is changed or impaired after they have been put on the market.

This is the traditional "German" structure of exhaustion: the law provides for a broad distribution right and at the same time for a limitation regarding goods which have been brought onto the market by the right holder or with his consent. The same model is found in some of the Directives on copyright. The wording in these is not completely identical, but the differences would appear to be of no great importance. The newest rule is the one in the Infosoc.-Directive, Article 4(2):

18 ECJ, case 40/70 Sirena S.r.l. v. Eda S.r.l. and others, [1979] ECR 3169, para. 5.

19 ECJ, case C-200/96, Metronome v. Music Point Hokamp, [1998] ECR I-1953, paras. 21-23.

${ }^{20}$ ECJ, joined cases C-92/92 and C-326/92, Phil Collins, [1993] ECR I-5145, para. 27. 
"The distribution right shall not be exhausted within the Community in respect of the original or copies of the work, except where the first sale or other transfer of ownership in the Community of that object is made by the right holder or with his consent." 21

The exhaustion rule is a limitation on the distribution right and therefore relates to dealings with the physical copies of protected works, branded goods, inventions, etc. Phrased in the language of copyright: exhaustion only applies to the distribution right (and any public display right) and not to the reproduction right or the communication to the public-right. Even though this is basic feature of the exhaustion rule it is a little blurred at the edges. In copyright law the Dior case which allowed for some reproduction even of marks protected by copyright for advertising purposes, could be seen as an exception to the assumption that exhaustion does not apply to the reproduction right. Similarly, one could point to the droit de suite 22 or the unwaiveable right to receive "equitable remuneration for rental" 23 as examples of derogations from the rule in the sense that the copyright holder retains these rights even after the sale of a copy. These examples obviously prove that some times exhaustion is broader than one would expect and sometimes it is narrower. In my view it would be wrong, however, to see these examples as "exceptions" to a general rule/principle of exhaustion. The point - in my view - rather, is that the very notion of "exhaustion" is not in itself particularly precise besides some basic parameters and also that one should see exhaustion as a general principle for balancing interests in IPR between right holders and owners of copies and not as a dogma.

${ }^{21}$ See also: Computer Programs-Directive (91/250), Art. 4(c): “Any form of distribution to the public, including the rental, of the original computer program or of copies thereof. The first sale in the Community of a copy of a program by the right holder or with his consent shall exhaust the distribution right within the Community of that copy, with the exception of the right to control further rental of the program or a copy thereof.” Rental and lendingDirective (92/100), Art. 9(2): "The distribution right shall not be exhausted within the Community in respect of an object as referred to in paragraph 1, except where the first sale in the Community of that object is made by the right holder or with his consent." Database-Directive (96/9), Art.5(c): "Any form of distribution to the public of the database or of copies thereof. The first sale in the Community of a copy of the database by the rightholder or with his consent shall exhaust the right to control resale of that copy within the Community".

22 See Directive 2001/84/EC of the European Parliament and of the Council of 27 September 2001 on the resale right for the benefit of the author of an original work of art.

${ }^{23}$ See Directive 2006/115/EC of the European Parliament and of the Council of 12 December 2006 on rental right and lending right and on certain rights related to copyright in the field of intellectual property, Art. 5(2). See also ECJ, case C-61/97, Foreningen af danske Videogramdistributører and Laserdisken, [1998] ECR I-5171, where the Directive was upheld. The limitation was already acknowledged in ECJ, case 158/86, Warner Brothers Inc. and Metronome Video ApS v. Erik Viuff Christiansen, [1988] ECR 2605, where it was found that a national rule which kept a specific right to hire out video-cassettes outside of the exhaustion rule did not constitute a problem vis-à-vis Art. 34 and 36. 
An example of a dogmatic and - in my view - problematic use of the "principle of exhaustion" can be found in the notorious Infosoc.-Directive. In the Preamble it is noted that

"The question of exhaustion does not arise in the case of services and on-line services in particular. This also applies with regard to a material copy of a work or other subjectmatter made by a user of such a service with the consent of the right holder. ... Unlike $\mathrm{CD}-\mathrm{ROM}$ or CD-I, where the intellectual property is incorporated in a material medium, namely an item of goods, every on-line service is in fact an act which should be subject to authorisation where the copyright or related right so provides. (point 29)"

This very sharp distinction between on line and off line transactions can arguably be criticized for placing too much weight on formalities. Instead of basing the rule on the realities of the transactions the rejection is based on the exhaustion principle; "The question of exhaustion does not arise". Such a legal position cannot be inferred from "exhaustion" itself (as the examples above indicate) and the reference to the principle of exhaustion therefore only serve to hide the real reasoning behind what is the apparently impeccable logic of the IPR system.

For the present discussion, the next important point to note is that the leeway granted does not include circumstances in which Market Integration is at stake. The best example of this would seem to be the general acceptance of the the regional principle which can be found in all the rules. In trade mark law this was settled by the pivotal Silhonette decision (more infra). The regional principle is also acknowledged in copyright ${ }^{24}$ and design $\mathrm{law}^{25}$. As seen from a historic perspective the general acceptance of the same territorial principle across all of IPR is novel (more supra at 1.2).

For patents the matter is more complicated. ${ }^{26}$ According to the Preamble of the Proposal for a Council Regulation on the Community patent "the exhaus-

24 Infosoc-Directive, Art. 4(2) and the Preamble point 28: “... This right should not be exhausted in respect of the original or of copies thereof sold by the rightholder or with his consent outside the Community." This reading was affirmed in ECJ case C-479/04, Laserdisken ApS v. Kulturministeriet, [2006] ECR I-8089 and was also assumed by the General Court in case T-198/98, Micro Leader, [1999] ECR II-03989 (the Computer Programs-Directive). The latest decision is ECR, case C-456/06, Peek E Cloppenburg v. Cassina,[2008] ECR I-2731, (noting inter alia. that exhaustion presupposes a transfer of ownership and stressing that that the rules of the Infosoc.-Directives on distribution right and exhaustion should be read in the light of the obligations imposed by WCT and WPPT).

25 Directive 98/71/EC of the European Parliament and of the Council of 13 October 1998 on the legal protection of designs Art. 15.

26 Directive 98/44/EC of the European Parliament and of the Council of 6 July 1998 on the legal protection of biotechnological inventions contains a rule in Art. 10, which should probably be understood as a rule of exhaustion. It is unique, however, in allowing for the propagation or multiplication of biological material placed on the market in the territory of a Member State by the holder of the patent or with his consent, where the multiplication or propagation necessarily results from the application for which the biological material was marketed. 
tion of rights, must follow the same principles as the existing Community legislation with respect to national patents" ${ }^{27}$. Article 10 of the same proposal contains a rule of exhaustion regarding products which have been "put on the market in the Community by the proprietor of the patent or with his consent"28. According to the Commentary "this Article lays down the principle of Community exbaustion. Corresponding rules are included in Article 28 of the Luxembourg Convention and Article 13 of the Regulation on the Community trade mark. (italics added)." The precise meaning of the references to "Community exhaustion" and to "Community trade marks" is not crystal clear. It would seem reasonable, however, to understand it as a reference to the regional principle as laid out in Silhouette (i.e. "mandatory" regional exhaustion which does not allow countries to retain or (re)introduce rules on either national or global exhaustion). What is not clear, however, is whether such a rule should be seen as a codification of an already existing "Common Principle" (based on the Treaty) or whether it would need legislation in order to come into existence. The question is not a very practical one as most countries relied on a national position (supra). As a matter of principle, however, it would seem likely that the ECJ would find regional exhaustion to also apply to patents and that the court would rely on both the rules of the Treaty and on the harmonization efforts in the fields of trade marks, copyright, and design to establish a "Common Principle" to that effect.

\section{Common Principles of Exhaustion}

In the following part I will try to identify a "Common Principle" (as defined above, 1) which directs the application of the rules of exhaustion described supra.

\section{Do Common Principles Exist which Direct the Application of the Rules of Exhaustion Found in EU-Legislation?}

Here I will use trade mark law as an illustration and I will focus my discussion on the criteria in Article 7(1) of the Trade Mark-Directive and in particular on the notion of "consent".

27 Proposal for a Council Regulation on the Community patent COM/2000/0412 final CNS 2000/0177, the Preamble, point 4a.

28 It reads: "The rights conferred by the Community patent shall not extend to acts concerning the product covered by that patent which are carried out within the territories of the Member States after that product has been put on the market in the Community by the proprietor of the patent or with his consent, unless there are legitimate grounds for the proprietor to oppose further commercialisation of the product." 
The starting point for the discussion is given by the ECJ's reasoning in the Silhonette case and the notion of "complete harmonization".

\section{a) Silhouette and "complete harmonization"}

Silhonette concerned the parallel importation of sunglasses from Bulgaria to Austria. Traditionally, Austrian trade mark law had allowed for the importation of "genuine goods" based on a rule of "global exhaustion". The central question was whether this principle could be upheld after the Trade Mark-Directive.

The Court found that Articles 5 to 7 of the Directive must be construed as embodying a complete harmonisation of the rules relating to the rights conferred by a trade mark (para. 25) and that the Directive "cannot be interpreted as leaving it open to the Member States to provide in their domestic law for exhaustion of the rights conferred by a trade mark in respect of products put on the market in non-member countries" (para. 26). Such a reading, it was explained, would be the only interpretation "which is fully capable of ensuring that the purpose of the Directive is achieved, namely to safeguard the functioning of the internal market" (para. 27).

The regional principle was - and to some extend remains - controversial. ${ }^{29}$ For present purposes, however, the most remarkable aspect of the decision is the notion of "complete harmonization". In Silhonette this principle was applied in order to identify the obligation imposed by the Directive on the Member States to further the interests associated with the Internal Market. According to the ECJ, this has both an internal dimension and an external dimension and requires not only the removal of internal barriers but also a common position regarding external borders ("Festung Europa" to some). From this, it followed that: 1) Article 5 and 7 embody a complete harmonization; and 2) the establishment and functioning of the internal market constitute the core values involved when interpreting the rules of the Directive.

On this basis we now turn to the notion of "consent".

29 The criticism from German academia was particularly strong, see notably Beier, Industrial Property and the Free Movement of Goods in the Internal European Market, 21 IIC 131-160 (1990) and v. Gamm, Schwerpunkte des neuen Markenrechts - Referat anlässlich der GRUR-Jahrestagung am 3. 6. 1994, GRUR 1994,775, 778, pointing out that: “... zum Wesen der Marke als solche gehört ... die gemeinschaftsweite Erschöpfung des Rechts nicht”. It is interesting to note that the first proposals for the Directive and Regulation were based on the principle of global exhaustion, e.g. Bulletin, Supl. 5/80 at p. 69 (Regulation) and 15 (Directive). The regional principle was first proposed by the Economic and Social Committee in 1981, OJ C 310, 30 November 1981, p. 22. By 1985 it was part of the Commission's proposal, OJ C 351, 31 December 1985, p. 4. It is exactly the choice of the Exhaustion Principle that made such political decisions possible. 


\section{b) "Consent"}

"Consent" is a core criterion in Article 7 and identifies the circumstances under which exhaustion occurs regarding goods which have not been marketed by a right holder himself but by, e.g., a licensee. It is thus a part of trade mark law; a "fact of law" which needs to be established in order for exhaustion to occur: if no "consent", then no exhaustion. The concept of "consent", however, is also known in traditional contract law where the issue of consent would normally be relevant in establishing whether an obligation exists. To a legal system which bases exhaustion on the contract-model described supra one would often expect the marketing of goods by a licensee to include an "implied consent" from the right holder to the licensee to market the product and from this one would then infer "exhaustion".

The wording of Articles 5 and 7 arguably does not make it very clear how one should understand the concept of "consent". According to one reading, "consent" would be a harmonized concept of trade mark law which should be read according to the rules and principles of the Directive. Such a reading would direct attention away from the parties and their agreement and focus the eyes of the court on Articles 5 and 7. On another reading, "consent" would refer to (national) contract law. This sort of an understanding would direct the court to look for "consent" in the contract or in the behaviour of the parties. It may also be more open to the application of principles of contract law developed in national law ("implied license" etc.). Finally, one could also understand "consent" as implying some intermediate solution according to which "consent" would incorporate a harmonized contract law principle which directs attention towards the will of the parties but does not allow for the application of nationally developed principles of contract law. It is, therefore, submitted that some room of doubt is still left in the choice of interpretation of "exhaustion" in the Directive not only in relation to the literal understanding of "consent" but also as to the framework for understanding it and the relationship between the areas (directly) harmonized by trade mark and adjacent areas such as contract law.

The ECJ has dealt with the issue in a series of cases.

In Sebago ${ }^{30}$ it was established that "consent" relates to each individual item in respect of which exhaustion is pleaded. Importantly, the court also noted that the Directive does not give a direct answer to the question of what is meant by "consent" but that nevertheless "the rights conferred by the trade mark are exhausted only in respect of the individual items of the product which have been put on the market with the proprietor's consent in the territory there defined" (para. 19). On this basis, the ECJ explained that Article 7(1) of the Directive must be interpreted as meaning that "the rights conferred by the trade mark are exhausted only if the products have been put on the market in the Community

30 ECJ, case C-173/98, Sebago and Ancienne Maison Dubois et Fils, [1999] ECR I-4103. 
... and that provision does not leave it open to the Member States to provide in their domestic law for exhaustion of the rights conferred by the trade mark in respect of products put on the market in non-member countries; for there to be consent within the meaning of Article 7(1) of that directive, such consent must relate to each individual item of the product in respect of which exhaustion is pleaded." (para. 22). These remarks are fully in accord with Silhouette and the principle of "complete harmonization". By making this point in relation to "consent", however, the ECJ arguably also pushed trade mark law into the grey area between trade mark law and contract law. The Court does not explain what one should understand by "domestic law". It would be natural to interpret this as referring to uniform "trade mark law" and to infer from this that "consent" should be understood as a trade mark law concept. The decision, however, still left some questions open as to the relationship with contract law: could trade mark law perhaps incorporate national contract law? Or should one disregard contract law?

Some of these issues were settled by Davidoff ${ }^{31}$ in which the English Justice Laddie had asked the ECJ to clarify not only the criteria of consent but also the framework for understanding the concept: is the framework for understanding "consent" (really) trade mark law and not national contract law? The ECJ first remarked that the concept of consent used in Article 7(1) of the Directive must be interpreted uniformly throughout the Community legal order (para. 37) and that it follows from Silhonette that Articles 5 to 7 of the Directive embody a complete harmonization (para. 39). This was old news. Then the ECJ continued:

"40. Article 5 of the Directive confers on the trade mark proprietor exclusive rights entitling him, inter alia, to prevent all third parties not having his consent from importing goods bearing the mark. Article 7(1) contains an exception to that rule in that it provides that the trade mark proprietor's rights are exhausted where goods have been put on the market in the EEA by the proprietor or with his consent.

41. It therefore appears that consent, which is tantamount to the proprietor's renunciation of his exclusive right under Article 5 of the Directive to prevent all third parties from importing goods bearing his trade mark, constitutes the decisive factor in the extinction of that right.

42. If the concept of consent were a matter for the national laws of the Member States, the consequence for trade mark proprietors could be that protection would vary according to the legal system concerned. The objective of the same protection under the legal systems of all the Member States set out in the ninth recital in the preamble to Directive 89/104, where it is described as fundamental, would not be attained.

43. It therefore falls to the Court to supply a uniform interpretation of the concept of consent to the placing of goods on the market within the EEA as referred to in Article 7(1) of the Directive. (italics added)"

31 ECJ, joined cases C-414/99 to C-416/99, Zino Davidoff, [2001] ECR I-8691. 
On this basis, the ECJ also provides concrete guidance on the interpretation of the requirement of consent which "... may be implied, where it follows from facts and circumstances ... which, in the view of the national court, unequivocally demonstrate that the proprietor has renounced his right to oppose placing of the goods on the market within the European Economic Area". In particular, the ECJ rejected the position traditionally taken in UK law, e.g. that implied consent may be inferred from the unconditional marketing of the goods. ${ }^{32}$

Matters were further clarified in Copad. ${ }^{33}$ According to the ECJ, when goods are sold in violation of the clauses listed in Article 8(2) there is no consent regarding Article 7(1) (and thus no exhaustion takes place). These decisions would seem to be in line with the other cases mentioned above: trade mark law is the relevant framework and parties are free to exercise their contractual freedom within the limits prescribed by that law. On this point, one could finally also refer to Peak ${ }^{34}$, according to which exhaustion is triggered by transactions ("sales") "which allows the proprietor to realise the economic value of his trademark" (para. 40). The framework for understanding exhaustion, therefore, is not the perspective of the parties, rather, it is the common good which is the aim of trade mark law. Such an instrumentalist view of the contract is completely in line with the rulings mentioned above.

After these decisions the argument for understanding "consent" is thus:

1) Articles 5 to 7 offer "complete harmonisation";

2) in particular, Article 5 of the directive confers on the trade mark proprietor exclusive rights which entitle him, inter alia, to prevent any third party from importing goods bearing the mark, offering the goods, or putting them on the market or stocking them for these purposes. Article 7(1) contains an exception to that rule, in that it provides that the trade mark proprietor's rights are exhausted where the goods have been put on the market in the EEA by him or with his consent;

3) it is therefore apparent that consent, which is tantamount to the proprietor's renunciation of his exclusive rights within the meaning of Article 5, constitutes the decisive factor in the extinction of those rights and must, therefore, be expressed in such a way that an intention to renounce those rights is unequivocally demonstrated;

4) such an intention will normally be gathered from an express statement of that consent. However, the requirements deriving from the protection of the free movement of goods have led the Court to hold that such a rule can be qualified; and that

32 In a later case the ECJ made it clear that the principles developed in Davidoff are general and thus apply "with no distinction being made in principle depending upon whether marketing first occurred outside the EEA or within it", ECJ, case C-324/08, Makro v. Diesel (not yet reported), para. 28 .

33 ECJ, case C-59/08, Copad SA v. Christian Dior couture not yet reported.

34 ECJ, case C-16/03, Peak Holding AB v. Axolin-Elinor AB, [2004] ECR I-11313. 
5) exhaustion of the exclusive rights can occur, inter alia, when the goods are put on the market by an operator with economic links to the proprietor of the trade mark, for example, a licensee. ${ }^{35}$

Starting from the exclusive right and its limitation the Court, by a string of deductions, thus arrives at a model for understanding "consent". Understood correctly "consent" does not refer to national contract law but to harmonized trade mark law. This doesn't mean that the intentions of the parties to an agreement for the sale of branded goods are not important but their importance must be decided on the basis of the trade mark rules.

\section{c) Conclusion}

Based on the discussion above, it would seem that a Common Principle exists which directs the application of the rules of exhaustion found in EU-legislation.

According to this Common Principle the legal framework for understanding the exhaustion rules in general, and the concept of "consent" in particular, is found in IPR and not in national contract law. The Trade Marks-Directive has thus not only harmonized trade mark law but also areas of contract law with the aid of a "time bomb" labelled "consent". The formalistic and instrumentalist perception of exhaustion not only affects the choice of legal model - "Principle" (not "contract") - it also affects the application of the resulting rule, by making it clear that exhaustion should be perceived not only as a legal principle, but specifically as a trade mark (IPR) principle.

In a more concrete sense, the Common Principle identified here directs courts to establish "consent" based on the rules of EU-legislation (directive or regulation). In order to find out whether or not "consent" is present, therefore, one should not look to the "consent" expressed by the intention/will of the parties. "Consent" at the inter partes level is of course not unimportant, but the legal effects of the will of the parties is measured according to the rules in EUlegislation. If, for instance, the parties to an agreement want to limit parallel importation between EU countries and have made an agreement to that effect it would not violate trade mark law to breach that agreement if the conditions in Article 7 of the Trade Mark-Directive were met. ${ }^{36}$ This is the legislative/instrumentalist approach (“Zusammenhang der Benutzungsarten”) taken to its logical conclusion.

The Principle would seem to have horizontal effects and to also apply outside of trade mark law in all areas which have been harmonized and where exhaustion rules have been provided by directives or regulations such as in parts of copyright and design law. According to the Common Principle, courts which

35 ECJ, case C-324/08, Makro v. Diesel (not yet reported), para. 20-23.

36 Whether it would violate contract law and give rise to sanctions, termination, etc. will not be discussed here. 
have to interpret the word "consent" in Article 4(2) of the Infosoc.-Directive should, therefore, look to the rules of that Directive and on that basis decide whether concrete actions undertaken by parties to an agreement for the sale of copyright protected goods would amount to "consent". National rules or principles developed in contract law or in exhaustion models based on contract would be irrelevant as such.

\section{General Conclusion}

The policy principle behind the doctrine of exhaustion has been the creation of the EU Region. Because of this strong policy objective EU law has conceptualized "exhaustion" in the form of the Principle of Exhaustion. The discussions above have shown how the policy objectives have also affected the interpretation of the rules and made them more binding than one might expect. Not only do EU countries have to bring their legislation into harmony with the rules on exhaustion in the directives, but the Common Principle which has developed imposes obligations also on courts, etc. to use the rules in a specific way. This Principle has horizontal effects and applies to all harmonized (and probably also unharmonized) fields of IPR.

The Common Principle has developed over the time and on a step-by-step basis which has involved both elements of negative harmonisation (the Treaty) and rules of positive harmonization (directives). In these areas harmonization has been a dynamic process and the Common Principles have taken time to develop. The ECJ has played a very active role and has arguably constantly pushed for more and more harmonization. In this way, harmonization has been difficult to contain to specific areas of IPR or even to IPR proper but has, over time, spilled over into contract law. 



\title{
Common Principles of European Intellectual Property Law: a Polish Perspective
}

\author{
Igor B. Nestoruk
}

This article is written in reply to an invitation to take part in a conference about "Common Principles of European IP Law" (Bayreuth, 20 and 21 November 2009) organised by DFG Graduate School "Intellectual Property and the Public Domain" at the Bayreuth University. Its task is to present the current controversies in intellectual property law in Polish legal science. Further considerations are presented using a clear scheme based on the programme of the conference. This enables not only a determination of common points of interest for a pan-European discussion, but also a demonstration of elements specific to Poland. At the same time, it is worth stressing that the following overview uses only selected sources from the considerable and far more diverse Polish legal scholarship. Therefore, the selection made here is somewhat subjective, which can only be justified by the need to maintain coherence and to be up-to-date.

\section{Starting Points and Methodology}

The discussion on common principles of European IP law cannot be commenced otherwise than by determining the area of research and an adequate method or methods for the identification of these principles. Such an arrangement for the discussion seems systematically logical and convincing, however, in practice it turns out to be a very difficult challenge, though one that is worth taking up.

The proper area of research is determined by European law. This is a specific area not only because of its exceptional nature in the context of already known systems of law, but also because of its continuous and rapid evolution. As soon as the Lisbon Treaty took effect (1 December 2009) we commenced a new stage of developing European law. This means the need to review a great number of existing statements and assessments concerning both determinations of the scope (in internal and external terms) of European law standards and the 
need to adapt methods used to reconstruct their meaning to the current regulatory environment. This is expressly signalled by article 118 of the Treaty on the functioning of the European Union, an article that did not have an equivalent in the previous Treaties. Article 17.2 of the Charter of Fundamental Rights that is equally as authoritative as the Treaties is no less significant especially due to article 6.1 of the new Treaty of the European Union. Apart from primary law, secondary law is still the main "anchor area" of evolving standards determining European IP law.

Both primary law and secondary law affect domestic regulations differently though with similar force. Therefore, the term "European law" should be understood broadly and include, without limitations, those domestic provisions that are affected by the Europeanization process. In the field of IP law, EU law standards seem to impact upon the domestic framework commonly, though particularly given the fragmentary nature of EU regulations - there are still areas subject to the sovereign decisions of Member States' legislators. However, even with respect to such issues, Member States must take into account provisions of the Treaties, including those concerning market freedoms and the system of undistorted competition.

Distinguishing standards that have or might have the status of a "common principle" from this far from heterogeneous area is one thing; but another indispensable step is to determine the nature of such principles, their function and methods for resolving conflicts of principles, which are inherent in that specific category of standards, especially in private law ${ }^{1}$.

\section{Substantive IP Law}

When looking at more than 90 years of Polish experience of building a system of legal IP protection in the broad sense, it is worth emphasising that a regulation model has evolved in this field over time. The beginning of its first stage was determined by the day (10 November 1919) when Poland became a party to the Paris Convention. Then, the domestic model was based on three acts: the first on the protection of inventions, designs and trademarks in $1924^{2}$ and two further ones on copyright ${ }^{3}$ and unfair competition suppression ${ }^{4}$ enacted in 1926.

1 Safian, Pojęcie i funkcje zasad prawa prywatnego (The Notion and Functions of Principles of Private Law), in: Brzozowski/Kocot/Michałowska (ed.), W kierunku europeizacji prawa prywatnego. Księga pamiątkowa dedykowana Profesorowi Jerzemy Rajskiemu (Towards Europeanization of Private Law, Essays in Honour of Professor Jerzy Rajski (2007), p. 13.

2 Dziennik Ustaw [Official Journal] of 1925 no. 5, item 41.

3 Official Journal of 1926 no. 36, item. 260.

4 Official Journal of 1926 no. 96, item. 559, as amended. 
Another distinctive stage in Polish IP law development was the post-war period in the centralized economy. At that time, industrial property assets ${ }^{5}$ were not valued on a level comparable to that prevailing in states with a free market economy. Nonetheless, protection of such assets was regulated in several separate legal acts. Only changes in the late 1980s brought about an increase in the significance of intangible assets on the market. The Polish economy became more and more a part of the global market in exchange of goods and services. By consequence, the need to implement modern regulations was observed at that time. Poland's international obligations especially under the Europe Agreement $(1991)^{6}$ and the TRIPS Agreement (1995) were a significant stimulus for these reforms. These agreements resulted in the adoption of the Act on Protection of Topographies of Integrated Circuits (1992) ${ }^{7}$, the new Unfair Competition Suppression Act $(1993)^{8}$ and a year later the Copyright and Neighbouring Rights Act (1994) $)^{9}$.

In order to modernise Polish law an Industrial Property Law Act $(2000)^{10}$ was also drafted. This act not only integrates and reforms previous regulations governing the protection of inventions, utility models, industrial designs and trademarks. It also includes provisions on the protection of geographical indications as well as topographies of integrated circuits. The sui generis protection of databases provided for in Directive no. 96/9/EC was implemented in the Polish legal system from as early on as the pre-accession period. To this end, the Database Protection Act ${ }^{11}$ was adopted in 2001, which was amended considerably in 2007, especially as a result of criticism (raised in the literature) that it did not comply with the said Directive. To supplement this short overview of Polish regulations governing IP law, it is worth mentioning the Plant Variety Legal Protection Act ${ }^{12}$ of 2003. This act took effect on the day Poland became a member of the European Union and it replaced the existing regulations on the legal protection of plant varieties ${ }^{13}$.

${ }^{5}$ Promińska (ed.), Prawo własności przemysłowej (Industrial property law), $2^{\text {nd }}$ ed. (2005), p. 29.

6 Appendix to the Official Journal of 1994, no. 11, item 38, as amended. See in particular article 69 of the Agreement.

7 Official Journal of 1992, no. 100, item 498, as amended. Repealed under the Industrial Property Law Act (note 10 below).

${ }^{8}$ Consolidated text in the Official Journal of 2003, no. 153, item 1503, as amended.

9 Consolidated text in the Official Journal of 2006, no. 90 , item 631, as amended.

10 Consolidated text in the Official Journal of 2003, no. 119, item 1117, as amended.

11 Official Journal of 2001, no. 128, item 1402, as amended.

12 Official Journal of 2003, no. 137, item 1300, as amended.

13 Felchner, Nazwa odmiany rośliny chronionej wyłącznym prawem hodowcy (The denomination of the plant variety protected by the plant breeder's right), "Zeszyty Naukowe Uniwersytetu Jagiellońskiego. Prace z Prawa Własności Intelektualnej” "Papers on Invention and Protection of Intellectual Property") [hereinafter cited as "ZNUJ"] 105 (2009), p. 132 . 
Despite the strictly private law ambit of IP law, and especially the copyright regulation, the Polish legislature has not yet decided to cement it by adding it to the Civil Code. At first, it was argued that the relevant regulations were "immature" and that this was an obstacle to the implementation of the above solution. In the 1960s, whilst revisions were being undertaken on the currently applicable Civil Code, admittedly, it was proposed that copyright could be included in the Civil Code. Taking a pragmatic approach, at that time it was decided not to interfere with the existing regulatory regime, which was included in a separate act. At present it is argued that the relation between IP law and administrative and criminal law provides an argument in favour of preserving the status quo. The pace of the Europeanization of IP law and the resultant need to implement in domestic law amendments with increasing frequency are two factors which also in conflict with the assumption of stability made by the authors of the most recent vision of the draft Polish Civil Code ${ }^{14}$. At the same time, the issue of the implementation of IP law has been left open for further discussion without limiting assumptions having been formulated ${ }^{15}$.

Reflections on the system of IP protection and inquiries into its theoretical base often lead to different conclusions. In any case discussions in this field have not been confined to the domain of lawyers for quite some time now and economists or sociologists are equally active in such discussions ${ }^{16}$. Taking the patent protection system as an example, at present one specific result of the investigation of a specific shape for this system might be observed: patent data is informative ${ }^{17}$. However, might this statement also refer to other exclusive rights? After all, patent law itself makes us face questions in which economic arguments ${ }^{18}$ are mixed with social or philosophical ones ${ }^{19}$, which frequently reflect the complexity of national legal orders.

In any case, a remark made by a commentator on the first Polish Copyright Law Act when discussing limits of the author's monopoly might still be up-todate. According to his observation the regulation of that area of intangible as-

${ }^{14}$ Radwański (ed.), Zielona Księga. Optymalna wizja Kodeksu cywilnego w Rzeczypospolitej Polskiej (Green Paper. Optimal vision of the Polish Civil Code) (2006), p. 34.

${ }^{15}$ Ibid., p. 35.

16 About the "consumer syndrome" of the contemporary (postmodern) culture: Bauman, Płynne życie (Liquid Life) (2007), p. 96.

$17 d u$ Vall, Prawo patentowe (Patent law) (2008), p. 45.

18 Traple, Znaczenie wyłączenia spod pojęcia wynalazku programów komputerowych jako takich (The importance of exclusion of "as is" computer software from the notion of invention), "Przegląd Prawa Handlowego" ("Review of Commercial Law") [hereinafter cited as "PPH"] 3 (2008), p. 3.

19 Wtodarczyk, Zdolność patentowa zastosowań embrionów ludzkich - komentarz do decyzji Europejskiego Urzędu Patentowego w sprawie WARF/Thomson (Patentability of human embryo applications - commentary on the European Patent Office decision in the WARF/Thomson case), "Europejski Przegląd Sądowy” ("European Judicial Review”) [hereinafter cited as "EPS"] 10 (2009), p. 46. 
sets is strongly determined by the legislator's attitude. And this in turn results from "what limitations at a given stage of culture are required by its progress that absolutely depends on the very social nature of creative activity, the individual taking into account all the existing cultural works in a given field of creative activity, if possible" 20 .

Liability for torts committed on the Internet and concerning exclusive rights is an extremely complex issue ${ }^{21}$. At first glance, it might be said that civil law has had applicable tools for dealing with this issue for a long time - at least when it comes to regulating aiding and abetting (article 422 of the Polish Civil Code ${ }^{22}$ ). Such tools, however, appear to be inadequate for dealing with actions occurring in computer networks and by accompanying hosting services. Furthermore a doctrine formulating criteria for the delimitation of indirect and direct infringement upon such exclusive rights has not yet been developed in copyright law ${ }^{23}$. Thus, clear rules cannot be formulated without substantial difficulty. This has not been made easier by the implementation of Directive no. 2000/31/EC on electronic commerce ${ }^{24}$, which gives rise to interpretation disputes. Solutions proposed include de lege ferenda conclusions addressed not only to domestic ${ }^{25}$ but also to European legislators ${ }^{26}$. The appropriate use of traditional civil law constructions is discussed just as frequently given the various, and often unique, forms of action of parties infringing upon specific industrial property rights (e.g. trademarks) ${ }^{27}$.

Under the Polish Copyright and Neighbouring Rights Act, search for the right balance between the protection of the author's interests and the protec-

${ }^{20}$ Ritterman, Komentarz do ustawy o prawie autorskim (Commentary on the Copyright Act), 1937, p. 96.

${ }_{21}$ O konsekwencjach upowszechnienia internetu (About consequences of popularisation of the Internet): Mtynarska-Sobaczewska, Wolność wirtualnej wypowiedzi (Freedom of virtual expression), "Państwo i Prawo" ("State and Law") [hereinafter cited as "PiP"] 2 (2008), p. 48; Michalak, Przegląd cywilnoprawnych instrumentów ochrony portali internetowych (Internet portals: the overview of protection institutions under private law), "PPH" 4 (2010), p. 19.

22 Not only the person who directly caused the damage shall be liable but also any person who has induced or helped another person to cause the damage including those who consciously took benefit from a damage caused to another person.

${ }^{23}$ Barta/Markiewicz, Przechowywanie utworów na stronach internetowych (Storage of works on web portals), “ZNUJ” 105 (2009), p. 9.

${ }^{24} \mathrm{EU}$ regulations were implemented as early as in 2002 as an Electronic Supply of Services Act (Official Journal of 2002, no. 144, item 1204, as amended)

${ }^{25}$ Pacek/Wasilewski, Pomocnictwo w ujęciu cywilistycznym a odpowiedzialność dostawców usług hostingowych - dwugłos w sprawie (Contributory liability in the civil law approach and the liability of the hosting service providers - two opinions on the matter), "PPH" 7 (2008), p. 32.

${ }^{26}$ Barta/Markiewicz (supra, note 23), p. 29.

27 Tischner, Odpowiedzialność majątkowa za naruszenie prawa do znaku towarowego (Civil liability for trademark infringement), 2008, p. 128. 
tion of public interest is expressed in normative terms in the regulation of the contents of copyright law, and in particular, the permissible use of copyrighted works (articles 25-35). The analysis of this use is subject to particular controversies and a source of continuous disputes in the doctrine and practice of $\mathrm{law}^{28}$. The need to take the interests of consumers, i.e. users of works, into account has been increasingly observed ${ }^{29}$. Although the Polish regulation undoubtedly belongs to the civil law tradition, during the discussion on the limitations on the copyright monopoly, the attitude of the legal doctrine of Anglo-American models (such as the fair use doctrine) was considered to be noteworthy ${ }^{30}$. Initial voices of criticism have now been replaced by more favourable views stressing usefulness of this idea. This more friendly view is especially characteristic of the discussion on establishing the scope of the permissible use of works in computer networks. The doctrine is mostly sceptical when it comes to ideas of the "Americanization" of European law.

In the context of legislative changes concerning the provisions discussed here, the tendency towards European harmonization predominates. This was demonstrated, for instance, by amendments implemented to the Copyright Law Act in 2004 in order to adopt provisions of Directive no. 2001/29/EC. The literature used this opportunity to point out the inconsistency of the directive itself $^{31}$ as the adoption of an extensive list of optional limitations and exceptions ${ }^{32}$ may seem inconsistent with the need to counteract the existing legal uncertainty described in the preamble to the directive.

In the reality of an open market economy, the connection of a specified model of exhaustion of exclusive IP rights with the free circulation of goods is a key issue for the system of intangible asset protection. In Polish law, this matter has become the major topic of discussion among both practitioners and academics in the years preceding Poland's accession to the European Union. There were two main reasons for this interest. First, the Community-wide exhaustion strongly supported in European law required confrontation with regulations applicable in Poland. Meanwhile, under Polish law, there was no specific solution expressly formulated for acts concerning industrial property law. No solution at all had been developed

28 Chwalba, Korzystanie z programów peer-to-peer a dozwolony użytek prywatny w prawie autorskim (Peer-to-peer programs and permitted use in copyright law), “ZNUJ” 102 (2008), p. 19.

${ }_{29}$ Gienas, Imperatywny charakter dozwolonego użytku prywatnego? (Imperative character of permitted private use?), “ZNUJ” 106 (2009), p. 30.

30 See a review of literature in: Preussner-Zamorska, Dozwolony użytek chronionych utworów (Permissible use of protected works), in: Barta (ed.), System Prawa Prywatnego. Tom 13 - Prawo autorskie. (System of Private Law, Vol. 13 -Copyright), $2^{\text {nd }}$ ed. (2007), p. 426.

31 Preussner-Zamorska (supra, note 30), p. 460.

32 Which the Polish legislator benefited from and did not implement all forms of use of protected works as provided in the directive. 
in the practice of protecting inventions $\mathrm{s}^{33}$. Further, the extraterritorial exhaustion mode was supported in trade mark $\mathrm{law}^{34}$. This issue was only expressly regulated in Polish law when the Industrial Property Law Act was adopted. Given the status of integration with Community structures, it was decided to choose a formula combining domestic exhaustion with regional exhaustion (limited to those states with which Poland was bound by free trade agreements ${ }^{35}$. In view of Poland's deepening integration with the Community, this solution was only temporary. The need to achieve full harmonisation with acquis, hence to change the exhaustion model, required intertemporal rules to be duly formulated. This is because the regulations adopted in this area became a source of controversy. Opinions expressed in the literature helped to eliminate them ${ }^{36}$. Recently, the issue of exhaustion has returned, although now in a context of Europe-wide concern. It is discussed both in the context of using intangible assets on the Internet ${ }^{37}$ and in relation to the importance of parallel importation ${ }^{38}$.

\section{Enforcement and Fundamental Rights}

Just before the accession date, Directive no. 2004/48/EC on the enforcement of intellectual property rights was adopted. Hence, its implementation period coincided with the first years of Poland's membership in the EU. Legislative work on regulations implementing the directive into Polish law was accompanied by a vivid discussion. Then, the need for far-reaching amendments to Polish law, further than the directive had specified, seemed quite obvious. Given critical remarks made on the directive itself ${ }^{39}$, controversies concerning its implementation were, in a way, inevitable. One of the most important problems

$33 d u$ Vall (supra, note 17), p. 267.

${ }^{34}$ Skubisz, Prawo znaków towarowych. Komentarz (Trademark law. Commentary), $2^{\text {nd }}$ ed. (1997), p. 171.

35 Skubisz, Zakres wyczerpania praw własności przemysłowej w prawie polskim (The scope of exhaustion of industrial property rights in Polish law), "PPH” 1 (2002), p. 2.

${ }^{36}$ Promińska, Przepisy intertemporalne w zakresie znaków towarowych (Intertemporal provisions regarding trademarks), "PPH” 1 (2004), p. 1.

37 On the concept of exhaustion of intellectual property rights on the Internet: Zimmer-Czekaj, Prawa własności intelektualnej w wirtualnych światach (Intellectual property rights in virtual worlds), "ZNUJ" 105 (2009), p. 113; Radoniewicz, Ochrona programów komputerowych w prawie UE - cz. II (Protection of computer programs in the EU law - part II), “EPS” 5 (2009), p. 26.

38 Szczodrowski, Handel równoległy produktami farmaceutycznymi w orzecznictwie ETS (Parallel trade in pharmaceutical products in ECJ case law), "EPS” 10 (2009), p. 41.

39 Soltysinski/Nowicka, Uwagi o projekcie ustawy wdrażającej dyrektywę 2004/48/WE w sprawie egzekwowania praw własności intelektualnej (Remarks concerning the regulation implementing Directive 2004/48/EC on the enforcement of intellectual property rights), "Kwartalnik Prawa Prywatnego" ("The Private Law Quarterly”) 4 (2006), p. 1063. 
that occurred during the legislative process of implementing the directive was the difficulty in adjusting measures specified therein to principles of Polish civil procedure. Finally, the act implementing the directive took effect in June 2007 amending not only the regulations on copyright but also most domestic regulations mentioned above (excluding those governing unfair competition) ${ }^{40}$. The criticism of domestic solutions continues ${ }^{41}$. It refers to the doubts expressed in legal debate, whether the basic purpose of the directive, namely ensuring equal protection of IP rights in all Member States, can be achieved given difficulties resulting from the directive itself and its implementation. ${ }^{42}$. In the light of the problems mentioned here, transferring the burden of the transposition of Community law to the courts of Members States, which incidentally seems to be supported by ECJ case law ${ }^{43}$, can make it difficult to maintain a state of certainty in the law.

\section{Intellectual Property and Competition}

The division of competition law into antimonopoly law ${ }^{44}$ and unfair competition law has had a long tradition in Poland. Both subfields of competition law have much in common with intellectual property protection. However, both are subject to European harmonisation (pressures) to a different degree, which means that from the perspective of acquis, they should be analysed separately.

The Polish economy has become a part of the internal market. This is best demonstrated by antimonopoly law which has been harmonised with the common rules on competition in order to assist the pursuit of the goal of the internal market. On an institutional level, the Polish antimonopoly authority (President

40 See a report on the implementation of Directive 2004/48/EC in Poland, published by the Polish Ministry of Culture and National Heritage <http://www.mkidn.gov.pl/docs/pr_ autorskie-enforcement.pdf $>$.

41 Skubisz, Znaki towarowe - ewolucja przedmiotu ochrony prawnej (Trademarks - evolution of the object of legal protection), "PPH" 12 (2008), p. 22.

${ }^{42}$ Nowak-Gruca, Procesowe środki ochrony autorskich praw majątkowych na tle implementacji dyrektywy 2004/48/WE w sprawie egzekwowania praw własności intelektualnej (Procedural means of copyright protection against the background of implementation of Directive 2004/48/EC on the enforcement of intellectual property rights), "ZNUJ" 101 (2008), p. 72.

${ }^{43}$ As regards the ECJ judgment in case C-275/06 Promusicae: Wróbel, Sąd krajowy jako główne forum rozstrzygania kolizji praw podstawowych? (Is the national court the best place for adjudicating the conflict between fundamental rights?), "EPS" 3 (2008), p. 1; Prejs, Udostępnianie danych osobowych internautów dla celów postępowania cywilnego (Access to personal data of Internet users for the purposes of civil proceedings), "EPS" 4 (2009), p. 49.

${ }_{44}$ The basic regulation in this respect in Poland is the Consumers and Competition Protection Act of 2007 (Official Journal of 2007, no. 50, item 331, as amended). Król-Bogomilska, Kierunki najnowszych zmian polskiego prawa antymonopolowego (The directions of the most recent changes in the Polish antimonopoly law), "EPS" 6 (2009), p. 4. 
of the Office of Competition and Consumer Protection) is directly involved in the application of these rules ${ }^{45}$ within the European Competition Network. The European system of competition rules is increasingly affected by the pending processes of globalisation and the tightening of international business relations ${ }^{46}$. Its evolution will certainly impact upon national systems. The legal science therefore carefully monitors current tendencies in the development of European and American regulations, including their special and varied relationship to intellectual property $\mathrm{law}^{47}$.

Decisions of the Polish antimonopoly authority in cases concerning the prohibition on competition restricting practices applied to collective management organisations have been discussed very frequently recently in the context of domestic regulation. The tendency to treat such organisations (operating in Poland as societies of creators, performers, producers or radio and television organizations) as businesses the operations of which are governed by principles of competition law has given rise to some doubts in the literature ${ }^{48}$.

In turn, under unfair competition law, the relation between torts of unfair competition and the regulation of exclusive rights is still one of the most animatedly discussed issues ${ }^{49}$. Case law frequently supplies numerous examples of the parallel use of both regimes, first in the context of the convergence of the regulations on parasite imitation or the ban on confusing labelling and relevant standards of the Industrial Property Law Act ${ }^{50}$. Using a general clause as a ban on actions in conflict with good practices turns out to be extremely difficult

${ }^{45}$ Review of Polish case law: Miasik, Orzecznictwo w sprawach z zakresu wspólnotowego prawa konkurencji i ochrony konsumentów (Case law in the field of the Community law of competition and consumer protection), "EPS" 6 (2009), p. 62.

${ }^{46}$ Kolasinski, Perspektywy międzynarodowej harmonizacji prawa antymonopolowego (Prospects for the international harmonization of the law against monopolies), "PiP" 10 (2008), p. 46.

47 Borowicz, Porozumienia łaczenia i rozpowszechniania technologii w europejskim prawie konkurencji (Technology pools in the European competition law), "PiP" 5 (2010), p. 80; $d u$ Vall, Nadużycie pozycji dominujacej poprzez wykonywanie praw własności intelektualnej (Abuse of dominant position by exercise of intellectual property rights), "ZNUJ" 109 (2010), p. 5; Miasik, Wspólnotowe prawo konkurencji a prawa własności intelektualnej (Community competition law and intellectual property rights), "EPS" 6 (2009), p. 38; Nestoruk, Uwagi w sprawie tzw. doktryny "essential facility" oraz relacji miedzy prawem autorskim a prawem konkurencji (Remarks on so-called "essential facility doctrine" and the relationship between copyright and competition law), in: Lewandowski (ed.), Prawo autorskie a prawo konkurencji (Copyright and competition law), 2009, p. 147.

${ }^{48}$ See materials from a scientific conference: Lewandowski (ed.), Prawo autorskie a prawo konkurencji (Copyright and competition law), 2009.

49 Traple, Stosunek czynu nieuczciwej konkurencji do praw własności intelektualnej (The relationship between the act of unfair competition and IP rights), "ZNUJ" 77 (2001), p. 9.

${ }^{50}$ Nestoruk, Zivil- und strafrechtliche Aspekte des wettbewerbsrechtlichen Nachahmungsschutzes in Polen, in: Joerden/Scheffler/Sinn/Wolf (ed.), Vergleichende Strafrechtswissenschaft. Frankfurter Festschrift für Andrzej J. Szwarc zum 70. Geburtstag (2009), p. 745. 
when the risk of confusion is doubtful. In order to justify a breach of fair market rules, case law obviously uses the criterion of "hijacking" the reputation of the competitors ${ }^{51}$.

One of the most recent amendments to both acts forming the basis of Polish competition law is the one related to the implementation of directive no. 2005/29/EC on unfair commercial practices ${ }^{52}$. The Polish legislator, despite critical voices still being expressed at the beginning of the legislative process, here chose to implement the directive by way of a separate act on counteracting unfair market practices (2007). It changed, for example, the scope of the application of the Unfair Competition Suppression Act. It deleted a reference to consumers as a group of market players whose interests were expressly protected by the act since its enactment. The results of this amendment are still the source of controversy: not only about the working of competition law but also about the coherence of legal solutions. A major novelty of the Counteracting Unfair Market Practices Act is a provision that equips consumers with tools to bring individual actions against businesses (actio popularis) ${ }^{53}$. Further, under the Competition and Consumers Protection Act, practices infringing upon the collective interests of consumers also includes unfair market practices. Thus, it has become possible to counteract such practices also using administrative tools available to the President of the Office for Competition and Consumer Protection. In practice, this tool is used with increasing frequency in contrast to individual actions that seem to be very rare. In general, the method of the implementation of Directive no. 2005/29/EC in Polish competition law causes reasonable concerns about the further development of unfair competition suppression $\mathrm{law}^{54}$.

51 Jasinska, Relacja ochrony przyznanej na podstawie u.z.n.k. do wyłącznych praw własności intelektualnej na przykładzie problematyki naśladownictwa opakowań (The relationship between protection granted under the Act on Suppression of Unfair Competition and exclusive intellectual property rights on the example of problems of packaging imitation), “ZNUJ” 103 (2009), p. 86.

52 Stefanicki, Dyrektywa 2005/29/WE o nieuczciwych praktykach handlowych i jej implementacja do krajowego systemu (Directive 2005/29/EC concerning unfair commercial practices and its implementation in the domestic system), "PPH" 1 (2009), p. 10.

53 Sieradzka, Actio popularis jako instrument ochrony interesów konsumentów przed nieuczciwymi praktykami rynkowymi (Actio popularis as an instrument for protecting consumer interests against unfair market practices), "PPH” 3 (2008), p. 40.

54 Szwaja/Tischner, Dokąd zmierza prawo zwalczania nieuczciwej konkurencji? (Quo vadis unfair competition law), "ZNUJ” 100 (2007), p. 499. 


\section{Concluding Remarks}

The process of globalisation and, in particular, strong European harmonization leave a visible mark in Polish intellectual property law. Hence, past years have witnessed numerous amendments to the abovementioned regulations, mainly aimed at implementing EU regulations and the takeover of acquis in relation to intellectual property law.

It is a great honour to take part in a European discussion on the current problems of intellectual property law. Listening to the discussion one might get the impression that such an exchange of opinions is becoming normal practice within the European Union. Particular issues appear to involve the representatives of the various Member States equally. Academic research often performed independently demonstrates that the doubts and the questions raised are similar. Also in practice, in particular given the indications from ECJ case law, the similarity of problems (even despite differences in business reality), is no longer surprising nowadays. Therefore, efforts to encourage a European platform of exchange of thought among representatives of scientific and academic circles involved in the debate on the protection of intangible assets in Europe are understandable and deserve special support. 



\section{Enforcement \\ and Fundamental Rights}





\title{
The European Principles of Intellectual Property Enforcement: Harmonisation through Communication?
}

\author{
Marcus Norrgaird
}

\section{Introduction}

Over the last 15 years or so since the enactment of the TRIPS Agreement in 1994, stronger IP enforcement has been one of the megatrends in the field of intellectual property. Prior to this time there were some indications of the tendency to strengthen the enforcement system. The Court of Appeals for the Federal Circuit (CAFC), for example, which was founded in the early 1980s, favoured stronger IP protection by taking a particularly pro-patent stance. Also legislative measures in other countries, such as Sweden, in the 1980s gave some indication that there was a greater need for a stronger enforcement system.

The real paradigm shift, however, did not happen until the TRIPS Agreement, which introduced detailed provisions on many aspects of enforcement. Before TRIPS there had been only very few provisions in international treaties and the Community acquis. The European Union, on its part, introduced Directive 2004/48/EC on the enforcement of intellectual property rights ${ }^{1}$ ("IPRED"), which clearly forms part of this new paradigm. The purpose of IPRED is to set in place harmonised provisions on enforcement in the EU that ensure a high and homogenous level of protection. ${ }^{2}$ The individual provisions of the Directive are also more or less direct copies from TRIPS in many cases.

Other examples of the strengthening of the IP enforcement system are the bilateral TRIPS-plus Agreements that have been concluded in the last several years. An example of a provision that goes beyond the requirements of TRIPS (and even US national law) is the Chile-USA Free Trade Agreement, which includes a provision on the extension of patent protection if the grant process lasts longer than five years. Unlike TRIPS, which is silent on the issue of longer protection, the EU Directive on Supplementary Protection Certificates and the US

${ }^{1}$ Directive 2004/48/EC of the European Parliament and of the Council of 29 April 2004 on the enforcement of intellectual property rights, [2004] OJ L 159/16.

${ }^{2}$ IPRED, preamble, recital 10. 
Hatch-Waxman Act, Article 17(9) of the Chile-USA FTA is not limited to any specific field of technology (such as pharmaceuticals).

The latest example of the trend to strengthen protection is the Anti-Counterfeit Trade Agreement (ACTA), which has yet to be ratified. The purpose of the multilateral ACTA is to establish a common standard of enforcement to combat global IP infringement particularly in the context of counterfeiting and piracy by, for example, strengthening the enforcement measures. ${ }^{3}$

It has been argued that the strengthening of enforcement measures cannot go on ad infinitum. There are many examples of a countertrend. I will, however, limit myself to just a few examples. The Pirate Party, which has secured a mandate in the European Parliament, provides a clear indication of how this megatrend faces resistance. Already many years prior to the success of the Pirate Party lengthy discussions in the European Parliament during the legislative process concerning IPRED demonstrated that stronger enforcement is not a cure-all. The "follow-on" Directive to IPRED, the Draft directive on criminal measures (aka IPRED2) has met with severe resistance. Also, quite notably, big corporations have begun to notice the downside of overly strong enforcement: the so called non-practising entities (NPEs aka Patent Trolls) that acquire patents in order to extract royalties from big corporations and that rely on a strong enforcement systemt, are perceived as a real threat to many big corporations.

Both the megatrend and the corresponding countertrend are political in origin and connected to law through the principles of IP enforcement. Whilst the megatrend calls for stronger protection, the countertrend argues for weaker protection (or, to put it more positively, greater freedom). The desire for stronger or weaker protection needs to be "juridified" in order to be taken into account in the interpretation of legal provisions. This juridification takes place, for example, by the recognition of a number of accepted legal principles. In other words the conflict between the megatrend and its countertrend takes place when legal actors (e.g. courts, practising lawyers, academics) interpret the provisions of IP enforcement through, for example, invoking the principles of IP enforcement.

The purpose of this paper is to discuss what the principles of European IP enforcement are, where they can be found and what their role is in the legal system. This last point also includes a venture into how these principles should be balanced.

3 Discussion Paper on Possible Anti-Counterfeit Trade Agreement, http://cryptome.org/ acta/acta-proposal-2007.pdf, downloaded 1.2.2010. 


\section{Principles - what they are and why we have them}

The term 'principle' may be used in a multitude of senses. These include: principles as legal norms to be applied in making a legal decision (decision principles); principles as arguments made when interpreting legal sources such as statute law (interpretation principles); principles as reductions of the normative content of a certain body of law (such as intellectual property law or administrative law) or of the whole legal order (general principles of law); principles as legal sources that justify legal norms and principles as normative starting points for legislative solutions. ${ }^{4}$ The principles of IP enforcement are, as I see it, primarily interpretation principles according to this classification. The role of the principles is to aid in the interpretation of enforcement rules.

Although not universally accepted, the approaches of Ronald Dworkin ${ }^{5}$ and Robert Alexy ${ }^{6}$ have some merit in the context of the discussion of principles of IP enforcement. According to their view rules are applicable in an all-or-nothing fashion whereas principles apply more or less. In other words, a rule either applies or it does not, whereas a principle may be satisfied to varying degrees. A rule sets out the conditions of its application and the exceptions to the rule, whereas a principle states a reason that argues in one direction, but does not necessitate a certain outcome. Principles can therefore be said to be optimization requirements (Optimierungsgebote). ${ }^{7}$ Principles have a dimension of weight, which rules lack. This dimension of weight is used in resolving conflicts between two principles: a conflict between two principles is decided by determining which of the principles is the most important (i.e. has more weight) in the given case. A certain principle can prevail in a concrete case without making the opposite principle invalid. In another case balancing the principles may lead to the opposite decision. A conflict between two rules, however, means that either one of them must include an exception to accomodate the conflicting rule or be declared invalid and regarded as not being part of the legal system. Such questions of invalidity may, for example, be resolved by metarules such as lex posterior derogat legi priori (a later law repeals a prior one).

\footnotetext{
${ }^{4}$ Tuori, Oikeuden ratio ja voluntas (2007), p. 150.

${ }^{5}$ Dworkin, Taking Rights Seriously, (2009, first published 1977), pp. 22 et seq.

${ }^{6}$ Alexy E Rivers, A Theory of Constitutional Rights, (2002), pp. 44 et seq. Alexy's work was first published in German (Theorie der Grundrechte) in 1986.

7 Ibid., p. 47.
} 


\section{The IP enforcement principles}

\section{Principles of procedure and substance}

These core principles of European IP enforcement can be found in Article 3 of IPRED:

1. Member States shall provide for the measures, procedures and remedies necessary to ensure the enforcement of the intellectual property rights covered by this Directive. Those measures, procedures and remedies shall be fair and equitable and shall not be unnecessarily complicated or costly, or entail unreasonable time-limits or unwarranted delays.

2. Those measures, procedures and remedies shall also be effective, proportionate and dissuasive and shall be applied in such a manner as to avoid the creation of barriers to legitimate trade and to provide for safeguards against their abuse.

In a similar fashion Article 41(2) of TRIPS provides as follows:

1. Members shall ensure that enforcement procedures as specified in this Part are available under their law so as to permit effective action against any act of infringement of intellectual property rights covered by this Agreement, including expeditious remedies to prevent infringements and remedies which constitute a deterrent to further infringements. These procedures shall be applied in such a manner as to avoid the creation of barriers to legitimate trade and to provide for safeguards against their abuse.

2. Procedures concerning the enforcement of intellectual property rights shall be fair and equitable. They shall not be unnecessarily complicated or costly, or entail unreasonable time-limits or unwarranted delays.

These provisions contain the core principles of European IP enforcement. These principles can be divided into those that relate to the procedure or procedural law (I call these "procedural principles") and those that relate to substance or the sanction/remedy itself ("sanction principles").

\section{Procedural principles}

The procedural principles in IPRED and TRIPS are well-known and derive from the general procedural right to a fair trial. An analysis of the provisions above shows that Article 3(1) of IPRED deals with procedural principles (although the wording of the provision does not distinguish between procedure and substance): "[The] measures, procedures and remedies shall be fair and equitable and shall not be unnecessarily complicated or costly, or entail unreasonable time-limits or unwarranted delays.” Article 41(2) of TRIPS clearly pinpoints that this as a question of procedure: "Procedures concerning the enforcement of intellectual property rights shall be fair and equitable. They shall not be unnecessarily complicated or costly, or entail unreasonable time-limits or unwarranted delays.” 
In essence, Article 3(1) of IPRED and Article 41(2) of TRIPS provide for fast, cost-effective and fair proceedings. These are by no means novel requirements for civil, or for that matter, any legal proceedings. On a European level Article 6 of the European Convention on Human Rights (ECHR) in particular, provides for fair trials. In ECHR case law it has been settled that legal proceedings that take too long may violate Article 6 of the ECHR. ${ }^{8}$

The EU has also acknowledged the fair trial requirement. Article 6 of the Treaty on the Functioning of the European Union (TFEU) clearly acknowledges the role of fundamental rights in the European Union:

1. The Union recognises the rights, freedoms and principles set out in the Charter of Fundamental Rights of the European Union of 7 December 2000, as adopted at Strasbourg, on 12 December 2007, which shall have the same legal value as the Treaties.

$[\ldots]$

3. Fundamental rights, as guaranteed by the European Convention for the Protection of Human Rights and Fundamental Freedoms and as they result from the constitutional traditions common to the Member States, shall constitute general principles of the Union's law.

Article 47 of the Charter of Fundamental Rights of the European Union on the right to an effective remedy and to a fair trial provides as follows:

Everyone whose rights and freedoms guaranteed by the law of the Union are violated has the right to an effective remedy before a tribunal in compliance with the conditions laid down in this Article.

Everyone is entitled to a fair and public hearing within a reasonable time by an independent and impartial tribunal previously established by law. Everyone shall have the possibility of being advised, defended and represented.

Legal aid shall be made available to those who lack sufficient resources in so far as such aid is necessary to ensure effective access to justice.

Even before the TFEU, the ECJ had affirmed the role of the so called principle of effective judicial protection in, for example, UNIBET: "the principle of effective judicial protection is a general principle of Community law stemming from the constitutional traditions common to the Member States which has been enshrined in Art. 6 and Art. 13 of the European Convention on Human Rights and Fundamental Freedoms [...] and which has been reaffirmed by Art. 47 of the Charter of Fundamental Rights of the European Union."

I think that it is safe to assume that the fair trial provision of IPRED does not go beyond what is provided for in the ECHR and in the Charter. I believe that if the Council and the Parliament had wanted to set stricter fair trial requirements in IP cases clear rules should have been provided to this effect. A general fair

${ }^{8}$ For instance in the ECHR judgment in De Clerck v. Belgium, 34316/02, 25 September 2007, the court found that preliminary investigations in a criminal matter that had lasted 16 years and 3 months violated Art. 6. 
trial requirement is not enough to mandate, for example, faster proceedings in IP cases than in other types of private law cases. In principle it would have been possible to safeguard the time-effectiveness of IP proceedings through "fast track" provisions, but that would have required detailed rules (not principles) in order to secure its effectiveness.

\section{Sanction principles}

The sanction principles of IPRED and TRIPS are not novel either. These principles can be found in Article 3(2) IPRED and Article 40(1) of TRIPS. IPRED provides that the remedies shall be "effective, proportionate and dissuasive" and that they shall be applied in such a manner as to avoid the creation of barriers to legitimate trade and to provide for safeguards against their abuse. In a similar manner, TRIPS requires remedies that "permit effective action against any act of infringement of intellectual property rights covered by this Agreement, including expeditious remedies to prevent infringements and remedies which constitute a deterrent to further infringements". TRIPS also provides that the procedures shall be applied in such a manner as to avoid the creation of barriers to legitimate trade and that there needs to be safeguards against abuse.

The main or core principles are effectiveness, proportionality and dissuasiveness. These principles are well-known in general Community legislation due to the fact that quite a few directives and regulations end with a reference requiring national law to provide for "effective, proportionate and dissuasive" sanctions for breaches of the provisions of the directive/regulation at hand.

There are at least two different notions of effectiveness. The first notion of the principle of effectiveness is used in conjunction with the principle of equivalence. In ECJ case law it has been stated that effectiveness in this sense is a part of the principle of effective judicial protection, which means that "in the absence of Community rules governing the matter, it is for the domestic legal system of each Member State to designate the courts and tribunals having jurisdiction and to lay down the detailed procedural rules governing actions for safeguarding rights which individuals derive from the direct effects of Community law, provided that such rules are not less favourable than those governing similar domestic actions (the principle of equivalence) and that they do not render practically impossible or excessively difficult the exercise of rights conferred by Community law (the principle of effectiveness)."

The other notion in general Community law was laid down in case 68/88, Commission v. Greece: ${ }^{10}$

9 ECJ, case C-264/08, Belgische Staat v Direct Parcel Distribution Belgium NV, [2010] not yet reported, para. 33 .

10 ECJ, case 68/88, Commission v Greece, [1989] ECR 2965, paras. 23-24. 
It should be observed that where Community legislation does not specifically provide any penalty for an infringement or refers for that purpose to national laws, regulations and administrative provisions, Article 5 of the Treaty requires the Member States to take all measures necessary to guarantee the application and effectiveness of Community law.

For that purpose, whilst the choice of penalties remains within their discretion, they must ensure in particular that infringements of Community law are penalized under conditions, both procedural and substantive, which are analogous to those applicable to infringements of national law of a similar nature and importance and which, in any event, make the penalty effective, proportionate and dissuasive.

The principles of effectiveness means, simply put, that a sanction needs to be in place and is meant to be used in practice. ${ }^{11}$ The principle of dissuasiveness implies a certain level of severity in the sanction on top of this. ${ }^{12}$ It has also been suggested that dissuasiveness is a reference to what in criminal law is called general prevention and individual (or specific) prevention. Whilst general prevention is the "restraining influences emanating from the criminal law and the legal machinery", individual prevention may be characterised by the words "deterrence", "reformation" or "incapacitation". ${ }^{13}$ This notion of dissuasiveness, thus, has two sides: one which aims at stopping the infringer from continuing his infringement (individual prevention) and one that aims at stopping others from infringing (general prevention).

There is a link between effectiveness and disuasiveness, to the point that it may actually seem superfluous to have two principles which encompass different sides of the same concept. Instead, it would be preferable to have only one composite principle of effectiveness requiring as strong enforcement as possible. Below I will, unless otherwise indicated, use this composite notion of effectiveness.

The principle of proportionality, which balances effectiveness and dissuasiveness, requires that measures adopted by Community institutions do not exceed the limits of what is appropriate and necessary in order to attain the objectives legitimately pursued by the legislation in question. When there is a choice between several appropriate measures recourse must be had to the least onerous, and the disadvantages caused must not be disproportionate to the aims pursued. ${ }^{14}$

11 Pöysti, Tehokkuus, informaatio ja eurooppalainen oikeusalue (1999), p. 258.

12 Ibid., p. 259.

13 Andenaes, The General Preventive Effects of Punishment, 114 U Penn. L Rev. 949 (1966).

${ }_{14}$ See, for example, ECJ, case 331/88, FEDESA and others, [1990] ECR I-4023, para. 13; ECJ, joined cases C-133/93, C-300/93 and C-362/93, Crispoltoni and others v. Fattoria Autonoma Tabacchi and others, [1994] ECR I-4863, para. 41; and ECJ, case C-157/96, The Queen v. Ministry of Agriculture, Fisheries and Food and Commissioners of Customs E Excise, ex parte National Farmers' Union and others, [1998] ECR I-2211, para. 60. 
There is a slight difference between IPRED and TRIPS since TRIPS does not explicitly mention the proportionality of enforcement measures. It is, however, also possible to interpret TRIPS as requiring proportionality (anything else would seem unbalanced). Article 7 TRIPS on the objectives of the TRIPS Agreement requires a "balance of rights and obligations", which could be said to include an implicit principle of proportionality.

\section{The Role of the Principles}

\section{The open texture of rules allows room for discretion}

What is the role of these principles in European IP enforcement? When considering the sanction rules in IPRED and TRIPS, most of them seem to be rather vague, which makes it difficult to foresee the likely outcome in a given set of facts. Take, for example, the provision on interlocutory injunctions in Article 9 of IPRED that - simply put - provides that judicial authority may issue an interlocutory injunction when the applicant has provided any reasonably available evidence in order to satisfy the court with a sufficient degree of certainty that there is an infringement of the applicant's right. Furthermore, it is unclear in which cases an ex parte decision may be taken (i.e. in which cases an injunction may be issued without giving the defendant a right to be heard). Article 9(4) only requires that such a decision be possible "in appropriate cases [...] in particular where any delay would cause irreparable harm [...]". The application of such open-textured rules is difficult at best and impossible in most cases without the assistance of principles (and other arguments).

\section{National implementation of IPRED}

The role of these principles in the national implementation of IPRED has generally been limited. Just to name a few examples, in Finland the implementation followed a "minimum implementation" approach, i.e. as few amendments as possible were made to the Finnish provisions. This meant, for instance, that no separate explicit provisions on the principles were added to existing legislation. The government bill regarding the implementation (nr 26/2006) addresses the question of these principles only sporadically. For instance, as regards the right of information, Section 7a(1) of the Act on Securing Evidence in intellectual property cases (nr 344/2000) provides that the principle of proportionality may lead to the right of information not granted. According to the Government Bill, the court is to take into account the principle of proportionality when deciding whether to grant a right to publish the judgment at the infringer's ex- 
pense. ${ }^{15}$ Examples from other countries could be mentioned, but suffice it to say here that the approach of the Finnish legislature is by no means uncommon. The British implementation of IPRED, for example, also favoured a minimum implementation. Although there are examples of countries where implementation has been more progressive the rules, not the principles, of IPRED seem to have taken center stage in the implementation process although one could argue that the principles should be discussed in order to give meaning to the opentextured rules.

\section{The interpretation of sanction rules}

\section{a) How to give weight to principles}

Despite the limited role of the abovementioned principles in the implementation of IPRED, these principles are of great importance especially in the interpretation of the sanction rules on the right of information, final and interim injunctions, damages and the publication of court decisions. As I see it, the problem is not whether there are principles (which there are, as shown above) or whether they are of importance (which they are), but rather what meaning to give these principles. The principles are rather vague in themselves and arguments need to be found in order to give the principles their proper weight. The problem is how to find arguments that make a certain principle (for example effectiveness) more important than another (such as proportionality).

When assigning weight to the principles it is not possible to decide which principle ought to take ultimate precedence on an ex ante basis. It cannot be said that effectiveness should always weigh more than proportionality, as it could be said in the case of a principle such as the protection of human life when considered against the protection of property: it can be said that a human life is always more important than a piece of property. There is, however, no such absolute ex ante priority between effectiveness and proportionality in the field of IP enforcement. This means that the relative weight of the principles of effectiveness and proportionality can only be decided in the individual case after reviewing all the factual circumstances of that particular case. It is, however, possible to identify a number of typical scenarios in which the principles would normally be balanced in a certain way. This ex ante balancing might then change after the court has been presented with all the evidence.

I will try to pinpoint some factors to be taken into account in such a balancing act. These factors could be characterised more as methodological factors rather than substantive ones. By this I mean that they do not necessarily in themselves answer the question of how to assign weight between the principles

${ }^{15}$ Hallituksen esitys Eduskunnalle laeiksi teollis- ja tekijänoikeuksia koskevan lainsäädännön muuttamisesta 26/2006, p. 21. 
but rather indicate the process to be followed in assigning this weight and where to look for relevant arguments.

\section{b) Context sensitivity}

There are at least three such factors that are to be taken into account when assigning weight to the principles. The first factor is context sensitivity. In essence taking this factor into account acknowledges the fact that not all infringements are equal. Some infringements require more severe sanction than others. Although this is rather self-evident, legislative measures do not always pay enough attention to this fact. The TRIPS Agreement is not particularly clear on the division between different types of infringement. IPRED applies, at least at the outset, to all IP rights and to all infringements. For this reason it is all the more important that due regard is given to the context of the case when assigning weight to the principles.

The context of infringement can be described as a function of the infringer's person (company/private person), the infringer's intent to infringe (wilful, negligent, innocent infringer) and the type of IP right in question.

One possibility is to depict the outcome as a matrix that looks like the following (in the case of copyright infringement).

\begin{tabular}{llll}
\hline & Wilful infringement & Negligence & Innocent infringer \\
\hline Company & $\begin{array}{l}\text { Piracy/counterfeiting } \\
\text { or wilful B2B } \\
\text { infringement: } \\
\text { strongest enforcement }\end{array}$ & $\begin{array}{l}\text { Classical infringement: } \\
\text { "normal” enforcement }\end{array}$ & $\begin{array}{l}\text { Classical infringement: } \\
\text { normal enforcement } \\
\text { (injunction, only } \\
\text { limited damages?) }\end{array}$ \\
Private & $\begin{array}{l}\text { Piracy/counterfeiting: } \\
\text { ptrong enforcement? }\end{array}$ & $\begin{array}{l}\text { Blameworthiness? } \\
\text { Educational campaigns } \\
\text { instead of sanctions or } \\
\text { only limited sanctions? }\end{array}$ & No blameworthiness? \\
\hline & & & \\
\hline
\end{tabular}

Although the wording of the IPRED provisions might indicate that the same sanctions apply to all infringements equally, recital 17 of the preamble clearly requires the courts to exercise context sensitivity in interpreting the rules:

The measures, procedures and remedies provided for in this Directive should be determined in each case in such a manner as to take due account of the specific characteristics of that case, including the specific features of each intellectual property right and, where appropriate, the intentional or unintentional character of the infringement.

Context sensitivity is nothing controversial: it is something that courts engage in every day in each case before them. There was, however, a concern among some parties in the legislative process that IPRED might turn out to be too black and 
white and that courts would not see the differences between different cases. The original draft directive ${ }^{16}$ contained nothing on context sensitivity. Instead, it focused on the effectiveness of the measures (preamble, recital 16):

The measures and procedures designed to enforce intellectual property rights must be effective and place the right holder in the situation in which he would have been were it not for the infringement in question.

The addition of context sensitivity to IPRED ameliorated fears of too strict enforcement in cases where strict enforcement is not needed. Thus, the courts should be sensitive to the context of the case in their interpretative activities. In practice this means taking into account in the deliberations and in the judgment the factors discussed above: the infringer's person (company/private person), the infringer's intent to infringe (wilful, negligent, innocent infringer) and the type of IP right in question.

In the literature context sensitivity has been argued for in the interpretation of IPRED (although that term has not been used). ${ }^{17}$ In the case of final injunctions, for example, it has been noted that the problem is whether such injunctions should be issued as a matter of course once the infringement has been established. There are situations that may lead to disproportionate results and it has been submitted that disproportionality is a defence that may be invoked by the alleged infringer. At least five factors might be taken into account when weighing proportionality. ${ }^{18}$ According to what I call the consequentalist argument, an injunction would not be issued if the infringer's loss grossly outweighs the licence fee that reasonable parties would have agreed upon. The patent troll argument recognises that a patent owner that only has the aim of collecting licence fees (instead of producing and/or researching) could do so without an injunction. The proximity argument looks at whether the infringer has developed the infringing technology independently or whether it has been copied and how close the infringing product is to the patented invention: the closer the less reason there is not to enjoin. According to the big invention argument, broader protection would be given to bigger inventions due to the greater inventive step than to smaller inventions with a smaller degree of inventive step. Finally, the culpability argument acknowledges that the degree of responsibility could be taken into account: intentional infringements would be treated differently to negligent infringements.

16 Proposal for a Directive of the European Parliament and of the Council on measures and procedures to ensure the enforcement of intellectual property rights, COM (2003) 46 final.

17 Obly, Three principles of European IP enforcement law: Effectiveness, proportionality, dissuasiveness, in Drexl et al (eds.), Technology and Competition - Technologie et concurrence: Contributions in honour of Hanns Ullrich (2009), pp. 257-274.

18 Ibid., pp. 266-267. 


\section{c) Comparative law}

A further factor to be taken into account is comparative law. Basically this calls for a study of how principles have traditionally been balanced by courts in the member states of the European Union and why they have been balanced in this way. This in itself is nothing new. A well-known working principle of Community law is that comparative law is an accepted method of interpretation. ${ }^{19}$ The novelty is, however, in realising that comparative law should play a particularly important role in the interpretation of sanctions and procedural issues that have traditionally been very national and that still (despite IPRED and TRIPS) rest on a solid foundation of national law. The reason for this is in part that questions of procedure and sanctions can be very complex and entail many difficult judgment calls. It is difficult to foresee that an autonomous interpretation by the CJEU would - in the field of enforcement - be sufficiently rational without a good sense of the different national traditions. In part this is also about giving the Community legal order a "label of acceptability" in the field of enforcement. ${ }^{20}$ The Community legal order and the national legal orders are closely intertwined and the Community legal order can only function properly if the national legal orders consider CJEU decisions to be "compatible" with the traditions of the Member States and do not hurt special sensitivities in certain Member States. ${ }^{21}$ According to Lenaerts:

"The Community judge will thus try to establish ,the middle-line' which has the best chances of ,surviving' the relentless conflicts between the requirements of Community law and the interests of the national system. In other words, he will seek a solution that does not risk encountering incomprehension or resistance in some Member States, which could undermine the effectiveness and the uniform application of Community law. It can therefore be said that the comparative approach contributes in quite an essential way to guaranteeing the primacy, effectiveness and uniform application of Community law."22

For example, the two most important sanctions in IP law - damages and injunctions - today are still national to an extremely high degree. Therefore one should tread lightly when interpreting sanctions that have a long national tradition. Without taking national peculiarities and the reasons for them into account, the interpretations, most notably of the CJEU, would most likely lead to unwanted "Jack-in-the-box effects" 23 : an interpretatation novel to the national system would bring about strange side-effects. As long as the enforcement of

19 See for example Lenaerts, Interlocking Legal Orders in the European Union and Comparative Law", 52 ICLQ 873 (2003), p. 873.

20 Ibid., p. 879.

${ }^{21}$ Ibid., p. 879.

22 Ibid., pp. 879 et seq.

${ }^{23}$ Wilhelmsson, Jack-in-the-Box Theory of European Community Law, in Krämer/Micklitz/Tonner (eds.), Law and Diffuse Interests in the European Legal Order. Recht und diffuse Interessen in der Europäischen Rechtsordnung (1997), pp. 177-194, p. 180. 
intellectual property relies almost entirely on national courts, national traditions need to be taken into account. This is not, however, an argument against autonomous interpretations. On the contrary: a thorough look into national traditions makes for the best possible ground for rational and balanced autonomous interpretations.

As Lenaerts has shown, comparative law is of importance not only when there is a clear consensus about some concept or interpretation but also when there are profound contradictions between the views of courts in different member states: ${ }^{24}$

"Often, when the Community courts turn to comparative law in order to find inspiration for the interpretation of a concept of Community law they will find profound divergences in the interpretation given to the concept in question in the national legal systems. Such a finding may then provide a justification for establishing an autonomous interpretation of the concept in Community law.

They will, of course, see to it that this interpretation of Community law reconciles to the greatest extent possible the interests of the Community legal order with the requirent that the Community solution should be ,acceptable in the Member States."

\section{d) Fundamental Rights}

A further factor to take into account when weighing and balancing principles is fundamental rights. IPRED mentions fundamental rights explicitly in recital 2 of the preamble:

The protection of intellectual property should allow the inventor or creator to derive a legitimate profit from his/her invention or creation. It should also allow the widest possible dissemination of works, ideas and new know-how. At the same time, it should not hamper freedom of expression, the free movement of information, or the protection of personal data, including on the Internet.

In the light of this it is clear that at least the protection of property (including intellectul property ${ }^{25}$ ), freedom of expression and the protection of personal data are fundamental rights that need to be taken into account in the interpretation of the Directive. In addition to these other fundamental rights contained in the Charter of Fundamental Rights and the ECHR may be taken into account. Except for the right to a fair trial, which was already mentioned above, Article 8 of the ECHR and Article 7 of the Charter on the right to respect for private and family life, home and communications may be of importance, for example, in the interpretation of the invasive provisions in Articles 6 (order to present evidence), 7 (search order) and 8 (right of information). The right to respect for one's home may, for example, come into play when deciding whether

\footnotetext{
${ }^{24}$ Lenaerts, (supra, note 20), p. 896.

${ }^{25}$ Intellectual property is explicitly recognised in Art. 17 of the Charter of Fundamental Rights as part of the protection of property. Art 17(2) of the Charter provides that "intellectual property shall be protected".
} 
to grant a search order in a private person's home. The possibility of interference with the right to respect for one's home is acceptable according to Article 8(2) of the ECHR if the interference is in accordance with the law and necessary in a democratic society in the interests of national security, public safety or the economic well-being of the country, for the prevention of disorder or crime, for the protection of health or morals, or for the protection of the rights and freedoms of others. Thus, searches of one's home are acceptable only if they are in accordance with the law and necessary in a democratic society. Under the settled case law of the European Court of Human Rights the notion of necessity imples that the interference corresponds to a pressing social need and, in particular, is proportionate to the legitimate aim pursued. ${ }^{26}$ This means that the principle of proportionality is clearly quite important in interpretation, not only because of the provision in IPRED, but also, and especially, because it is required by fundamental rights analysis and the jurisprudence of the European Court of Human Rights. ${ }^{27}$ This does not, however, mean that proportionality necessarily trumps the principle of effectiveness that gains its weight from the protection of intellectual property in Article 17(2) of the Charter and the right to an effective remedy in Article 47(1) of the Charter. Fundamental rights need to be balanced in each individual case.

\section{Promusicae}

\section{The Case}

A case highlighting the importance of fundamental rights analysis in the interpretation of IPRED is the ECJ's decision in Promusicae ${ }^{28}$ in which the protection of intellectual property was weighed against the right to respect for private life.

On 29 January 2008, the ECJ handed down a preliminary ruling in this case concerning copyright holders' right to request the names and addresses of Internet users from an Internet service provider in a case of suspected infringement.

Promusicae, an association of Spanish music producers, had applied for an order against the Spanish Internet access provider Telefonica requiring it to disclose the names and addresses of certain Internet users. Promusicae claimed it had identified a number of IP addresses that had been used for illegal peer-to-

${ }^{26}$ See, for example, the decision of the ECHR, case Camenzind v. Switzerland, 21353/93, 16 December 1997.

27 The ECJ has also noted the protection of the home in competition law cases. See, e.g., ECJ, joined cases 46/87 and 227/88, Hoechst v. Commission, [1989] ECR 2859, para. 17 where the court recognises that the fundamental right to the inviolability of the home "must be recognized in the Community legal order as a principle common to the laws of the Member States."

${ }^{28}$ ECJ, case C-275/06, Promusicae, [2008] ECR I-271. 
peer (P2P) file sharing of music files using the software system Kazaa. Only the Internet access provider, however, could know the identity of the persons behind the IP addresses.

According to Spanish law, an Internet access provider is obliged to provide this information only in cases of criminal investigations, to protect public safety, or if national security is involved. The Spanish market court was of the opinion that a contradiction existed between Spanish and Community law. Therefore, it asked the ECJ whether Community law requires member states to lay down an obligation to communicate personal data in the context of civil proceedings, in order to ensure the effective protection of copyright.

In its answer the ECJ had to consider many different provisions from several legislative Acts: on the one hand provisions on the enforcement of IP rights (TRIPS, InfoSoc Directive 200/29/EC, Directive on electronic commerce 2000/31/EC, Enforcement Directive 2004/48/EC and the Charter on Fundamental Rights), and on the other hand provisions on the protection of personal data (Directive on the protection of personal data 95/46/EC and Directive on privacy and electronic communications 2002/58/EC).

On the face of it, Article 8 of the Enforcement Directive seems to favour the copyright holder. It provides that courts shall have the right to order that information on the origin and distribution networks must be revealed by, inter alia, the person providing the services used on a commercial scale in the infringing activities. However, according to Article 8(3)(e) this applies without prejudice to, inter alia, provisions on the processing of personal data.

Even so, the ECJ, contrary to Advocate General Kokott's opinion, found that the provisions on the protection of personal data do not preclude the communication of the names and addresses of Internet users in the context of civil proceedings. The ECJ based its argumentation on Article 13(1) of the Directive on the protection of personal data $(95 / 46 / \mathrm{EC})$. This Article provides that the member states may restrict the obligation of confidentiality of personal data where that restriction is necessary, inter alia, for the protection of the rights and freedoms of others - including, according to the ECJ, intellectual property rights.

The ECJ then went on to consider whether there is an outright obligation to require Internet service providers to disclose personal data. Although the ECJ scrutinised the IP directives in detail, it did not find any such obligation. Instead, it concluded that it is up to the member states to strike a fair balance between fundamental rights and other general principles of Community law. Thus, the ECJ left it to the national court to interpret the directives in the light of the fundamental right of respect for private life (i.e. the protection of personal data) on the one hand and the rights to the protection of property (including intellectual property) and to an effective remedy on the other. 


\section{Comment}

To some this decision might seem to show the ECJ surrendering in the face of difficult questions. Why did the ECJ confine itself to providing the tools (i.e. the argumentation model) and not address the issue itself? It is of course difficult to say for sure, but some plausible reasons can be outlined. First of all, enforcement has become a very political question with variations in the views of the individual member states. This is especially clear in light of the manner in which the right to information has been implemented in the member states. It is possible that the ECJ did not really want to enter this minefield. It is also possible that the traditionally strong procedural autonomy of the member states was taken into account: procedural law is a delicate and very traditional field of law that has been influenced by European law only to a limited degree. National rules of procedure and remedies are also known for their resilience to change due to the strength of national traditions. Furthermore, it could be speculated that since fundamental rights were at issue, the ECJ felt that the questions were too delicate to be decided by the ECJ.

In connection with this argument the question of subsidiarity may have been taken into account: perhaps the national court is better suited to decide this issue. Such a view of subsidiarity would not only affect the interpretation of the provision on the right to information, but could also indicate the ECJ's willingness to let national courts decide difficult questions relating to other remedies (such as the requirements for damages). It could also be argued that one size does not fit all and that the ECJ feels that there should be differences in how the individual member states deal with issues of IP enforcement (although IPRED has an opposite purpose).

In any case it is clear that the provisions on IP enforcement have rapidly evolved from virtually no provisions at all (before the TRIPs Agreement) into a field with complex and far-reaching provisions. It is only natural that the ECJ is cautious in entering this field.

The ECJ has not always been reluctant to give clear guidance in the field of IP enforcement. In Nokia v. Wärdell ${ }^{29}$ the ECJ gave a clearcut answer on some requirements for final injunctions. The question was whether a final injunction should be issued in a community trademark infringement case. According to Article 98 of the CTMR a final injunction shall be issued if the defendant has infringed or threatened to infringe a Community trade mark, unless there are special reasons for not doing so. The case was essentially about what those special reasons are. The Swedish court submitted four questions to the ECJ, asking for a preliminary ruling. The first question was in essence whether there is a special reason required by Article 98 of the CTMR if the risk of further infringement is

29 ECJ, case C-316/05, Nokia v. Wärdell, [2006] ECR I-12083. 
not obvious or is otherwise merely limited. The ECJ answered in the negative: there is no special reason not to enjoin the defendant even though the risk of further infringement is limited. The second question was basically whether there is a special reason if there is a statutory general prohibition on infringement under national law and a provision that a penalty may be imposed on the defendant if he commits a further infringement intentionally or with gross negligence. With this question the Swedish court wanted to know whether a criminal provision is to be regarded as a special reason. The ECJ did not see that a criminal provision could be a special reason. The third question was about whether the national court is under an obligation to fine the defendant in the case of a breach of the injunction in cases where there is a criminal law provision. The ECJ stated that the national court is required to take such measures as are aimed at ensuring that that prohibition is complied with meaning that a fine might have to be ordered if the defendant otherwise refuses to comply with the injunction, although there is also a criminal law provision in place. The fourth question was about whether an obligation to issue an injunction applies even though there is no similar obligation for national trademarks; to which the ECJ answered that there is such an obligation.

In the light of these clearcut answers, it could be argued that the Court of Justice is willing to tread into the realm of civil procedure and sanctions and that my speculations above about the ECJ's unwillingness cannot be true. It should, however, be noted that the issues in Nokia v. Wärdell were only controversial in Sweden. The situation in Sweden was rather anomalous compared to the rest of Europe. For a long time the governing idea in Sweden was that it is not possible to issue an injunction in cases that might - at least in theory - lead to criminal sanctions. The idea was that a breach of an injunction may lead to the payment of a fine (which is paid to the state but which strictly speaking is not a criminal law fine). Since a breach of criminal law provisions may also lead to fines there is, supposedly, a risk of sanction cumulation (i.e. the infringer may end up paying double fines). As far as I know this doctrine has not been of relevance in any other European country. In Finland the doctrine has been discussed but disregarded since it is possible in sentencing to take into account other sanctions the defendant has been subjected to (by lowering the fine to be paid). This kind of mechanism means that there is no real risk of sanction cumulation.

The questions posed to the ECJ were, I would argue, easy to answer on the basis of a comparative law study: an injunction should be issued even if the infringement is not obvious and even though there are criminal law provisions and even though the same possibility is not open to national trademarks. Nokia represents an easy case whereas Promusicae was a hard one. The ECJ acted correspondingly: it decided the Nokia case clearly and unambigously, whereas it only provided the tools (argumentative model) for the decision in Promusicae. Thus, I maintain that the Court of Justice might be a bit reluctant in treading the waters of national procudure and sanctions, at least in hard cases. 
The question now is what follows if my view is correct that the Court of Justice is reluctant to decide difficult enforcement questions? The fact that the ECJ only gave the national courts the tools and not the final answer means that the national courts are vested with a substantial amount of discretion. Elsewhere, I have argued that the directive gives room for both a weak and a strong enforcement ideology meaning that it can be interpreted both as favouring the rightsholders and the alleged infringers. ${ }^{30}$ With its decision the ECJ (perhaps inadvertently) reinforces this situation. The decision does not clearly favour either strong or weak enforcement, but leaves it for the national judge to decide. Whether national judges adopt a strong or a weak enforcement strategy will depend heavily on how the national court balances the principles of effectiveness, proportionality and dissuasiveness. I would argue that the national traditions of the deciding court will dictate the interpretations of IPRED for the foreseeable future. Member states will likely continue on the road they have followed previously (strong or weak enforcement), unless national judges really take notice of the balancing act now prescribed by the ECJ. It is clear that such a path might lead to disharmonisation instead of harmonisation as the Directive requires. The question is really how to harmonise the balancing of principles.

\section{Conclusion - Harmonisation through Communication}

If we want true harmonisation of the rules on procedure and sanctions we need to go a step further than harmonisation through legislation which has not been that fruitful: IPRED is too vague to bring about true harmonisation in most instances. Harmonisation through ECJ/CJEU case law will probably only solve the easy questions while leaving the hard cases to the national courts to decide. Therefore, I suggest that we try harmonisation through communication. The reasons for the disparate application of the rules in the member states might be found in the different balancing of the underlying principles. This would be done through increased communication between national courts in different member states and thus increased understanding of divergent interpretations. This approach would be similar to that of the English and German courts in the interpretation of Article 69 of the EPC. On top of this legal scholarship would play a role through a comparative academic endeavor looking into why different countries emphasise the principles differently. This too would increase understanding of the reasons for such a different emphasis, which in the long run could increase harmonisation or at least willingness to harmonise.

30 Cf. Norrgaird, The Role Conferred on the National Judge by Directive 2004/48/EC on the Enforcement of Intellectual Property Rights, ERA-Forum 4/2005, pp. 503-514. 
A counterargument to this approach is that (at least) community rights need to rely on autonomous interpretations. I maintain, however, that there is no conflict between autonomous interpretations and harmonisation through communication, which in essence relies on applying the comparative legal method, which is a recognised principle of interpretation in the ECJ. Applying the comparative methodology is necessary in the hard cases since national traditions play the most important role in these uncertain cases. I would argue that as long as we do not have separate community IP courts we cannot disregard national traditions, which in the field of procedure and sanctions, are quite strong.

To conclude: harmonisation and acceptable autonomous interpretations can only be achieved by gaining a thorough understanding of the different national traditions. It is for the courts and academics to start discussing these traditions and thus achieve harmonisation through communication. 



\title{
Fundamental Rights as Common Principles of European (and International) Intellectual Property Law*
}

\author{
Christophe Geiger
}

Fundamental rights have always played an important role in the European legal order and their role is always increasing. A new and important step has recently been made in this regard by the Treaty of Lisbon which amended the Treaty on European Union and the Treaty establishing the European Community. It was signed at Lisbon on 13 December 2007 and entered into force on 1 December 2009, after the text was ratified by all Member States ${ }^{1}$. In fact, this treaty gives the Charter of Fundamental Rights a legally binding force and integrates this text into the primary legislation of the European Union $(\mathrm{EU})^{2}$. This has been

* This article draws on previous publications by the author on the relationship of fundamental rights and IP in the European Union, in particular: 'Constitutionalising' Intellectual Property Law?, The Influence of Fundamental Rights on Intellectual Property in Europe, 37 IIC 371 (2006) and Copyright's Fundamental Rights Dimension at EU Level, in: Derclaye (ed.), Research Handbook on the Future of EU Copyright (2009), p. 27.

1 OJEU 17 December 2007, 2007/C 306/01. A consolidated version of the Treaty on European Union and the Treaty on the Functioning of the European Union, as they will result from the amendments introduced by the Treaty of Lisbon, has been published in the Official Journal of the European Union (OJEU 30 March 2010, 2010/C 83/01). For commentary on the Treaty of Lisbon see e.g. Craig, The Treaty of Lisbon, Process, Architecture and Substance, [2008] ELR 2008, 137; Lenaerts, De Rome à Lisbonne, la Constitution européenne en marche?, 3-4 Cahiers de Droit Européen 229 (2008) ; Weber, Vom Verfassungsvertrag zum Vertrag von Lissabon, EuZW 2008, 7. On the consequences of the Treaty of Lisbon for intellectual property in particular, see Geiger, Intellectual "Property" after the Treaty of Lisbon, Towards a different approach in the new European legal order?, [2010] EIPR 255.

${ }^{2}$ Nevertheless, it must be pointed out that there are important restrictions for Poland, the United Kingdom and the Czech Republic. See Art. 1 of the Protocol on the Application of the Charter of Fundamental Rights of the European Union to Poland and to the United Kingdom (OJEU 17 December 2007, C 306/157, that became Protocol 30 in the consolidated versions of the Treaties, OJEU 30 March 2010, C 83/313), stating that " 1 . The Charter does not extend the ability of the Court of Justice of the European Union, or any court or tribunal of Poland or of the United Kingdom, to find that the laws, regulations or administrative provisions, practices or action of Poland or of the United Kingdom are inconsistent with the fundamental rights, freedoms and principles that it reaffirms; 2. In particular, and for the avoidance of doubt, nothing of Title IV of the Charter creates justiciable rights applicable to Poland or the United Kingdom except in so far as Poland or the United Kingdom has provided for such 
clearly stated in the amended version of Art. 6 (1), which holds that "the Union recognises the rights, freedoms and principles set out in the Charter of Fundamental Rights of the European Union of 7 December 2000, as adapted in Strasbourg, on 12 December 2007, which shall have the same legal value as the Treaties". Furthermore, according to the new version of Art. 6(2), the Union will accede to the European Convention for the Protection of Human Rights and Fundamental Freedoms, an accession that so far has been impossible due to a problem of competence of the Community ${ }^{3}$. This will without a doubt increase the application of fundamental rights reasoning by the Court of Justice of the European Union (CJEU). This is made clear by the declaration on the new Art. 6(2) of the Treaty on European Union, where it is stated that "the Conference agrees that the Union's accession to the European Convention for the Protection of Human Rights and Fundamental Freedoms should be arranged in such a way to preserve the specific features of Union law. In this connection, the Conference notes the existence of a regular dialogue between the Court of Justice of the European Union and the European Court of Human Rights; such dialogue could be reinforced when the Union accedes to the Convention"4.

In any case, even before the Treaty of Lisbon entered into force, in a decision on 27 June 2006, the European Court of Justice (ECJ, now CJEU) directly referred to the Charter of Fundamental Rights when testing the validity of a directive $^{5}$. In fact, according to the Court, even if the Charter was not a legally binding instrument, it reaffirms the general principles of community law arising from the European Convention for the Protection of Human Rights and constitutional provisions common to the Member States, principles that are, without any doubt, binding on the European institutions $s^{6}$. Furthermore, refer-

rights in their national law". At the Council of the European Union on 29 October 2009, the Czech Republic obtained the political promise from the other EU member states that it would have the same restrictions applied to it and that Protocol 30 would be modified in order to add the Czech Republic when a treaty of accession of a new member to the EU is signed.

${ }_{3}$ See clearly in this sense the opinion 2/94 of the ECJ, 28 March 1996, "Accession by the Community to the European Convention for the Protection of Human Rights and Fundamental Freedoms", [1996] ECR I-1759. On this issue, see Blumann, Les compétences de l'Union en matière de droits de l'homme, 1 Revue des Affaires Européennes (RAE) 11 (2006).

${ }^{4}$ Declaration on Art.6(2) of the Treaty on European Union, OJEU 30 March 2010, C $83 / 337$.

${ }^{5}$ ECJ, case C-540/03, Parliament v. Council, [2006] ECR I-05769, para. 38; for a comment see Bailleux, La Cour de Justice et les droits de l'homme: à propos de l'arrêt Parlement c. Conseil du 27 juin 2006, 2006 JT 589; Burgogue-Larsen, L'apparition de la Charte des droits fondamentaux de l'Union dans la jurisprudence de la CJCE ou les vertus du contrôle de légalité communautaire, AJDA 4 December 2006, 2285.

6 See also since then ECJ, case C-432/05, Unibet, [2007] ECR I-2271, para. 37 (for a comment see Van Waeyenberge/Pecho, L'arrêt Unibet et le Traité de Lisbonne- Un pari sur l'avenir de la protection juridictionnelle effective, 1-2 Cahiers de droit européen 123 (2008)); ECJ, c-303/05, Advocaten voor de Wereld, [2007] ECR I-3633, paras. 45 and 46. According to Iliopoulou, Assurer le respect et la promotion des droits fondamentaux: un nouveau défi pour 
ences have increasingly been made to fundamental-rights values in the recitals of the latest directives on intellectual property ${ }^{7}$ and provisions of the Charter have been cited in derivative legislation many times since its adoption ${ }^{8}$. In the case-law of European Court of Human Rights, intellectual property has also entered the field of fundamental rights as the Court has issued more and more rulings interpreting IP-relevant provisions of the European Convention on Human rights, and especially the right to property 9 .

But the importance of fundamental rights in the legal systems of many European countries has mostly increased over the last few years due to the direct applicability of the provisions of the European Convention on Human Rights in private law disputes. Indeed, in theory and practice it has been progressively admitted that the provisions of the Convention have not only a vertical effect, but also a horizontal effect, and therefore also apply to relationships between individuals ${ }^{10}$. With this increase in the application of the provisions of the Eu-

l'Union Européenne, 3-4 Cahiers de droit européen 441 (2007), the Charter had therefore already gained a binding character even before the entering into force of the Lisbon Treaty.

7 See Recital 3 of the Directive of the European Parliament and of the Council on the harmonisation of certain aspects of copyright and related rights in the information society of 22 May 2001 (OJEC L 167, 22 June 2001, at 10); Recitals 2 and 32 of the Directive of the European Parliament and of the Council on the enforcement of intellectual property rights from 29 April 2004 (OJEC L 157, 30 April 2004, at 45); Recital 16 of the Directive 98/44/EC of the European Parliament and of the Council of 6 July 1998 on the legal protection of biotechnological inventions (OJEC L 123, 30 July 1998, at 13); Recital 12 of the Amended proposal for a Directive of the European Parliament and of the Council on criminal measures aimed at ensuring the enforcement of intellectual property rights of 26 April 2006, COM (2006) 168 final.

8 See the numerous references cited by Iliopoulou in her article cited supra, note 6, at 435, note 48 . As this author points out, the reference to the Charter by the Commission was made on purpose to give these provisions more weight from a legal point of view. See clearly in this sense the Communication from the Commission, "Compliance with the Charter of Fundamental Rights in Commission legislative proposals”, 27 April 2005, COM (2005) 172 final. According to Iliopoulou, this strategy was chosen by the European institutions to take the process of "constitutionalisation" of the European construction one step further.

${ }^{9}$ See e.g. in the field of trade marks: ECHR, Anbeuser Busch Inc. v. Portugal (Appl. No. 73049/01), confirmed by the Grand Chamber of the ECHR, (2007) 4 Journal of Intellectual Property Law \& Practice 197, comment by Goebel. On this case, see also Beiter, The Right to Property and the Protection of Interests in Intellectual Property- A Human Rights Perspective on the European Court of Human Rights' Decision in Anheuser-Busch v. Portugal, 39 IIC 714 (2008). In the field of patent law, see the decision of the former European Commission of Human Rights Smith Kline and French Laboratories Ltd. $v$. The Netherlands (Appl. No. 12633/87), 66 D.R. 70 (1990). In the field of domain names, see ECHR, Sect. 5, Paeffgen GMBH v. Germany, No.25379/04, No.21722/05 and No.21770/05. In the field of copyright, see ECHR, $4^{\text {th }}$ section, Balan v. Moldova, Appl. No. 19247/03, No. 34. For a detailed analysis of the intellectual property case law of the European Court of Human Rights, see Helfer, The New Innovation Frontier? Intellectual Property and the European Court of Human Rights, 49 Harvard International Law Journal 1 (2008), reprinted in a modified version in: Torremans (ed.), Intellectual Property and Human Rights (2008), p. 25.

10 See Clapham, The 'Drittwirkung' of the Convention, in Macdonald/Matscher/Petzold (eds.), The European System for the Protection of Human Rights (1993), p. 201.; Alkema, 
ropean Convention to private law litigation, civil judges have been dealing with fundamental rights and have had to learn to handle them, and specifically to understand their own logic such as the proportionality test that applies to resolve conflicts between two opposing fundamental rights, a procedure that is alien to the tradition of many European countries, especially those of which have a civil law tradition. Thus, civil law judges in various European countries have applied the fundamental rights in the European Convention in the domain of intellectual property in a number of decisions ${ }^{11}$.

This evolution should be welcomed. Indeed, the fact that countries place increasing emphasis on their economic well-being has led to a new transfer of power from the state to industry. This must have consequences for positive law: as misuse of power might now also come from economic actors, and from now on individual freedoms must not only be protected vis-à-vis the state, but also vis-à-vis private persons ${ }^{12}$. In addition, this shift of power from the state to private entities has gone hand in hand with a growing tendency for intellectual property rights to be shaped according to the claims of strong lobby groups and to extend outside their traditional boundaries ${ }^{13}$. This development made it increasingly necessary for judges to intervene, invoking external rules - such as fundamental rights - in order to correct the overprotective tendencies of intellectual property legislation and to reestablish a proper balance of interests. Therefore, as it has been fittingly stated by one scholar, fundamental rights law

The Third-Party Applicability or "Drittwirkung” of the European Convention on Human Rights, in: Matscher/Petzold (eds.), Protecting Human Rights: The European Dimension, Studies in Honour of G.J. Wiarda (1988), p. 33; Coussirat-Coustère, Convention européenne des droits de l'homme et droit interne: primauté et effet direct, in: Pettiti/Decaux/Imbert (eds.), La Convention européenne des droits de l'homme, $2^{\text {nd }}$ ed. (1999), p. 14.

11 On these cases see Geiger, "Constitutionalising” Intellectual Property Law?, The Influence of Fundamental Rights on Intellectual Property in Europe, 37 IIC 371 (2006).

${ }^{12}$ See in this sense, in the field of freedom of expression, Birnhack, Acknowledging the Conflict between Copyright Law and the Freedom of Expression under the Human Rights Act, [2003] Ent. LR 30: “As western democracies turn more and more to market-oriented economies and cultures the source of the threat to the freedom of speech spills over to other players in the democratic field as well, namely the market"; Macmillian Patfield, Towards a Reconciliation of Free Speech and Copyright, in: Barend (ed.), The Yearbook of Media and Entertainment Law 1996 (1996), p. 208, stating that "distinguishing between state power and private power in the ability to constrain speech is problematic, as private figures can constrain speech remarkably effectively".

${ }^{13}$ See on this issue for example Hilty, The Expansion of Copyright Law and its Social Justification, in: Heath/Liu (eds.), Copyright Law and the Information Society in Asia (2007), p. 1; Cornish, The Expansion of Intellectual Property Rights, in: Schricker/Dreier/Kur (eds.), Geistiges Eigentum im Dienste der Innovation (2001), p. 9; Dreyfuss/Zimmermann/First (eds.), Expanding the Boundaries of intellectual property (2001); Gyertyanfy, Expansion des Urheberrechts - Und kein Ende?, GRUR Int. 2002, 557; Laddie, Copyright: Over-strength, Over-regulated, Over-rated?, [1996] EIPR 253; Netanel, Why has Copyright Expanded? Analysis and Critique, in: Macmillan (ed.), New Directions in Copyright Law, Vol. 6 (2007), p.3. 
has become "intellectual property's new frontier" in Europe ${ }^{14}$. Before analyzing its consequences for intellectual property, we will present the content of the fundamental rights framework in the European Union.

\section{The European Framework relating to Fundamental Rights}

The framework of Fundamental Rights protection within the European Union consists of the provisions of the ECHR, the European Charter for Fundamental Rights and the provisions of the different national constitutions. The standard of fundamental rights protection within the EU, however, is much broader. The ECJ has declared that when construing the Community standard of fundamental rights protection, it draws inspiration "from guidelines supplied by international treaties for the protection of human rights on which the Member States have collaborated or of which they are signatories"15. This means that the Universal Declaration of Human Rights (UDHR) and the International Covenant on Economic, Social and Cultural Rights (ICESCR) are also part of the European framework for fundamental rights and should be taken into account.

This is a significant factor as these international treaties have modern and balanced provisions on intellectual property protection. In fact, immaterial assets are explicitly named in Art. 27 of the UDHR of $1948:{ }^{16}$ According to Art. 27(1) everyone has "the right freely to participate in the cultural life of the community, to enjoy the arts and to share in scientific advancement and its benefits", while according to Art. 27(2) everyone has the right to the protection of moral and material interests resulting from any scientific, literary or artistic production of which he is the author. Art. 15(1) of the ICESCR of 19 December $1966^{17}$ adopted the wording of the UDHR almost verbatim. It is important to emphasise that neither the UDHR nor the ICESCR determine that the material and immaterial interests of the creators should be protected by way of a property right. That means that within the scope of these conventions, other means of protection might certainly be chosen by legislators. Thus, these two texts leave countries a good deal of room to manoeuvre, while at the same time guar-

${ }^{14}$ Helfer, (supra, note 9).

15 See e.g. joined cases C-20/00 and C-64/00, Booker Aquaculture Ltd, Hydro Seafood GSP Ltd and the Scottish Ministers, [2003] ECR, I-7411 at para. 65. See also cases 4/73, ECR 1974, 491 and 44/79, [1979] ECR 3727.

${ }^{16}$ G.A. res. 217A (III), UN Doc. A/810 at $71(1948)$.

17 G.A. res. 2200A (XXI); UN Doc. A/6316, 999 UNTS 171. On this article, see Schneider, Menschenrechtlicher Schutz geistigen Eigentums, Reichweite und Grenzen des Schutzes geistigen Eigentums gemäß Artikel 15 Absatz 1 lit. c) des Internationalen Paktes über wirtschaftliche, soziale und kulturelle Rechte (2006). 
anteeing creators a just remuneration for their work, which makes these judicial instruments particularly modern and flexible means to regulate this matter ${ }^{18}$.

The European Convention on Human Rights (ECHR $)^{19}$ does not have a specific provision on intellectual property ${ }^{20}$. It does, however, codify the principle of freedom of expression and communication in Art. 10(1)and Art. 10(2) provides for restrictions on the protection of the rights of others, which includes the rights of creators ${ }^{21}$. Furthermore, even though intellectual property is not explicitly named, there is no longer any doubt that the exploitation right is also protected by Art. 1 of Protocol 1 of the Convention, which protects property ${ }^{22}$. This has been clearly stated in recent case law of the European Court of Human Rights $^{23}$. In relation to moral rights, although there is no case law on them yet, legal scholars are of the opinion that these rights might be protected by Art. 8 of the Convention on the protection of privacy, ${ }^{24}$ or even by Art. 10(1) which protects freedom of expression ${ }^{25}$. Thus, the classical foundations for intellectual property can be found in these texts, ${ }^{26}$ where they are carefully balanced: on the one hand, such rights are founded in natural law through the acknowledgement of an exploitation right and a "droit moral" for the creator; and on the other

${ }^{18}$ See also in this sense Mylly, Intellectual Property and Fundamental Rights: Do they Interoperate?, in: Bruun (ed.), Intellectual Property Beyond Rights (2005), p. 197.

${ }_{19}$ ETS No. 005 (Vol. I).

${ }^{20}$ In favour of a formal recognition of author's rights at the constitutional level (especially in the ECHR), see also Zollinger, Droit d'auteur et droits de l'Homme (2008), p. 160.

21 This is generally admitted. See in this sense, for example, Voorhoof, La liberté d'expression est-elle un argument légitime en faveur du non respect du droit d'auteur?, in: Strowel/ Tulkens (eds.), Droit d'auteur et liberté d'expression (2006), p. 55.

22 See e.g. Wegener, Economic Fundamental Rights, in: Ehlers (ed.), European Fundamental Rights and Freedoms (2007), p. 135; Coban, Protection of Property Rights within the European Convention on Human Rights (2004), p. 149; Carss-Frisk, The Right to Property, A guide to the implementation of Art. 1 of Protocol No. 1 to the European Convention on Human Rights, in: Human rights handbooks No. 4 (2001), p. 6. According to Drexl, Constitutional Protection of Authors' Moral Rights in the European Union - Between Privacy, Property and the Regulation of the Economy, in: Ziegler (ed.), Human Rights and Private Law, Privacy as Autonomy, (2007), p. 159, this article could even protect moral rights with a "property-based" approach to these rights. In any case, according to this author, moral rights would be protected by Art.17(2) of the Charter of Fundamental Rights of the European Union.

23 See e.g. ECHR, Anheuser Busch Inc. v. Portugal, (supra, note 9): "Intellectual property as such undeniably attracts the protection of Art. 1 of Protocol No. 1" (trade mark case). See also, in the field of patent law, the decision Smith Kline and French Laboratories Ltd. v. The Netherlands, and in the field of copyright law ECHR, $4^{\text {th }}$ section, Balan v. Moldova (supra, note 8).

${ }^{24}$ Hugenholtz, Copyright and Freedom of Expression in Europe, in: Dreyfuss/Zimmermann/First (eds.) (supra, note 13), p. 346, and, more prudently, Drexl (supra, note 22).

${ }_{25}$ Leuprecht, Droit d'auteur et droits de l'homme au plan européen, in: Droits d'auteur et droits de l'homme (1990), p. 66.

${ }^{26}$ On the sources of human rights in general, see Shestack, The Philosophical Foundations of Human Rights, in: Symonides (ed.), Human Rights: Concept and Standards (2000), p. 31. 
hand, they also have a utilitarian foundation because the acknowledged rights have the goal of promoting intellectual variety and promulgating culture and science within society. ${ }^{27}$

Of course, it is often emphasised that the UDHR is not binding, since it is only a recommendation of the United Nations General Assembly. Nevertheless, many authors consider that the declaration exerts a binding effect as customary international law. ${ }^{28}$ In some decisions in France, the UDHR has even been directly applied in copyright disputes. ${ }^{29}$ Also, the lack of a binding effect of the declaration is irrelevant in those countries that have ratified UN agreements because, as international treaties, they are binding on the states that acceded to them (which does not include the US!). The same applies in Europe to the European Convention on Human Rights. Meanwhile, as we have already underlined, the application of the Convention is even recognised in private-law disputes in many countries, so that without doubt a fundamental rights reasoning has entered into private-law discourse $\mathrm{e}^{30}$. There are many cases in which national judges have applied the ECHR horizontally, that is, in conflicts between two private persons. Moreover, the values protected in the ECHR are also included in national constitutions. While only few countries in Europe mention intellectual property (mostly copyright) at the constitutional level ${ }^{31}$, all provide

27 Torremans, Copyright as a Human Right, in: Torremans (ed.), Copyright and Human Rights (2004), p. 7, reprinted in an extended version with the title "Copyright (and Other Intellectual Property Rights) as a Human Right”, in: Torremans (ed.), Intellectual Property and Human Rights (2008), p. 195. See also Dietz, Constitutional and Quasi-Constitutional Clauses for Justification of Authors' Rights (Copyright) - From Past to Future, in: The Sources of Copyright - Proceedings of the ALAI Congress 2005 (2007), p. 55. This author drafts an interesting, balanced proposition of a constitutional clause on copyright protection, which could be included in the national constitutions of the different European countries.

28 See e.g. Dock, Les conventions internationales sur le droit d'auteur et la Déclaration universelle des droits de l'homme, in: Droits d'auteur et droits de l'homme, (1990), p. 90; Bécourt, Copyright and Human Rights, 32 Copyright Bulletin 14 (1998); Telec, The Human Rights Dimension of Authors' Rights and Neighbouring Rights from the Czech Constitutional Perspective, in: Ganea/Heath/Schricker (eds.), Festschrift für A. Dietz (2001), p. 76.

29 See e.g. Paris District Court, 29 April 1959, 28 RIDA 133 (1960); Paris District Court, 23 November 1988, 139 RIDA 205 (1989); Paris Court of Appeal, 1 February 1989, 142 RIDA 301 (1989), comment by Sirinelli.

30 According to one scholar, in the future there will be a tendency to emphasize the direct applicability of all fundamental provisions of the new European legal order, therefore allowing private individuals to complain about the behavior of other private entities which could appear to be in violation of human rights. Why then should the Universal Declaration of $\mathrm{Hu}-$ man Rights not benefit from the direct applicability of the European Convention on Human Rights?" (Dessemontet, Copyright and Human Rights, in: Kabel/Mom (eds.), Intellectual property and information law (1998), p. 116. In fact, we have already underlined that according to the ECJ, the UDHR and the ICESCR are also part of the European framework concerning fundamental rights and have to be taken into account.

31 See e.g. Art. 42(2) of the Portuguese Constitution; Chapter 2, Sec. 19 of the Swedish Constitution; Art. 43(1) of the Slovakian Constitution; Art. 60 of the Slovenian Constitution; 
equally for the protection of property and personality rights on the one hand, and the protection of freedom of expression, freedom of information and freedom of the arts and sciences on the other hand.

In summary, fundamental rights and human rights are a synthesis of the bases of natural law and utilitarianism and represent the values from which intellectual property has developed. ${ }^{32}$ As Audrey Chapman stated, "a humanrights approach takes the implicit balance between the rights of inventors and creators and the interest of the wider society within intellectual property paradigms and make it more explicit and exacting. A human-rights orientation is predicated on the centrality of protecting and nurturing human dignity and the common good. By extension, the right of the creator or the author are conditional on contributing to the common good and welfare of society" (emphasis added $)^{33}$. It can therefore be concluded that fundamental rights offer common principles and a balanced framework for intellectual property law in the European Union.

One notable exception can perhaps be found in the wording of the Charter of Fundamental Rights of the European Union, which simply states in Art. 17(2) that: "intellectual property shall be protected" 34 . According to this article, intellectual property seems to stand as an end in itself and is not linked to the fulfilment of a certain function. Furthermore, the protection granted is not even specifically given to the creator. While all the other articles of the Charter commence with "Everyone has the right to...", Art. 17(2) does not. Does this mean that investors could also claim protection under this article? If this is so, this would be a sign of a real paradigm shift for intellectual property law, as the investment (and not the creative input) would become the main justification for granting protection. Of course, this would still be in line with Art. 1 of Protocol

Art. 34 of the Czech Charta on Fundamental Rights; Art. 44(1) of the Russian Constitution. However, as was rightly stated by Dietz (supra, note 27), none of these clauses is really drafted in a satisfactory manner.

32 See Drahos, Intellectual Property and Human Rights, [1999] IPQ 349; Cornides, Human Rights and Intellectual Property, Conflict or Convergence?, 7 Journal of World Intellectual Property 138 (2004), underlining the instrumental dimension of human rights regarding intellectual property.

${ }_{33}$ Chapman, Approaching Intellectual Property as a Human Right (obligations related to Art. 15(1)(c)", 35 Copyright Bulletin 14 (2001). See also Anderson/Wager, Human Rights, Development, and the WTO: The Cases of Intellectual Property and Competition Policy", 9 Journal of International Economic Law 721 (2006), underlining that human rights and utilitarian rationales are not mutually exclusive, but are complementary grounds for the protection of IPRs.

34 On this provision see Geiger, Intellectual Property shall be protected!? Art. 17(2) of the Charter of Fundamental Rights of the European Union: a Mysterious Provision with an Unclear Scope, [2009] EIPR 113; Griffiths/McDonagh, Fundamental Rights and European IP Law - The Case of Art 17(2) of the EU Charter, in: Geiger (ed), Constructing European Intellectual Property: Achievements and New Perspectives, forthcoming 2012. 
1 of the European Convention which states that "every natural or legal person is entitled to the peaceful enjoyment of his possession" and therefore authorizes the adjudication of property right claims by legal persons and business entities. But this would be contrary to the spirit of UDHR and the ICESCR, where the requirement of human creativity "indicates that persons other than the initial creator of the subject matter may be outside the scope of protection guaranteed by these Articles" 35 .

On the other hand, the special mention of intellectual property alongside the general property right could also be interpreted as a mark of its specificity. IP might then be mentioned separately because of its difference from the right to property in general, as it concerns property of a special kind, a property that is "socially rooted", in accordance with the theory of the social function of intellectual property rights ${ }^{36}$. The problem is that Art. 17(2) unlike Art. 17(1), which states that "the use of property may be regulated by law in so far as necessary for the general interest" contains no limitations ${ }^{37}$. Anyhow, commentators have considered that the limitations on the general right to property contained in Art. 17(1) must apply equally to intellectual property ${ }^{38}$. This is clearly confirmed by the preparatory document, as the Explanations relating to the Charter

${ }^{35}$ Mylly (supra, note 18), p. 196; Ricketson, Intellectual Property and Human Rights, in: Bottomley/Kinley (eds.), Commercial Law and Human Rights (2001), p. 192 and the General Comment No. 17 (2005) of the United Nations Committee on Economic, Social and Cultural Rights to Art.15(1)(c) of the Covenant (E/C.12/GC/17, 12 January 2006), stating that "the Committee considers that only the 'author', namely the creator, whether man or woman, individual or group of individuals, of scientific, literary or artistic productions, such as, inter alia, writers and artists, can be beneficiary of the protection of Art. 15(1)(c)... The drafters of this article seemed to have believed authors of scientific, literary or artistic productions to be natural persons" (para. 7). See on this comment Haugen, General Comment No. 17 on 'Authors' Rights", 10 The Journal of World Intellectual Property 53 (2007).

${ }^{36}$ On the theory of the social function of intellectual property, see also more recently Leinemann, Die Sozialbindung des Geistigen Eigentums (1998), and for copyright, Pabud, Die Sozialbindung des Urheberrechts (2000); Geiger, La fonction sociale des droits de propriété intellectuelle, 210 Recueil Dalloz (D.) 510; Rocha de Souza, A função social dos direitos autorais: uma interpretaçao civil-constitucional dos limites da proteção juridical: Brasil: 1888-2005 (2006). On the social function of the general right to property see recently Libchaber, La propriété, droit fondamental, in: Cabrillac/Frison-Roche/Revet (eds.), Libertés et droits fondamentaux (2006), p. 659, according to whom the right to property has changed from an individualistic right - i.e. assigned only for the egotistical purposes of the proprietor - to a sort of social function: the property is no longer restricted to the aspect of personal development, which it permits, but is also considered from the perspective of the interests of society.

37 On the social function of property in Art. 17 of the Charter, see Callies, The Fundamental Right to Property", in: Ehlers (ed.), European Fundamental Rights and Freedoms (supra, note 22), p. 456, stating that the social function "serves as a justification for and limitation of the restrictions imposed on property utilisation".

38 See e.g. Mylly (supra, note 18), p. 207; Depenheuer, in: Tettinger/Stern (eds.), Kölner Gemeinschaftskommentar zur Europäischen Grundrechtscharta (2006), Art. 17, para. 29. 
of Fundamental Rights on Art. 17 state that intellectual property is "one aspect of the right of property" and is only mentioned separately because of "its growing importance in Community secondary legislation (...) The guarantees as laid down in paragraph 1 shall apply as appropriate to intellectual property" ${ }^{39}$. In any case, it would have been much better to underline the limited character of intellectual property explicitly to prevent any abusive interpretations, by introducing a balanced constitutional clause on intellectual property in the Charter that is modelled on the Universal Declaration ${ }^{40}$. At any rate, it should not be forgotten that the Charter also provides for the protection of other fundamental rights that equally have to be taken into account (for example, Art. 11: Freedom of expression and Information; Art. 13: Freedom of the Arts and Sciences; Art. 7: Respect for private life; and even Art. 15 and 16 Freedom to choose an occupation and to conduct a business might be concerned). The principle of proportionality laid down by Art. 52 Para. 1 of the Charter, in particular, requires a balancing of intellectual property rights with competing rights.

\section{Consequences for Intellectual Property Law}

Opponents to any fundamental-rights discourse within intellectual property law often argue that these rights are vague and do not allow any conclusions to be drawn concerning the scope of intellectual property rights - that such discourse is merely a theoretical exercise that does not have any practical implications. In our opinion, the contrary is true and hereafter we will try to demonstrate that the constitutional framework has numerous practical consequences at the EU level ${ }^{41}$, especially in offering common principles and providing the condition for well balanced IP-legislation ${ }^{42}$. This positive effect can be illustrated by

39 Explanations relating to the Charter of Fundamental Rights (2007/C 303/02).

${ }^{40}$ For such a clause see also Dietz (supra, note 27); Geiger (supra, note 11), p. 385.

${ }^{41}$ See in this sense Torremans (supra, note 27), p. 19, and Drexl, (supra, note 22), stating that "constitutional considerations matter. They are crucial for building a legal system in a situation in which there is a growing feeling that something is wrong with existing copyright". See also Porsdam, On European Narratives of Human Rights and Their Possible Implications for Copyright, in: Macmillan (ed.), New Directions in Copyright Law, Vol. 6 (2007), p. 335.

42 See also in this sense Helfer, Towards A Human Rights Framework for Intellectual Property, 40 U.C. Davis L Rev. 971 (2007); Geiger, Copyright and Free Access to Information, For a Fair Balance of Interests in a Globalized World, [2006] EIPR 366. On the relationship of intellectual property and human rights in general, see $Y u$, Reconceptualizing Intellectual Property Interests in a Human Rights Framework, 40 U.C. Davis L. Rev. 1039 (2007); Bronzo, Propriété intellectuelle et droits fondamentaux (2007); Seuba, Human Rights and Intellectual Property, in: Correa/Yusuf (eds.), Intellectual Property and International Trade: The TRIPS Agreement, $2^{\text {nd }}$ ed. (2008), p. 387; Brown, A legal solution to a real problem: the interface between intellectual property, competition and human rights, $\mathrm{PhD}$ Thesis, University of Edinburgh (2008); Mylly, Intellectual Property and European Economic Constitu- 
considering the application of fundamental rights by various European national courts in numerous cases, ${ }^{43}$ to operate as a shield against some of the overprotective tendencies of intellectual property and securing the coherence which the law (or its understanding) seems to have lost lately. ${ }^{44}$

In fact, there are several consequences for intellectual property legislation attached to the constitutional framework of fundamental rights at the EU level. First, fundamental rights are included in the national constitutions and bind the legislature. They rank highly in the hierarchy of norms. Therefore, reference to natural law is no longer necessary because the basis of natural-law values has been codified in fundamental rights. ${ }^{45}$ This is not unimportant, especially for copyright discourse, as natural law, because of its vagueness, might be very easily misused and has often been manipulated in the past to justify a systematic extension of the scope of protection. ${ }^{46}$ Fundamental rights form the roots of positive law and ought to be considered by lawmakers. ${ }^{47}$ They offer possibilities for a balanced development of intellectual property.

Secondly, the legislature should consider all fundamental rights equally: there is no hierarchical relationship between them. There is a basic tension between property and freedom, which the legislature must bring into a balanced relationship..$^{48}$ The property right and the personality right ${ }^{49}$ must therefore always be confronted by different fundamental rights like freedom of expression,

tional Law (2009); Grosheide (ed.), Intellectual Property Rights and Human rights: A Paradox (2010); Helfer/Austin, Human Rights and Intellectual Property: Mapping the Global Interface, 2011.

43 On the consequences see also Brown, Guarding the guards: The practical impact of human rights on protection of innovation and creativity, paper presented at the $20^{\text {th }}$ BILETA Conference, April 2005, Queen's University of Belfast, and from the same author: Human rights: in the real world, [2006] JIPLP 603.

${ }^{44}$ Geiger, Fundamental Rights, a Safeguard for the Coherence of Intellectual Property Law?, 35 IIC 268 (2004).

${ }^{45}$ Fechner, Geistiges Eigentum und Verfassung (1999), p. 135.

46 See in this sense Vivant, Le contenu du droit d'auteur, in: De Lamberterie (ed.), Le droit d'auteur aujourd'hui (1991), 83.

47 See Mylly (supra, note 18), pp. 187 et seq., underlining that fundamental rights "provide the basic set of the most fundamental norms and principles to which all areas of law are connected. They thus play a particular role in the pursuit of coherence (...). Accordingly, private law and fundamental rights should be seen in a dialogical relationship: rather than eliminating choice, autonomy and experimentalism, such a dialogue enables the realisation of certain basic values". See also from the same author: Intellectual Property and European Economic Constitutional Law (2009), pp. 200 et seq.

48 See also in this sense Vaver, Intellectual Property: The State of the Art, (2000) $116 \mathrm{LQR}$ 636; Ricketson, (supra, note 35), p. 192; Cornides (supra, note 32), p. 167.

49 The link between the moral right and the personality right is very clear in Germany, where moral rights are described as "authors' personality rights" (Urheberpersönlichkeitsrechte). See on this issue Drexl, (supra, note 22). On the constitutional protection of copyright in Germany see Geiger, Droit d'auteur et droit du public à l'information, approche de droit comparé (2004), pp. 142 et seq. 
freedom of information and the right of privacy, and a proportional balance between these rights must be found. ${ }^{50}$

Furthermore, not only national, but also European legislature is bound by fundamental rights. As we have seen, ECHR rights are considered to be general principles of European Union law and have a higher status in the European hierarchy of norms than directives. ${ }^{51}$ As according to the new version of Art. 6 (2) of the EU Treaty, the Union will accede to the ECHR, the Convention can thus be considered to be the highest binding source of law within the Community concerning fundamental rights, so that both primary and secondary EC legislation must comply with it. ${ }^{52}$ Directives should therefore always be interpreted "in the light" of the European Convention. The Court of Justice of the European Union (CJEU) has clearly shown in its Promusicae decision that fundamental rights ought to be taken very seriously when interpreting European Union $\mathrm{law}^{53}$. In fact, according to the Court, European Union law requires that, when transposing directives, "the Member States take care to rely on an interpretation of them which allows a fair balance to be struck between the various fundamental rights protected by the Community legal order. Further, when implementing the measures transposing those directives, the authorities and courts of the Member States must not only interpret their national law in a manner consistent with those directives but also make sure that they do not rely on an interpretation of them which would be in conflict with those fundamental rights or with the other general principles of Community law, such as the principle of proportionality" 54 .

50 See also Torremans (supra, note 27), p. 17; Grünberger, A Constitutional Duty to Protect the Rights of Performers? Goldstein versus California and Bob Dylan - Two Different Stories, 37 IIC 277 (2006). More sceptical Ostergard, Intellectual Property: A Universal Human Right?, 21 Human Rights Quarterly 156 (1999), arguing that to recognise IPRs as human rights is problematic because other human rights, like those relating to physical well-being, must take priority over the guarantee of IPRs as universal human rights. In our opinion, to recognize IPRs as human rights does not mean to give priority to these rights over those relating to physical well-being. On the contrary, it might even require that the latter prevail, because fundamental rights are always to be analysed in their interaction with other fundamental rights. Art. 27(2) UDHR, for example, should always be contemplated with regard to Art. 27(1).

51 ECJ, case 4/73, [1974] ECR 491; see also Art. 6(2) EU, which in its modified version (Treaty of Lisbon) becomes Art. 6(3).

52 See Scheer, The Interaction between the ECHR and EC Law, A Case Study in the Field of EC Competition Law, ZEuS 2004, 690. As a result, in a subordination of EC law to the ECHR, the EC institutions should be considered bound by the ECHR. See also the modified version of Art. 6(2) EU; Art. 51(1) Charter of Fundamental Rights of the European Union.

${ }^{53}$ ECJ, case C-275/06, Promusicae v. Telefónica de España SAU, para. 70. On this decision see Davies/Helmer, Productores de Música de España (“Promusicae”) v. Telefónica de España SAU (“Telefónica”) (C-275/06), [2008] EIPR 2008307.

${ }^{54}$ Emphasis added. 
In addition, as already mentioned, there have been increasing references to fundamental-rights values in the recitals of the latest directives on intellectual property, which must also be considered when interpreting these texts. ${ }^{55}$ The obligation to interpret EU law in a manner compliant with fundamental rights, however, is not restricted to directives, but also extends to the whole acquis communautaire, including the articles of the EU Treaty. ${ }^{56}$ National legislatures have also, when implementing the directives, to take into account European standards of fundamental rights, ${ }^{57}$ as well as the provisions of their national constitutions, when the directives leave some margin of appreciation..$^{58}$ Fundamental rights, therefore, constitute a good framework for the development of intellectual property protection. They are effective tools to guarantee a balanced development and understanding of IP rights and a remedy for the overprotective tendencies of lobby-driven legislation ${ }^{59}$.

Finally, fundamental rights and human rights represent ethical values which enjoy acceptance and approval in European and international law. ${ }^{60} \mathrm{In}$ the context of globalisation, they offer a "human" legal framework for the advancement of intellectual property, which so far has been regarded exclusively from an economic point of view. ${ }^{61}$ Whereas, for instance, different legal systems show

55 See supra, note 7.

56 See e.g. the decision of the ECJ (case C-260/89, [1991] ECR I-2925) in which the court interprets the freedom to provide services in the light of the general principle of freedom of expression as embodied in Art. 10 of the ECHR. For the use of fundamental rights as mandatory requirements that justify barriers to the fundamental freedoms, see also cases C-368/95, [1997] ECR I-3689 and C-60/00, [2000] ECR I-6297. The arrival at the ECJ, as a result of the enlargement of the European Union of 1 May 2004, of a certain number of judges who have been part of either the European Court of Human Rights or a Constitutional Court could increase the influence of fundamental rights on the jurisprudence of the Court of Luxembourg (in this sense see Laurin, L'Europe à vingt-cinq et la Cour de justice de Luxembourg, 2006 D. 313).

${ }^{57}$ Craig/De Burca, EU Law. Texts, Cases and Materials, $3^{\text {rd }}$ ed. (2003), pp. 337 et seq. See in this sense the decision of the ECJ, case C-275/06, Promusicae v. Telefónica de España SAU, Case C-275/06.

58 See e.g. the decision of the German Constitutional Court, EuGRZ 1989, 339, 340: "The directive ... leaves ... a considerable margin of appreciation. The national legislature, when implementing the directive, is bound by the guidelines of the German Basic Law". This has also been clarified recently in Germany by the German Constitutional Court in the context of a framework decision of 18 July 2005, NJW 2005, 2289.

59 See in this sense Grünberger (supra, note 50), p. 302, stating that if a fundamental rights analysis of IP-Law "at first sight appears to be another twist to fortify the stronghold of right holders", it "may well turn out to be the critics Trojan horse in the industry's citadel".

60 Cassin, L'intégration, parmi les droits fondamentaux de l'homme, des droits des créateurs des œuvres de l'esprit, in: Mélanges Marcel Plaisant (1960), p. 231.

${ }^{61}$ In this sense also Drabos (supra, note 32); Chapman (supra, note 33), pp. 14 et seq.; Kéréver, Authors' rights are human rights, (1998) 32 Copyright Bulletin 23; Torremans (supra, note 27), p. 16; Geiger, 'Humanising' the IP System: Fundamental rights as tools to preserve a fair balance within intellectual property, Paper presented at the University of Oxford, UK, 24 November 2009. 
various cultural differences despite their convergences, the moral and cultural values of fundamental rights (as included for example in the UDHR) are undisputed and could even represent a basis for worldwide harmonisation. ${ }^{62}$ Therefore, it is possible to go one step further and assume that fundamental rights offer common principles, not only for European intellectual property, but also for global, international intellectual property rules. It is true that the EU as a member of the WTO is also bound by the TRIPS Agreement, so that primary and secondary EU legislation has to comply with it. This would mean the priority of trade law over European fundamental rights provisions. One should not forget, however, that the TRIPS-Agreement itself should be interpreted in the light of the UDHR. According to some scholars, this results in the primacy of international human rights acts over trade liberalisation rules ${ }^{63}$. Furthermore, the interpretation of TRIPS in the light of the UDHR may follow from the General Rule of interpretation of treaties found in Art. 31 of the Vienna Convention on the Law of Treaties of 23 May 1969, which entered into force on 27 January $1980^{64}$. According to Art. 31.3(c), when interpretating a treaty, "any relevant rules of international law applicable in the relations between the parties" should be taken into account. Given the numerous ethical questions involved, it is difficult to deny that the UDHR might be particularly relevant in the context of the TRIPS Agreement. In any case, in the interests of clarification, it would be worth considering including an explicit reference to the UDHR in any future review ${ }^{65}$. This might prevent a systematic interpretation in favour of right owners. Furthermore, it would guarantee that economic reasoning is carried

${ }^{62}$ See also in this sense Beldiman, Fundamental Rights, Author's Right and Copyright Commonalities or Divergences?, 29 Columbia Journal of Law \& the Arts 60 (2005).

63 See e.g. the article of G. Marceau, Counsellor for the Legal Affairs Division of the WTO Secretariat: WTO Dispute Settlement and Human Rights, 13 European Journal of International Law 753 (2002), and from the same author: The WTO Dispute Settlement and Human Rights, in: Abbott/Breining-Kaufmann/Cottier (eds.), International Trade and Human Rights: Foundations and Conceptual Issues, World Trade Forum, Vol. 5 (2005), chapter 10; Howse/Mutua, Protecting Human Rights in a Global Economy: Challenges for the World Trade Organization (2000).

${ }^{64}$ United Nations, Treaty Series, Vol. 1155, 331.

65 See Resolution 2000/7 of the UN Sub-Commission on Human Rights, 17 August 2000, on "Intellectual Property Rights and Human Rights" (E/CN.4/SUB.2/RES/2000/7), where the "Human Rights Commission requests the World Trade Organization, in general, and the Council on TRIPS during its ongoing review of the TRIPS Agreement, in particular, to take fully into account the existing State obligations under international human rights instruments." (emphasis added) See also in this sense Resolution 2001/21 of the UN Sub-Commission on Human Rights, 16 August 2001 (E/CN.4/SUB.2/RES/2001/21). Unfortunately, these resolutions have no binding character for the Member States, but their political significance is not to be neglected. Furthermore, it is not excluded that these soft law principles evolve into customary international law (see e.g. Chinkin, The Challenge of Soft Law: Development and Change in International Law, (1989) 38 ICLQ 856. 
out with ethical considerations in mind. ${ }^{66}$ Such a clarification could be incorporated into a protocol to the TRIPS Agreement without substantial changes and could even result in the production of a consensus on an international level. ${ }^{67}$

All these developments lead to the following consequence: if legislation does not represent the values incorporated in constitutional provisions, judges have to interpret laws in the light of fundamental rights. In exceptional cases, they can even intervene without legal basis within IP law to correct certain excesses $^{68}$. As has been previously stressed, in numerous decisions of European courts, the rights laid out in the ECHR or in national constitutions have already been used in IP disputes to limit the exclusive rights of right owners (in these cases, fundamental rights act as “external” limits on intellectual property).

\section{Conclusion}

In conclusion, one can say that the European framework concerning Fundamental Rights could guarantee a well-balanced development of European legislation ${ }^{69}$. It may also allow judges to step in and correct certain excesses when

66 See Chapman (supra, note 33), p. 15. See also Kur, A New Framework for Intellectual Property Law - Horizontal Issues, 35 IIC 14 (2004), underlining the need to take ethical issues more into account.

${ }^{67}$ Favoring a link of the TRIPS Agreement to the human rights treaties, see also Helfer, Human Rights and Intellectual Property: Conflict or Coexistence?, 5 Minn. Intell. Prop. Rev. 61 (2003). This author maintains that allowing greater opportunities for airing a human-rights perspective on intellectual property issues will strengthen the legitimacy of the WTO and promote the integration of an increasingly dense thicket of legal rules governing the same broad subject matter. See also Anderson/Wager (supra, note 33), pp. 707 et sq., underlining the complementarities of international trade law with human rights concerns: "It remains that efficiently functioning markets, backed up by appropriate laws and institutions, are central to any realistic programme for development and hence to the fulfillment of human rights" (at 715).

68 The so called "Three-Step Test" incorporated in the international and European legal order (Art. 9.2 of the Berne Convention, Art. 13 TRIPS, and Art. 10 WCT and Art. 16 WPPT, Art. 5(5) of the Directive of 22 May 2001 on Copyright and Neighbouring Rights in the Information Society) might in the future be a direct "entrance door" for fundamental rights reasoning in copyright law, therefore allowing judges to apply copyright limitations in a more flexible way (see Geiger, Flexibilising Copyright, 38 IIC 178 et seq. (2008)). In fact, the third step of the test deals with the justification that underlies the limitation. According to it, application of limits to copyright must not be to any "unjustified" disadvantage of the copyright owner. The rationale is that the author should not be in the position to control all sorts of use of his work, but he has to tolerate certain interferences as long as they are justified by values that are superior to the copyright owner's interests. This formula will thus enable the judge to apply a control of proportionality and balance the different fundamental rights involved (see Geiger, The Role of the Three-Step Test in the Adaptation of Copyright Law to the Information Society, e-Copyright Bulletin, January-March 2007).

${ }^{69}$ On the concept of the balancing of interests in copyright legislation, see Hilty/Geiger (eds.) The Balance of Interests in Copyright Law, Proceedings of the Conference organized 
sight has been lost of basic values of intellectual property. Fundamental rights can, therefore, very usefully be employed as common principles for the development of IP at the European and international level, also having the potential to aid intellectual property to overcome the serious crisis of legitimacy that it is facing at present in public opinion. Therefore, on the contrary, far from being something to be feared, fundamental rights reasoning seems to be highly desirable 70 and should be encouraged and developed in Europe and internationally at any level, be it legislative, judicial, or in future scholarly work.

by the Max Planck Institute for Intellectual Property in Berlin in November 2004 (2006), online publication to be found at: www.intellecprop.mpg.de/ww/de/pub/forschung/publika tionen/online_publikationen.cfm

70 More detail on the complementarity of fundamental rights and IP, see Geiger, Propriété intellectuelle et droits fondamentaux: une saine complémentarité, in : Droits de propriété intellectuelle, Liber amicorum Georges Bonet (2010), p. 249. 
IV. Intellectual Property and Competition 



\title{
The Interface between Intellectual Property Rights and EU Competition Law
}

\author{
Steven Anderman
}

\section{Introduction}

EU competition law now regulates the exercise of intellectual property rights (IPRs) over an increasingly wider front. New cases in the information technology sector under Article 102 TFEU have targeted abuses of a dominant position such as price discrimination ${ }^{1}$ and unfair pricing as well as refusals to license and tying and bundling. ${ }^{2}$ The pharmaceutical industry has offered cases of misuse of the patent system as an abuse of dominance, ${ }^{3}$ as well as suggesting a capacity to infringe Article $101 \mathrm{TFEU}$ with reverse or delay payments, both aiming to prevent the entrance of generics into existing markets. ${ }^{4}$ The field of standard setting and technology pools has attracted the attention of the competition authorities not only because of cases of patent ambush ${ }^{5}$ and FRAND ambush ${ }^{6}$ but also because of competition concerns with the process of selecting patented technologies for industrial standards. These forms of collaboration amongst competitors as well as that of licensing collection societies, have been examined by the European Commission under Articles 101 as well as 102 TFEU. Finally, the modernization of Article 101 TFEU has produced new detailed guidelines

${ }^{1}$ See Case COMP/37.990 Intel, Commission Decision of 13 May 2009 (D(2009) 3726 final) ('Intel').

${ }^{2}$ CFI, Case T-201/04, Microsoft Corp. v. Commission, [2007] ECR II-3601 ('Microsoft').

${ }^{3}$ General Court, Case T-321/05, Astra Zeneca v. Commission ('Astra Zeneca'). See also the recent Boebringer case being investigated by the Commission to determine whether Boehringer misused patents to exclude competitors. The Commission's charges concerned "misuse of the patent system in order to exclude potential competition in the area of chronic obstructive pulmonary disease (COPD) drugs".

${ }^{4}$ European Commission Pharmaceutical Sector Inquiry Final Report (8 July 2009) $<$ http://ec.europa.eu/competition/sectors/pharmaceuticals/inquiry/staff_working_paper_ part1.pdf $>$ accessed 8 July 2010 ('Sector Inquiry Report').

${ }^{5}$ EC Notice on Acceptance of Commitments in Case IP/09/1897 Rambus (9 December 2009).

6 See 'Antitrust: Commission welcomes IPCom's public FRAND declaration', MEMO/09/549 (10 December 2009). IPCom's s role in the UMTS pool after its belated acceptance that it was bound by its predecessor's commitment to a FRAND license of essential patents. 
and block exemptions for R\&D and specialization agreements and IP licensing agreements in the form of technology transfers.

This pattern of competition law enforcement is first of all a reminder that the new competition rules are a development of an existing 'second tier' of regulation of the exercise of IPRs, an 'external' system of regulation that applies to anti-competitive conduct not prevented by the 'internal' system of regulation offered by IP legislation. ${ }^{7}$ All IPRs have a system of protection that balances the exclusivity granted to 'pioneer' inventors and creators with the limits and exceptions in favour of 'follow on' innovators. However, the limits of permitted exercise of IPRs are drawn not only by the laws of IP but also by reference to the rules of competition law.

When the competition rules apply to the exercise of IPRs, they apply as a separate system according to their own logic. They treat the exercise of an IPR, once granted, as any other private tangible right, subject to the public law limits on market behaviour created by the competition rules. On closer inspection, the logic of competition law reveals a predisposition to accommodations to the exercise of IPRs. In addition to some limited special concessions such as the exceptional circumstances rule for refusals to licence, the very design of the general competition rules leaves room for the 'normal' exercise of IPRs and focuses on the cases where their exercise happens to coincide with extreme forms of commercial conduct.

The reasons for this are not far to seek. In the first place, there is a natural overlap in the aims of the two fields of law. The exclusive rights created by IP laws provide an incentive to inventors to create substitute products within markets and new products which establish new markets. Similarly, IP licensing is a vehicle to enlarge exploitation of protected technologies and thereby create a wider diffusion of the new technology which either creates new markets or brings substitutes to existing markets. Finally, the internal rules of IP legislation prevent copying but in fact encourage 'competition by substitution's between 'follow on' innovators and 'pioneer' innovators. ' They do this both by offering exceptions to exclusive rights such as 'experimental use' in patent law and 'fair use' in copyright law during the period of protection and informational benefits to innovation during the period of protection as well as after the period of protection has expired. And of course, if there is weak market power associated with an IPR, its capacity to impose a restraint on competition or a barrier to entry is limited or non-existent.

\footnotetext{
7 See Rahnasto, Intellectual Property Rights, External Effects and Antitrust Law: Leveraging IPRs in the Communications Industry (2003).

8 A phrase originally coined by Ullrich and mentioned by Drexl, Is there a More Economic Approach to Intellectual Property and Competition Law?, in Drexl (ed), Research Handbook on Intellectual Property and Competition Law (2008).

${ }^{9}$ Of course almost every so called 'pioneer' innovator is itself a 'follow on' innovator.
} 
A second factor is that the competition rules are not meant to apply to the exercise of IPRs as such. They are only meant to apply when the IPR is used as an 'instrument' of abuse ${ }^{10}$ or as a means of restricting competition. ${ }^{11}$

On the whole, the modernization of the EU competition rules has improved their accommodation to the exercise of IPRs. The modern approach to abuse of dominance is based on a much more careful assessment of the actual market power of the legal monopolies conferred by patents and industrial copyright when these are used as part of corporate strategies. These legal 'monopolies' are now assessed entirely on the basis of their de facto market power. There were periods in the past, in both the USA and the EU, when the legal monopoly conferred by a patent in the form of a right to exclude anyone else from exploiting the patented invention was presumed to coincide with market power. This led to judicial and administrative competition rules which paid inadequate attention to the effects of IPRs upon investment in R\&D and innovation. This historical presumption has finally been replaced by a more appropriate judicial and administrative understanding that the actual market power associated with an IPR must be assessed empirically in each case.

Moreover, a new and more realistic economic approach has been introduced into the block exemption regulations and guidelines under Article 101 TFEU, reducing much of the substantive burden of regulation on IP licensing agreements between non-competitors as well as R\&D Joint Ventures and standardization agreements. The new TTBER regulation provides a 'safe harbor' and the TT Guidelines offer inter alia a new methodology to apply Article 101 TFEU to IP licensing agreements outside the safe harbour of the TTBER. This focuses regulation more carefully upon agreements in which the IP owning parties have or achieve real market power, and upon agreements between competitors thus significantly lessening the effect of the competition rules upon licensing agreements between non-competitors.

Despite all this, the actual number of confrontations between the owners of IP and the competition authorities and courts has been on the increase. Why has this been so? What accounts for this increase in regulatory confrontations when the overall framework has become more nuanced? Not surprisingly, the answer can be found in both sides of the equation: the conduct of the regulated and the actions of the regulator. On the one hand, IP owners have developed new and more aggressive commercial strategies in their exploitation of IPRs. On the other hand, it can be seen that regulatory authorities have adapted their techniques for measuring market power and defining abuse in response to recent developments in commercial practice involving IPRs.

10 See e.g. ECJ, case 102/77, Hoffman-La Roche v. Centrafarm, [1978] ECR 1139, para. 16.

11 See e.g. ECJ, case 262/81, Coditel v. Ciné-Vog Films, [1982] ECR 3381, para. 14 ('Coditel II'). 


\section{The New Commercial Strategies}

The first factor that has caused an increase in encounters between IPRs and the competition rules has been the noticeable rise in the strategic use of IPRs in new commercial practices. As corporations have developed a greater understanding of the value of their corporate intangible assets and have given a more realistic book value to their intangible assets, they have not only pursued more rigorous enforcement policies; they have found more imaginative uses for IPRs within their overall commercial strategies. Many of these strategies occur in a form that is legitimate profit taking and a lawful adaptation of commercial practice to commercial realities. Overall, a considerable amount of aggressive and imaginative commercialization of IPRs has long proved to be essentially compatible with 'competition on the merits' under the competition rules.

On the other hand, a number of new commercial practices by IP owners have been caught as prohibited exclusionary or exploitive abuses under the competition rules. The Microsoft ${ }^{12}$ case highlights the sensitivity of the competition authorities to vertical integration strategies aimed at capturing 'aftermarkets' by incumbent dominant firms in the information technology sector. The Intel ${ }^{13}$ case reminds of the limits to dominant firms engaging in anticompetitive discounting designed to create exclusivity in primary markets. The Astra Zeneca ${ }^{14}$ case raises the issue when a misuse of the patent process amounts to a violation of Article $102 \mathrm{TFEU}$. The emergence of strategic attempts to obtain greater than FRAND royalties through patent ambush ${ }^{15}$ and FRAND ambush ${ }^{16}$ in the context of patent pools and industrial standards has awakened the interest of the competition authorities to the possibility of anti-competitive aspects of those processes.

This competition interest has not only spread within the field of unilateral action but has been extended to various forms of bilateral and multilateral cooperation between competitors. The reverse payment settlements in the pharmaceutical sector have raised competition issues in the conduct of the pharmaceutical firms directed against competition by generic producers. Even before the Rambus case, the competition authorities had shown an interest in regulating the process of standard setting and R\&D joint ventures and that interest is currently intensifying. Finally there has been a renewed interest by the European

12 Microsoft (supra, note 2).

13 Intel (supra, note 1).

${ }_{14}$ Astra Zeneca (supra, note 3).

15 EC Notice on Acceptance of Commitments in Rambus case IP/09/1897 (9 December 2009).

16 See 'Antitrust: Commission welcomes IPCom's public FRAND declaration' (supra, note 6). 
Commission in collective licensing. The key feature of all these confrontations and investigations is the fact that the IP is used either as a component of market power or as a suspected instrument of the abuse in the chosen commercial strategy that leverages the dominance into abusive conduct.

\section{IPRs and the Logic of the Competition Rules}

As we have seen, the logic of the current rules of competition law embodies a far more nuanced understanding of the pro-competitive nature of IPRs. However, the way in which this plays out in its treatment of IPRs varies dramatically depending upon the constituent element of the competition prohibition being assessed. Thus, in the first stages of analysis of potentially anti-competitive conduct, the definition of relevant market and the assessment of dominance, there are few if any special concessions to IPRs. As we have seen, these stages consist of a factual analysis, assisted by economic reasoning, which is similar to the analysis of the market power of any other form of property. IPRs are assessed in terms of the extent to which they create real restrictions of competition in the form of barriers to entry or impediments to entry. At this stage IPRs are examined largely in terms of their factual contribution to market power and their innovative features are viewed almost entirely in this light. Consequently, even though there is no longer an assumption that a patent is automatically associated with market power, an IPR can be found to be associated with an asset that enjoys dominance in a market.

In contrast, in the definitions of abuse, there are more concessions to the innovative and pro-competitive features of IPRs within the logic of the norms of the competition rules. There is for example the 'exceptional circumstances' rule that applies to refusals to license an IPR. Moreover the application of general norm of Article 102(a) TFEU to the pricing of IPRs leaves room for IP asset pricing that takes into account investment risks as well as costs in the case of IPRs.

At the same time, however, there are other features of the current EU normative definition of abuse that have proved to be less receptive to sweeping IP procompetitive arguments. The concept of abuse under Article 102 TFEU tends to rely on per se rules of abuse to implement its regulatory norms. The logic of the EU competition rules is to protect effective competition in the here and now. The first consequence of this is that Article 102 TFEU has a low level test of effects as a constituent element of its concept of abuse of dominance. The Courts are reluctant to take into account speculative arguments about future events. The second and related consequence is that the Courts have tended to confine arguments based on the pro-competitive features of prohibited acts to the category of objective justifications rather than allow benefits to offset current harms 
in a more balanced way. ${ }^{17}$ This approach reduces the scope for arguments based on dynamic efficiency to operate as a defense in cases of alleged abuse in a way that might be possible in a 'rule of reason' style balancing exercise similar to that used in the USA. Thirdly, such an approach appears to make few concessions to the existence of the alternative remedies offered by the IP laws.

\section{Conclusions}

Whether EU competition law concentrates on condemning only the more extreme forms of anti-competitive use of IPRs leaving sufficient room for legitimate competition to breathe has become a controversial issue.

On the one hand, the Commission has expressed a desire to move to a more economic approach to the enforcement of Article 102 TFEU to help avoid errors in enforcement that lead to the innocent being found guilty of infringing the competition rules. However, while the Courts have proved to be receptive to a more economic approach to Articles 101 and 102 TFEU on certain issues they have in recent cases resisted a major alteration to their interpretations of the Treaty provisions in relation to abuse. Hence, the EU Courts would appear at this stage to be affirming that the values of the Treaty suggest that it is equally if not of greater importance to avoid cases where the infringers of the competition rules are found innocent. As long as this continues to be the case Article 102 TFEU will apply as a relatively robust limit to abuses of market power generally as well as that of IP owners.

17 Microsoft (supra, note 2). 


\title{
Misrepresentation and Misappropriation \\ Two Common Principles or Common 'Basic Moral Feelings' of Intellectual Property and Unfair Competition Law
}

\author{
Dirk Visser
}

In this article it is submitted that misrepresentation and misappropriation are the two most important common principles, or common 'basic moral feelings' of intellectual property and unfair competition law in Europe and elsewhere.

It is also fully acknowledged that free trade, free speech, anti-trust law, legal certainty and the general need to be able to use and take advantage of existing work and ingenuity of others, are vital countervailing principles which determine the very important limitations and exceptions in intellectual property and unfair competition law to a large extend. These vital countervailing principles, however, are not discussed here.

"The prophecies of what the courts will do in fact, and nothing more pretentious, are what I mean by the law."1

The difference between legal academics on the one hand and judges and legal advisors on the other, is that the latter actually have to decide cases or predict what these decisions are likely to be or going to be. In order to make decisions all people (including judges) ultimately need some kind of emotional conviction that they should make a particular choice. A feeling that in a certain case a certain decision is preferable. Without such a feeling a person cannot decide anything. In fact, it has been proven that people with a particular kind of brain damage which blocks their emotional mental capacities cannot decide any thing: they keep on weighing different possibilities against one another, without being able to decide. ${ }^{2}$

Thus, anyone who has to decide any thing, including judges, ultimately needs some kind of feeling of emotional conviction that makes them decide. Therefore, in this essay, the phrase 'common principles' is sometimes used interchangeably with common 'basic moral feelings' of intellectual property, because the author is convinced that there is an important moral-emotional side to rules and decisions in intellectual property law.

1 Holmes, Path of the Law, 10 Harv. L.R. 457, 460-61 (1897).

2 Damasio, Descartes' Error: Emotion, Reason and the Human Brain (1994). 


\section{Misrepresentation}

Misrepresentation is without doubt the less controversial of the two principles which will be discussed here.

Misrepresentation is the basis for the English tort of passing off and is based on the principle against deceit and the rules against cheating. Deceit and cheating destabilize human interaction and society. If there is no trust and if you can not rely on others, there can be no cooperation and no exchange of goods, services and ideas will take place.

"A man is not to sell his own goods under the pretence that they are the goods of another man. He cannot therefore be allowed to use names, marks, letters or other indicia, by which he may induce purchasers to believe, that the goods which he is selling are the manufacture of another person"3

Misrepresentation is the basis of the prohibition on creating confusion in all trade mark laws, regulations, directives and treaties. ${ }^{4}$ Misrepresentation is the basis of the prohibition on creating confusion in rules (including directives ${ }^{5}$ and treaties ${ }^{6}$ ) against unfair competition.

Misrepresentation is also an important basis of the rules against plagiarism. There can be little doubt that the prohibition of misrepresentation is a common (European or even universal) principle of IP and unfair competition law.

\section{Misappropriation}

Misappropriation is a concept which often occurs together with misrepresentation, but which is clearly distinct from it, because it typically does not require any misleading of, or confusion on the part of the public. In fact, for

${ }^{3}$ Lord Langdale MR in Perry v. Truefitt, (1842) 6 Beav. 66; 49 ER 749.

${ }^{4}$ Article 16 TRIPs.

5 Article 6 (2)(a) a of the Unfair Commercial Practices Directive reads as follows:

2. A commercial practice shall also be regarded as misleading if, in its factual context, taking account of all its features and circumstances, it causes or is likely to cause the average consumer to take a transactional decision that he would not have taken otherwise, and it involves: (a) any marketing of a product, including comparative advertising, which creates confusion with any products, trade marks, trade names or other distinguishing marks of a competitor.

${ }^{6}$ Article 10bis of the Paris Convention for the Protection of Industrial Property (Unfair Competition):

(1) The countries of the Union are bound to assure to nationals of such countries effective protection against unfair competition.

(2) Any act of competition contrary to honest practices in industrial or commercial matters constitutes an act of unfair competition.

(3) The following in particular shall be prohibited:

1. all acts of such a nature as to create confusion by any means whatever with the establishment, the goods, or the industrial or commercial activities, of a competitor. 
misappropriation to occur, the state of mind of the public as such is not relevant at all.

The concept of misappropriation can be illustrated very well with the example of the L'Oréal/Bellure-decision of the European Court of Justice. In that case, the ECJ ruled on the meaning of taking unfair advantage of the reputation of a trademark in article 5 (2) of the European Trademark Directive 89/1047 in a case on smell-a-likes.

The ECJ ruled "that the taking of unfair advantage of the distinctive character or the repute of a mark, within the meaning of that provision, does not require that there be a likelihood of confusion or a likelihood of detriment to the distinctive character or the repute of the mark or, more generally, to its proprietor" (emphasis added). In other words, no (proof of) misrepresentation is required. ${ }^{8}$

Moreover, the Court decided (in $\$ 49$ ) that:

- where a third party attempts,

- through the use of a sign similar to a mark with a reputation,

- to ride on the coat-tails of that mark in order to benefit from its power of attraction, its reputation and its prestige, and to exploit,

- without paying any financial compensation and

- without being required to make efforts of his own in that regard,

- the marketing effort expended by the proprietor of that mark in order to create and maintain the image of that mark,

- the advantage resulting from such use must be considered to be an advantage that has been unfairly taken of the distinctive character or the repute of that mark.

The L'Oréal/Bellure-decision has been criticised, among other things, for not taking into account (the importance of) countervailing principles such as freedom of information, and more specifically the need to inform consumers as to the nature of the product and freedom of comparative advertising. ${ }^{9}$ This criticism might well be legitimate; if one takes the position that it is not forbidden to make and sell a copy of a perfume, why would it then be forbidden to communicate to the public the fact that you are selling copies of a particular perfume? ${ }^{10}$

${ }^{7}$ First Council Directive 89/104/EEC of 21 December 1988 to approximate the laws of the Member States relating to trade marks, OJ 1989 L 40, p. 1.

${ }^{8}$ ECJ, case C-487/07, L'Oréal v. Bellure, [2009, not yet published in ECR].

${ }^{9}$ See for instance: Kur/Bently/Obly, Sweet Smells and a Sour Taste - The ECJ's L'Oréal decision (August 17, 2009). Max Planck Institute for Intellectual Property, Competition \& Tax Law Research Paper No. 09-12. Available at SSRN: http://ssrn.com/abstract=1492032.

10 In this respect, it should be noted that the much criticised Lancôme v. Kecofa-decision of the Dutch Supreme Court of 16 June 2006 (NJ 2006, 585) that perfumes can be protected by copyright, does make more sense from a systematic point of view. That it is not permitted to make or sell a copy of a (new and original) perfume sounds more straightforward than the 
But that is not the point here, as the importance of taking countervailing principles into account, is not denied here. ${ }^{11}$ The point is that the L'Oréal/Belluredecision demonstrates that the European Court of Justice is clearly lead by a basic moral conviction or feeling against parasitism.

It can be maintained that, in general, the concept of misappropriation in intellectual property amounts to the basic moral feeling that:

- where a third party attempts,

- through the use of an object $C$ similar to an object $B$

- to ride on the coat-tails of that object $B$ in order to benefit from its goodwill, and to exploit,

- without paying any financial compensation and

- without being required to make efforts of his own in that regard,

- the [...] effort expended by the proprietor of object $B$ in order to create and maintain goodwill of object $B$,

- the advantage resulting from such use must be considered to be an advantage that has been unfairly taken of object $B$.

Usually there will be harm or detriment to the proprietor, often there will be a likelihood of confusion on the part of the public, but that is not required for misappropriation to exist.

Another example of what is meant by misappropriation is the International News Service v. Associated Press decision ${ }^{12}$ of the US Supreme Court.

Associated Press used on the West Coast of the US all the news about the First World War which International News Service had collected at great expense through its correspondents in Europe and had published on the East Coast. Associated Press did not literally copy the news articles, but they copied all of the facts in those articles.

There is no copyright in news or news facts as such. "But one who gathers news at pains and expense, for the purpose of lucrative publication, may be said to have a quasi-property in the results of his enterprise as against a rival in the same business, and the appropriation of those results at the expense and to the damage of the one and for the profit of the other is unfair competition against which equity will afford relief”.

position that it is permitted to make and sell a copy of a (new and original) perfume, but that it is parasitic and amounts to unfair competition or trademark infringement to let it be known that you are selling such a copy.

11 A reference to such a countervailing principle might for instance be found in Recital 14, Sentence 6, of the Unfair Commercial Practices Directive (2005/29/EC): "It is not the intention of this Directive to reduce consumer choice by prohibiting the promotion of products which look similar to other products unless this similarity confuses consumers as to the commercial origin of the product and is therefore misleading".

12248 U.S. 215 (1918). 
It is all about misappropriation, unjust enrichment or: "You shall not reap where you have not sown". ${ }^{13}$ This is the core and 'gut feeling' of IP protection and unfair competition law. ${ }^{14}$

This is the emotional basis of patent law, copyright, trademark, design and database protection. This is the basis of the tort of passing off, the misappropriation doctrine and civil law protection against 'concurrence parasitaire', 'unlauteres wettbewerb' and 'slaafse nabootsing' (slavish imitation). It is the basic moral feeling against free riding and parasitism.

Amongst legal scholars, especially in the United Kingdom, there will probably be a lot of opposition to the very idea that there might be something like a basic moral feeling or principle against misappropriation because for them "imitation is the life blood of competition" 15 seems to be a much stronger moral feeling or principle. ${ }^{16}$ But even in the decision where this "imitation is the life blood of competition" quote comes from, it is recognised that a basic moral feeling against misappropriation exists:

"Hence at first glance it might seem intolerable that one manufacturer should be allowed to sponge on another by pirating the product of years of invention and development without license or recompense and reap the fruits sown by another. Morally and ethically such practices strike a discordant note. It cuts across the grain of justice to permit an intruder to profit not only by the efforts of another but at his expense as well". ${ }^{17}$

13 Although this sentence sounds biblical it is not, at least not in the meaning with which the sentence is used today. In the 'Parable of the Pounds' (Luke 19:11-27), the master gives some money to three servants and goes away. When he comes back two of the servants give back the money with profit and they are both generously rewarded. The third servant returns only the original sum, because has done nothing with the money and says: "I have kept it laid away in a piece of cloth. I was afraid of you, because you are a hard man. You take out what you did not put in and reap what you did not sow. The master answers: 'I will judge you by your own words, you wicked servant! You knew, did you, that I am a hard man, taking out what I did not put in, and reaping what I did not sow? Why then didn't you put my money on deposit, so that when I came back, I could have collected it with interest?'. He takes away all the money from the third servant and gives it to the servant which had made the most profit and makes the following curious capitalistic remark: 'I tell you that to everyone who has, more will be given, but as for the one who has nothing, even what he has will be taken away'. The same story can be found in Matthew 25:14-30. The lesson to be learned is that have to use our talents well, not that we should not harvest where we have not sown.

${ }^{14}$ Callmann, He who reaps where he has not sown: unjust enrichment in unfair competition, 55 Harv. L.R. 595-614 (1942) and: Kamperman Sanders, Unfair Competition Law (1997).

15 American Safety Table Company v. Schreiber 269 F.2d 255 (19 June 1959), http://open jurist.org/269/f2d/fn7.

${ }^{16}$ See for instance Spence, (1996) 112 LQR 472-498.

17 American Safety Table Company v. Schreiber 269 F.2d 255 (19 June 1959), http://open jurist.org/269/f2d/fn7, paras. 75 et seq. 
Then the Court continues:

"But this initial response to the problem has been curbed in deference to the greater public good. [...] For imitation is the life blood of competition. It is the unimpeded availability of substantially equivalent units that permits the normal operation of supply and demand to yield the fair price society must pay for a given commodity. [...] Unless such duplication is permitted, competition may be unduly curtailed with the possible resultant development of undesirable monopolistic conditions. The Congress, realizing such possibilities, has therefore confined and limited the rewards of originality to those situations and circumstances comprehended by our patent, copyright, and trade-mark laws. When these statutory frameworks are inapplicable, originality per se remains unprotected and often unrewarded. For these reasons and with these limitations the bare imitation of another's product, without more, is permissible. And this is true regardless of the fact that the courts have little sympathy for a wilful imitator".

And thus, at the end the same sentiment again: "the courts have little sympathy for a wilful imitator”.

There is also a strong belief among IP academics in general that the only justification for IP rights is the cool and rational concept that IP rights are a 'necessary evil' to "promote the Progress of Science and useful Arts, by securing for limited Times to Authors and Inventors the exclusive Right to their respective Writings and Discoveries". ${ }^{18}$

But in order to establish what is progress in the field of science, what is useful and what is art, in other words: what deserves protection and what scope of protection does it deserve, there will always be subjective criteria with a broad margin of appreciation which will have to be applied by the courts by balancing some kind of moral feelings against other important principles.

In this respect also there is no clear dividing line between IP protection and unfair competition law. The only difference is that with individual IP rights, such as patent, copyright, trademark, design and database protection, we pretend to have been able to come up with a balanced system of clearly defined criteria for: object, proprietor, requirements and threshold of protection, scope of protection, infringement, limitations and exceptions.

But as soon as we do not like the results, we either start messing up the system from the inside $(\mathrm{Opel} / \mathrm{Autec})^{19}$ or mess up the system from the outside $\left(\right.$ Magill) ${ }^{20}$, invent new IP or quasi-IP rights (EU Database-directive, US Misappropriation doctrine) or invoke or expand some tort or civil law protection against unlawful competition.

${ }_{18}$ Art. 1, Sec. 8, United States Constitution.

19 In ECJ, case C-48/05, Opel v. Autec, [2007] ECR I-1017, the ECJ introduced an extra requirement for trademark infringement under article 5.1(A) of the European trademark-directive 89/104/EEC, namely that use in question "is liable to affect the functions of the trade mark".

20 In Magill (ECJ, cases C-241/91 P and C-242/91 P [1995] ECR I-743) the ECJ ruled that under particular circumstances the exercise of copyright (in the weekly listings of television programmes) amounts to abuse of a dominant position. 
With unfair competition law we often admit that we are not able to come up with a balanced system and leave the whole matter tot the judge to determine.

At the same time, we as academics are slightly embarrassed by the fact that we are not able to come up with and maintain a balanced system of object, criteria and limitations which provides the legal certainty the public and the economy quite reasonably expect.

Therefore, we usually vigorously pretend that there is a clear and balanced system of individual IP rights which can cope with everything and that only in very exceptional circumstances unfair competition is needed to fill or correct the few and tiny remaining gaps. Unfair competition law should always be treated and applied with extreme caution, we usually say.

Within individual IP rights we also force the judge to apply his gut-feeling of misappropriation (and misrepresentation), and cover it up with the wording required by the most recent decision by the ECJ or national supreme court. And if a judge cannot solve an issue satisfactorily within the system of individual IP rights, he goes outside this system, to invoke or expand some tort, specific legislation against unfair competition or civil law protection against unlawful behaviour.

Inventive step, original creation, distinctive, significant difference, well known, individual character, substantial investment. Something worth protecting ? $^{21}$

"a fair protection for the patent proprietor" (EPC), “a substantial part” (Database), "not a different overall impression” (Design), "substantial similarity" (US), “striking similarity” (US), “improper appropriation” (US). All very subjective qualifications.

One experienced judge in The Netherlands identified the three P's of IP-infringement: Pretension, Parasite and Public.

Pretension: the claimant pretends to have done something that deserves protection. Is this pretense justified? Has he invented, created or invested enough to protect him against free-riding?

Parasite: Is the defendant a parasite? Can what the defendant does be considered free-riding? Has he made any contribution in terms of his own investment? Is there any objective need or justification for his copying, or is he just lazy and greedy?

${ }^{21}$ Patent lawyers might claim that the degree of subjectivity involved when assessing patentability or patent scope is much more restricted than in unfair competition law. But in defining the knowledge of "the average person skilled in the art" and in giving meaning to the term "inventive step" and by interpreting patent claims in accordance with "fair protection for the patent proprietor" they do also make many subjective normative choices culminating in what they deem to be worthy of protection in a particular case. 
Public: Is there the clearly undesirable side-effect of a risk of confusion on the part of the public? Or may the public be mislead in some other way?

"The prophecies of what the courts will do in fact" is probably the most important aspect of the law for most non-academics. The fact that "the courts have little sympathy for a wilful imitator" is also a reality. Basic moral feelings about misrepresentation and misappropriation shape sympathies and decisions, together with rational and abstract notions such as "the greater public good". And basic moral feelings often prevail. 


\title{
The Relationship between Intellectual Property Rights, Protection against Unfair Competition and Unfair Commercial Practices:
} A Lithuanian Perspective

\author{
Vytautas Mizaras
}

\section{Introduction}

A discussion of the relationship between the protection of intellectual property rights and the protection against unfair competition is not novel in legal theory and in the case-law. Art. 10bis (1) of the Paris Convention for the Protection of Industrial Property does not stipulate any requirements for the regulation of methods of protection against unfair competition. These methods of regulation have developed differently in different states. The approach taken by several major groups of states in this regard might be distinguished in terms of: ${ }^{1}$ (a) states where protection against unfair competition is not regulated separately, but is based on general rules of tort law (e.g., France, Netherlands) or common law (e.g., England); (b) states where protection against unfair competition is regulated by a special law or special legislative provisions contained in a broader law (e.g., a single law regulating only competition or a law regulating commercial activities generally also including the protection of consumer rights (e.g., Germany, Denmark, Sweden, Finland, Lithuania); and (c) states where the methods of regulation are mixed (e.g., United States).

The adoption of Directive 2005/29/EC of 11 May 2005 concerning unfair business-to-consumer commercial practices in the internal market ('Unfair Commercial Practices Directive') $)^{2}$ and its implementation in the member states has increased the relevance of another issue: the issue of the conflict of legal regulation in the areas of unfair commercial practices, protection against unfair

\footnotetext{
${ }^{1}$ See Kamperman Sanders, Unfair Competition Law: The Protection of Intellectual and Industrial Creativity (1997), pp. 55-77.

${ }^{2}$ Directive 2005/29/EC of the European Parliament and of the Council of 11 May 2005 concerning unfair business-to-consumer commercial practices in the internal market and amending Council Directive 84/450/EEC, Directives 97/7/EC, 98/27/EC, 2002/65/EC of the European Parliament and of the Council and Regulation (EC) No 2006/2004 of the European Parliament and of the Council (OJ L 149, 2005, pp. 22-39).
} 
competition and the protection of intellectual property rights. The Directive aims at full unification of the law, however, it does not create a common basis for the prohibition of unfair commercial practices. ${ }^{3}$ The application of the Directive is limited to relationships between business undertakings and consumers; thus, it does not apply to unfair commercial practices between business undertakings.

Currently, Lithuania is one of the states in which the protection against confusion in terms of the traditional law on unfair competition and the protection of consumers against confusion is regulated separately. Lithuania has implemented Directive 2005/29/EC by enacting a separate law, which will be further described below. This article focuses on an analysis of the approach taken in the Lithuanian law regarding conflicts in methods of legal regulation, identifying some problems which arise.

\section{The Legal Regulation of Intellectual Property Rights, Unfair Competition and Unfair Commercial Practices}

\section{General Remarks}

Intellectual Property Rights are regulated in Lithuania by separate laws (Copyright Law, Patent Law, Trade Mark Law, Design Law, etc.). The provisions on unfair competition law are embodied in Art.10bis of the Paris Convention for the Protection of Industrial Property ${ }^{4}$ and in other legislative acts. The legislative provisions that provide for the regulation of protection against unfair competition in Lithuania are regarded as part of the field of competition law. The Competition Law of the Republic of Lithuania, dated 23 March 1999, includes both provisions concerning the competition law system and rules against unfair competition. ${ }^{5}$ The integrated regulation of competition law and the protection against unfair competition does not take into account conceptual differences between the regulation of competition and the regulation of unfair competition. The differences are obvious: the rules of competition law prioritise the protection of the public interest and their implementation is ensured by control exercised by a competent public authority; whereas the legislative rules of protection against unfair competition laid down in Art. 16(1)(1) of the Competition Law, attribute priority to the protection of the individual interests of business

3 See Henning-Bodewig, Unfair Competition Law: European Union and Member States (2006), p. 58.

${ }^{4}$ Paris Convention for the Protection of Industrial Property dated 20 March 1883, which entered into effect on 22 May 1994 in Lithuania.

${ }^{5}$ For more see Mizaras, Unfair Competition Law in the Baltic States, in: Hilty/HenningBodewig (eds.), Law Against Unfair Competition: Towards a New Paradigm in Europe? (2007), p. 249. 
undertakings and are normally enforced by private claims made by business undertakings. Due to these differences, integrated regulation of these areas is not typical in the law of Western states. Rather, it is only common in Eastern and Central European states. ${ }^{6}$ This accords with Dr. Bakardjieva-Engelbrekt's opinion that an integrated regulation of competition and unfair competition in Eastern and Central European states is predetermined by the historical context in which the first competition laws were enacted in this region, i.e. by the necessity of adapting legal regulation to new economic conditions, which has led to a rather hasty adoption of foreign models of legal regulation.

The Lithuanian competition acts contain specific provisions concerning the exploitation of another's achievements, the likelihood of confusion and imitation. Art. 16 (2) No. 1 and No. 5 the Lithuanian Competition Law prohibits the unauthorised use of a sign that is identical or similar to another enterprise's registered trademark, a famous trademark, an older trademark, name or other distinguishing sign, if the use of this sign: (i) means that there is a likelihood of confusion for the public with this enterprise or its activity; or (ii) impairs the distinctive character of the older trademark or sign; or (iii) unfairly exploits or impairs the reputation of the older trademark or the reputation of this enterprise. Unauthorised imitations of the products or product packaging of another enterprise in which the external shape, packaging colour or other distinctive feature is imitated are prohibited if such imitations lead to a likelihood of confusion or if the reputation of the other enterprise has been exploited.

On 21 December 2007, the Law on the Prohibition of Unfair Business-toConsumer Commercial Practices ${ }^{7}$ was adopted to protect consumers from misleading commercial practices. This law implements the Directive on Unfair Commercial Practices 2005/29/EC. The Directive on Unfair Commercial Practices is the first EU legal act aimed at fully harmonising the law of unfair competition in cases when unfair practices violate the economic interests of consumers (see Art. 1). Pursuant to Art. 5(2) of the Directive, unfair commercial practice is defined as commercial practice that materially distorts or is likely to materially distort economic behaviour of the consumer with regard to the product. ${ }^{8} \mathrm{Un}-$ fair commercial practices include, inter alia, a commercial practice that causes or is likely to cause the average consumer to take a transactional decision that he would not have otherwise taken. Such practices also include any marketing

${ }^{6}$ See Bakardjieva Engelbrekt, An End to Fragmentation? The Unfair Commercial Practices Directive from the Perspective of the New Member States from Central and Eastern Europe, in: Weatherill/Bernitz (eds.), The Regulation of Unfair Commercial Practices under EC Directive 2005/29 (2007), p. 62.

7 Valstybès žinios (Official Gazette), 2008, No. 6-212.

8 Art. 5 (2)(b) of the Directive: A commercial practice shall be unfair if [...] it materially distorts or is likely to materially distort the economic behaviour with regard to the product of the average consumer whom it reaches or to whom it is addressed, or of the average member of the group when a commercial practice is directed to a particular group of consumers. 
which creates confusion with other products, trade marks, trade names or other distinguishing marks of a competitor (Art. 6 (2)(a) of the Directive). ${ }^{9}$ Thus, the Directive ensures a certain standard of information that should be provided to consumers in the course of commercial activities.

\section{Protected Interests}

A comparison between the provisions of the Directive on Unfair Commercial Practices and of the Law on Prohibition of Unfair Business-to-Consumer Commercial Practices with the rule laid down in Art. 16(1) of the Lithuanian Competition Law makes it possible to state that the provisions of the Competition Law do not make it necessary to identify whether a misleading practice would materially distort the economic behaviour of consumers, i.e. whether they would buy competitor's products, which they would not have purchased otherwise. Thus, the provisions of Art.16(1) of the Competition Law set a standard for confusion which is easier to prove in comparison to the standard established in the Directive on Unfair Commercial Practices and in the Law. Given the differing standards for confusion, it is necessary to analyse an interrelationship between the aforementioned provisions.

Recital 6 of the Directive 2005/29/EC neither covers nor affects national laws on unfair commercial practices which only harm competitors' economic interests or which relate to transactions between traders. This provision does not reveal whether the Directive covers prohibitions that prioritise the protection of competitors, but also indirectly protects the economic interests of consumers, as is case of Art. 16(1) of the Competition Law. Art. 16(1) of the Competition Law provides for two different legislative provisions to this effect. The first part of this provision protects the economic interests of the holder of the earlier distinctive mark, however, it also indirectly protects consumer interests against being misled. The second part is exclusively designated for the protection of the interests of business undertakings that use marks with a reputation.

The European Commission Green Paper states that practices violating the interests of competitors and consumers shall be covered by the scope of regulation of the Directive to the extent that they are related to consumers. ${ }^{10}$ From this explanation, it can be concluded that the member states have discretion in regulating the likelihood of confusion caused by unfair practices with a view to protecting the interests of competitors ${ }^{11}$ and that the provisions implementing the Directive should be applied only when a certain practice is sought to be pro-

9 See Collins, et al., The Forthcoming EC Directive on Unfair Commercial Practices (2004), pp. 187-223.

10 Howells/Miklitz/Wilhelmsson, European Fair Trading Law: The Unfair Commercial Practices Directive (2006), p. 69.

$11[\ldots]$ taking full account of the principle of subsidiarity, Member States will continue to 
hibited on grounds of the protection of consumer interests. Consequently, the provisions of Art. 16(1) of the Competition Law can be further interpreted independently of the provisions of the Directive. In cases where unfair competition practices are sought to be prohibited due to the detriment they might cause to general consumer interests, the provisions of the Law on Prohibition of Unfair Business-to-Consumer Commercial Practices that implement the Directive in Lithuania must be applied.

It is obvious that sometimes unfair practices that infringe the interests of both the competitor and the consumers might fall within the scope of both legal acts, that is, the Competition Law and the Law on Prohibition of Unfair Business-to-Consumer Commercial Practices. However, the "overlapping" of these provisions is only occasional. The consumer is involved in the law of unfair competition not as a subject with protected rights, but as an indicator to help ascertain whether the earlier rights of another business undertaking have been breached (as the awareness of the consumer is used to determine the likelihood of confusion). In this case what is relevant from a legal perspective, is not the existing or imminent damage to consumers as a result of being confused, but the present or potential damage to the competitor, manifest in the unfair procurement of the business of the consumers of the other undertaking, damage to its reputation, etc. ${ }^{12}$ On the other hand, the Directive places emphasis on the collective protection of consumers against unfair commercial practices. ${ }^{13}$ It lays down the conditions upon which unfair commercial practices can be prohibited on the grounds of general consumer protection, irrespective of the claims of individual consumers who have suffered from relevant practices. It is this element that predetermines the criterion for unfairness which is only linked to practices that have or can have a decisive influence on consumer choice: the benchmark of unfairness must be sufficiently high to justify interference with commercial practices for the benefit of the public interest even in the absence of any claim made by a specific person who has suffered or is exposed to actual damage as a result of such practices.

The differences between the mechanisms for the protection of rights and the sanctions used for violations of the provisions on unfair competition and unfair commercial practices should be noted. In the case of unfair competition, civil remedies are applied and the dispute is examined in civil proceedings initiated by a person seeking to protect his private interests. Pursuant to Art. 17(4) of the Competition Law, complaints about unfair competition practices should

be able to regulate such practices, in conformity with Community law, if they choose to do so [...] (Recital 6 of the Directive).

${ }^{12}$ For more detail see Alpa, Rules on Competition and Fair Trading, in: Collins, et al, The Forthcoming EC Directive on Unfair Commercial Practices (2004), p. 96.

13 The Recitals of the Directive note that it is without prejudice to individual actions brought by those who have been harmed by an unfair commercial practice. 
be brought as private actions before the court. The Competition Council may examine such practices only when these acts violate the interests of the majority of undertakings or consumers. ${ }^{14}$ Meanwhile, regulation under the Directive on Unfair Commercial Practices is mainly in terms of administrative remedies and procedures of an administrative nature initiated on the grounds of public interest, the outcomes of which can be reviewed by an administrative court. In the regulation of unfair commercial practices it is also possible to use mechanisms designated for the protection of the consumer including supervision by public authorities and consumer organisations' right to bring actions. In dealing with applications by commercial undertakings to commence investigations under Art. 16 (1) of the Competition Law on the ground that damage has been caused to the interests of many undertakings and consumers (Art. 17 (4) of the Competition Law), the Lithuanian Competition Council interprets the latter condition narrowly and applies the higher gauge to the test of consumer confusion, which is referred to in the Directive and which substantially distorts the economic behaviour of consumers.

According to the Lithuanian Competition Council, disputes regarding the unauthorised use of a mark identical or similar to the name, registered trade mark or unregistered well-known trade mark or any other reference having a distinguishing feature of another undertaking, if this causes or is likely to cause, confusion with that undertaking or its business activities, or where undue advantage is sought to be taken of the reputation of that undertaking, and other disputes regarding acts of unfair competition are dealt with by courts of general jurisdiction. The Competition Council investigates acts of unfair competition only in cases where these acts violate the interests of the majority of undertakings or consumers, by determining their economic behaviour or by causing changes in this behaviour. ${ }^{15}$ This approach makes it apparent that the Lithuanian Competition Council applies the consumer confusion standard defined in the Directive 2005/29/EC to the infringement of consumer interests and treats this separately from the content of Art. 16(1) of the Competition Law. The Court agrees with this position and has noted that the aim of the Competition Council is to protect the public interest (the freedom of fair competition). The Council is obligated to investigate acts of unfair competition only when

14 In the case where the organisations representing consumer interests apply to the court regarding an infringement of Art. 16(1)(1) of the Competition Law (Art. 17(2) of the Competition Law) or when certain acts of unfair competition are investigated by the Competition Council on the grounds that they violate the interests of consumers (Art. 17(4) of the Competition Law), the standard referred to in the Directive and the Law on Prohibition of Unfair Business-to-Consumer Commercial Practices and based on the public and consumer interest should presumably be applied.

${ }^{15}$ See the judgment of the Vilnius District Administrative Court, 31 January, 2008, case No I-2340-426/2008. 
they violate the interests of the majority of undertakings and consumers and not just individual interests. ${ }^{16}$

It follows from the foregoing explanation that the harmonisation of consumer protection in the Directive on Unfair Commercial Practices does not affect the interpretation of the provisions of Art. 16(1) of the Competition Law and its application in civil disputes between undertakings. Art. 16 (2) of the Lithuanian Competition Law remains directed towards B2B relationships. It does not require proof that the practices it covers also directly breach consumer interests or interests broader than the interests of individual consumers. On the other hand, an infringement of this Law may, at the same time, mean a breach of the rights of consumers; although, as has been mentioned, these are not the principal interests protected by this Law. Lithuanian judicial practice emphasizes that honest competition not only fosters freedom of business activity but also ensures the maintenance of the interests and normal business activities of commercial enterprises. ${ }^{17}$ In addition, it safeguards consumer interests, particularly where this is combined with legal provisions guaranteeing the origin and quality of the goods. ${ }^{18}$ Nevertheless, after the Law on Unfair Commercial Practices comes into force there will be turn towards focussing on safeguarding the interests of consumers.

\section{The Relationship between the Protection of Separate Rights and Interests: Intellectual Property Rights, Unfair Competition and Unfair Commercial Practices}

\section{General Overview}

Analysis of the legal theory and the case-law of other countries shows that different positions predominate with relation to the interpretation of the relationship (conflict) between the protection of intellectual property rights and unfair competition. For example, in Germany, although there is no unanimous opinion on this relationship, two major concepts can be distinguished. A prevailing consideration is the so-called principle of the supremacy of intellectual property rights over the protection against unfair competition (in German -

\footnotetext{
16 Ibid.

17 See the judgment of the Supreme Court of the Republic of Lithuania, 25 April 2005, Case No. 3K-3-259/2005 - UAB Ekspedita v. UAB Chemtransa.

18 See the judgment of the Supreme Court of the Republic of Lithuania, 23 March 2005, Case No. 3K-3-150/2005 - Unilever N.V. v. UAB Varta.
} 
Vorrangthese).${ }^{19}$ The second concept is built on the idea of their mutual equality (in German - Gleichrangprinzip). ${ }^{20}$

The French legal theory and case-law frequently treats the relationship between the provisions of intellectual property law and unfair competition law as a relationship between action en contrefaçon and action en concurrence déloyale. Most commonly reference is made to actions regarding violations in general terms, without making a differentiation in the analysis in terms of the separate objects of intellectual property. On the other hand, the relationship between the different groups to be protected against unfair competition on the basis of confusion (risque de confusion) and parasitism (parasitisme) is analysed on a generalised basis. ${ }^{21}$ The French case-law and the legal theory differentiate between two areas: concurrence déloyale and concurrence parasitaire. The first area deals with competition distortions; the second safeguards certain achievements of the claimant against the respondent's acts, which derive unfair advantage from these achievements. ${ }^{22}$

The relationship between the concepts of intellectual property and the protection against unfair competition in Swiss law have a common characteristic: in principle, none of them favours the cumulative application of the provisions of intellectual property and unfair competition laws.

UK law is known to include the tort of passing off. This cause of action, in the same way as the protection against unfair competition under Art. 1382 of the French Civil Code, is designed to protect the private interest of business undertakings. The field of protection against unfair competition, which centres on the protection of consumers and the public interest, is also regulated by special individual laws in the UK whose enforcement is delegated to competent public authorities. ${ }^{23}$

19 See, for instance, Obly, Klemmbausteine im Wandel der Zeit - ein Plädoyer für eine strikte Subsidiarität des UWG-Nachahmungsschutzes, in: Festschrift Eike Ullmann (2006), 795-812; Henning-Bodewig, Relevanz der Irreführung, UWG-Nachahmungsschutz und die Abgrenzung Lauterkeitsrecht/IP-Rechte, GRUR Int 2007, 986; Stieper, Das Verhältnis von Immaterialgüterrechtsschutz und Nachahmungsschutz nach neuem UWG, WRP 2006, 291, 298.

20 See, for instance, Köhler, Das Verhältnis des Wettbewerbsrechts zum Recht des geistigen Eigentums - Zur Notwendigkeit einer Neubestimmung auf Grund der Richtlinie über unlautere Geschäftspraktiken, GRUR 2007, 548, 550; Henning-Bodewig (supra, note 19), p. 990; Obly, Designschutz im Spannungsfeld von Geschmacksmuster-, Kennzeichen- und Lauterkeitsrecht, GRUR 2007, 731, 738.

${ }^{21}$ See Schmidt-Szalewski, Der Unterschied zwischen der Klage wegen Verletzung gewerblicher Schutzrechte und der Wettbewerbsklage in der französischen Rechtsprechung, GRUR Int. 1997, 1.

${ }^{22}$ See more Kamperman Sanders, Unfair Competition Law: The Protection of Intellectual and Industrial Creativity (1997), pp. 24-31.

23 See WIPO, Protection Against Unfair Competition: Analysis of the Present World Situation (1994), p. 15. 
Thus, further analysis shows that the system of legal regulation of the protection against unfair competition and commercial practices in Lithuania is not identical to the regulatory framework on this matter in Germany, France or the UK. The following chapter covers the Lithuanian legislative approach to the contested issues.

\section{The Lithuanian Viewpoint}

The Lithuanian law provides for protection against unfair competition in an independent (autonomous) set of rules. That is, not every act of unfair competition will entail an infringement of intellectual property rights. Similarly, not every infringement of intellectual property rights indicates that there is unfair competition present. Each legal wrong must be assessed separately, so that it will only be possible to state that a person's rights have been infringed by a legal wrong, if the elements which characterise the relevant legal wrong can be identified. ${ }^{24}$

It follows that this position does not favour the aforementioned "priority" concept. In other words, the relationship between intellectual property law and the protection from unfair competition should not be treated identically to the relationship between special and general legislative provisions. Intellectual property law and the law of protection against unfair competition are different in terms of their specific provisions, their intended goal in regulating certain relationships, and in the methods of protection which they envisage. That is why they are autonomous, independent and on a par with each other. In cases where the same acts infringe both intellectual property rights and the prohibition on unfair competition, the legislative provisions of intellectual property and the protection from unfair competition should be applied cumulatively. This cumulative application should not lead to the offender being punished two times, i.e. the amount of damages ordered should not exceed the damages caused to the claimant by the acts taken together. The autonomy of the law of protection against unfair competition is also important because it can be used as an instrument of protection against unfair competition, which manifests itself in a violation of intellectual property rights, not only by the holder of such rights, but also by any third party whose interests are impaired by such acts.

Nevertheless, a conception of intellectual property law and the protection against unfair competition as fully autonomous regimes should not be held absolutely unconditionally.

If we were to recognise the protection against unfair competition as absolutely independent from intellectual property law, the question would arise as

${ }^{24}$ Mizaras, Autorių teisè (Copyright Law), Vol. 1 (2008), p. 76. 
to whether the application of the rules of protection against unfair competition would be subject to any limits and, if so, what would be the extent of these limits. For example, how to answer the question of whether copying a book, which is not protected by copyright (because the work does not satisfy the requirements set for this kind of protection) is unfair competition. If the answer is yes, then it seems that recourse to protection against unfair competition would make it possible to avoid the prerequisites for protection set out by intellectual property law, in this case, copyright. It goes without saying that in this case any "avoiding" is conditional - protection against unfair competition would in no way grant the exclusive rights that copyright law does. Nevertheless, protection against unfair competition would make it possible for the claimant to prohibit copying of the book, in order to achieve the same outcome that copyright's main exclusive property rights do, that is, the ability to allow or prohibit any reproduction of the work. Or can an imitation of the product, which performs a solely technical function and which is not protected by patent law due to the lack of inventive step, be held to constitute unfair competition? In this case an answer can certainly be found in Art. 16 (1)(5) of the Lithuanian Competition Law which stipulates that imitating a product with a view to achieving certain functional properties is not unfair competition.

The legal theory and case-law on protection against unfair competition of other countries unambiguously emphasises that a prohibition on the imitation of such objects would be incompatible with the terms and limits defined for the protection of inventions by patent law. For this reason, it is already possible to state that the rules of patent law show a clear criterion for setting and interpreting the scope of protection against unfair competition. This, in turn, allows for a conclusion that protection against unfair competition per se cannot be fully independent from intellectual property law.

The authors supporting the concept of the subsidiary application of protection against unfair competition and the principle of supremacy of intellectual property quite rightly maintain that the material formal conditions of protection and the limits of the term of protection must be respected. The outcome should not be that that which is allowed by one law (intellectual property law) is, in principle, prohibited by other laws (the law of protection against unfair competition). However, in my opinion, a theoretical shortcoming of this interpretation of the conflict is that these concepts fail to explain the grounds upon which intellectual property law is given priority, thus, preventing a cumulative application of the provisions of this law and the law on protection against unfair competition when the factual circumstances are the same. This question is partly answered by Professor Ohly who notes that there is no relationship between general and special provisions of law in these cases. Professor Ohly claims that when a certain object is extensively regulated by the provisions of one specific law, the legal theory usually refers to other provisions as 
"subsidiary due to extensive regulation". ${ }^{25}$ However, the fact that intellectual property law does not afford protection in a specific case should be treated separately from the substantially different issue of whether the lack of protection means that the legislator did not want to prohibit the use of the relevant object in general (e.g., the fact that the mark has not been registered as a trade mark means that the protection established by trade mark law does not apply to it and this should not automatically imply that the legislator's intention was that such marks ought not to be protected in general).

None of the provisions of law are autonomous. Each of them should be created, interpreted and applied, not in isolation, but taking into account other legislative provisions so that internal conflicts within the legal system can be avoided. Nevertheless, it can be the case that the same factual circumstances fall within the scope of several legislative provisions. In such cases, depending on the interrelation between the legal consequences of the application of these provisions, the legal theory lays down rules for dealing with such conflicts. When the subsidiarity approach to protection against unfair competition is followed, the application of universal rules to resolve the conflict of legislative provisions can be avoided. Protection against unfair competition is applicable if it is impossible to protect the relevant interests by other provisions of the law. Meanwhile, the rules which regulate conflicts of legislative provisions facilitate and, at the same time, hinder the interpretation of the relationship between the provisions of intellectual property law and the law of protection against unfair competition, as autonomous in respect of each other. If a specific act is an element of the infringement of both intellectual property rights and the prohibition on acts of unfair competition, the issue of cumulative competition becomes relevant. Nevertheless, in terms of protection against unfair competition, the literature fails to elaborate on one aspect, which needs to be particularly emphasised.

Protection against unfair competition is based on the condition, which is difficult to concretize and is, at the same time, rather flexible - contrariness to good faith practice and good business dealings. Art. 16 (1) of the Lithuanian Competition Law lays down a general provision prohibiting any acts contrary to honest business practices and customs, if such acts might be detrimental to the competitive potential of another undertaking. This general rule is very close to the general provisions of the Swiss and German Unfair Competition Laws. According to these provisions, unfair competition can be established not only on the grounds of dishonesty. Its negative effect on competition should be also taken into account.

This condition of "honest commercial activities and good customs" can be considered a "filter" that would make it possible to assess the scope of protection defined by intellectual property law when deciding whether some acts are

${ }^{25}$ Obly (supra, note 20). 
to be considered as constituting an act of unfair competition. It would justify a cumulative application of legislative provisions. In this case, the cumulative application of legislative provisions would not be prevented by the prerequisite that acts negatively impact upon commercial activities, because the acts violating intellectual property rights cannot be considered honest in their nature. The filter of "honest economic activities and good customs" could also be used in order to determine if it is possible to apply protection against unfair competition and in order to answer the following questions: (a) whether the legislator has intentionally omitted some objects from the laws of intellectual property, or (b) has limited breaches of the rights thereunder in certain factual circumstances. In the first case, protection against unfair competition would be also inapplicable for the same reasons: if some objects have been indirectly and intentionally set aside by the legislator for public use, their use (e.g., imitation) cannot be "dishonest". The application of the protection against unfair competition to the direct protection of objects against imitation in exceptional cases would not be incompatible with the latter approach, if it were established that their protection was not provided for under intellectual property law not because the legislative intention was to have the unrestricted free use of these objects, but as merely a gap in the protection resulting from the inadequate response of the legislator to scientific, technical and other developments. In the second case, a proper interpretation would make it possible to prevent the circumvention of mandatory protection relying on the grounds provided for by the legislative provisions on the protection against unfair competition when protection is allowed only if there are additional circumstances, which are not covered by intellectual property law and which prove dishonesty.

In my view, such an interpretation would minimise the need for discussions on the relationship between intellectual property law and the protection against unfair competition, as between special and general legislative provisions. It would likewise enable the concepts of subsidiarity and supremacy to be set aside taking from them only what is most important - the need to take the scope defined by intellectual property law into consideration. On the other hand, such an interpretation could be implemented successfully, only if the courts are in the position to interpret the laws of intellectual property adequately and to identify when the fact that a certain object is not protected by intellectual property (due to material, formal or time-related reasons) should be understood as the legislator's intention to leave the object for free use, which cannot be circumvented by applying protection against unfair competition. 


\section{Unfair Competition and Unfair Commercial Practices}

It has been mentioned that the protection against unfair competition and the protection against unfair commercial practices safeguard different interests. The differences between the interests protected by these laws also influence the treatment of their mutual conflicts. The law on the protection against unfair competition safeguards consumer interests and is described in the legal theory as a separate area of law, which is not subordinate to industrial property law ${ }^{26}$. Since the prohibition on unfair commercial practices serves consumer protection and public interests, its rules are imperative and should be given priority over the provisions of industrial property law and traditional unfair competition law. This means that misleading consumers in circumstances that constitute all the elements of unfair commercial practices cannot be justified even by the possession of exclusive rights to the relevant trade mark or the trade name of the undertaking.

Thus, the provisions of the protection against unfair commercial practices are imperative provisions designed to protect the public interest (of consumers). They should have priority over both the provisions of intellectual property law and the provisions of the traditional law on the protection against unfair competition. For example, if the use of a registered trade mark amounts to an unfair commercial practice within the meaning of the Law on Prohibition of Unfair Business-to-Consumer Commercial Practices, it could be prohibited from being used in a certain way, irrespective of whether its registration is still valid.

However, the difference in the scope of protected interests leads to different understandings of confusion in terms of the use of conflicting intellectual property objects (e.g., trade marks). The Lithuanian Law on Trade Marks regulates the protection against confusion. The likelihood of confusion in the case of trade marks is the furthest from actual confusion, because the ascertainment of the likelihood of confusion follows the details of the trade mark's registration rather than the circumstances of the actual usage of the mark. In the case of protection against unfair competition, the likelihood of confusion is determined in light of a broader range of factual circumstances. And in case of unfair commercial practices, the likelihood of confusion is even narrower, as confusion which is detrimental from the perspective of the public interest has to be present, i.e. confusion that substantially distorts or is likely to distort the economic behaviour of the average consumer in respect of the relevant product.

Article 16 of the Lithuanian Competition Law covers only those confusing acts, which should be considered unfair from the perspective of the protection of competitors' interests. Art. 16(1)(1) of the Competition Law provides for the protection against the unauthorised use of commercial marks, when this can

${ }^{26}$ See Henning-Bodewig (supra, note 19), p. 986. 
cause, or is likely to cause, confusion or otherwise be detrimental to the interests of the earlier holder of similar marks. Such practices are attributed to acts amounting to unfair competition in terms of the protection of the competitors' interests and are in compliance with Art. 10bis(3)(1) of the Paris Convention. Acts of unfair competition that violate the interests of consumers and the general public are regulated in Lithuania not as unfair commercial practices under Art. 16 of the Competition Law, but by the provisions of the law aimed at protecting consumers and the public interest, the most important being the Law on Prohibition of Unfair Business-to-Consumer Commercial Practices.

\section{Conclusion}

In summary, the following conclusions can be made.

With regard to the relationship between the protection against unfair competition and the protection of intellectual property rights, the author of this article favours the autonomy of these laws and the possibility of their cumulative application. Nevertheless, the cumulative application of the protection against unfair competition and intellectual property law is subject to constraints. In relevant cases legislative intentions must be taken into account: i.e. whether in drafting the intellectual property law some cases or areas where the use of certain objects must be unrestricted have been intentionally omitted. Such an assessment could make use of the filter of "honest commercial practices and good customs".

With regard to the application of the provisions on unfair business-to-consumer commercial practices, it can be maintained that the principle of priority of these provisions should be followed. However, it must be born in mind that this legal regime serves the protection of consumers' interests, as the public interest, and, consequently, calls for a different benchmark for determining confusion in respect of the economic behaviour of consumers compared to that used for the protection of intellectual property rights and in traditional cases involving the protection against unfair competition.

In revisiting the Directive 2005/29/EC it was mentioned that this Directive did not create any general grounds for the prohibition of unfair commercial practices. Besides, the Directive does not replace or systemise other directives with relevance to the unification of the law of unfair competition and has no superiority over the directives that set forth the special regulation of separate aspects of unfair commercial practices (Art. 3 (4): <...> all other Community rules governing specific aspects of unfair commercial practices will prevail). Furthermore, the application of the Directive is limited to business-to-consumer relationships and does not apply to unfair commercial practices between business undertakings. In this light, it can be claimed that the framework of the so-called EU secondary legislation remains fragmentary in terms of how it regulates 
unfair commercial practices so that conflicts are likely to occur not only between EU legal acts, but also between the national legal acts implementing these acts. This does not lead to adequate legal certainty. Therefore, whether the EU should undertake general unification and/or systematisation efforts in respect of the standards (principles) in the protection against unfair competition or unfair commercial practices ought to be discussed.

As regards the possibility of Common Principles of European Intellectual Property Law, my view is that the following conceptual approach should be followed. Firstly, the principles should be built on the underlying values or, in other words, on the fundamental provisions of the relevant legal instrument (in this case, of intellectual property law as part of private law). Secondly, the principles are the values that underpin the creation, interpretation and application of legislative provisions. Consequently, reference should be made only to the core principles, which define the essence of intellectual property law as private legal relationships, and which are, in principle, common to all jurisdictions of the European Union. This should be determined bearing in mind that none of the principles are absolute and that their implementation is subject to certain limits. Thirdly, a definition of the principles to be followed in resolving conflicts of intellectual property law and other related areas is necessary. The "principles" should also include model rules that ought to be broad enough to suit different situations and to adequately meet the needs, which are intended to be satisfied by the potential project of "The Principles". 



\section{List of Authors}

\section{Steven Anderman}

Professor of Law Emeritus, University of Essex; Visiting Professor at the University of Stockholm

\section{Gerhard Dannemann}

Prof. Dr. jur., M.A. (Oxon), Chair for English Law, British Economy and Politics, Humboldt University Berlin

\section{Christophe Geiger}

Dr. jur., Associate Professor, General Director and Director of the Research Department of the Centre for International Intellectual Property Studies (CEIPI), University of Strasbourg; senior researcher, Max Planck Institute for Intellectual Property and Competition Law, Munich

\section{Annette Kur}

Prof. Dr. jur., senior researcher at the Max Planck Institute for Intellectual Property and Competition Law, Munich

\section{Matthias Leistner}

Prof. Dr. jur., LL.M. (Cantab), Chair for Civil Law, Intellectual Property Law and Competition Law, University of Bonn

\section{Vytautas Mizaras}

Prof. Dr. jur., LL.M. (Frankfurt/Main), Head of the Department of Private Law, Faculty of Law, Vilnius University

\section{Alberto Musso}

Prof. Dr. jur., Professor of Commercial Law and Vice-Dean of the Faculty of Law, University of Bologna 
Igor B. Nestoruk

Dr. jur., M.J.C. (Bonn), Assistant Professor (adiunkt) Adam-Mickiewicz University Poznań

Marcus Norrgaird

Dr. jur., Professor of Intellectual Property Law, Hanken School of Economics, Helsinki

Ansgar Obly

Prof. Dr. jur., LL.M. (Cantab), Chair for Civil Law and Intellectual Property Law at the University of Bayreuth; Visiting Professor at the University of Oxford

Jean-Luc Piotraut

Prof. Dr. jur., Faculté de Droit, Economie, Administration, Université Paul Verlaine-Metz

Jens Schovsbo

Prof. Dr. jur., Ph.D., University of Copenhagen, Centre for Information and Innovation Law

Dirk Visser

Prof. Dr. jur., Professor of Intellectual Property, Leiden University, advocaat (attorney), Amsterdam 